\title{
COBERTURA FLORESTAL E CUSTO DO TRATAMENTO DE ÁGUAS EM BACIAS HIDROGRÁFICAS DE ABASTECIMENTO PÚBLICO: CASO DO MANANCIAL DO MUNICÍPIO DE PIRACICABA
}

\section{LÚCIA VIDOR DE SOUSA REIS}

\author{
Tese apresentada à Escola Superior de \\ Agricultura "Luiz de Queiroz", Universidade de São \\ Paulo, para obtenção do titulo de Doutor em \\ Recursos Florestais, com opção em Conservação de \\ Ecossistemas Florestais
}

P I R A C I C A B A

Estado de São Paulo - Brasil

Agosto- 2004 


\section{COBERTURA FLORESTAL E CUSTO DO TRATAMENTO DE ÁGUAS EM BACIAS HIDROGRÁFICAS DE ABASTECIMENTO PÚBLICO: CASO DO MANANCIAL DO MUNICÍPIO DE PIRACICABA}

\section{LÚCIA VIDOR DE SOUSA REIS}

Engenheira Sanitarista e Civil

Orientador: Prof. Dr. WALTER DE PAULA LIMA

Tese apresentada à Escola Superior de Agricultura “Luiz de Queiroz”, Universidade de São Paulo, para obtenção do titulo de Doutor em Recursos Florestais, com opção em Conservação de Ecossistemas Florestais

P I R A C I C A B A

Estado de São Paulo - Brasil

Agosto - 2004 


\section{Dados Internacionais de Catalogação na Publicação (CIP) DIVISÃO DE BIBLIOTECA E DOCUMENTAÇÃO - ESALQ/USP}

Reis, Lúcia Vidor de Sousa

Cobertura florestal e custo do tratamento de águas em bacias hidrográficas de abastecimento público : caso do manancial do município de Piracicaba / Lúcia Vidor de Sousa Reis. - - Piracicaba, 2004.

215 p. : il.

Tese (doutorado) - Escola Superior de Agricultura Luiz de Queiroz, 2004.

Bibliografia.

1. Abastecimento de água 2. Bacia hidrográfica 3. Cobertura vegetal 4. Mananciais 5. Piracicaba 6. Proteção ambiental 7. Recursos hídricos 8 . Tratamento de água - Custos I. Título

CDD 551.483 
À minha mãe Elisabeth que me ensinou a viver e persistir.

Aos meus filhos Inaê e Ory, pelos momentos de ausência e porque são luzinhas na minha vida.

Ao meu pai Flávio pela imensa colaboração e estímulos pra ficar craque.

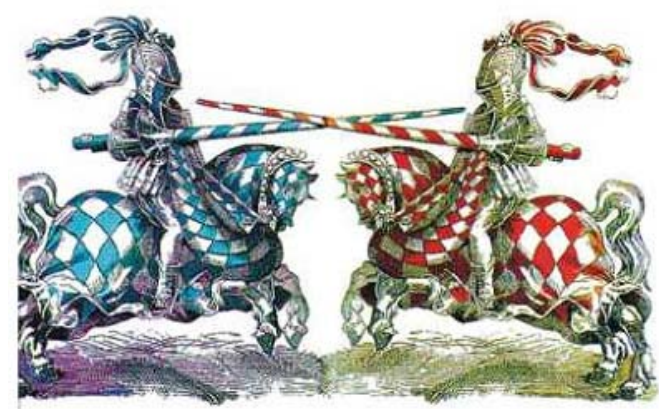

“Antigamente os homens faziam a guerra para conquistar terras...” Ziraldo

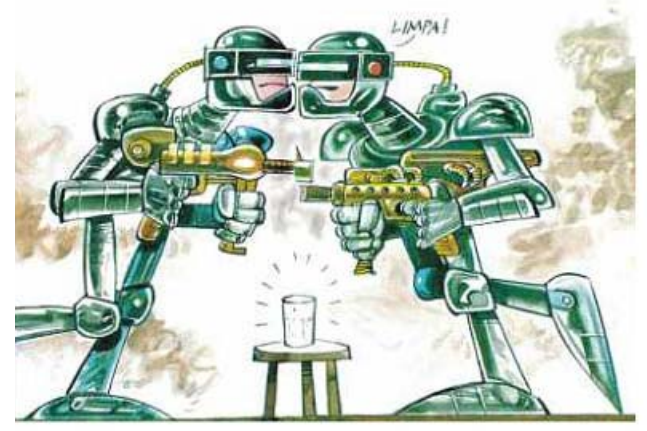

"Do jeito que a coisa vai, não demora muito e os homens vão guerrear por um pouquinho de água...” Ziraldo 


\section{AGRADECIMENTOS}

Ao Professor Dr. Walter de Paula Lima por sua orientação, abertura e paciência na condução da pesquisa e por me proporcionar uma nova visão sobre o conhecimento;

À Dra. Maria José Zakia por sua co-orientação, pelo consolo incondicional, pelo incentivo diante das dificuldades, pela amizade preciosa, pela delícia de conviver com alguém tão especial e pelo ensinamento de que profissionalismo e descontração podem caminhar juntos;

Ao Departamento de Ciências Florestais, que me possibilitou a realização do curso de pós-graduação;

Ao Laboratório de Hidrologia, em especial à Paula pela ajuda prestada em muitos momentos e pela solidariedade; ao Fernando pelas conversas;

À CETESB pela oportunidade de realizar esta capacitação e em especial aos meus colegas da Agência Ambiental da CETESB de Piracicaba;

Ao DPT do SEMAE, na figura do Tecnólogo José Maria, que não poupou esforços para me atender sempre com tanta presteza e à Elaine pelas informações;

À SANASA, na figura dos Eng ${ }^{\circ}$ S Paulo e Sidnei, pelas informações prestadas;

À SABESP pelas informações prestadas;

Ao DAAE de Rio Claro na figura do eng ${ }^{\circ}$ Ourival pelas informações prestadas; 
Ao novo amigo Dr. Dirceu Pagoto Stein pela valiosa colaboração, incentivo e mostra de competência e integridade profissional;

Ao Professor Dr. Dálcio Caron por contribuir de alguma maneira com minha entrada no caminho da pós graduação e pela leitura e contribuições nesta tese;

À minha família, às minhas irmãs Lê e Sil pelo companheirismo, ao meu irmão Flávio e à Cristiane pela acolhida na minha chegada em Piracicaba;

À Oluanganji pela amizade e companheirismo de vida e a todos os meus irmãos espirituais por compartilharem tantas emoções;

À minha amiga Elaine pelo ombro amigo sempre;

À Márcia H. G. Tsugami por tantas boas conversas e pela torcida;

À Luciane pela ajuda com a tabulação de dados;

À minha amiga Carlinha por horas de diversão e aprendizado que começaram brilhantemente nas caronas para São Carlos;

Às minhas amigas novas Renata e Vânia, que juntamente com Zezé, Elaine e Carla fizeram muitos dias mais divertidos em nome do nosso valoroso Clube;

À Noemi, que mesmo de Buenos Aires me acalmava e à Viviane e Cláudia pelos momentos leves de troca, em Cunha ou na Praia da Fazenda;

Aos meus amigos Norma e Miura que de alguma forma me ajudam a caminhar. 


\section{SUMÁRIO}

Página

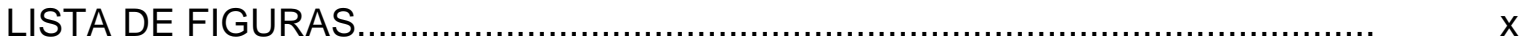

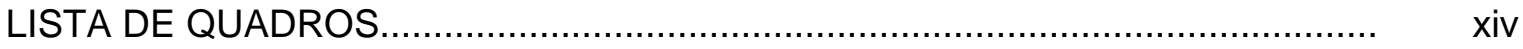

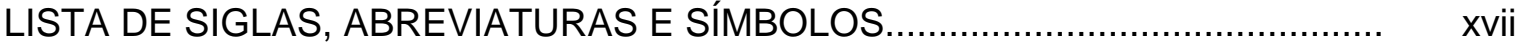

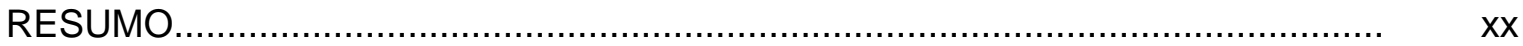

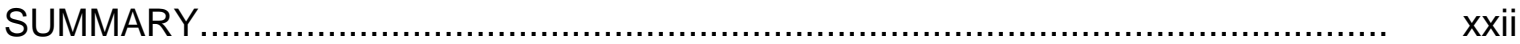

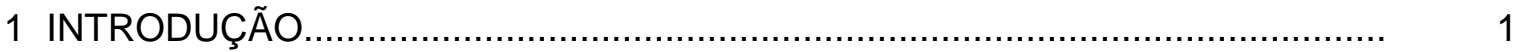

1.1 Conservação de mananciais de abastecimento público.................................. 1

1.2 Histórico da gestão de recursos hídricos no Brasil........................................ 5

1.3 A gestão dos recursos hídricos na bacia do rio Piracicaba.............................. 7

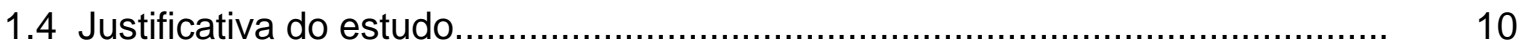

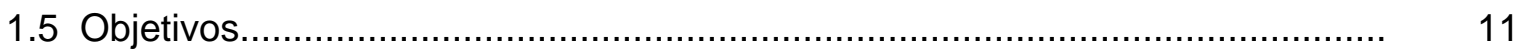

2 REVISÃO DE LITERATURA............................................................. 13

2.1 A importância da conservação de mananciais........................................... 13

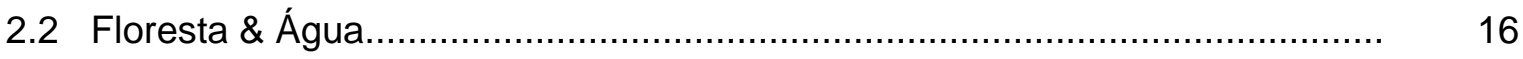

2.3 Reflexos da urbanização sobre os recursos hídricos...................................... 22

2.4 Impactos decorrentes da atividade humana e suas conseqüências para os sistemas aquáticos....................................................................... 26

2.5 Efeitos dos poluentes e reflexão sobre tratamentos mais utilizados para águas de abastecimento público....................................................... 32

2.6 Saúde da população e qualidade da água \& riscos e custos envolvidos........ 35

2.7 O monitoramento de qualidade e quantidade das águas.............................. 43 
2.8 A bacia hidrográfica como unidade de gestão, estratégias e experiências de manejo. 50

3 MATERIAL 61

3.1 Custo do tratamento de água x cobertura florestal da bacia..... 61

3.1.1 As Estações de Tratamento de Água (ETAs) e respectivas captações.

3.1.1.1 Estação de Tratamento do município de Analândia e seu manancial de captação

3.1.1.2 Estação de Tratamento do município de Rio Claro e seu manancial de captação

3.1.1.3 Estação de Tratamento de Água Capim Fino do município de Piracicaba e seu manancial de captação.

3.1.1.4 Estação de Tratamento de Água Luiz de Queiroz do município de Piracicaba e seu manancial de captação.

3.1.1.5 Estações de tratamento de água da SANASA do município de Campinas e seu manancial.

3.1.1.6 Estações de tratamento de água da SABESP/Sistema Produtor Alto Cotia da Região Metropolitana de São Paulo e seu manancial.

3.1.1.7 Estação de tratamento de água da SABESP/Sistema Cantareira, da Região Metropolitana de São Paulo e seu manancial......

3.2 Rio Corumbataí x Rio Piracicaba: perspectivas de manutenção da qualidade de um manancial de abastecimento público.

3.2.1 Caracterização geográfica e político-administrativa

3.2.1.1 Bacia hidrográfica do rio Piracicaba. 80

3.2.1.2 Bacia hidrográfica do rio Corumbataí. 84

3.2.2 Caracterização Física 87

3.2.2.1 Bacia hidrográfica do rio Piracicaba. 87

3.2.2.2 Bacia hidrográfica do rio Corumbataí. 91

3.2.3 Uso e ocupação do Solo. 97

3.2.3.1 Bacia hidrográfica do rio Piracicaba. 97

3.2.3.2 Bacia hidrográfica do rio Corumbataí. 102

3.2.4 Disponibilidade hídrica das bacias. 104

3.2.4.1 Bacia hidrográfica do rio Piracicaba. 104 
3.2.4.2 Bacia hidrográfica do rio Corumbataí.................................................... 107

3.2.5 Demografia : bacias dos rios Piracicaba e Corumbataí........................... 108

3.2.6 Caracterização Econômica: bacias dos rios Piracicaba e Corumbataí......... 113

3.2.7 Instrumentos de Planejamento Municipal: bacias dos rios Piracicaba e

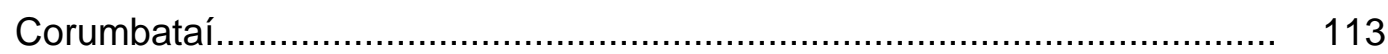

3.2.8 Qualidade de Vida: bacias dos rios Piracicaba e Corumbataí.................... 114

3.2.8.1 Índice de Desenvolvimento Humano Municipal - IDH-M....................... 114

3.2.8.2 Índice Paulista de Responsabilidade Social IPRS.................................. 115

3.2.9 Qualidade das águas das bacias dos rios Piracicaba e Corumbataí.......... 117

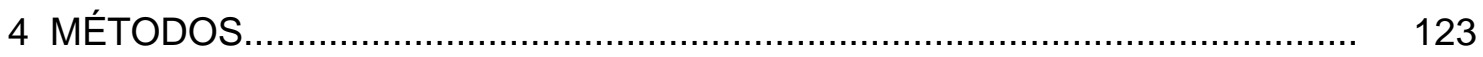

4.1 Custo do tratamento de água x cobertura florestal da bacia......................... 124

4.1.1 Determinação de custos operacionais das 7 Estações de Tratamento de

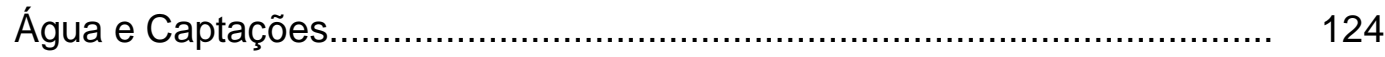

4.1.2 Qualidade dos mananciais dos 7 sistemas de abastecimento público de

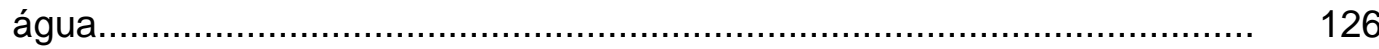

4.2 Geração de lodo nas 7 Estações de Tratamento de Água............................ 127

4.3 Rio Corumbataí x Rio Piracicaba: perspectivas de manutenção da qualidade de um manancial de abastecimento público................................. 129

4.3.1 Meio Físico, Uso e Ocupação do solo e Disponibilidade Hídrica............... 134

4.3.2 Demografia ........................................................................... 134

4.3.3 Caracterização Econômica................................................................ 135

4.3.4 Instrumentos de Planejamento Municipal.............................................. 136

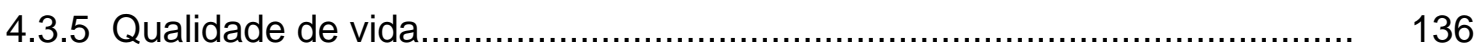

4.3.6 Qualidade das águas...................................................................... 137

5 RESULTADOS E DISCUSSÃO................................................................. 140

5.1 Custo do tratamento de água $x$ cobertura florestal da bacia......................... 140

5.1.1 Custos operacional das 7 ETAs/captações, qualidade dos mananciais e geração de lodo nas ETAs............................................................... 140

5.2 Bacia do rio Piracicaba x Bacia do rio Corumbataí.................................... 151

5.2.1 Meio Físico, Uso e Ocupação do Solo e Disponibilidade Hídrica................ 151

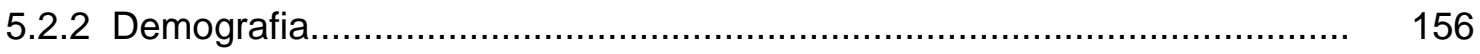

5.2.3 Caracterização Econômica................................................................ 164 
5.2.4 Instrumentos de Planejamento Municipal............................................. 166

5.2 .5 Qualidade de vida................................................................. 170

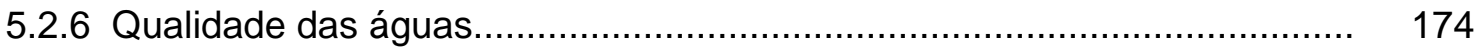

5.2.7 Reflexão sobre arranjo das instituições e legislação vigentes na bacia do rio Corumbataí e do rio Piracicaba...................................................... 188

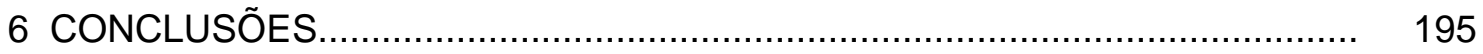

6.1 Recomendações................................................................... 199

REFERÊNCIAS BIBLIOGRÁFICAS .................................................. 201

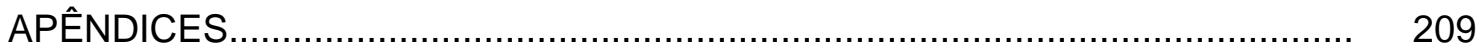




\section{LISTA DE FIGURAS}

Página

1 Ocupação da Represa Guarapiranga na Região Metropolitana de São

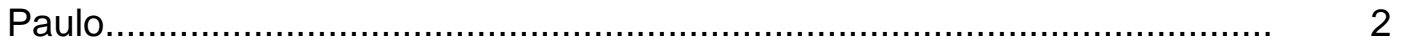

2 Constatação da precariedade do abastecimento de cidades ao redor do

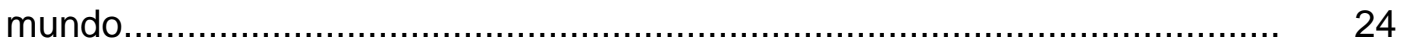

3 Localização das captações e ETAs na bacia do rio Piracicaba....................... 62

4 Captação de Analândia no córrego do Retiro, nas cabeceiras do rio Corumbataí...................................................................................... 64

5 Vista aérea do rio Corumbataí em fevereiro de 1999, na altura de porto de areia com extração no leito do rio........................................................... 66

$6 \quad$ Rio Piracicaba na altura do Engenho Central na estiagem........................... 69

$7 \quad$ Vista aérea do rio Piracicaba na altura do salto em época de chuva............. 69

8 Foto de satélite com localização da captação e ETA do Alto Cotia................ 72

9 Fluxograma de etapas de tratamento e distribuição de água da

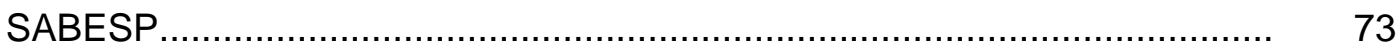

10 Chegada da água bruta à ETA Guaraú..................................................... 75

11 Imagem da cobertura florestal da bacia de drenagem do Sistema Cantareira fornecida pela SABESP.............................................................. 76

12 Vista aérea de ocupação do solo das margens de represa do Sistema

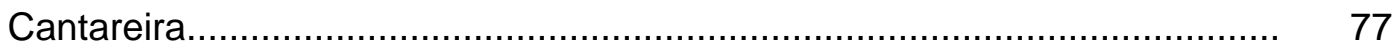

13 Localização da bacia hidrográfica do rio Piracicaba no Estado de São

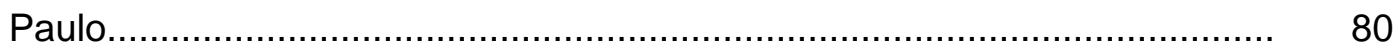

14 Bacia do rio Piracicaba e suas sub-bacias................................................ 81 
15 A bacia hidrográfica do rio Piracicaba inserida na UGRHI 05 , as principais bacias da UGRHI 05, Áreas de Proteção Ambiental .(APAs) e rede viária.

16 Localização da bacia hidrográfica do rio Corumbataí e sedes dos municípios

17 Divisão de sub-bacias da bacia hidrográfica do rio Corumbataí............ 86

18 Formações Geológicas da bacia hidrográfica do Rio Piracicaba......

19 Isoietas anuais em ( $\mathrm{mm}$ ) para a bacia hidrográfica do rio Piracicaba. 1961 a 1992.

20 Rede de drenagem da bacia do rio Piracicaba. 91

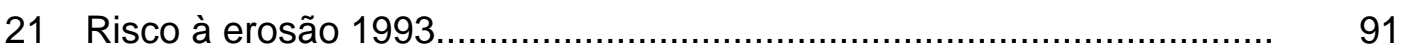

22 Mapa Geológico do rio Corumbataí.............................................. 93

23 Rede de drenagem da bacia hidrográfica do rio Corumbataí................ 95

24 Mapa de risco à erosão da bacia do rio Corumbataí.......................... 96

25 Uso e Ocupação do solo na bacia do rio Piracicaba de 1997.............. 101

26 Uso e cobertura do solo atual na bacia do rio Corumbataí................... 104

27 IAP no ano de 2002 para a bacia hidrográfica do rio Piracicaba.......... 120

28 IAP no ano de 2003 para a bacia hidrográfica do rio Piracicaba.......... 120

29 IQA para a bacia hidrográfica do rio Piracicaba............................. 121

30 IQA no ano de 2003 para a bacia hidrográfica do rio Piracicaba......... 121

31 Localização dos pontos de amostragem nos rios Piracicaba e .Corumbataí a serem estudados e outros das redes de monitoramento da CETESB

32 Fluxograma Geral Tratamento de Lodo......

33 Relação entre \% de cobertura florestal e custo com consumo de produtos químicos para cada $1000 \mathrm{~m}^{3}$ de água tratada..................... 144

34 Turbidez nos períodos de estiagem e chuvas nos 7 mananciais estudados para o ano 2002

35 Oxigênio Dissolvido nos períodos de estiagem e chuvas nos 7 mananciais estudados para o ano 2002 ......

36 Limites do perímetro da APA Corumbataí-Botucatu-Tejupá na Bacia do Rio Corumbataí. 
37 Taxas geométricas médias de crescimento anual da população total para os três períodos estudados, por classes de municípios, para a bacia do rio Piracicaba.

38 Taxas geométricas médias de crescimento anual da população total para os três períodos estudados, por classes de municípios, para a bacia do rio Corumbataí.

39 Comparação das taxas geométricas médias de crescimento da população total (\% a.a) entre as duas unidades de estudo.

40 Taxas geométricas de crescimento da população total por município (\% a.a) 1980-1991- bacia do rio Piracicaba.

41 Taxas geométricas de crescimento da população total por município (\% a.a) 1991-2000- bacia do rio Piracicaba

42 Taxas geométricas de crescimento da população total por município (\% a.a) 2000-2002- bacia do rio Piracicaba.....

43 Taxas geométricas de crescimento da população total por município (\% a.a) 1980 -1991 - bacia do rio Corumbataí.

44 Taxas geométricas de crescimento da população total por município (\% a.a) 1991-2000- bacia do rio Corumbataí.

45 Taxas geométricas de crescimento da população total por município (\% a.a) 2000-2002- bacia do rio Corumbataí.

46 Valor Adicionado Fiscal Total para as bacias dos rios Piracicaba e Corumbataí.....

47 Incentivos à implantação de empreendimentos através da isenção de taxas.

48 Incentivos à implantação de empreendimentos através da doação de terrenos.......

49 Existência de Lei municipal instituindo o Plano Diretor

50 IDH-M médio dos municípios de cada bacia hidrográfica para os anos de 1980/1991/2000.

51 IPRS para cada bacia hidrográfica para os anos de 1992 e 2000...... 173

52 AP 2003 para as águas da UGRHI 05 nos pontos de monitoramento da rede de monitoramento da CETESB 
53 IQA no rio Piracicaba de 1984 a 2000 no PCAB02192 ....................... 177

54 IQA no rio Corumbataí de 1984 a 2000 no CRUM02500.................... 178

55 Oxigênio Dissolvido no rio Piracicaba de 1978 a 2003 no

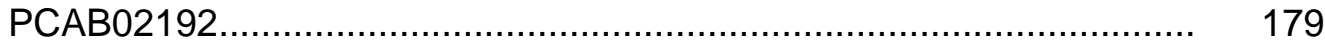

56 Oxigênio Dissolvido no rio Corumbataí de 1978 a 2003 no . CRUM2500............................................................................ 179

57 Demanda Bioquímica de Oxigênio no rio Piracicaba de 1978 a 2003

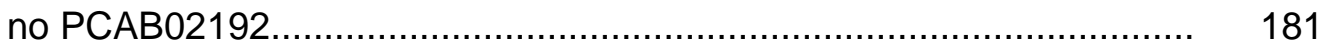

58 Demanda Bioquímica de Oxigênio no rio Corumbataí de 1978 a 2003 no CRUM2500 .......................................................................

59 Potencial de formação de THM no rio Piracicaba de 1999 a 2003 no PCAB2220 (captação) ................................................................... 184

60 Potencial de formação de THM no rio Corumbataí de 2001 a 2003 no CRUM02500 (captação)............................................................. 184

61 Giardia e Cryptosporidium no rio Piracicaba de 2001 a 2003 no PCAB02220 (Captação)........................................................... 186

62 Giardia e Cryptosporidium no rio Corumbataí de 2001 a 2002 no CRUM02500. 


\section{LISTA DE QUADROS}

Página

1 Índices de qualidade das águas nas sub-bacias da bacia do rio Piracicaba.

2 Critérios e pesos para a definição das áreas prioritárias para a conservação e recuperação florestal na Bacia do Rio Corumbataí...

3 Estação de Tratamento de Água de Analândia e seu manancial de captação.

4 Estação de Tratamento de Água ETA II de Rio Claro e seu manancial de captação.

5 Estação de Tratamento de Água Capim Fino - ETA 3 e seu manancial de captação.

6 Estação de Tratamento de Água Luis de Queiroz - ETA 1 e seu manancial de captação.

7 Conjunto de ETAs 1 e 2 (na Swift); Conjunto de ETAs 3 e 41 e seu manancial de captação.

8 ETA Alto Cotia e seu manancial.

ETA Guaraú e seu manancial..

10 Áreas das sub-bacias da bacia hidrográfica do rio Corumbataí.

11 Uso e ocupação do solo na bacia hidrográfica do rio Piracicaba......

12 Uso e cobertura do solo atual na bacia hidrográfica do rio Corumbataí.

13 Demanda e disponibilidade de água na sub-bacia do rio Piracicaba distribuída entre os diferentes usos para o ano 2000 
14 Vazões médias, máximas e mínimas mensais das sub-bacias da bacia do rio Piracicaba......

15 Relações entre demanda e disponibilidade dos recursos hídricos nas sub-bacias da bacia hidrográfica do rio Pitacicaba.

16 Demanda de água na bacia do rio Corumbataí distribuída entre os diferentes usos.

17 Populações das bacias dos rios Piracicaba, Atibaia, Corumbataí, Camanducaia, Jaguari, de 1996 a 2020.

18 Taxas de crescimento da população total dos municípios da bacia do rio Piracicaba da UGRHI - PCJ - 05

19 Taxas de crescimento da população total dos municípios da bacia do rio Corumbataí da UGRHI - PCJ - 05 e taxas de referência regionais...

20 Cargas orgânicas poluidoras provenientes de esgotos domésticos geradas nas bacias indicadas.

21 Cargas poluidoras provenientes de esgotos industriais geradas nas bacias indicadas.

22 Pontos de monitoramento da CETESB nos rios Piracicaba e Corumbataí utilizados na análise da evolução da qualidade da água......

23 Estrutura do cálculo dos Custos específicos de produtos químicos e energia elétrica das ETAs e suas captações.

24 Classificação dos municípios por faixa de população em 2000 (IBGE) bacia do rio Piracicaba.

25 Classificação dos municípios por faixa de população em 2000 (IBGE) bacia do rio Corumbataí.

26 Classes de municípios por faixa, população e percentual correspondente por unidade de estudo, para o ano 2000 (IBGE).......

27 Pontos de monitoramento da CETESB nos rios Piracicaba e Corumbataí utilizados na análise da evolução da qualidade da água...... Hierarquização do percentual de cobertura florestal e do custo específico de produtos químicos. 
31 Geração de lodo em ETAs associado ao grau de cobertura florestal da

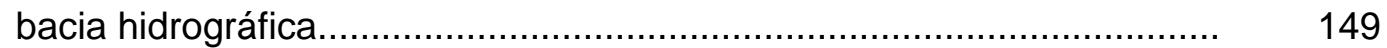

32 Uso e Ocupação do solo nas bacias do rio Piracicaba e Corumbataí..... 154

33 Relações entre Demanda e Disponibilidade dos recursos hídricos nas bacias dos rios Piracicaba e Corumbataí............................................ 155

34 Taxas geométricas de crescimento da população total ao ano para

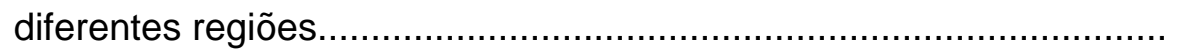




\section{LISTA DE SIGLAS, ABREVIATURAS E SÍMBOLOS}

\begin{tabular}{|c|c|}
\hline ANA & Agência Nacional de Águas \\
\hline APRM & Área de proteção e recuperação dos mananciais \\
\hline $\mathrm{BC}$ & Banco Central \\
\hline $\mathrm{CBH}-\mathrm{PCJ}$ & Comitê de Bacias Hidrográficas dos rios Piracicaba/Capivari/Jundiaí \\
\hline CEEIAPI & $\begin{array}{l}\text { Comitê Executivo de Estudos Integrados das bacias dos rios Jaguari e } \\
\text { Piracicaba }\end{array}$ \\
\hline CEEIBH & Comitê Especial de Estudos Integrados de Bacias Hidrográficas \\
\hline CELADE & Centro Latino-americano de Demografia \\
\hline CETESB & Companhia de Tecnologia de Saneamento Ambiental \\
\hline COD & Carbono orgânico dissolvido \\
\hline CONAMA & Conselho Nacional do Meio Ambiente \\
\hline $\mathrm{CRH}$ & Conselho Estadual de Recursos Hídricos \\
\hline СТMH & Câmara técnica de monitoramento hidrológico \\
\hline DAEE & Departamento de águas e Energia Elétrica \\
\hline DBO & Demanda bioquímica de oxigênio (mg/L) \\
\hline DBP & Subprodutos do processo de desinfecção (Desinfection by products) \\
\hline DE-IB & Departamento de ecologia geral, Instituto de Biociências \\
\hline EPA & Agência de Proteção Ambiental dos EUA \\
\hline ETA & Estação de Tratamento de Água \\
\hline ETE & Estação de Tratamento de Esgotos \\
\hline FERROBAN & Ferrovias Bandeirantes S/A \\
\hline FGV & Fundação Getúlio Vargas \\
\hline
\end{tabular}




\begin{tabular}{|c|c|}
\hline FUNASA & Fundação Nacional de Saúde \\
\hline IAP & Índice de Qualidade das águas para abastecimento público \\
\hline IBGE & Instituto Brasileiro de Geografia e Estatística \\
\hline ICMS & Imposto de circulação sobre mercadorias e serviços \\
\hline IDH & Índice de desenvolvimento humano \\
\hline IDH-M & Índice de desenvolvimento humano municipal \\
\hline IGP - DI & Índice geral de preços - Disponibilidade Interna \\
\hline IPEF & Instituto de Pesquisas e Estudos Florestais \\
\hline IPT & Instituto de Pesquisas Tecnológicas do Estado de São Paulo S.A. \\
\hline IPRS & Índice paulista de responsabilidade social \\
\hline IQA & Índice de qualidade das águas \\
\hline ISTO & Índice de Substâncias Tóxicas e Organolépticas \\
\hline IVA & Índice de Qualidade de água para proteção da vida aquática \\
\hline MDC & Comissão Distrital Metropolitana \\
\hline NMP & Número mais provável \\
\hline OD & Oxigênio Dissolvido (mg/L) \\
\hline ONU & Organização das Nações Unidas \\
\hline PIB & Produto Interno Bruto \\
\hline PROÁLCOOL & Programa Nacional do Álcool \\
\hline RMSP & Região Metropolitana de São Paulo \\
\hline SABESP & Companhia de Saneamento Básico do Estado de São Paulo \\
\hline SANASA & Sociedade de Abastecimento de Água e Saneamento S/A \\
\hline SEADE & Fundação Sistema estadual de análise de dados \\
\hline SEMA & Secretaria de Meio Ambiente \\
\hline SEMAE & Serviço municipal de água e esgoto de Piracicaba \\
\hline SIG & Sistema de informações geográficas \\
\hline SMA & Secretaria de Estado do Meio Ambiente de São Paulo \\
\hline ST & Sólidos totais \\
\hline THM & Trihalometanos \\
\hline THMPF & Potencial de formação de trihalometanos \\
\hline TTHM & Trihalometanos totais \\
\hline UFESP & Unidade Fiscal do Estado de São Paulo \\
\hline
\end{tabular}


UGRHI Unidade de gerenciamento de recursos hídricos

USA

Estados Unidos da América

USEPA

Agência de Proteção Ambiental dos EUA

WMO

Organização Meteorológica Mundial

WWF

World Wild Life Fund 


\title{
COBERTURA FLORESTAL E CUSTO DO TRATAMENTO DE ÁGUAS EM BACIAS HIDROGRÁFICAS DE ABASTECIMENTO PÚBLICO: CASO DO MANANCIAL DO MUNICÍPIO DE PIRACICABA
}

\author{
Autora: LUCIA VIDOR DE SOUSA REIS \\ Orientador: Prof. Dr. WALTER DE PAULA LIMA
}

\section{RESUMO}

A sociedade necessita de indicadores capazes de medir a susceptibilidade ao risco de degradação de um manancial de abastecimento público. $\mathrm{O}$ percentual de cobertura florestal de uma bacia hidrográfica pode ser utilizado como um dos indicativos na avaliação da qualidade de um manancial de abastecimento público. O custo do tratamento de águas provenientes de bacias hidrográficas com diferentes percentuais de cobertura florestal é um componente que pode subsidiar discussões sobre a importância da cobertura florestal em mananciais de abastecimento público, como recurso ambiental a ser priorizado pelo poder público e exigido pela sociedade, tendo em vista os benefícios econômicos e de minimização de riscos à saúde humana. O trabalho determinou os custos do tratamento da água proveniente de bacias hidrográficas com diversos percentuais de cobertura florestal através da análise das características operacionais de diversas Estações de Tratamento de Água (ETAs) e suas respectivas captações. Para seis dos sete sistemas e ETAs estudadas, o custo específico com produtos químicos na ETA eleva- se com a redução do percentual de cobertura florestal da bacia de abastecimento. Não se pretendeu situar e associar a localização das áreas de cobertura florestal a outros fatores como, por exemplo, a susceptibilidade do solo à erosão ou ao percentual de área florestada 
situada em APP's. Considerando-se o enfoque do trabalho sobre a qualidade de mananciais de abastecimento público e a relevância do episódio de rejeição do rio Piracicaba no ano 2000 como principal manancial de abastecimento público do município de mesmo nome, em decorrência da perda de qualidade de suas águas, dos altos custos do tratamento e da impossibilidade de garantir água de consumo humano de qualidade, o trabalho teve por objetivo também analisar as perspectivas para a qualidade das águas do rio Corumbataí, novo manancial eleito para Piracicaba. Utilizou-se como recurso a análise de dados de caracterização física das bacias e sócio-econômica dos municípios das bacias dos rios Piracicaba e Corumbataí, e da qualidade das águas dos rios Piracicaba e Corumbataí. O estudo faz uma reflexão sobre o atual arranjo de instituições públicas, suas atribuições legais e ferramentas para a aplicação de leis e implementação de ações de planejamento regional nas bacias dos rios Corumbataí e Piracicaba. 


\title{
FOREST COVER AND THE COST OF WATER TREATMENT IN MUNICIPAL WATERSHADES: THE CASE OF THE PIRACICABA MUNICIPAL WATERSHED
}

\author{
Author: LUCIA VIDOR DE SOUSA REIS \\ Adviser: Prof. Dr. WALTER DE PAULA LIMA
}

\section{SUMMARY}

The Society needs to be able to check when a water source for public supply is about to reach a degradation level. The percentage off forest covered in the watershed can be used as one of the indicators to measure the quality of a public water source. The cost of water treatment from different water supply areas containing different percentage of soil forest cover, is a component that can be brought into discussions about the importance of the forest cover in drinking water public supply areas, as an environmental natural resource, to be prioritized by the Authorities, and mandatory by the Society, heading to both economical benefits and the human health risks minimization. This work has determined the costs of water treatment from water supply areas with different percentages of natural forest cover, analysis of all operating data of all Treatment Water Stations (ETAs), as well as their water sources. For six out of seven studied systems and ETAs, the specific cost with chemical products in one ETA increases with the reduction of the known portion of rain forest for the watershed. Certainly this study was not intended to try to associate the forest location areas to other factors, as for example, the erosion soil characteristic or to the portion of forest cover, located in riparian areas. Considering the focus of this work about the public supply of drinking water and the recent episode of the Piracicaba river rejection as the main water supply for the Region in year 2000, because of the low level quality of its water, the high treatment costs, and the impossibility to make feasible to count on 
it to distribute good quality water, this work had also the purpose of analyzing the perspectives for the Corumbataí river, to be elected as the main source of water supply for Piracicaba. Socio-economic of all cities along the river basins of Piracicaba and Corumbataí has been studied. Besides the organization of all administrative offices in charge with the problem, their legal functions and possible available tools to plan and to work properly, has also been analyzed. 


\section{INTRODUÇÃO}

\subsection{Conservação de mananciais de abastecimento público}

A conservação de mananciais é desejável e fundamental para a produção de água para consumo humano de melhor qualidade e sujeita a menores riscos potenciais à saúde. No Estado de São Paulo, as instituições públicas têm algumas tentativas registradas visando efetivar a proteção de mananciais, podendo-se ressaltar a Lei estadual $n^{\circ} 898$ de 1975, que disciplina o uso do solo para a proteção dos mananciais, cursos e reservatórios de água e demais recursos hídricos de interesse da Região Metropolitana da Grande São Paulo e a Lei estadual no 9866 de 1997, que estabelece diretrizes e normas para a proteção e a recuperação da qualidade ambiental das bacias hidrográficas dos mananciais de interesse regional para abastecimento das populações atuais e futuras do Estado de São Paulo, assegurados, desde que compatíveis, os demais usos múltiplos. No entanto, não se pode dizer que até agora houve sucesso no cumprimento integral dessa legislação. A Lei $n^{\circ} 898$ de 1975 teve várias de suas limitações de ocupação desrespeitadas. A ocupação desordenada da área de proteção delimitada da represa de Guarapiranga é um exemplo dessa afirmativa (Figura 1).

Na Lei no 9866 de 1997 define-se Área de Proteção e Recuperação dos Mananciais (APRM) como uma ou mais sub-bacias hidrográficas dos mananciais de interesse regional para abastecimento público. A APRM deverá estar inserida em uma das Unidades de Gerenciamento de Recursos Hídricos (UGRHI), previstas no Sistema Integrado de Gerenciamento de Recursos Hídricos (SIGRH), instituído pela Lei no 7663 , de 30 de dezembro de 1991. Conforme previsto no texto da Lei, as APRMs serão definidas e delimitadas mediante proposta do Comitê de Bacia Hidrográfica e por 
deliberação do Conselho Estadual de Recursos Hídricos $\mathrm{CRH}$, ouvidos o Conselho Estadual de Meio Ambiente (CONSEMA) e o Conselho de Desenvolvimento Regional (CDR). Entretanto a discussão da proposição de APRMs ainda não ganhou a importância necessária dentro da quase totalidade dos Comitês de bacias organizados no Estado de São Paulo. A UGRHI 05 composta pelas bacias dos rios Piracicaba, Capivari e Jundiaí, não possuem nenhuma APRM.

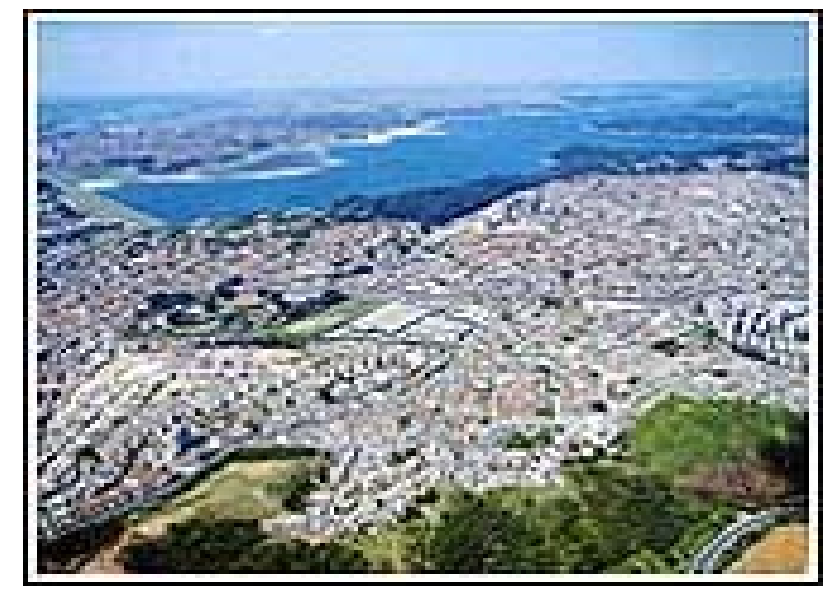

Figura 1 -Ocupação da Represa Guarapiranga na Região Metropolitana de São Paulo

A manutenção da cobertura florestal é primordial dentre tantos outros fatores necessários à preservação da qualidade das águas de um manancial. A localização desta cobertura florestal numa bacia hidrográfica é relevante para que o meio se beneficie de suas funções, visando garantir a manutenção da qualidade das águas. As áreas de preservação permanente (APP's) definidas pelo Código Florestal , Lei $n^{0} 4.771$ de 15 de setembro de 1965, que se encontram em regiões da paisagem, como por exemplo ao redor das nascentes a ao longo dos cursos d'água, têm importância na produção de água, em qualidade e quantidade. O Código Florestal estabelece a proteção de áreas de preservação permanente ao longo de corpos d'água, nascentes e reservatórios e legisla sobre áreas de Reserva Legal obrigatórias em propriedades, que podem ser compensadas em outras propriedades, desde que na mesma Unidade de Gerenciamento de Recursos Hídricos (UGRHI).

O Decreto Estadual 8468/76, que regulamentou a Lei 997/76 e dispõe 
sobre a prevenção e o controle da poluição do meio ambiente é o principal instrumento de controle da Companhia Estadual de Tecnologia Ambiental (CETESB) sobre fontes de poluição, que, dentre outros objetivos, visa garantir a qualidade de mananciais de abastecimento público. A CETESB foi criada em 1973, através de Lei estadual $n^{\circ} 118$, com diversas atribuições, dentre as quais, "efetuar o controle de qualidade das águas destinadas ao abastecimento público e a outros usos, assim como das águas residuárias".

Considerando-se a influência que o manejo e o uso do solo exercem sobre os mananciais de abastecimento público, cabe destacar a existência da Lei estadual paulista no 6171 de 04 de julho de 1988, alterada pela Lei no 8421 de 23 de novembro de 1993, que dispõe sobre o uso, conservação e preservação do solo agrícola no Estado de São Paulo. A Lei aborda questões importantes que têm reflexo direto sobre mananciais de abastecimento público, tais como:, controlar a erosão do solo em todas as suas formas, zelar pelo aproveitamento adequado e pela conservação das águas em todas as suas formas, evitar assoreamento de cursos de água e bacias de acumulação. A atribuição de aplicação desta Lei é da Secretaria de Agricultura e Abastecimento, que deve, dentre outras competências, atuar em harmonia com o Governo Federal e os Municipais nas ações pertinentes à permanente conservação do solo e da água e fiscalizar e fazer cumprir as disposições da lei.

Apesar de legislação tão vasta que permitiria uma maior proteção dos mananciais de abastecimento público, a cultura das instituições e da sociedade no Brasil normalmente caminha para obter a solução para a geração de água potável, através da execução de grandes obras de engenharia e aplicação adequada de produtos químicos. A importância da existência de florestas preservando mananciais de abastecimento público, ou a necessidade de manejar o solo no meio rural adequadamente, são temas que não ocupam espaço na maioria dos fóruns onde atualmente debate-se a gestão da água. Parte deste trabalho propõe-se a relacionar a presença das florestas nas bacias de abastecimento público com a qualidade das águas dos mananciais, não estabelecendo a discussão sobre o manejo do solo rural e urbano, porém reconhecendo a interferência que a gestão destes meios exerce sobre a qualidade das águas.

Na Câmara Técnica de Monitoramento Hidrológico (CTMH), do Comitê de Bacias Hidrográficas dos rios Piracicaba, Capivari e Jundiaí (CBH/PCJ), reúnem-se 
mensalmente os responsáveis pelos serviços de água de todos os municípios da bacia do rio Piracicaba, juntamente com o Departamento de Águas e Energia Elétrica do Estado de São Paulo (DAEE), Companhia Estadual de Tecnologia de Saneamento Ambiental (CETESB) e mais outros órgãos estaduais. A discussão neste fórum recai regularmente sobre a quantidade de produto a ser adicionada para que seja superada determinada situação desfavorável de tratabilidade da água de abastecimento. Com raras exceções, o município não possui visão de sua responsabilidade sobre o manancial que ele elegeu e sobre as ações que ele deva tomar para evitar sua degradação.

A vigência da Portaria Federal do Ministério da Saúde 1469 de 2001, recentemente substituída pela Portaria no 518 de 25 de março de 2004, que estabelece procedimentos e responsabilidades relativas ao controle e vigilância da qualidade da água para consumo humano e seu padrão de potabilidade, deu contribuição importante à visão sobre o controle da qualidade das águas de abastecimento público, considerando, pela primeira vez, a responsabilidade do município sobre o manancial de onde emana sua água. No Estado de São Paulo, até então, apenas a CETESB era responsabilizada pela qualidade das águas, ficando o município com papel passivo neste processo.

O percentual de cobertura florestal da bacia de drenagem de um manancial para abastecimento público tem reflexos sobre o custo de tratamento das águas. Tratar águas de mananciais com diferentes tipos de ocupação e baixo nível de cobertura florestal é mais caro e menos seguro do que tratar águas de mananciais mais protegidos por cobertura florestal e portanto com menor interferência antrópica.

Como exemplo inédito no Estado de São Paulo de tentativa de gestão pública sobre um manancial de abastecimento público através da recuperação florestal, o Serviço Municipal de Água e Esgoto de Piracicaba (SEMAE), em 1999, contratou o Instituto de Pesquisas e Estudos e Pesquisas Florestais (IPEF) para a elaboração do Plano Diretor da bacia do rio Corumbataí para conservação dos recursos hídricos por meio da recuperação e da conservação da cobertura florestal. A iniciativa deve ser prestigiada pois a abordagem do enfoque sobre a gestão de um manancial de abastecimento público assemelha-se ao que de mais atual vem se fazendo em países como o Canadá e regiões dos Estados Unidos.

$\mathrm{Na}$ busca de ilustrar o crescente problema da perda da qualidade dos 
mananciais de abastecimento público, a bacia hidrográfica do rio Piracicaba, situada no Estado de São Paulo, oferece muitos exemplos. O caso que merece destaque refere-se ao município de Piracicaba, que rejeitou o rio Piracicaba como principal manancial do município desde o ano 2000, para substituí-lo pelo rio Corumbataí, um dos principais afluentes do rio Piracicaba. Desde que o rio Piracicaba foi considerado um manancial inadequado para o município de Piracicaba registraram-se evoluções na gestão de recursos hídricos, particularmente na legislação federal e na ação dos comitês de bacias hidrográficas estadual e federal. Entretanto estes marcos são insuficientes para que se vislumbre uma mudança acelerada no planejamento ambiental e econômico dos municípios da bacia.

Este trabalho tem assim o objetivo de contribuir com a discussão sobre o conceito de adequação de um manancial de abastecimento público, sobre a importância da relação floresta \& água em mananciais de abastecimento público e sobre as perspectivas para a manutenção do rio Corumbataí como principal manancial do município de Piracicaba, observada a rejeição do rio Piracicaba desde o ano 2000. O princípio de que as soluções tradicionais de engenharia civil são insuficientes para garantir a oferta de água potável de qualidade à população também é parte da reflexão deste trabalho.

\subsection{Histórico da gestão de recursos hídricos no Brasil}

No Brasil, ao se analisar historicamente a utilização dos recursos hídricos, observa-se que estes aparecem prioritariamente como insumo básico para o desenvolvimento econômico, pois a exploração do potencial energético sempre foi privilegiada, em detrimento dos demais usos. (SÃO PAULO, 1995). Este enfoque sobre os recursos hídricos é formador de cultura que está até hoje enraizada nas instituições nacionais, nas diversas esferas de poder, que têm dificuldade de atentar para o fato de que mananciais de abastecimento público devem possuir atenção especial das autoridades e da sociedade civil, ou não sobreviverão às pressões desenvolvimentistas.

A partir dos anos 70 sente-se o acirramento dos problemas advindos do processo de desenvolvimento econômico e da industrialização, como o aumento da poluição industrial, a falta de saneamento e abastecimento. A questão ambiental passa 
a ser discutida em vários países, levando à realização, em 1972, da $1^{\text {a }}$ Conferência das Nações Unidas sobre Meio Ambiente, em Estocolmo. O Brasil nesta Conferência enfatizou o crescimento econômico em detrimento da preservação ambiental. Respondendo a uma questão diplomática frente à posição do país em Estocolmo, o governo federal criou a Secretaria Especial do Meio Ambiente - SEMA, em outubro de 1973(SÃO PAULO, 1995).

Em 1978, o governo federal brasileiro, na tentativa de fazer uma reformulação institucional na área de recursos hídricos, criou o Comitê Especial de Estudos Integrados de Bacias Hidrográficas (CEEIBH). Em 1983, foi realizado um seminário internacional de gestão de recursos hídricos, que possibilitou um intercâmbio de informações com representantes da França, Inglaterra e Alemanha. Essas iniciativas resultaram na formação de uma consciência nacional, o que teria facilitado o encaminhamento de propostas como a inclusão do artigo 21, na Constituição Federal de 1988, que atribui à União, a competência sobre o Sistema Nacional de Gerenciamento dos Recursos Hídricos (Lanna, 1995).

$\mathrm{Na}$ Constituição Federal de 1988 foi previsto um Sistema Nacional de Recursos Hídricos. A legislação regulamentadora desse sistema só foi aprovada em 1997, com a aprovação da Lei Federal n. ${ }^{\circ}$ 9433. Esta Lei instituiu a Política Nacional de Recursos Hídricos, criando o Sistema Nacional de Gerenciamento dos Recursos Hídricos e comitês de bacias federais. Posteriormente, em 2002, instalou-se a Agência Nacional de Águas, a ANA, que implementou a cobrança pelo uso da água em algumas bacias de domínio federal. 


\subsection{A gestão dos recursos hídricos na bacia do rio Piracicaba}

No Estado de São Paulo, a Constituição Estadual de 1989 contemplou a gestão de recursos hídricos através de seção específica relativa à implementação de um sistema para gestão desse recurso, que culminou com a Lei $n^{\circ} 7663$ de 1991 . O artigo 205 da Constituição Estadual afirma que o Estado instituirá o sistema integrado de gerenciamento de recursos hídricos, congregando órgãos estaduais, municipais e a sociedade civil (SÃO PAULO, 1995).

$\mathrm{Na}$ bacia hidrográfica do rio Piracicaba, entre as décadas de 60 e 70

instalou-se o Sistema Cantareira, complexo situado nas cabeceiras da bacia, que transporia $31 \mathrm{~m} 3 / \mathrm{s}$ de água para abastecimento público da região da Grande São Paulo. Nessa época, o Pró-álcool estava ativo e houve explosão populacional na região, com reflexo sobre os recursos hídricos. A instalação do Sistema Cantareira acompanhada da explosão demográfica e industrial implicaram na aceleração da degradação dos recursos hídricos, pela diminuição da vazão afluente da bacia e pelo aumento da carga poluidora sem tratamento. Estes fatos mobilizaram a população que reagiu com manifestações em defesa do Rio Piracicaba. A sociedade civil organizada, a comunidade científica, as forças políticas buscaram trazer para a região escritórios da CETESB, DAEE e DEPRN, o que acabou acontecendo por volta de 1984 (CBH-PCJ, 1996).

Em 1982, baseada numa portaria interministerial do governo federal, que possibilitava a criação de comitês de bacias hidrográficas de rios federais, foi criado em 1982, sob a presidência do DAEE, o Comitê Executivo de Estudos Integrados das bacias dos rios Jaguari e Piracicaba (CEEIAPI), composto por órgãos federais e estaduais. Este Comitê não tinha mecanismos de suporte financeiros e foi extinto em 1988 (CBH-PCJ, 1996).

Em 1985 houve o lançamento da "Campanha Ano 2000 - Redenção Ecológica da Bacia do Rio Piracicaba", resultando na declaração oficial da criticidade da bacia do rio Piracicaba, pelo governo estadual. Em 1987, o governo estadual criou o Conselho Estadual de Recursos Hídricos ( $\mathrm{CRH})$, para propor uma política, estruturar um sistema de gestão de águas e elaborar o Plano Estadual de Recursos Hídricos; paralelamente foi também estabelecido o Comitê Coordenador do Plano Estadual de 
Recursos Hídricos (CORHI) e o Grupo Técnico da Bacia do Piracicaba - GTPI, que tinha por objetivo administrar os interesses de municípios e do estado sobre os recursos hídricos. Em 1989, foi fundado o Consórcio das Bacias dos Rios Piracicaba e Capivari, que agregava municípios e empresas, visando contribuir com a gestão e despoluição dos recursos hídricos das bacias hidrográficas (CBH-PCJ, 1996).

Em 1991, com a promulgação da Lei Estadual 7663/91, o Estado de São Paulo foi dividido em unidades de gerenciamento hidrográfico (UGRHIs) e ficou definida a Política Estadual de Recursos Hídricos. Nas disposições transitórias dessa Lei foi criado o Comitê de Bacias Hidrográficas dos rios Piracicaba/Capivari/Jundiaí, CBH-PCJ (CBH-PCJ, 1996).

Em 1993 foi instalado o Comitê de Bacias Hidrográficas dos rios Piracicaba/Capivari/Jundiaí, CBH-PCJ. O comitê possui diversas câmaras técnicas que visam subsidiar as decisões do fórum principal.

Em 2003 foi instalado o Comitê Federal das bacias dos rios Piracicaba/Capivari/Jundiaí, que trabalha em câmaras técnicas conjugadas com o comitê estadual, já anteriormente instalado. Há grande expectativa diante da instalação da cobrança pelo uso da água, que deverá ter, parte ou todo, o recurso revertido para as bacias hidrográficas geradoras do mesmo.

O município de Piracicaba rejeitou o rio Piracicaba como seu principal manancial de abastecimento público a partir do ano 2000. O rio Piracicaba, desde então, complementa a captação do município apenas em situações eventuais. O rio Corumbataí, afluente do rio Piracicaba, tornou-se então o principal manancial de abastecimento público do município de Piracicaba. Este fato, que passou quase despercebido pela maioria das instituições e da sociedade civil, reflete o comprometimento da qualidade das águas do rio Piracicaba ao longo de um intervalo de tempo que pode ser considerado curto.

Desde o final do século XIX o rio Piracicaba foi utilizado para 0 abastecimento público do município, ou seja, há pelo menos 120 anos. Até 1926, a água distribuída à população era bruta e vinha diretamente do rio Piracicaba, sem nenhum tratamento e somente em 1927 foi instalada a primeira estação de tratamento de água (SEMAE, 2003). A partir da década de 60 a migração da maior parte da população para as zonas urbanas acentuou-se, juntamente com o desenvolvimento industrial crescente na década de 70 , pressionando, de forma negativa, a qualidade 
dos cursos d'água da região, observando-se os segmentos urbano, industrial e rural.

São então, pelo menos 120 anos de uso das águas do rio Piracicaba, sendo que nos últimos anos sua qualidade vem decrescendo gradualmente, culminando com a mudança da captação principal do município de Piracicaba para o rio Corumbataí. A perda parcial deste manancial de abastecimento público nos leva a refletir sobre quanto custou ou custará este abandono a esta ou a futuras gerações.

A situação de degradação dos recursos hídricos da bacia hidrográfica do rio Piracicaba está demonstrada no Quadro 1 e representa o maior desafio ao recém instalado Comitê federal das bacias hidrográficas dos rios Piracicaba/Capivari /Jundiaí. De acordo com o Relatório da Qualidade das Águas e Interiores da CETESB de 2002, a qualidade das águas dos principais rios da bacia está representada através dos índices: IQA (Índice de qualidade das águas), IVA (Índice de qualidade para proteção da vida aquática) e IAP (Índice de qualidade das águas brutas para fins de abastecimento público).

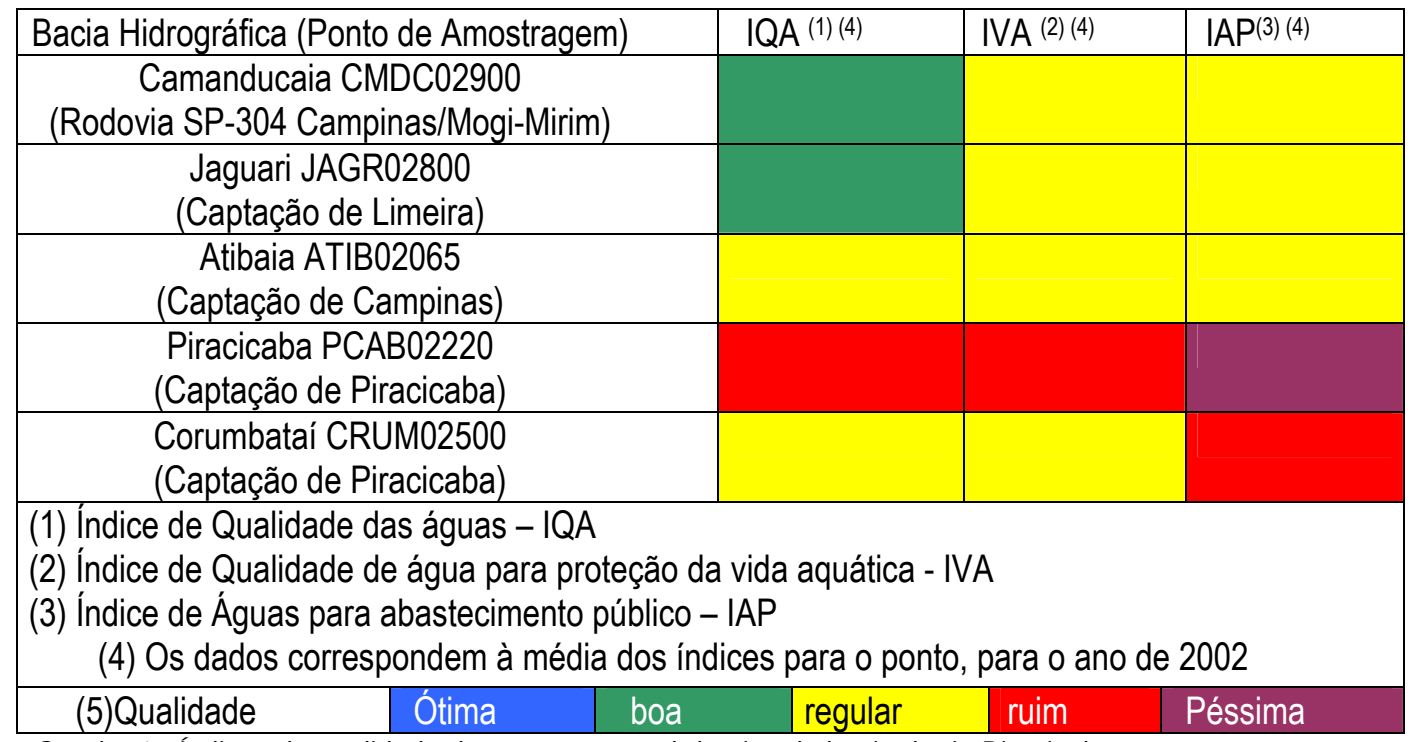

Quadro 1 - Índices de qualidade das águas nas sub-bacias da bacia do rio Piracicaba

Fonte: CETESB, 2003

O IQA, desde a década de 80 , foi tradicionalmente utilizado pela CETESB para atribuir um valor à qualidade das águas do Estado de São Paulo, transformando os dados de análises das amostras em informação para a sociedade . 
Desde 2002, a CETESB introduziu os índices IVA e IAP buscando refinar a informação sobre a qualidade das águas para usos específicos. O IQA não é o índice mais apropriado para posicionar a sociedade sobre a qualidade das águas de um rio para fins de abastecimento público. Observando-se o Quadro 1 para o rio Corumbataí, na captação de água para o município de Piracicaba, onde o IQA indicava em 2002 qualidade regular, o IAP indicava qualidade ruim. A sofisticação e a adequação da construção de índices revelam situações que anteriormente podiam ser sentidas apenas por quem as vivenciava, como por exemplo pelos técnicos de uma estação de tratamento de água, ou ainda pela população que consumia a água tratada.

\subsection{Justificativa do estudo}

O aumento de conflitos pelo uso da água e a ineficiência das instituições em construir arranjo e ferramentas que sejam capazes de reverter a situação crescente da degradação de mananciais de abastecimento público justifica a busca de indicativos que demonstrem a evolução do estado de conservação desses mananciais.

Diante da política de cobrança pelo uso da água, já vigente em pelo menos um comitê de bacias no Estado de São Paulo, a quantificação do custo de tratamento de águas provenientes de bacias hidrográficas com percentuais de cobertura florestal diferenciados pode ser importante no estabelecimento de valores cobrados da sociedade. A sociedade pode optar ao longo do tempo pela pressão e execução de medidas que visem melhorar o grau de conservação dos mananciais também por razões econômicas.

A imensa quantidade de substâncias introduzidas no meio através dos esgotos urbanos e industriais é indesejável para mananciais de abastecimento público. A reflexão sobre os riscos à saúde associados à proveniência de águas de mananciais em estado de conservação ruim e com grande interferência antrópica faz-se necessária, para que a sociedade passe a conhecer e se preocupar com a origem e com a qualidade da água consumida.

Considerando-se o enfoque do trabalho sobre a qualidade de mananciais de abastecimento público e a relevância do episódio de rejeição do rio Piracicaba no ano 2000 como principal manancial de abastecimento público do 
município de mesmo nome, tornou-se imperativo analisar as perspectivas para a qualidade das águas do rio Corumbataí.

\subsection{Objetivos}

As hipóteses que nortearam o trabalho foram:

Não há índices disponíveis capazes de medir a susceptibilidade ao risco de degradação de um manancial de abastecimento público.

O percentual de cobertura florestal de uma bacia hidrográfica pode ser utilizado como um primeiro indicativo na avaliação da qualidade de um manancial de abastecimento público.

O estado de conservação de uma bacia hidrográfica determina os custos de tratamento das águas para abastecimento público e os riscos à saúde associados a este estado.

Se nenhum gerenciamento ambiental rural for pensado e executado para a bacia do rio Corumbataí, em alguns anos ela estará comprometida como manancial de abastecimento público do município de Piracicaba.

Considerando as hipóteses que nortearam o desenvolvimento do trabalho, foram estabelecidos dois objetivos:

Objetivo 1: estabelecer o custo do tratamento de águas provenientes de bacias hidrográficas com diferentes percentuais de cobertura florestal, buscando subsidiar discussões sobre a importância da cobertura florestal em mananciais de abastecimento público, como recurso ambiental a ser priorizado pelo poder público e exigido pela sociedade, tendo em vista os benefícios econômicos e de minimização de riscos à saúde humana.

Objetivo 2: mostrar as perspectivas sobre a qualidade das águas do rio Corumbataí, manancial de abastecimento público do município de Piracicaba, considerado o percentual de 
cobertura florestal da bacia, a atual situação de degradação do rio Piracicaba e o arranjo institucional vigente. Tal análise será realizada a partir do confronto de características físicas, sócioeconômicas, ambientais e de planejamento obtidas para as bacias dos rios Corumbataí e Piracicaba. 


\section{REVISÃO DE LITERATURA}

\subsection{A importância da conservação de mananciais}

A água é um recurso natural imprescindível à vida, ao desenvolvimento econômico e ao bem estar social. No entanto, a cada dia este recurso está cada vez mais escasso, devido a políticas prejudiciais aos usos múltiplos das águas e degradado pelos altos índices de cargas poluidoras de origem urbana, industrial e agrícola $(\mathrm{CBH}-$ PCJ, 1996). A modificação da dinâmica da paisagem também é crucial na determinação da escassez da água.

Segundo Lima (1996), embora a água seja essencial à vida, todavia, devido a sua aparente inesgotabilidade, nunca o homem se preocupou devidamente com a necessidade de conservação deste importante recurso natural. Para o cidadão comum, a água deve estar disponível à torneira para seu uso.

Atualmente é cada vez maior a preocupação dos técnicos e leigos para com a conservação da água. A escassez de água potável já é um problema levado a sério em muitos países (Walton, 1970).

O conceito do desenvolvimento sustentável prevê que os recursos naturais renováveis sejam utilizados de forma tal que não limitem sua disponibilidade para as presentes e futuras gerações. Portanto, um dos maiores desafios a enfrentar para alcançar o desenvolvimento sustentável será minimizar os efeitos da escassez da água e da poluição, particularmente nos países em desenvolvimento (Salati et al., 1999).

Segundo Lima (1996), a conservação da água não pode ser alcançada sem a conservação dos outros recursos naturais. O autor complementa que essa relação existe porque o comportamento da água na terra, ou seja, o comportamento da 
fase terrestre do ciclo hidrológico reflete diretamente as condições, os usos e coberturas do terreno (solo, vegetação, etc.) de onde ela emana.

Lima (2000) afirma que, na natureza, a permanência dos recursos hídricos, em termos de regime de vazão dos córregos, ribeirões e rios e da qualidade da água que emana das microbacias hidrográficas, decorre de mecanismos naturais de controle desenvolvidos ao longo de processos evolutivos da paisagem, que constituem os chamados serviços proporcionados pelo ecossistema. Um destes mecanismos, segundo o autor, é a reconhecida relação íntima que existe entre a cobertura florestal e a água, que é acentuada principalmente nas regiões de cabeceira de drenagem, onde estão as nascentes e os nascedouros dos rios.

De acordo com Lima (1996) e Chansheng et al. (2000), em hidrologia florestal tem-se por princípio básico que a produção de água de uma microbacia hidrográfica é significativamente influenciada pela presença da cobertura florestal.

O manejo de mananciais, quando está relacionado ao abastecimento, deve ter por objetivo principal a produção de água em qualidade e em quantidade adequados. Essa condição será obtida quando, a microbacia hidrográfica apresentar condições ambientais desejáveis. Esta saúde de uma microbacia pode ser avaliada em relação à sua capacidade de sustentar, concomitantemente com o uso dos recursos naturais pelo homem (produção agrícola, produção florestal etc.), pelo menos os seguintes atributos ou indicadores: perpetuação de seu funcionamento hidrológico (regime de vazão, quantidade e qualidade da água), potencial produtivo do solo ao longo do tempo (biogeoquímica) e biodiversidade (mata ciliar, zonas ripárias, reservas de vegetação natural etc.) (Lima,1999).

Swanson (1998) mostra sua preocupação sobre a necessidade de aplicação de conhecimentos de hidrologia florestal no manejo de operações florestais, observando-se sua influência sobre os usuários da água. O autor refere-se à necessidade de qualificação das escolas de engenharia florestal envolvendo o tema, afirmando que os usuários da água estão pressionando os gerenciadores florestais a exercerem seus papéis, considerando o uso das águas para abastecimento público. Segundo o autor, os responsáveis pelo manejo florestal, em geral, estão mal equipados para corresponderem à esta expectativa da população.

A manutenção de fontes de água para abastecimento público, limpas e seguras, está se tornando uma prioridade crescente em decorrência da poluição global. 
Para se atingir o objetivo de manter limpos os mananciais de abastecimento público são necessárias políticas efetivas que identifiquem, documentem e reduzam os riscos iminentes, resultantes da ocupação humana dessas bacias (Davis e Mazumder, 2003).

O gerenciamento e o tratamento de despejos gerados pela atividade humana, incluindo industrialização, agricultura e urbanização, têm sido insignificantes na prevenção à poluição de mananciais de abastecimento público, em escala local e global (Abud-Zeid, 1998).

Os autores canadenses Davies \& Mazumder (2003) consideram que todos os níveis de governo (municipal, estadual e federal) concentram a responsabilidade de estabelecer políticas para garantir a proteção de nossos recursos hídricos e prover o Estado de instrumentos para sustentá-las. As políticas de governo e de Agências Internacionais impactam diretamente o meio ambiente e a saúde humana, a economia e as facetas social e cultural de nossas vidas. O gerenciamento de recursos hídricos deve ser baseado no conhecimento científico dos riscos à saúde e ao meio ambiente, associados aos custos financeiros e à aceitação da sociedade desses riscos e custos. McKanna (2000) afirma que o Canadá é rico em recursos hídricos e sua população esta costumada com água abundante e barata. Os canadenses possuem consumo per capita de água que está entre os maiores do mundo, em contrapartida o valor pago pela água está entre os menores do mundo. Apesar de possuírem essa riqueza de recursos hídricos, os mananciais de abastecimento público estão usualmente próximos às áreas a serem supridas. Assim, os impactos da industrialização, agricultura e urbanização estão diretamente conectados com esses mananciais. Criar ferramentas sustentáveis para a utilização do ambiente e, especificamente, para a proteção de mananciais de abastecimento público, assim como assegurar saúde humana e ambiental à sociedade, são desafios a serem assumidos pelas autoridades governamentais e pela sociedade (Davies \& Mazumder, 2003)

Os desafios para alcançar a sustentabilidade de mananciais de água de abastecimento incluem reconhecer, em primeiro lugar, a lacuna de reconhecimento do papel de gerenciamento de bacias hidrográficas e, em segundo lugar, o descompasso entre gerenciadores de políticas de controle, instrumentos de controle, gerenciadores e cientistas (Davies \& Mazumder, 2003). 


\subsection{Floresta \& Água}

Segundo Lima(1996), a expressão "Influências da Floresta" (Kittredge, 1948) era utilizada para incluir o estudo de todos os efeitos resultantes da presença da floresta sobre o clima, o ciclo da água, a erosão, as enchentes, a produtividade do solo etc. Posteriormente, o desenvolvimento natural desse conjunto de conhecimentos deu lugar ao desenvolvimento da hidrologia florestal, da ecologia florestal e da meteorologia florestal.

A Hidrologia Florestal trata das relações floresta-água. É, desta forma, o ramo da hidrologia que trata dos efeitos da floresta sobre o ciclo da água, incluindo os efeitos sobre a erosão e a qualidade da água nas bacias hidrográficas. O conjunto de conhecimentos da hidrologia florestal é muito útil para nortear as atividades florestais dentro de um programa de manejo integrado de bacias hidrográficas (Lima, 1996).

A Hidrologia Florestal pode ser entendida como a área do conhecimento humano que se preocupa com o manejo ambiental da microbacia hidrográfica. Neste sentido, tendo a água como enfoque central, esta definição implica numa visão integrada ou ecossistêmica de manejo dos recursos naturais, a qual transcende aos interesses fragmentados de diferentes disciplinas e setores (Lima e Zakia, 2000).

Os dois principais problemas de conservação da água são a quantidade de água disponível e a qualidade da água para determinado fim. Os grandes avanços científicos e tecnológicos dos últimos tempos facilitaram sobremodo a tarefa do desenvolvimento e do manejo dos recursos hídricos para o benefício do homem. Embora ainda haja muito que aprender, hoje já se conhece bastante a respeito das relações de causa-e-efeito entre o homem, o ar, a água, o solo, a flora e a fauna. De modo geral, pode-se dizer que existe a tecnologia capaz de desenvolver os recursos hídricos de uma região ou de um país. Mas esse desenvolvimento não depende apenas da tecnologia. O problema é antes de tudo social, depois biológico e depois físico. O cidadão comum freqüentemente desconhece a origem de enchentes ou poluição das águas de um rio que atravessa sua cidade, que podem ter sido determinadas pelo que se sucedeu em lugar distante, mas dentro da bacia hidrográfica (Lima, 1996)

A partir do impacto inicial causado pelo desmatamento há uma ruptura no equilíbrio natural do meio, desajuste progressivamente incrementado pela 
sobreposição de formas de uso e ocupação das terras. A erosão normal, própria da evolução da paisagem, cede lugar à erosão acelerada, resposta incontinente do meio em busca de novas condições de estabilidade. Nesse contexto, dois conjuntos de fatores condicionam os processos erosivos, o natural, referenciando o meio físico por meio do clima, substrato rochoso, relevo e solo, e o antrópico, representado pelas formas de ocupação e uso das terras (Stein, 1995).

Um dos parâmetros mais importantes que caracteriza o desenvolvimento é a disponibilidade de água doce descontaminada, para consumo humano. Ainda hoje, esse acesso é negado a bilhões de cidadãos, que vivem sem acesso à água potável ou saneamento adequado. Mesmo para cidadãos que tem acesso a esse direito, o custo de manutenção da água para consumo humano vem crescendo ao longo do tempo. No século passado a população mundial triplicou, mas o uso da água cresceu seis vezes. O aumento da poluição, o crescimento da demanda, a exaustão das águas subterrâneas, a instabilidade do clima e disputas políticas têm feito da água um recurso sob ameaça. E, por ser a água um produto da natureza, proveniente de ecossistemas naturais, existe apenas uma determinada parcela da tecnologia que pode corrigir os problemas; um bom suprimento de água é resultante de equilíbrio ecológico. O papel que as florestas podem exercer, contribuindo para prover água de boa qualidade às pessoas que vivem nas grandes cidades, é uma conexão que não é simples. Florestas e sistemas de água interagem em diversas faces; essas relações são complexas e sua natureza precisão e significância permanecem no debate entre hidrólogos, economistas de recursos naturais e ecologistas (WWF \& IUCN, 2003).

A função, as definições, fronteiras e gerenciamento de áreas protegidas estão recebendo particular atenção de organizações governamentais e não governamentais, corporações e agências de desenvolvimento. Dois aspectos destacam-se nas discussões sobre áreas protegidas: a necessidade de expandir o argumento da necessidade de proteger áreas, além do foco sobre a biodiversidade e a importância de se assegurar verbas para gerenciar efetivamente áreas protegidas. A conexão entre áreas protegidas e água para abastecimento público resume-se atualmente num dos temas centrais na discussão sobre o gerenciamento de recursos naturais no mundo. A água é um forte argumento para proteção de áreas. Através do pagamento de serviços ambientais, ela pode ajudar a suprir os custos necessários para proteger áreas, se os governos introduzirem taxas para a água advinda de florestas 
protegidas pelo Estado (WWF \& IUCN, 2003). Neste caso, o estudo sugere que águas advindas de florestas protegidas e portanto, possivelmente de melhor qualidade, deveriam ter tarifa diferenciada com relação às águas de abastecimento público provenientes de mananciais menos protegidos. Esta perspectiva é interessante pois seria estabelecido um interesse econômico sobre a área de floresta conservada, criando precedentes para que em escala privada situações semelhantes pudessem ser vislumbradas como oportunidades de ganho econômico.

As inter-relações entre florestas e bacias hidrográficas são complexas e variam de acordo com a geografia, clima e manejo. Bacias hidrográficas adequadamente protegidas com florestas geralmente produzem água de melhor qualidade, resultando em expressiva redução de custos de purificação dessa água, ainda que isso dependa da extensão de níveis e tipos de contaminação (WWF \& IUCN, 2003). Esses serviços não são totalmente reconhecidos pela sociedade. A atribuição de valores econômicos aos serviços prestados pelos ecossistemas está se tornando um caminho efetivo para se compreender os múltiplos benefícios provenientes desses ecossistemas.(Guo et al., 2001).

Ao redor do mundo, as decisões econômicas sobre o uso da terra estão sendo tomadas em favor da proteção das bacias hidrográficas florestadas, visando salvaguardar o abastecimento público. A pesquisa feita por WWF \& IUCN (2003) sugere que mais de um terço das maiores cidades no mundo captam parcial ou totalmente suas águas para abastecimento público de bacias protegidas por florestas. Entre estas cidades podemos citar: Tókio, Singapura, Nova York, Bogotá, Rio de Janeiro, Los Angeles, Brasília, Viena, Barcelona, Sidnei, Melbourne.

De acordo com WWF \& IUCN (2003), uma parcela considerável da água para consumo humano vem de bacias florestadas. Essa parece ser uma clara conexão existente entre qualidade da água dessas bacias, uma conexão menos forte com a quantidade da água disponível nas bacias e uma conexão variável entre florestas(dependendo do tipo e idade) e a constância do fluxo do corpo d'água. Uma breve apreciação entre as conexões floresta e água é feita a seguir:

Conexão forte com a qualidade da água: bacias hidrográficas florestadas geralmente produzem água de ótima qualidade em oposição àquelas ocupadas por agricultura, indústria e assentamentos urbanos, que tendem a incrementar a 
quantidade de poluentes e, em alguns casos, as florestas ajudam a regular a erosão do solo e reduzir a carga de sedimentos no canal.

Conexão menos forte com a quantidade da água: a admissão da conexão entre o fluxo da água da bacia e a cobertura florestal é mais complexa. Apesar de anos de experimentos em bacias hidrográficas, a interação precisa entre diferentes espécies de árvores e idades, diferentes tipos de solo e manejo, é ainda pouco compreendida em muitas situações, tornando difícil o estabelecimento de prognósticos precisos. O impacto do uso do solo sobre o escoamento superficial depende de muitas variáveis: as características da cobertura florestal, em termos de evapotranspiração, a habilidade do solo em reter água e a habilidade da cobertura florestal em interceptar a umidade.

Conexão variável com a regularidade do fluxo de água: tão importante quanto o volume total de água é a constância o fluxo de um corpo d'água, considerando épocas de estiagem e cheia. As opiniões sobre este tema se dividem e podem ser encontrados exemplos com diferentes respostas. Em alguns casos, o fluxo d'água na estação seca decresce pela presença de árvores, enquanto em outros casos o fluxo aumenta.

Segundo Hamilton e Cassells (2003), as florestas minimizam o transporte de outros contaminantes, a erosão e o movimento de massas, reduzindo o problema de sedimentação e o carreamento ou deposição de partículas sólidas em cursos d'água. Sólidos em suspensão em águas de abastecimento ou de irrigação podem torná-las impróprias para uso, ou incrementar fortemente seus custos de tratamento. Além disso, os sedimentos podem reduzir a capacidade do canal do rio, matar ou trazer danos a peixes e a outras formas de vida aquática, interferir na navegabilidade do rio e reduzir a capacidade de armazenamento de reservatórios prematuramente. Quando a qualidade da água é necessária, as florestas são usualmente a cobertura do solo mais segura.

A proteção das zonas ripárias ao longo dos corpos d'água, nas bacias 
hidrográficas, é também de extrema importância para a conservação do sistema hídrico. Florestas intocadas ao longo desses corpos d'água, pelo menos com vinte ou trinta metros de largura podem filtrar e imobilizar sedimentos a seus compostos, reduzindo a poluição das águas. A floresta ripária também reduz a formação de bancos de sedimentos e regulam a temperatura da água (Hamilton e Cassells, 2003).

Do ponto de vista ecológico, as zonas ripárias têm sido consideradas como corredores extremamente importantes para o movimento da fauna ao longo da paisagem, assim como para a dispersão florestal. Além dessa função ecológica, as zonas ripárias têm função hidrológica fundamental de manutenção da integridade da microbacia hidrográfica. A zona ripária desempenha sua função hidrológica através da contribuição dos seguintes processos principais: geração do escoamento direto em microbacias; melhoria da qualidade da água; interação na ciclagem de nutrientes e interação direta com ecossistema aquático (Lima e Zakia, 2000).

As zonas ripárias, que incluem as áreas permanentemente saturadas das cabeceiras de drenagem e das margens dos cursos d'água, ocupam as partes mais dinâmicas da paisagem, tanto em termos hidrológicos, como ecológicos e geomorfológicos. Estas zonas ripárias estão intimamente ligadas aos cursos d'água e participam de processos vitais para a manutenção da saúde da microbacia e, conseqüentemente, dos recursos hídricos, que dizem respeito à geração do escoamento direto nas microbacias em decorrência das chuvas. Para que estas áreas críticas possam exercer esta função hidrológica de maneira eficaz, é fundamental que elas estejam adequadamente protegidas com a vegetação que normalmente se desenvolve nessas áreas, chamada de vegetação ripária, florestas beiradeiras, mata ciliar, mata de galeria etc. A mata ciliar, isolando estrategicamente o curso d'água dos terrenos mais elevados da microbacia, desempenha ação eficaz de filtragem superficial dos sedimentos, assim como reduz significativamente a chegada de herbicidas e defensivos agrícolas aos cursos d'água. Similarmente, tem também capacidade de filtrar superficial e subsuperficialmente nutrientes, que de outra forma poderiam chegar aos cursos d'água, alterando a qualidade da água. Do ponto de vista quantitativo, a destruição da mata ciliar pode, a médio e longo prazo, pela conseqüente degradação da zona ripária, diminuir a capacidade de armazenamento de água da microbacia, o que concorre para a alteração do regime de vazão dos rios (Lima, 2000).

Uma das maiores razões que tornaram tão difícil a reversão da perda 
das florestas ao redor do mundo foi o fato de que os gerenciadores de florestas recebiam muito pouco, ou nenhuma compensação, pelos serviços gerados pela manutenção da floresta. O reconhecimento desse fato encorajou o desenvolvimento de sistemas nos quais os donos das terras são compensados financeiramente pelos serviços ambientais que aquela floresta irá trazer à comunidade (WWF \& IUCN, 2003).

Os benefícios resultantes da proteção de florestas, visando a produção de água, são enormes. Um grupo de pesquisadores dos Estados Unidos, Argentina e da Holanda fixou um preço médio comum de US\$33 trilhões por ano para os serviços fundamentais prestados pelos ecossistemas mundiais. Este valor é quase duas vezes o valor do produto nacional bruto global, que é de US\$18 trilhões. Os serviços dos ecossistemas com o objetivo de regularizar a vazão e garantir qualidade no abastecimento público de água são estimados em US\$2,3 trilhões (WWF \& IUCN, 2003).

O princípio de pagamento por serviços ambientais(PES) têm ganhado força pelo mundo e trazido esperança no que diz respeito à proteção de áreas, visando seus serviços ambientais prestados, particularmente aqueles relacionados aos recursos hídricos (WWF \& IUCN, 2003).

As florestas tropicais fornecem uma variedade de serviços ambientais, indo da regularização de fluxos de vazão à conservação da biodiversidade e seqüestro de carbono. Apesar disso, uma média de quase 15 milhões de hectares de floresta por ano foi suprimida durante a década de 90, principalmente nos trópicos. Uma importante razão para essa perda é o fato de que os gerenciadores não recebem compensação financeira pelos serviços que essas florestas geram para os outros. Como conseqüência, eles têm poucos incentivos para conservá-la (Pagiola et al., 2002).

Para o desenvolvimento de um programa de compensação financeira pelos serviços ambientais prestados por uma floresta, por exemplo, são necessárias informações detalhadas sobre quais serviços são prestados por determinada floresta e quem se beneficia com eles. Muito pouco ainda é conhecido a respeito dos serviços ambientais gerados por diferentes tipos de uso da terra, embora freqüentemente avaliados, particularmente em termos de dados de quantidade (Pagiola et al., 2002).

Observando-se a bacia do rio Corumbataí, objeto de estudo neste trabalho e conforme IPEF(2001), um dos aspectos levantados pelo Plano Diretor para a Conservação dos Recursos Hídricos por Meio de Recuperação e Conservação da 
Cobertura Florestal para a bacia é de que ela deveria ter, em termos legais, cerca de $35 \%$ de cobertura florestal, representada por $20 \%$ de reserva legal e cerca de $15 \%$ de áreas de preservação permanente, representadas principalmente, pelas matas ciliares. O mapeamento da cobertura florestal atual na bacia mostrou que ela conta com 12,4\% de cobertura florestal nativa, o que significa, portanto, um déficit de cerca de $28 \%$. O Plano determinou ainda que devem ser recuperados cerca de 9.320 ha de florestas, apenas considerando as áreas de preservação permanente e se mantido o atual nível de investimento, baseado em $\mathrm{R} \$ 0,01 / \mathrm{m} 3$ de água tratada nos municípios de Piracicaba e Santa Gertrudes, conforme Programa do Consórcio de bacias dos rios Piracicaba/Capivari e Jundiaí, esse trabalho deverá demorar cerca de 118 anos, excluídas eventuais perdas de cobertura florestal resultantes de desmatamentos e incêndios florestais que venham a ocorrer nesse período. Caso o investimento aumente para $\mathrm{R} \$ 0,02$ ou $\mathrm{R} \$ 0,05 / \mathrm{m} 3$, o tempo de recuperação cairá para 59 ou 24 anos, respectivamente.

O Plano Diretor desenvolvido pelo IEPF (2001) foi um primeiro passo importante para dirigir ações e recursos financeiros, considerando-se o conhecimento do meio e as prioridades estabelecidas para recuperação de áreas. Entretanto o reconhecimento dos benefícios econômicos gerados para a sociedade usuária do recurso hídrico não era proposta de abordagem do trabalho e estes benefícios não foram determinados.

A execução de Plano Diretor dessa natureza requer verbas e comprometimento da população envolvida com a posse das terras. Importante ressaltar que a execução de plano dessa natureza deve estar acompanhada de outras ações importantes como programa de incentivo a boas práticas de uso e conservação do solo e de proteção às feições da paisagem responsáveis pelo funcionamento adequado do meio.

\subsection{Reflexos da urbanização sobre os recursos hídricos}

Regiões rapidamente urbanizadas apresentam aos gerenciadores de bacias muitos desafios, especialmente quando mananciais de abastecimento público se localizam próximos às áreas urbanas e suburbana. Esses desafios tornam-se maiores em países em desenvolvimento, onde as leis de uso do solo e proteção 
ambiental são inadequadas ou aplicadas sem rigor, resultando em uma lacuna de definições de responsabilidades institucionais e coordenação (Lee, 2000).

Lee (2000) afirma que a população no mundo é predominantemente e crescentemente urbana. Na América Latina, a taxa de urbanização é ainda crescente. Nos países mais ricos e maiores, os aglomerados urbanos e as atividades econômicas têm evoluído para uma dimensão raramente esperada na história. Esta concentração está levando a graves e negativas conseqüências ambientais, particularmente aos recursos hídricos. Segundo WWF \& IUCN (2003), atualmente metade da população mundial vive em centros e cidades e um terço dessa população urbana vive sem água limpa.

Ainda de acordo com esta referência, a despeito do crescimento da importância do uso e manejo da água urbana, as estruturas institucionais não se aprimoraram para o manejo necessário desses recursos, diante do crescimento urbano. Entretanto, recentemente, alguns países têm implementando reformas institucionais, tentando alterar a abordagem sobre o gerenciamento de recursos hídricos, incorporando mais participantes nos processos de tomada de decisão.

As cidades da América Latina, tanto as grandes e como as pequenas, possuem características na sua relação com os recursos hídricos. Em geral, há uma elevada demanda de água para uso urbano, conduzindo à exploração de recursos hídricos cada vez mais distantes, assim como a ocupação crescente de planícies de inundação, com reflexos negativos tanto para a população quanto para a dinâmica fluvial e recarga de aqüíferos e conflito crescente entre demanda da água para recreação, em corpos d'água próximos às zonas urbanas e sua poluição crescente. Ao mesmo tempo, em muitas cidades há sérias deficiências de provisão de água para abastecimento público (Lee, 2000).

Um desafio particular imposto pelo crescimento da urbanização de regiões é a freqüência crescente de múltiplos e sucessivos usos dos cursos de água. Usos sucessivos podem afetar o regime de vazões do rio e sua qualidade, tornando necessárias medidas de intervenção para controlar e regularizar os fluxos (Lee, 2000).

De acordo com Demographic Bulletin (1999), estima-se que entre os anos de 1950 e 2000 a população da América Latina e Caribe expandiu-se de 159 milhões para 500 milhões de habitantes. A taxa média de crescimento populacional atingiu o valor máximo de 2,8\% ao ano, no começo dos anos 60 . 
Ela tem declinado desde então para uma média anual de 1,46 \% e antecipa-se que ela deverá cair para menos de $1 \%$ nos próximos 25 anos. A proporção da população urbana nos anos 50 era de apenas $25 \%$, crescendo para mais de $50 \%$ na década de 80, e ultrapassando $75 \%$ nos anos 90. Durante a primeira metade do século, a expansão da população urbana era quase toda decorrente da migração, mas atualmente o principal fator de crescimento reside no próprio crescimento das populações urbanas.

Estimativas sugerem que a população mundial irá crescer em 2 bilhões de pessoas nos próximos 30 anos e mais um bilhão nos 20 anos seguintes. Aparentemente, todo esse crescimento ocorrerá em países em desenvolvimento e, principalmente, nas cidades. Uma conseqüência prevista diante de tal comportamento é a redução da média anual per capita disponível de recursos hídricos renováveis, de $6.600 \mathrm{~m}^{3}$ atuais, para $4.800 \mathrm{~m}^{3}$ para o ano de 2025. As cidades portanto, que já enfrentam tantas dificuldades de acesso à água limpa para abastecimento, devem estar preparadas para o agravamento desse problema (WWF \& IUCN, 2003). A Figura 2 demonstra a precariedade em que se encontra o abastecimento público de um segmento da população mundial.

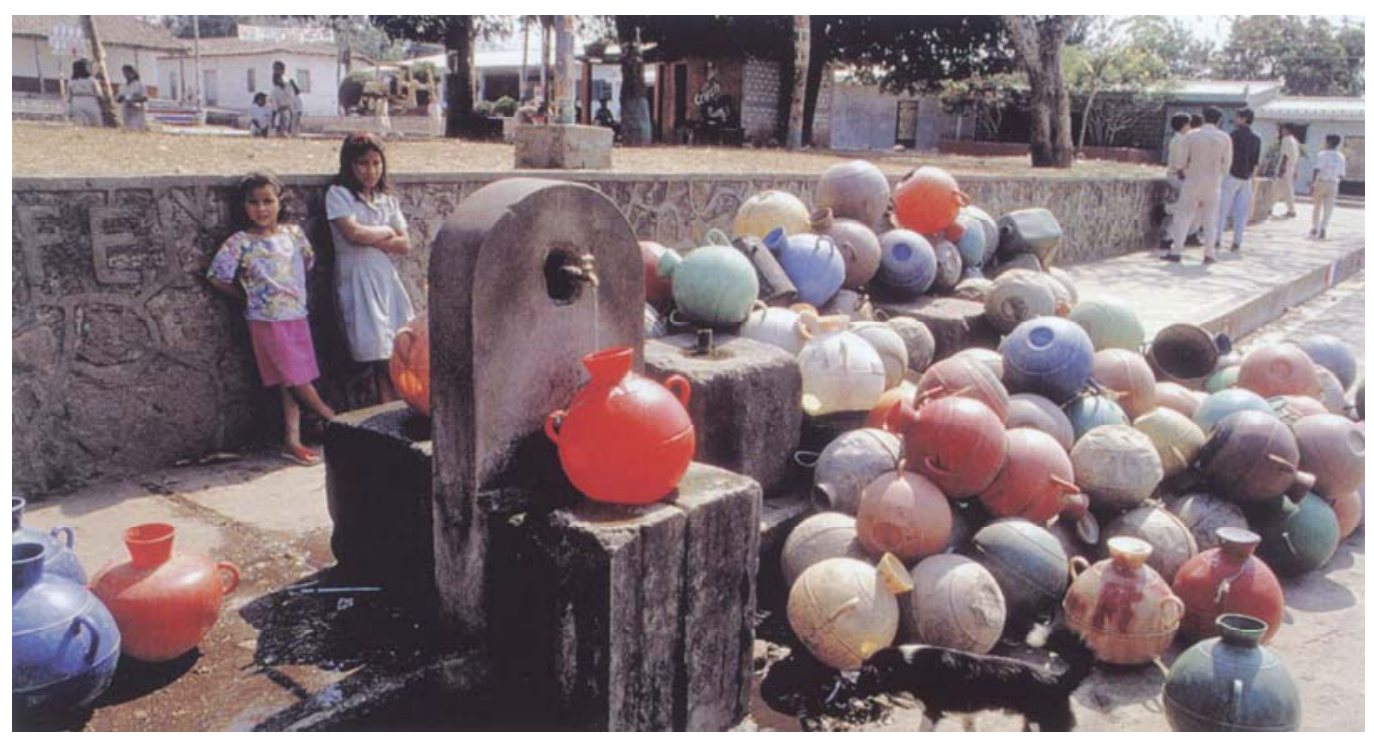

Figura 2 - Constatação da precariedade do abastecimento de cidades ao redor do mundo Fonte: WORLD METEOROLOGY ORGANIZATION (2004) 
Segundo Lee (2000), poucas cidades na América Latina possuem sistema satisfatório de coleta e disposição de esgotos. Nenhuma cidade grande trata mais de $10 \%$ de seus esgotos. É comum que rios urbanos sejam anaeróbicos e que os níveis de poluição, expressos em coliformes fecais, sejam extremamente altos em rios sob influência de áreas urbanas. Nestas áreas, o uso intensivo das águas para transporte e diluição de esgotos e a crescente urbanização nas bacias hidrográficas têm sido, para as instituições de gerenciamento de recursos hídricos, um teste difícil, para o qual a maioria delas não está preparada. O autor afirma ainda que os arranjos institucionais, apesar da distribuição clara e efetiva de responsabilidades, não são a chave para um melhor gerenciamento das águas urbanas. Um gerenciamento dinâmico somente virá com financiamento adequado. Este é o passo crucial. O financiamento adequado é o melhor indicador de um real compromisso para resolução do problema de gerenciamento de águas urbanas, tanto do setor privado quanto governamental. $\mathrm{Na}$ bacia do rio Piracicaba, a despeito dos esforços do Estado, que por volta de 1984 trouxeram escritórios de órgãos para a região, como a CETESB, o DAEE e o DEPRN, a situação de degradação dos corpos de água não se reverteu até os dias atuais. Atualmente existe a injeção de verba do Fundo Estadual de Recursos Hídricos (FEHIDRO), através de distribuição executada pelo Comitê de Bacias dos rios Piracicaba/Capivari e Jundiaí (CBH-PCJ). O financiamento no entanto não atende à demanda de investimentos necessária à reversão do quadro de degradação dos recursos hídricos da bacia.

WWF \& IUCN (2003) afirmam que os governos e conselhos municipais estão de frente da necessidade de investimentos maciços na infra-estrutura e manutenção de coleta, purificação e distribuição de água para abastecimento público. Recentemente, tem crescido o interesse por oportunidades de reduzir custos de manutenção de sistemas de abastecimento de água e de manutenção da qualidade das águas, através do manejo de recursos naturais e de florestas privadas que protegem os mananciais.

Além destas iniciativas são fundamentais outras ações como a conservação dos solos, o controle preventivo da aplicação de agrotóxicos e nutrientes na área rural, o aprimoramento no controle de emissões urbanas e industriais, o manejo adequado de áreas urbanas, minimizando a drenagem de resíduos para os cursos d'água. 


\subsection{Impactos decorrentes da atividade humana e suas conseqüências para os sistemas aquáticos}

Os vastos recursos hídricos do Brasil têm grande significado ecológico, econômico e social. O gerenciamento, a conservação e recuperação desses sistemas são, portanto, de importância fundamental, com reflexos na economia, na área social e nos usos dos sistemas aquáticos. Este gerenciamento é muito complexo, dependendo de uma forte base de dados e de desenvolvimento de mecanismos de transferência do desenvolvimento científico básico para a aplicação (Tundisi et al, 1999). Estes autores ressaltam que a exploração dos recursos hídricos para a produção de energia, biomassa e irrigação e suprimento da água para os municípios demanda uma forte articulação entre a base de pesquisa e conhecimento científico acumulado, e as ações de gerenciamento e engenharia. Sem essa articulação que leve em conta qualidade e quantidade da água, muito pouco avanço conceitual pode ser alcançado. Além disso, deve-se considerar o uso da unidade em estudo (bacia hidrográfica, rio, lago ou reservatório). Sem este conceito há pouca probabilidade de um gerenciamento efetivo do sistema.

Os mesmos autores classificam os principais impactos resultantes da atividade humana nos recursos hídricos nas seguintes categorias: desmatamento, mineração, construção de rodovias e ferrovias, despejo de material residual, introdução de espécies exóticas, remoção de espécies críticas e construção de reservatórios. Seria relevante acrescentar a essas categorias mencionadas, a expansão urbana indiscriminada. As principais conseqüências dos impactos listados foram classificadas como: eutrofização, aumento do material em suspensão e assoreamento, perda de diversidade biológica, alterações no nível da água e no ciclo hidrológico, perda da capacidade tampão, expansão geográfica de doenças tropicais de veiculação hídrica e toxicidade. A seguir serão descritas as conseqüências e alguns desses impactos:

Eutrofização - O resultado das inúmeras descargas de águas poluídas, com alta concentração de Nitrogênio e Fósforo. A eutrofização acelera o aumento de matéria orgânica nos sistemas, produz concentrações indesejáveis de fitoplâncton e macrófitas aquáticas e promove o aumento de doenças de veiculação hídrica. 0 
desenvolvimento das atividades humanas nas bacias hidrográficas tem aumentado as funções de transferência de sistemas terrestres para sistemas aquáticos. O acúmulo de Fósforo no sedimento é comum.

Aumento do material em suspensão e assoreamento - O uso inadequado do solo e práticas agrícolas inadequadas, produzem um enorme impacto nos sistemas aquáticos. Há um aumento considerável do material em suspensão na água com as seguintes conseqüências: redução da zona eutrófica; redução da concentração de oxigênio dissolvido; redução da produção primária de fitoplâncton; mortalidade em massa de macrófitas e peixes. Além disso, ocorre um assoreamento rápido dos leitos, diminuindo a capacidade de armazenamento subseqüente dos corpos hídricos.

Alterações no nível da água e no ciclo hidrológico - Uma das conseqüências mais drásticas das modificações produzidas pelos impactos causados pela interferência antrópica é a diminuição da altura do nível da água com efeitos nos rios, lagos adjacentes e lagoas marginais, nas águas subterrâneas e florestas ripárias ao longo de rios e áreas alagadas.

Perda da capacidade tampão - Áreas alagadas, florestas ripárias, interfaces entre sistemas terrestres e aquáticos, são regiões tampão que removem nitrogênio (por desnitrificação) e fósforo (por precipitação e complexação no sedimento e agregado em partículas às raízes de macrófitas). Além disso, precipitam metais pesados e complexam estes elementos; removem material em suspensão, impedindo seu transporte para sistemas aquáticos.

Toxicidade - Não basta que uma população disponha de água em quantidade; é necessário que essa água se caracterize por um determinado padrão de qualidade. Os padrões de qualidade da água referem-se a um certo número de parâmetros capazes de refletir, direta ou indiretamente, a presença efetiva ou potencial de algumas substâncias ou microrganismos que possam comprometer a qualidade da água do ponto de vista de sua estética e de sua salubridade. São inúmeros os componentes químicos e as espécies microbiológicas que podem comprometer, tanto o aspecto estético das águas, quanto o sanitário. A determinação de cada um deles, por meio de procedimento analítico chega, pois, a tornar-se inviável, se considerarmos o crescente número de produtos sintéticos de uso industrial, agrícola, pecuário ou sanitário, que, através dos efluentes dessas atividades, podem atingir um manancial. $\mathrm{O}$ 
mesmo se pode dizer com relação aos organismos patogênicos que, embora ainda não constituam produtos de síntese, ainda não são todos bem conhecidos, particularmente os vírus. Assim, a análise sistemática de todos os contaminantes possíveis vem se tornando cada vez mais difícil, onerosa e, portanto impraticável (Branco, 1999).

Burby et al (1983) identificam 5 classes de materiais contaminantes para águas de abastecimento público, conforme definido pela National Academy of Sciences Committee on Safe Drinking Water nos Estados Unidos:

Contaminantes biológicos - Os contaminantes biológicos em águas incluem bactérias, vírus, protozoários, fungos e algas. Bactérias, protozoários patogênicos e vírus podem provocar doenças. Desde 1971, notou-se um notável crescimento em infecções veiculadas pela água. Possíveis razões apontadas para esse crescimento são: 1) aumento de relatos sobre eclosão de doenças de veiculações hídricas; 2) uma sobrecarga sobre os sistemas de tratamento que a cada vez recebem águas de mananciais de pior qualidade; 3)processos de tratamento de água que não removem vírus ou protozoários.

Material particulado em suspensão - Material particulado que não se dissolve em água pode ser orgânico ou inorgânico. Os sólidos insolúveis podem ser derivados de solos e rochas, mas eles também resultam de processos de manufatura. Estes contaminantes incluem: argila, partículas fibrosas e partículas orgânicas, provenientes da decomposição de plantas e fragmentos de animais no solo. Ainda que a argila e partículas orgânicas originárias da natureza possam não ser nocivas, esses sólidos podem carrear substâncias químicas, nutrientes e metais pesados. Além disso, a sedimentação em reservatórios de abastecimento, limitando sua capacidade de estoque, é ocorrência que pode ter impactos futuros, com o crescimento populacional. A capacidade dos sólidos de absorver poluentes foi designada como a maior classe poluente nos Estados Unidos.

Sólidos inorgânicos dissolvidos - Esta classe refere-se aos metais pesados e outros elementos inorgânicos dissolvidos em águas de abastecimento. Há uma crescente preocupação com águas ricas em metais pesados. As partículas precipitadas podem ser absorvidas pelas partículas de argila em suspensão.

Sólidos orgânicos dissolvidos - Contaminantes orgânicos incluem: pesticidas, uma variedade de compostos orgânicos tais como, clorofórmio, benzeno, nicotina, cloretos e nutrientes como o nitrogênio e o fósforo. Ainda que os compostos 
orgânicos sejam freqüentemente medidos nas águas de abastecimento público, apenas uma fração destas espécies foi identificada pela ciência. Mais de 423 substâncias químicas orgânicas têm sido identificadas em águas brutas e 325 destes compostos foram encontrados em água tratada. Efeitos carcinogênicos desses compostos orgânicos encontrados em águas de abastecimento público representam séria ameaça à saúde humana. Processos de tratamentos convencionais são parcialmente efetivos na remoção de contaminantes orgânicos e mesmo processos avançados, como a adsorção utilizando-se carvão ativado, não asseguram que todos os traços de compostos químicos tenham sido removidos. Ademais, tecnologia para o contínuo monitoramento destas substâncias químicas não está disponível, assim a determinação de sua presença e remoção são de difícil execução.

Dentre os impactos sobre os recursos hídricos relacionados à atividade humana, tanto sob o ponto de vista de dimensionamento quanto de controle da poluição, as fontes difusas de poluição têm importância inquestionável.

Desde o início dos anos 80 , as fontes de poluição difusa têm sido reconhecidas como fontes significativas para os problemas encontrados na qualidade das águas superficiais. A mais significativa destas fontes são os sedimentos produzidos pela erosão do solo, principalmente decorrentes das ações antrópicas. Atividades como agricultura, urbanização e sistemas viários intrínsecos, mineração, desmatamento e colheita florestal aceleram as taxas naturais de erosão, aumentando o carreamento de sedimentos para as águas superficiais (Nelson \& Booth, 2002).

Os sedimentos finos e grossos transportados pelas águas superficiais podem resultar em diferentes tipos de problemas. Os sedimentos finos geralmente causam problemas na qualidade da água em canais ou em corpos receptores. Além da preocupação com o problema da turbidez, outros poluentes de fontes difusas, tais como nutrientes e metais pesados, podem formar complexos com os minerais argilosos formadores do sedimento fino, contribuindo para a eutrofização de lagos e a toxicidade para organismos aquáticos (Novotny e Olem, 1994). Os sedimentos grossos não elevam as preocupações sobre contaminações químicas decorrentes da sua presença na água, mas podem causar assoreamento de canais, resultando em redução da capacidade de vazão, que pode levar a inundações, problemas de navegação, instabilidade do canal e comprometimento da vida aquática (Nelson e Booth, 2002).

$\mathrm{Na}$ bacia Issaquah Creek, de $144 \mathrm{Km}^{2}$, no lado oeste do Estado de 
Washington, EUA, com particular grau de desenvolvimento urbano, a atividade humana tem causado um incremento de cerca de $50 \%$ no sedimento produzido a cada ano. As principais fontes de geração de sedimentos são deslizamento de terra (50 \%), erosão de canais (20 \%) e erosão de superfícies de estradas (15 \%) (Nelson e Booth, 2002).

Segundo Long, 1991 citado por Randhir et al. (2001), se por um lado houve sucesso no controle de fontes pontuais de poluição, as fontes difusas de poluição ou nonpoint source (NPS) ainda representam a maior ameaça aos cursos d'água. Esse é o maior desafio a ser enfrentado pelas instituições e sociedade em razão da complexidade natural e da existência de diversas e difusas áreas contribuintes ao longo da bacia e seus diferentes usos.

Randhir et al. (2001) ressaltam que as duas maiores características da poluição por fontes difusas são os múltiplos efeitos a ela associados e a dimensão destes efeitos ao longo do tempo e do espaço. Os múltiplos efeitos de poluição difusa incluem: eutrofização em cursos de água, prejuízos em ecossistemas aquáticos e terrestres, estações de tratamento de água sofisticadas, custos de recuperação, mananciais de abastecimento público de baixa qualidade, declínio do uso para recreação dos mananciais e alteração nas vazões dos rios. Soluções para a poluição causada por fontes difusas incluem medidas preventivas e de restauração, usando medidas estruturais e não estruturais. Considerando-se uma comparação entre os custos relativos ao tratamento da água e aqueles referentes à recuperação de áreas e medidas preventivas aplicadas na unidade da bacia hidrográfica, os custos referentes às medidas preventivas serão mais vantajosos em termos econômicos.

Até muito recentemente, os métodos de avaliação da qualidade das águas dominantes eram baseados em análises químicas e físicas da água. Estudos têm apontado que impactos biológicos resultantes de fontes de poluição difusa e degradação do habitat não têm sido representados pelas análises físico-químicas periodicamente realizadas nos cursos d'água (Wang 2001). Segundo Karr e Dudley (1981), avaliações da qualidade da água que utilizam indicadores biológicos baseiamse na premissa de que um corpo d'água com integridade biológica deve ser capaz de manter uma comunidade de organismos adaptada e integrada, com diversidade de espécies e organização funcional comparáveis àquelas existentes em habitat natural . Wang (2001) afirma que os corpos d'água que têm sido impactados por atividades humanas devem demonstrar alteração na sua integridade biológica. Em 1990, a 
Agência de Proteção Ambiental Americana (USEPA) publicou manuais para que as agências estaduais de proteção ambiental desenvolvessem e implementassem avaliações biológicas de águas superficiais, o que passou a ocorrer em vários ambientes aquáticos.

Wang (2001) afirma que a industrialização e a urbanização têm trazido prosperidade e, ao mesmo tempo, resultado em muitos problemas ambientais. Reconhece-se que a qualidade das águas dos corpos receptores de uma bacia hidrográfica é afetada pelas atividades humanas por fontes pontuais e difusas, tais como o escoamento superficial de áreas urbanas e de áreas rurais. De acordo com o mesmo autor, ainda que os pesquisadores venham prestando particular atenção aos efeitos do uso da terra sobre a qualidade das águas, o componente que se refere exatamente à qualidade das águas raramente é observado nos planos de uso do solo e o planejamento de uso do solo dificilmente é utilizado no gerenciamento da qualidade das águas. Pode ser que isso ocorra exatamente pelo fato de serem, o gerenciamento da qualidade das águas e o planejamento do uso do solo, freqüentemente coordenados por agências diferentes. A maioria das agências de planejamento e autoridades locais não tem recursos para obter dados sobre uso do solo e qualidade da água nas etapas de desenvolvimento dos planos; as agências de gerenciamento da qualidade das águas tradicionalmente reconhecem e pontuam os problemas de qualidade, ao invés de prevení-los.

A situação que Wang (2001) coloca reflete a realidade dos municípios e instituições paulistas de gerenciamento ambiental. O gerenciamento da qualidade das águas está subordinado à Secretaria do Meio Ambiente e o planejamento do uso do solo, apenas às Prefeituras municipais, às quais rotineiramente não possuem Planos de uso e ocupação do solo. O diagnóstico da situação dos recursos hídricos tem atualmente pouca relação com a priorização de ações estabelecida pelos órgãos ambientais. 


\title{
2.5 Efeitos dos poluentes e reflexão sobre tratamentos mais utilizados para águas de abastecimento público
}

\begin{abstract}
Segundo Hespanhol (1999), o desenvolvimento da tecnologia de tratamento de águas, ocorrido na segunda metade deste século, levou à aceitação indiscriminada da idéia de que os mananciais que recebem efluentes industriais contendo micro-poluentes sintéticos, orgânicos e inorgânicos, poderiam ser convenientemente tratados, permitindo a produção de uma água absolutamente segura. Independentemente dos níveis de poluição desses mananciais, acreditava-se que os processos e operações unitárias de coagulação-floculação, sedimentação, filtração e desinfecção, seriam suficientes para tornar a água segura para abastecimento doméstico, eliminando os agentes etiológicos causadores das doenças contagiosas transmitidas pela água, que eram àquela época, a principal preocupação de saúde pública associada ao abastecimento público.

Entretanto, ainda conforme o mesmo autor, como conseqüência da revolução química, que, logo após a Segunda Guerra Mundial, introduziu na sociedade, no ambiente e nos corpos de água superficiais e subterrâneos milhares de compostos orgânicos sintéticos, surgiram os riscos de doenças crônicas associados às concentrações muito baixas de micro poluentes, orgânicos e inorgânicos, que não são absolutamente removidos através de sistemas convencionais de tratamento, como os acima mencionados.

Em 1962, com o livro Primavera Silenciosa, Rachel Carlson já fazia advertências como: "Desde que se iniciou a fabricação de substâncias que a natureza nunca inventou, o problema da purificação da água se tornou complexo e aumentaram os perigos associados à sua utilização. A produção dos compostos sintéticos em larga escala começou em 1940. Desde então um terrível dilúvio de poluentes químicos é, diariamente, despejado em nossos corpos de água. Quando intimamente misturados com esgotos domésticos e outros tipos de efluentes, esses compostos químicos desafiam a detecção através dos métodos normalmente utilizados em estações de tratamento. A maioria deles é tão estável que não pode ser decomposta através de processos convencionais. Freqüentemente eles não podem nem ser identificados.".
\end{abstract}


O Congresso Americano, preocupado com a presença de contaminantes orgânicos na água potável e a errática - freqüentemente ineficiente - supervisão governamental dos serviços públicos de abastecimento de água, aprovou em 1974 o Safe Drink Water Act, através de Lei Pública. A partir desta legislação, padrões provisórios para água potável foram estabelecidos em 1975 e revisões foram efetuadas em 1976, 1979, 1980 e 1986. A Academia Nacional de Ciências efetuou uma avaliação dos padrões estabelecidos, publicados em 1980, colocando em evidência não apenas os elevados riscos associados aos micro poluentes orgânicos, mas também a quase absoluta ineficácia, àquela época nos Estados Unidos, dos sistemas de monitoramento utilizados para garantir que águas extraídas de mananciais poluídos por efluente de grandes parques industriais, possam ser utilizadas como fontes de água potável. Uma das mais importantes conclusões da Academia foi que apenas 10\% em peso dos compostos orgânicos presentes na água potável foram identificados até o presente e, entre esses, apenas alguns tiveram suas características toxicológicas determinadas. Como conseqüência dessa insegurança, vem ocorrendo um aumento significativo do número de parâmetros necessários para regulamentação. Em 1925 eram 10 parâmetros, em 1974, quando a vigilância sobre a água potável foi atribuída à USEPA(Agência de Proteção Ambiental Americana), esse número já era superior à 20 e hoje está próximo de 130. A tendência provável é que, em torno do ano 2010, aproximadamente 200 parâmetros estarão sendo regulamentados nos EUA, o que não assegurará, absolutamente, que se disporá de uma água tão segura como aquela disponível em 1925, que era caracterizada por uma quantidade irrisória de parâmetros (Hespanhol, 1999).

Conforme relaciona ainda o mesmo autor, são diversos os efeitos adversos que podem ser causados pela presença de pequenas doses de compostos químicos na água, podendo ser resumidos nos seguintes:

- Tóxicos: causando efeitos danosos a quaisquer sistemas biológicos, injuriando seriamente qualquer função biológica, ou produzindo a morte. Esses efeitos podem resultar de condições agudas(exposição de curto prazo a uma dosagem elevada), condições crônicas(exposição de longo termo a doses muito baixas), ou condições subcrônicas (doses e períodos de exposição intermediários).

. Neurotóxicos: exercendo um efeito destrutivo ou tóxico no tecido nervoso. 
- Carcinogênico: causando ou induzindo crescimento descontrolado de células anômalas, vindo a provocar tumores malignos.

- Mutagênicos: causando alterações hereditárias do material genético das células;

· Tetragênicos: causando deformações congênitas não hereditárias em fetos.

Hespanhol (1999) faz uma reflexão sobre a necessidade de se atualizar o conceito de tratamento de águas de abastecimento público no Brasil. Tal constatação é mesmo premente, diante da grande quantidade de captações existentes em mananciais superficiais, que recebem volumes elevados de esgotos industriais e domésticos.

Reforçando a posição de que o tratamento convencional é insuficiente para levar água de qualidade à população, quando o manancial de abastecimento recebe contribuição elevada de esgotos urbanos e industriais, Batalha (1998) afirma que "O sistema de tratamento convencional de águas para abastecimento público baseia-se nas técnicas de floculação, sedimentação, filtração e desinfecção. Esse conjunto de operações produz uma água aceitável aos sentidos humanos e livre de microrganismos patogênicos - incapaz, portanto de ter efeitos agudos sobre a saúde da população. Esse tratamento convencional, no entanto, exige que os mananciais sejam de boa qualidade, apresentando padrões estéticos e sanitários compatíveis com as técnicas utilizadas, e que o residual de cloro seja mantido ao longo do sistema de distribuição da água. Os critérios de qualidade fixados para os mananciais incluem colimetria e análise dos aspectos físico-químicos. Quase nunca se avalia como as substâncias químicas interagem e os eventuais riscos dessa interação, o que poderia indicar se os métodos convencionais são de fato suficientes para tratar a água para consumo humano. A constante expansão das atividades humanas vem introduzindo nos corpos d'água certos tipos de substâncias químicas que tendem a se associar aos materiais em suspensão e em solução e a se acumular nos sedimentos depositados no fundo. Tais substâncias podem contaminar organismos que vivem na coluna d'água ou no fundo e assim entrar na cadeia alimentar. Por isso a sociedade, sem esquecer a preocupação de atender aos padrões estéticos e à descontaminação biológica, deve adotar ações que limitem os novos riscos à saúde pública: os efeitos crônicos da contaminação ambiental." 
A qualidade da água tratada depende das características do manancial que a fornece, pois as quantidades de compostos químicos tóxicos, sejam de origem química ou biológica, dificilmente são removidas pelas técnicas convencionais de tratamento (Batalha,1998).

\subsection{Saúde da população e qualidade da água \& riscos e custos envolvidos}

De acordo com Crouch et al (1983), os padrões vigentes de potabilidade da água não estão diretamente relacionados com riscos à saúde conhecidos; usualmente o risco de câncer é a maior preocupação no estabelecimento de diretrizes para baixos níveis de compostos orgânicos e quase sempre as estimativas de risco de câncer são feitas em uma atmosfera de incertezas. Durante alguns anos foram desenvolvidos procedimentos que consideram as incertezas envolvidas nesses cálculos de risco, de forma que esses riscos fossem determinados com maior precisão. Os autores ilustram o trabalho com o cálculo desses riscos para algumas amostras de águas de abastecimento público dos Estados Unidos. Eles afirmam que a exposição, em níveis baixos, de compostos orgânicos encontrados em água potável pode causar uma variedade de efeitos à saúde, estando o câncer entre as maiores preocupações. A estimativa do risco de câncer é incerta, o que pode, em parte, explicar a razão pela qual o risco de câncer não é corretamente considerado no estabelecimento de padrões de potabilidade de água.

Segundo os autores Davies \& Mazumder (2003), a relação entre a fonte de água superficial de abastecimento e a qualidade da água tratada, de forma simplista, é que fontes mais limpas de água requerem tratamento de água menos intenso e têm menores riscos associados à saúde humana, agudos ou crônicos. Os agentes e processos associados à qualidade das águas de abastecimento público e à saúde da população podem ser classificados como:

\section{a) Organismos Patogênicos}

As infecções provocadas por bactérias patogênicas, protozoários e vírus prevalecem mundialmente na associação de riscos à saúde e água para consumo 
humano. Os organismos mais comuns encontrados em águas para abastecimento público, que representam as maiores ameaças para a saúde incluem: (1) bactérias: Escherichia coli, Vibrio cholerae, Shigella, Campylobacter jejuni, Salmonella, Yersinia enterocolitica, (2) protozoários: Giárdia lamblia, Cryptosporidium parvum, Entamoeba histolytica, Toxoplasma gondii, Balantidium coli, e (3) vírus: Norwalk and Norwalk-like, Rotavirus, Hepatitis A e E (Matsunaga and Okochi, 1998 citado por Davies \& Mazumder, 2003; Ford and Mac Kenzie, 2000).

b) Desinfecção e organismos patogênicos resistentes à desinfecção

Em nações desenvolvidas, os riscos à saúde provenientes de organismos patógenos têm sido amplamente mitigados através da desinfecção da água potável. A desinfecção é realizada por algumas formas de cloração, ozonização e, mais recentemente, radiação ultravioleta. A filtração é freqüentemente utilizada anteriormente à desinfecção, para remover partículas e patógenos através de processo físico (Davies \& Mazumder, 2003).

A despeito dos benefícios da desinfecção, muitos organismos patogênicos são resistentes ao processo de cloração tradicional. Dois desses organismos patogênicos, Cryptosporidium e Giárdia, têm sido objeto de pesquisa nos últimos dez anos, já que seus cistos não são inativados por cloração ou ozonização e nem são completamente removidos por filtração. Eles possuem também baixa dose para gerarem processo infeccioso e são comuns em águas superficiais. Em Milwaukee, Estados Unidos, em 1993, 400.000 pessoas ficaram doentes e mais de 100 pessoas morreram após serem infectadas pelo Cryptosporidium, proveniente das águas de abastecimento público (Davies \& Mazumder, 2003).

Davies \& Mazumder (2003) relataram que num universo de quatro bacias hidrográficas estudadas em British Columbia, as águas para abastecimento provenientes de bacia florestada e protegidas do acesso do público tiveram a menor concentração de cisto de Giárdia, enquanto a concentração de cistos em outra bacia com atividade agrícola predominante foi ligeiramente superior.

c) Subprodutos de desinfecção

Enquanto os riscos de infecções agudas são significativamente reduzidos pelos processos de desinfecção (cloro, cloraminas, dióxido de cloro, ozônio), 
o desinfetante reage com compostos orgânicos, presentes na água, para produzir compostos secundários conhecidos como DBPs. Davies \& Mazumder (2003) dividem os DBPs em três categorias principais: (1) substâncias que podem causar efeitos tóxicos, carcinogênicos ou efeitos genotóxicos; (2) carbono orgânico assimilável, que estimula o crescimento bacteriano em sistemas de distribuição de água; (3) compostos que conferem gosto e odor. Numerosos DBPs têm sido identificados. Os mais conhecidos e estudados são os Trialometanos Totais (TTHM - incluindo: clorofórmio, bromo-diclorometano, di-bromoclorometano e bromofórmio) e ácidos haloacéticos. Desde que os Trialometanos (THMs) foram descobertos em águas de abastecimento cloradas, as pesquisas têm investigado os problemas potenciais de saúde associados com esses compostos. A concentração de TTHMs em águas tratadas é função da temperatura, da demanda de cloro, da concentração de carbono orgânico total e do tempo de contato. Os mananciais de abastecimento com menos carbono orgânico são considerados de melhor qualidade, pois elas terão menor demanda de cloro e menor DBPs serão formados com a água tratada .

d) Contaminação química

Davies \& Mazumder (2003) argumentam que o uso de produtos químicos e sua introdução no meio ambiente resulta na mais óbvia alteração/contaminação de águas superficiais. Dos produtos químicos listados no Canadian Drinking Water Guidelines, a maioria é usada na agricultura ou na indústria.

Os mesmos autores enfatizam que nutrientes inorgânicos provenientes de fertilizantes, especialmente nitrogênio e fósforo, podem estimular a produtividade aquática, resultando em ambientes eutrofizados. A eutrofização resulta em condições desfavoráveis à qualidade da água incluindo: alta concentração de carbono orgânico dissolvido, aumento do número de bactérias, crescimento de algas, gosto e odor indesejáveis e mudanças na cadeia alimentar e na composição de espécies de peixes .

As algas e os blooms de algas são importantes precursores de produção de THM. Estudos correlacionando algas e Carbono Orgânico Dissolvido (COD) com THMs demarcam a conexão crítica entre a qualidade dos parâmetros da fonte de abastecimento e os riscos à saúde (Davies \& Mazumder, 2003).

e) Cianobactérias 
A abundância de cianobactérias ou algas azuis em mananciais de abastecimento público é um importante tema relacionado à saúde. Por séculos, os blooms de cianobactérias estavam associados com a má qualidade das águas. Entretanto, apenas há algumas décadas atrás começou a ser compreendida e apreciada a importância de toxinas e a produção de gosto e odor características dessas algas. As cianobactérias são conhecidas por produzir hepatoxinas, neurotoxinas, citotoxinas, distúrbios gastrointestinais e respiratórios e reações alérgicas (Davies \& Mazumder, 2003). Batalha (1998) afirma que é grande o volume de informações científicas sobre os efeitos em curto prazo ou agudos de altos níveis de contaminantes, mas o mesmo não ocorre com os efeitos crônicos. Na verdade pouco se sabe sobre o que acontece a seres humanos expostos a baixas concentrações de compostos químicos por 20 ou 30 anos.

O ambiente e a saúde humana estão indiscutivelmente conectados. A degradação e a negligência ambientais podem resultar em problemas agudos e crônicos de saúde. Os guias que definem padrões para águas de consumo humano estão baseados no melhor conhecimento disponível da ciência, entretanto esta área da ciência é complexa. A previsão e implementação do gerenciamento de mananciais de abastecimento público têm a importância de reduzir significativamente custos e riscos associados às águas de abastecimento público (Davies \& Mazumder, 2003).

O risco à saúde associado à água para consumo humano pode ser reduzido à seguinte equação: risco é igual à probabilidade de um evento ocorrer multiplicado pela conseqüência (efeito medido).

A comunidade e os governantes precisam avaliar suas prioridades e balancear riscos e custos, quando do desenvolvimento de políticas de estabelecimento de fontes de abastecimento público. O potencial econômico de custos associados com a veiculação de doenças pela água de consumo humano está relatado no artigo de Livernois (2002) citado por Davies \& Mazumder (2003), com relato de uma epidemia de E. coli em Walkerton, Ontário, que resultou na morte de sete pessoas e 2.300 outras doentes. Nessa pequena comunidade canadense o impacto econômico foi estimado em $\$ 64,6$ milhões.

Os mesmos autores ressaltam que os riscos à saúde pública em bacias hidrográficas sem proteção são considerados maiores do que naquelas protegidas. Os riscos incluem a introdução de produtos químicos e nutrientes; esgotos urbanos e 
fluxos provenientes da agricultura; sedimentos provenientes de carreamento do solo e de construção de estradas. A disposição de produtos químicos carcinogênicos, mutagênicos e tóxicos aumentam o risco de problemas de saúde a longo prazo.

De acordo com Salati et al (1999), o Banco Mundial em seu relatório intitulado Gerenciamento de Recursos Hídricos e publicado após a Conferência do Rio de Janeiro de 1992, alerta para a perspectiva difícil do aproveitamento de novas fontes de suprimento a partir de águas superficiais para atender à demanda crescente, em virtude dos custos de construção cada vez maiores, da acirrada oposição dos ambientalistas e dos limitados recursos disponíveis. Uma análise realizada em 1992 pelo mesmo Banco Mundial, para financiamento de projetos de abastecimento público de água, mostrou que o custo de cada metro cúbico de água dos futuros projetos tende a ser duas ou três vezes maior que o custo do metro cúbico dos projetos que estão sendo desenvolvidos atualmente. A justificativa relatada, conforme Salati et al (1999), "reside no fato de que as fontes de águas superficiais disponíveis estarão cada vez mais distantes, exigindo obras de grande porte e tecnologicamente mais complexas, como transposição de bacias, o que implica em maior impacto sobre o meio ambiente e, conseqüentemente, maior oposição dos ambientalistas".

Holmes (1988), citado por López (1997), analisou os efeitos da erosão do solo sobre os custos do tratamento da água para uso domiciliar nos Estados Unidos. O autor relacionou o custo operacional e de manutenção total com a quantidade de água potável produzida, a turbidez da água bruta e os preços do trabalho e da eletricidade. Isso para determinar o efeito marginal da turbidez da água bruta sobre o custo do tratamento. Posteriormente, estimou-se o efeito marginal da erosão do solo sobre a turbidez da água bruta para, finalmente, se obter o efeito marginal da erosão do solo sobre o custo do tratamento de água. Os resultados indicaram que o aumento de $1 \%$ da carga de sedimentos produzida pela erosão do solo causa um acréscimo de 0,05 \% nos custos de operação e manutenção. Com esse resultado, estimou-se que, em média, o custo aumenta em US\$17,11 para cada mil toneladas de sedimentos. A estimativa do custo adicional causado pelos sedimentos em suspensão na água, para a totalidade dos Estados Unidos, ficou entre US\$ 35,3 milhões e US\$ 661,2 milhões anuais.

López (1997) determinou os custos privados e sociais da erosão do solo na bacia hidrográfica do rio Corumbataí e, em média, o custo operacional adicional da 
ETA seria de $R \$ 3,21$ / ha por ano e $R \$ 0,10$ / t de solo erodido ( $R$ \$ de dezembro de 1995). O trabalho estudou dados operacionais da ETA Capim Fino, que trata as águas do rio Corumbataí entre os anos de 1985 e 1994. Nesse período, ficou demonstrada uma tendência de crescimento do custo operacional adicional causado pela erosão.

López (1997) definiu como custo total da erosão do solo na bacia do rio Corumbataí, o custo interno (perda de produtividade e de nutrientes) da propriedade rural com cana-de-açúcar decorrente da erosão do solo somado ao custo operacional adicional do tratamento de água (um dos custos externos), causado pela erosão do solo na bacia. O trabalho conclui que se fossem observados e respeitados os limites máximos toleráveis de erosão, os custos internos causados pelas perdas de solo seriam reduzidos em $87 \%$. Se houvesse um programa de conservação de solos na bacia visando atingir níveis de perdas de solo iguais ou menores aos limites toleráveis, isso representaria um custo anual para o produtor de $\mathrm{R} \$ 70,50$ / ha / ano.

López (1997) defende ainda a tese de que o custo interno representa 96,2 \% do custo da erosão do solo na bacia. Assim sendo, não se justificaria a intervenção governamental na implantação de programas de conservação de solos, porque ela não seria econômica para a sociedade. A conservação de solos ficaria em mãos dos produtores que a empreenderiam, na medida em que ela fosse econômica para eles.

Diante da existência da Lei Estadual nº 6171 de 1988, alterada pela Lei Estadual no 8421 de 1993, que dispõe sobre o uso, conservação e preservação do solo agrícola, a afirmação do autor no parágrafo anterior causa estranheza, pois o produtor rural deve exercer em sua propriedade uso adequado do solo agrícola, entendendo-se que se trata de "... a adoção de um conjunto de práticas e procedimentos que visem à conservação, melhoramento e recuperação do solo agrícola, atendendo à função sócio-econômica da propriedade rural da região.". Assim, o ônus do uso de práticas de cultivo inadequadas deve recair efetivamente sobre o proprietário rural.

Em termos médios, o custo resultante da erosão do solo na bacia do rio Corumbataí atingiu $\mathrm{R} \$ 84,54$ / ha lano e o custo tolerável ( custo de intensidade máxima de erosão do solo que permite a um elevado nível de produtividade manter-se econômica e indefinidamente) resultante da erosão era de $\mathrm{R} \$ 13,76$ / ha /ano. Isto significa que o benefício total médio de um programa de conservação que conseguisse 
restringir perdas de solo por erosão aos seus limites máximos toleráveis seria de $\mathrm{R} \$$ 70,78 / ha / ano. Isto supondo que o único efeito externo causado pela erosão fosse o aumento do custo de tratamento de água para abastecimento público.

Observa-se que no trabalho de López (1997) não foi considerado qualquer custo referente ao assoreamento dos leitos dos rios, alagamentos de áreas próximas aos leitos, perda de navegabilidade, perda de diversidade de organismos aquáticos, em decorrência do carreamento de sedimentos aos leitos.

Atenta para o crescente comprometimento dos mananciais de abastecimento público, as autoridades sanitárias avançaram com a entrada em vigor da Portaria Federal do Ministério da Saúde 1469, em Janeiro de 2003, substituída com pouquíssimas alterações pela Portaria 518 de 2004. A Portaria versa sobre a qualidade da água de mananciais de abastecimento público. Esta Portaria estabelece os procedimentos e responsabilidades inerentes ao controle e vigilância da qualidade da água para consumo humano e estabelece seu padrão de potabilidade, e dá outras providências. Ela define a responsabilidade do governo federal em controlar a qualidade da água para consumo humano por intermédio da Secretaria de Vigilância em Saúde (SVS), promovendo e acompanhando a vigilância da qualidade da água, em articulação com as Secretarias de Saúde dos Estados e do Distrito Federal e com os responsáveis pelo controle de qualidade da água.

Aos governos estaduais e ao Distrito Federal compete principalmente: 1)

promover e acompanhar a vigilância da qualidade da água em sua área de competência, em articulação com o nível municipal e os responsáveis pelo controle de qualidade da água; 2) garantir, nas atividades de vigilância da qualidade da água, a implementação de um plano de amostragem pelos municípios, observadas as diretrizes específicas a serem elaboradas pela SVS/Ministério da Saúde; 3) executar ações de vigilância da qualidade da água, de forma complementar, em caráter excepcional, quando constatada, tecnicamente, insuficiência da ação municipal.

A Portaria inova quando delega aos municípios a responsabilidade de atribuir às secretarias Municipais de Saúde a responsabilidade de, dentre outras: 1) exercer a vigilância da qualidade da água em sua área de competência, em articulação com os responsáveis pelo controle de qualidade da água; 2) sistematizar e interpretar os dados gerados pelo responsável pela operação do sistema ou solução alternativa de 
abastecimento de água, assim como, pelos órgãos ambientais e gestores de recursos hídricos, em relação às características da água nos mananciais, sob a perspectiva da vulnerabilidade do abastecimento de água quanto aos riscos à saúde da população ; 3) efetuar, sistemática e permanentemente, avaliação de risco à saúde humana de cada sistema de abastecimento ou solução alternativa, por meio de informações sobre:

a) a ocupação da bacia contribuinte ao manancial e o histórico das características de suas águas;

b) as características físicas dos sistemas, práticas operacionais e de controle da qualidade da água;

c) o histórico da qualidade da água produzida e distribuída; e

d) a associação entre agravos à saúde e situações de vulnerabilidade do sistema;

4) auditar o controle da qualidade da água produzida e distribuída e as práticas operacionais adotadas; 5) garantir à população informações sobre a qualidade da água e riscos à saúde associados; 6) manter registros atualizados sobre as características da água distribuída, sistematizados de forma compreensível à população e disponibilizados para pronto acesso e consulta pública; 7) manter mecanismos para recebimento de queixas referentes às características da água e para a adoção das providências pertinentes; 8) informar ao responsável pelo fornecimento de água para consumo humano sobre anomalias e não conformidades detectadas, exigindo as providências para as correções que se fizerem necessárias;

Estes procedimentos estabelecidos, e anteriormente descritos, dão visibilidade aos problemas encontrados nos mananciais de abastecimento público e nos sistemas de tratamento a eles associados. Pela primeira vez a qualidade do manancial de abastecimento público é colocada como algo importante e objeto de controle. Isto deve favorecer a eleição de mananciais, por parte dos municípios, com maior cobertura florestal, que usualmente garantem água isenta de muitos contaminantes presentes em bacias com ocupação muito diversificada e modificada por ações antrópicas.

A legislação atribui aos serviços de água diversas responsabilidades, entretanto dá-se destaque neste tópico àquelas relativas à qualidade do manancial de abastecimento: 1) responsabiliza os serviços de água pelo controle da qualidade da água de abastecimento; 2) manter avaliação sistemática do sistema de abastecimento 
de água, sob a perspectiva dos riscos à saúde, com base na ocupação da bacia contribuinte ao manancial, no histórico das características de suas águas, nas características físicas do sistema, nas práticas operacionais e na qualidade da água distribuída; 3) promover, em conjunto com os órgãos ambientais e gestores de recursos hídricos, as ações cabíveis para a proteção do manancial de abastecimento e de sua bacia contribuinte, assim como efetuar controle das características das suas águas, notificando imediatamente a autoridade de saúde pública sempre que houver indícios de risco à saúde, ou sempre que amostras coletadas apresentarem resultados em desacordo com os limites ou condições da respectiva classe de enquadramento, conforme definido na legislação específica vigente; 4) fornecer a todos os consumidores, nos termos do Código de Defesa do Consumidor, informações sobre a qualidade da água distribuída, mediante envio de relatório, dentre outros mecanismos, com periodicidade mínima anual e contendo, pelo menos as seguintes informações:

a) descrição dos mananciais de abastecimento, incluindo informações sobre sua proteção, disponibilidade e qualidade da água;

b) estatística descritiva dos valores de parâmetros de qualidade detectados na água, seu significado, origem e efeitos sobre a saúde; e

c) ocorrência de não conformidades com o padrão de potabilidade e as medidas corretivas providenciadas;

5) manter registros atualizados sobre as características da água distribuída, sistematizados de forma compreensível aos consumidores e disponibilizados para pronto acesso e consulta pública.

Há várias discussões que permeiam a aplicabilidade desta legislação. Dentre elas está a falta de estrutura de diversos municípios de aplicá-la, dada a diversidade e a freqüência de parâmetros a serem monitorados. Não são raros os casos em que a estação de captação de águas para abastecimento, sequer monitora a turbidez da água bruta. Entretanto o estado e a federação estão se organizando para suprir estas deficiências.

\subsection{O monitoramento de qualidade e quantidade das águas}

O planejamento e a gestão de recursos hídricos dependem fundamentalmente de informações confiáveis, referentes às demandas e à oferta da 
água, observando-se sua qualidade e quantidade. O monitoramento da quantidade das águas nos corpos hídricos é de fundamental importância para estabelecer uma relação equilibrada entre oferta e demanda, garantindo os usos definidos para cada corpo de água (Braga et al, 1999).

Concentrando o foco deste tópico sobre o monitoramento da qualidade dos sistemas aquáticos, temos de acordo com Braga et al (1999):

"O conceito de monitoramento da qualidade da água é muito mais amplo do que o simples verificar se os padrões legais de qualidade da água estão sendo atendidos ou não. Deve atender à necessidade de se responder o que está sendo alterado e por que estas modificações estão ocorrendo. É importante que se estabeleçam formas de utilização dos dados coletados, permitindo que essas informações sejam úteis ao gestor dos recursos hídricos e à sociedade e que delas resulte um passo a mais no conhecimento dos processos da natureza.".

Segundo Braga et al (1999), um sistema de monitoramento da qualidade da água eficiente é aquele cujos dados disponíveis respondem às perguntas dos seus usuários.

Conforme descrito por CETESB (2000), a Rede de Monitoramento da Qualidade das Águas Interiores do Estado de São Paulo, operada pela CETESB, Agência Ambiental do Estado de São Paulo, foi criada em 1974, em atendimento à Lei Estadual n. ${ }^{\circ}$ 118, promulgada em 29/06/73.

Os principais objetivos dessa rede de monitoramento são:

- avaliar a evolução da qualidade das águas interiores dos rios e reservatórios do Estado;

- propiciar o levantamento das áreas prioritárias para o controle da poluição das águas;

- subsidiar o diagnóstico da qualidade das águas doces utilizadas para o abastecimento público e outros usos;

- dar subsídio técnico para a elaboração dos Relatórios de Situação dos Recursos Hídricos, realizados pelos Comitês de Bacias Hidrográficas;

- identificar trechos de rios onde a qualidade d'água possa estar mais degradada, possibilitando ações preventivas e de controle da CETESB, como a construção 
de ETEs (Estações de Tratamento de Esgotos) pelos municípios ou a adequação de lançamentos industriais.

A CETESB faz uso de 43 parâmetros de qualidade da água (físicos, químicos, hidrobiológicos, microbiológicos e ecotoxicológicos) considerando os mais representativos. São eles:

Parâmetros Físicos - temperatura da água e do ar, série de resíduos, absorbância no ultravioleta, turbidez e coloração da água;

Parâmetros Químicos - pH, oxigênio dissolvido, demanda bioquímica de oxigênio, demanda química de oxigênio, carbono orgânico dissolvido, potencial de formação de trihalometanos, série de nitrogênio, fósforo total, ortofosfato solúvel, condutividade específica, surfactantes, cloreto, fenóis, ferro total, manganês, alumínio, bário, cádmio, chumbo, cobre, cromo total, níquel, mercúrio e zinco.

Parâmetros Microbiológicos - coliforme fecal, Giárdia sp, Cryptosporidium sp, Clostridium perfringens e estreptococos fecais.

Parâmetros Hidrobiológicos - clorofila -a

Parâmetros Ecotoxicológicos - teste de toxicidade crônica a Ceriodaphnia dúbia, teste de Ames para a avaliação de mutagenicidade e sistema Microtox.

Com o intuito de facilitar a interpretação das informações de qualidade de água de forma abrangente e útil, para especialistas ou não, é fundamental a utilização de índices de qualidade. Desta forma, a CETESB, a partir de um estudo realizado em 1970 pela "National Sanitation Foundation" dos Estados Unidos, adaptou e desenvolveu o Índice de Qualidade das Águas - IQA. Este índice vem sendo utilizado para avaliar a qualidade das águas do Estado. No entanto, o IQA apresenta algumas limitações como a possibilidade de superestimar a qualidade da condição real do recurso hídrico (tendo em vista que contempla somente 9 parâmetros) e restringir-se a uma avaliação limitada somente à utilização das mesmas para o abastecimento público.

Com vistas ao aperfeiçoamento da avaliação ambiental, e em cumprimento à Resolução SMA-65, de 13/08/98, a CETESB iniciou, a partir de 1998, o desenvolvimento de dois novos índices de qualidade de água: o Índice de Qualidade de Água Bruta para fins de Abastecimento Público (IAP) e o Índice de Proteção da Vida Aquática (IVA). Como entre os usos mais nobres da água estão o abastecimento 
público e a preservação do equilíbrio das comunidades aquáticas, esses dois índices específicos irão compor, em conjunto com o índice de balneabilidade, o Índice Básico de Qualidade das Águas (IBQA). A aplicação destes índices na rede de monitoramento irá permitir uma abordagem mais completa e fidedigna da qualidade das águas, fornecendo um instrumento importante para o controle e o gerenciamento dos recursos hídricos (CETESB, 2003).

O IQA incorpora nove (9) parâmetros, que são considerados relevantes para a avaliação da qualidade das águas, tendo como determinante principal a utilização das mesmas para abastecimento público.

A criação do IQA baseou-se numa pesquisa de opinião junto a especialistas em qualidade de águas, que indicaram os parâmetros a serem avaliados, o peso relativo dos mesmos e a condição com que se apresenta cada parâmetro, segundo uma escala de valores. Dos 35 parâmetros indicadores de qualidade de água inicialmente propostos, somente nove foram selecionados. Para estes, a critério de cada profissional, foram estabelecidas curvas de variação da qualidade das águas de acordo com o estado ou a condição de cada parâmetro. Estas curvas de variação, sintetizadas em um conjunto de curvas médias para cada parâmetro, bem como seu peso relativo correspondente.

Os parâmetros considerados para o cálculo do IQA são: coliformes fecais, $\mathrm{pH}$, demanda bioquímica de oxigênio, nitrogênio total, fósforo total, temperatura, turbidez, resíduo total e oxigênio dissolvido.

O IQA, numa escala de 0 a 100, é classificado para abastecimento público, segundo a gradação a seguir:

$\begin{array}{cc}\text { Qualidade Ótima } & 79<\mathrm{IQA} \leq 100 \\ \text { Qualidade Boa } & 51<\mathrm{IQA} \leq 79 \\ \text { Qualidade Regular } & 36<\mathrm{IQA} \leq 51 \\ \text { Qualidade Ruim } & 19<\mathrm{IQA} \leq 36 \\ \text { Qualidade Péssima } & \mathrm{IQA}<19\end{array}$

O IAP será o produto da ponderação dos resultados do IQA (Índice de Qualidade de Águas) e do ISTO (Índice de Substâncias Tóxicas e Organolépticas), que é composto pelo grupo de substâncias que afetam a qualidade organoléptica da água, 
bem como de substâncias tóxicas, incluindo metais, além de resultados do teste de Ames (Genotoxicidade) e do Potencial de Formação de Trihalometanos (THMPF). Assim, o índice será composto por três grupos principais de parâmetros.

Os índices que compõe o IAP são então:

IQA: grupo de parâmetros básicos (temperatura da água, $\mathrm{pH}$, oxigênio dissolvido, demanda bioquímica de oxigênio, coliformes termotolerantes, nitrogênio total, fósforo total, resíduo total e turbidez);

ISTO:

a) Parâmetros que indicam a presença de substâncias tóxicas (teste de mutagenicidade, potencial deformação de trihalometanos, cádmio, chumbo, cromo total, mercúrio e níquel) e

b) Grupo de parâmetros que afetam a qualidade organoléptica (fenóis, ferro, manganês, alumínio, cobre e zinco); onde:

ISTO = ST (substâncias tóxicas) $\times$ SO (substâncias organolépticas);

e o IAP será calculado a partir do produto entre o IQA e o ISTO:

\section{IAP = IQA $x$ ISTO}

CETESB \& DE-IB-USP (2000), concluíram que o monitoramento da qualidade da água é, tradicionalmente, realizado através da utilização de parâmetros físicos e químicos da água, em rede de pontos fixos de amostragem, para comparação com padrões de qualidade legalmente estabelecidos para diferentes propósitos. $O$ componente biológico normalmente está presente apenas sob a forma de avaliação da contaminação por bactérias coliformes e a concentração de clorofila-a. Esta abordagem tradicional representa a condição ambiental no momento da coleta do material, necessitando de complementação biológica para uma avaliação em nível ecossistêmico .

Segundo CETESB e DE-IB-USP (2000), o biomonitoramento, definido como o uso sistemático de organismos vivos na determinação da qualidade do 
ambiente aquático, adiciona um componente temporal à avaliação ambiental, representando, com sua presença, a exposição a condições passadas. Este processo utiliza-se de seres vivos presentes nos ecossistemas, em abordagens de escalas espaço-temporais e de níveis de organização variadas, podendo extrapolar o ambiente aquático, incluindo também o seu entorno, incorporando o conceito de bacia hidrográfica (Allan et al.,1997: Allan \& Johnson, 1997).

$\mathrm{Na}$ avaliação da qualidade ambiental, todos os níveis de organização biológica podem ser utilizados, pois a maioria dos efeitos causados por alterações ambientais são ao nível iônico ou molecular, alterando, portanto, fisiologia, comportamento ou capacidade de reprodução.

Há diversas vantagens em se utilizar a biota pra monitoramento: a) exposição prolongada a todas as variações de parâmetros ambientais, fornecendo portanto uma resposta integrada; b) os parâmetros físico-químicos fornecem uma avaliação instantânea e a biota apresenta: diferentes sensibilidades e taxas de recuperação(dependendo dos ciclos de vida), e concentração e armazenamento de substâncias em seus tecidos(muitas vezes sustâncias não detectadas no ambiente podem ser desta forma detectadas) (Navas-Pereira, 2001).

A seleção de espécies indicadoras, segundo Navas-Pereira (2001), de modo geral, baseia-se em: importância econômica como recurso ou nocividade; dados sobre ecologia e fisiologia já conhecidos; distribuição cosmopolita; capacidade de acumulação de substâncias poluentes; facilidade de amostragem; pouca variabilidade genética; facilidade de cultivo; abundância numérica.

As duas categorias de variáveis biológicas de possível utilização são fitoplâncton de água doce e bentos de água doce, conforme definições de NavasPereira (2001).

Fitoplâncton é o termo utilizado para se referir à comunidade de vegetais microscópicos que vivem em corpos de água e que são constituídos principalmente por algas: cianofíceas, clorofíceas, diatomáceas, euglenofíceas, crisofíceas e xantofíceas.

Algas são organismos vegetais clorofilados e constituem parte da comunidade de um ecossistema aquático, podendo constituir a base da cadeia alimentar desse ambiente. Utilizando a energia solar, transformam nutrientes minerais em matéria orgânica, fenômeno conhecido como fotossíntese.

Em geral, águas limpas e pobres em nutrientes apresentam uma 
comunidade fitoplanctônica pouco abundante, mas com certa diversidade, enquanto que águas ricas em material orgânico apresentam em geral grande número de organismos pertencentes a poucas espécies.

Mananciais poluídos apresentam grande disponibilidade de nutrientes e deste fato decorre a possibilidade da formação de ambientes eutrofizados e ecologicamente desequilibrados. A ocorrência destes ambientes eutrofizados concorre para a proliferação de algas diversas, as quais podem apresentar uma série de problemas tais como flutuações de oxigênio dissolvido, cor, odor, sabor e toxicidade da água. Esses efeitos são indesejáveis em mananciais de abastecimento público e recreação, pois dificultam e oneram o processo de tratamento da água.

Os organismos bênticos ou bentônicos, no ambiente de água doce, vivem sobre o fundo ou enterrados nele, aderidos ou livres, mas apresentando em geral pouca mobilidade. Estas formas de vida incluem bactérias, algas, plantas aquáticas superiores, micro fauna e macro fauna. Os componentes da macro fauna vivem pelo menos parte de suas vidas sobre substratos de um corpo d'água. Esta comunidade é em geral composta por nemátodos, anelídeos, moluscos, crustáceos e larvas de insetos. Um corpo de água de boa qualidade geralmente suporta uma fauna bêntica diversificada, sem superabundância de qualquer grupo. A macro fauna bêntica é composta por organismos onívoros, carnívoros ou herbívoros e, em ecossistema balanceado, os três tipos poderão estar presentes. Os macroinvertebrados são membros importantes da cadeia alimentar e suas condições se refletem no estado de outros organismos de maior tamanho, tais como peixes. Ainda conforme Navas-Pereira (2001), a comunidade de macroinvertebrados em um ecossistema aquático é muito sensível a perturbações resultantes da introdução de contaminantes. O fenômeno de acumulação biológica pode ser detectado pela análise química de organismos selecionados da fauna de macroinvertebrados.

Navas-Pereira (2001) afirma que a poluição orgânica pode restringir a variedade da macro fauna bêntica e favorecer o desenvolvimento de grande número de organismos que toleram condições de poluição, de natureza física e química. O conhecimento de bentos tem várias aplicações, dentre elas estão: 1) programas de monitoramento e levantamento ecológico de mananciais; 2) fornecimento de subsídios para a avaliação da qualidade da água de mananciais; 3) estudos sobre a natureza, extensão e efeitos de poluição por esgoto doméstico ou industrial em corpos d'água. 
O monitoramento de algas em captações na extensão da Bacia do rio Piracicaba, Estado de São Paulo, tem sido feito rotineiramente, diante do grau de comprometimento dos rios, com a alta carga de esgotos domésticos ali lançados e os freqüentes episódios de floração de algas, associados a paralisações nas captações de água para o abastecimento público. A CETESB, Agência Ambiental do Estado de São Paulo, realiza este monitoramento, porém alguns municípios têm se capacitado para fazê-lo, dada a freqüência de ocorrência de episódios de floração.

A extensão do monitoramento biológico no Estado de São Paulo para outras categorias de organismos, sua popularização através de capacitação da população, e o aumento de pontos monitorados ao longo de bacias de abastecimento público podem ser, juntos, um importante instrumento de envolvimento da população com a saúde da bacia hidrográfica e uma ferramenta de controle da qualidade de suas águas.

\subsection{A bacia hidrográfica como unidade de gestão, estratégias e experiências de manejo}

A bacia hidrográfica é um sistema geomorfologicamente aberto, que recebe energia através de agentes climáticos e perde através do deflúvio. A bacia hidrográfica como sistema aberto pode ser descrita em termos de variáveis interdependentes, que oscilam em torno de um padrão e desta forma, uma bacia mesmo quando não perturbada por ações antrópicas, encontra-se em equilíbrio dinâmico (Lima, 1999).

O uso da bacia hidrográfica como unidade de intervenção é uma das alternativas de estabelecimento do sistema a ser gerenciado. Ela apresenta algumas vantagens e desvantagens. A vantagem é que a rede de drenagem de uma bacia consiste num dos caminhos preferenciais de boa parte das relações causa-efeito, particularmente aquelas que envolvem o meio hídrico. As desvantagens são que nem sempre os limites municipais e estaduais respeitam os divisores da bacia e, conseqüentemente, a dimensão espacial de algumas relações de causa-efeito de caráter econômico e político. Além disso, em certas situações, a delimitação completa de uma bacia hidrográfica poderá estabelecer uma unidade de intervenção 
demasiadamente grande para a negociação social. Nesses casos, alguns esquemas de subdivisão de grandes bacias deverão ser adotados, em conjunto com uma necessária articulação entre as partes (Lanna, 1995).

A escala de trabalho está intrinsecamente relacionada ao objetivo do estudo e à paisagem avaliada. Uma paisagem pode ser composta por alguns centímetros, como por quilômetros de distância, dependendo do objetivo ou do ponto de vista que essa é avaliada. Numa escala macro, pode-se ter como exemplos de paisagens, um país, uma região ou um bioma. Nessa situação, tem-se como exemplos de paisagens, para a escala meso a bacia hidrógrafica e para escala micro a microbacia. Numa outra situação ilustrativa podemos considerar, como exemplos de paisagem, a bacia hidrográfica na escala macro, a microbacia na escala meso e a propriedade rural na escala micro de trabalho.

Numa escala de bacia hidrográfica ou regional (escala macro), um indicador de sustentabilidade dos recursos hídricos, em função do manejo ou uso dos recursos naturais, ter-se-ia, por exemplo, a própria disponibilidade natural de água, a qual pode ser quantificada pelo balanço hídrico (Lima, 1999).

Lima (1999) afirma que na escala de unidade de manejo da propriedade rural (escala micro), a compactação do solo, a destruição da matéria orgânica do solo, a destruição da microbiologia do solo, para citar algumas, não concorrem para a manutenção dos recursos hídricos, uma vez que degradam o mais importante fator hidrológico desta manutenção, que é o processo de infiltração de água no solo e que, para esses casos, pode ser considerado como um indicador da sustentabilidade dos recursos hídricos.

$\mathrm{Na}$ escala da microbacia hidrográfica (escala meso), pode-se identificar outros indicadores de sustentabilidade dos recursos hídricos, tais como o traçado das estradas e as condições da zona ripária (Lima, 2000).

Em 1992, na Conferência das Nações Unidas sobre o meio ambiente e desenvolvimento, foi sugerida a adoção da bacia hidrográfica como unidade de gestão, conforme descrito no capítulo 18 da Agenda 21:

"O manejo integrado dos recursos hídricos, inclusive a integração de aspectos relacionados à terra e à água, deve ser feito ao nível de bacia ou sub-bacia de captação. Quatro 
objetivos principais devem ser perseguidos: promover uma abordagem dinâmica interativa, iterativa e multisetorial do manejo dos recursos hídricos, incluindo a identificação e proteção de fontes potenciais de abastecimento de água doce que abarquem considerações tecnológicas, sócio-econômicas, ambientais e sanitárias."

A origem do manejo de microbacias pode ser estabelecida, segundo Lanna (1995), em duas iniciativas paralelas e independentes: a reabilitação dos Alpes, a partir do último quarto do século XIX, e o movimento conservacionista americano, iniciado em 1930. Na primeira iniciativa, o foco se dirigiu ao desenvolvimento e aplicação de técnicas de recuperação de terras e correção de cursos d'água torrenciais. Na segunda, a atenção foi orientada para o manejo da vegetação e conservação do solo e dos recursos hídricos. A característica comum às duas iniciativas é que elas foram concebidas para bacias com pouca ou nenhuma atividade antrópica.

As experiências de manejo dos países em desenvolvimento ocorreram em bacias povoadas. A política econômica vigente promoveu a concentração de renda, levando à marginalização parte significativa da sociedade. Esse segmento marginalizado ocupou periferias dos grandes centros urbanos ou áreas impróprias para a produção agrícola, caracterizadas por alta declividade, baixa fertilidade e carência geral de recursos ambientais com valor econômico. Para sobreviver, esse segmento adotou práticas ambientalmente inadequadas, gerando impactos que se propagavam através dos cursos d'água, afetando os segmentos economicamente mais favorecidos, situados a jusante das bacias. Somente então, nesses países, o problema ganhou dimensão (Lanna, 1995).

As experiências sobre estratégias e gerenciamento de bacias hidrográficas descritas na literatura são diversas, muitas delas com o objetivo de preservar mananciais de abastecimento público.

As bacias hidrográficas de Catskill, Delaware e Croton juntas fornecem $4.921 .035 \mathrm{~m}^{3} / \mathrm{dia}, 57 \mathrm{~m}^{3} / \mathrm{s}$ de água para abastecer nove milhões de pessoas residentes na cidade de Nova York e na área metropolitana. Há décadas atrás, as autoridades, preocupadas com a necessidade de incrementar o tratamento de água da cidade, conforme exigência da Agência Ambiental Americana - EPA, chegaram à conclusão de 
que seria mais barato purificar as águas de abastecimento, investindo no manejo das bacias hidrográficas já florestadas, do que construir nova estação de tratamento de água para a cidade (WWF \& IUCN, 2003). As águas provenientes das bacias de Catskill, Delaware e Croton, hstoricamente, fornecia água de boa qualidade, sem necessitar de coagulação ou filtração, sendo utilizada apenas cloração. Nos últimos anos, entretanto, as autoridades e especialistas identificaram a necessidade de se adicionar unidades de filtração às unidades já existentes. A bacia de Cróton é a mais fortemente desenvolvida e é responsável por cerca de $10 \%$ do volume da água de abastecimento fornecida à Nova York; as águas das bacias hidrográficas de Delaware/Catskill são responsáveis pelos outros $90 \%$ do volume de abastecimento. Setenta por cento das terras das bacias Catskill/Delaware pertencem a proprietários privados. A população destas duas bacias varia entre 50.000 e 200.000 habitantes, dependendo da estação do ano. Há receio de que a interferência antrópica degrade a qualidade das águas.(National Research Council et al., 2000).

Em 21 de janeiro de 1997 foi assinado o mais gigantesco acordo relacionado ao gerenciamento dos recursos hídricos na história americana. O acordo, chamado de New York City Watershed Memorandum of Agreement (MOA), oferece um instrumento legal de proteção das águas de abastecimento para nove milhões de pessoas. O acordo é resultado de anos de negociação entre os interesses dos usuários das águas das cabeceiras dos rios, com os interesses dos usuários das partes mais baixas dos rios. O acordo conduz a cidade de Nova York a um programa de gerenciamento de recursos hídricos de longo prazo, que combina aquisição de terras, novas regras e regulamentos para bacias hidrográficas, assistência financeira para as comunidades das bacias, a fim de promover qualidade ambiental e seu desenvolvimento econômico regional. O acordo satisfaz às exigências da Agência de Proteção Ambiental americana, EPA, que, a partir desse acordo, retardaram a exigência de implantação de unidades adicionais de filtração ao tratamento das águas dos mananciais de abastecimento de Nova York. O custo do programa está estimado entre US\$ 1 a US\$ 1,5 bilhões, ao longo de dez anos; a construção da planta de tratamento complementar está estimada em US\$ 6-8 bilhões, com custo adicional anual de operação de US\$ 300-500 milhões. Os habitantes de Nova York concordaram em ter seus valores de conta elevados a fim de financiar a criação de um fundo para a manutenção do programa. (National Research Council et al., 2000). 
As florestas ocupam 75 da área das três bacias, mas os proprietários das terras são diversos. A cidade de Nova York, por exemplo, possui menos de $10 \%$ dessas terras. A implantação do programa pelos gerenciadores implicou no trabalho com uma diversidade de proprietários, regimes de gerenciamento e necessidade de diferentes tomadores de decisão (stakeholders), resultando em diferentes modelos de gerenciamento. Várias formas de compensação foram introduzidas, tais como: US\$40 milhões para donos de pastagens e florestas, que adotarem as melhores práticas de manejo; licenças adicionais para companhias de produção de madeira que aumentarem suas práticas de gerenciamento de florestas e redução de impostos para proprietários de propriedades florestadas que mantenham o compromisso de atualizar planos de manejo florestais a cada dez anos. A cidade está ainda adquirindo terras mais sensíveis em termos hidrológicos e contatando agricultores para que eles excluam terras ambientalmente mais sensíveis de suas terras produtivas (National Research Council et al., 2000).

O Acordo prevê o envolvimento de diversas instituições governamentais e estabelece uma diversidade de comitês e programas, associados a recursos financeiros, como por exemplo: programa de máxima carga diária, programa de aumento do monitoramento das águas, programa de aquisição de terras.

$\mathrm{Na}$ bacia do rio Piracicaba, a bacia do rio Corumbataí abrangendo uma área de 170.775,6 ha, têm uma população aproximada de 500.000 habitantes, incluindo-se o município de Piracicaba e representa hoje a principal fonte de abastecimento de água para Piracicaba e mais sete municípios que a compõe. Sua cobertura florestal encontra-se degradada e reduzida, em função de um processo desordenado de uso e ocupação do solo, o que acarreta sérios prejuízos para a conservação dos mananciais de abastecimento de água, para a conservação da biodiversidade e para o desenvolvimento sustentável regional (IPEF, 2001).

O Serviço Municipal de Água e Esgoto de Piracicaba (SEMAE), diante da importância estratégica dessa bacia, contratou junto ao Instituto de Pesquisas e Estudos Florestais (IPEF) a elaboração de um Plano Diretor para a Conservação dos Recursos Hídricos por meio da Recuperação e Conservação da Cobertura Florestal da Bacia do Rio Corumbataí.

Um dos principais produtos gerados, que compõe esse plano diretor, foi o mapa de áreas prioritárias para a conservação e preservação florestal. Esse mapa 
foi produzido tendo por base a abordagem multi-critérios/único objetivo, na tomada de decisão em ambiente SIG ( Sistema de Informações Geográficas). Os critérios utilizados para criar o mapa de áreas prioritárias para a conservação e preservação florestal e seus respectivos pesos podem ser observados no Quadro 2.

As áreas consideradas de muito alta e alta prioridade para a conservação e preservação florestal correspondem, respectivamente, a 6,35\% e $12,58 \%$ da área total da bacia.

\begin{tabular}{|c|c|}
\hline Critérios & Pesos( $\%)$ \\
\hline Proximidade às nascentes & 45,64 \\
\hline Proximidade à cobertura florestal & 22,92 \\
\hline Adequação do uso e cobertura do solo & 9,16 \\
\hline Erodibilidade de solo & 9,16 \\
\hline Erosividade da chuva & 9,16 \\
\hline
\end{tabular}

Quadro 2 - Critérios e pesos para a definição das áreas prioritárias para a conservação e recuperação florestal na Bacia do Rio Corumbataí Fonte: IPEF \& SEMAE (2001)

A realização desse estudo é inédita no Brasil e trata-se de iniciativa que deve ser valorizada pelo poder público regional e estadual. Algumas das conclusões mais importantes do estudo de IPEF \& SEMAE (2001) foram:

A bacia hidrográfica do rio Corumbataí vem apresentando uma tendência de diminuição da vazão média, o que significa que a demanda de água da bacia tem crescido nos últimos 15 anos. A análise das vazões máximas e mínimas e a adequação do uso do solo às suas características ecológicas indica que o uso do solo e/ou o manejo do solo na bacia são inadequados, resultando em aumento de turbidez na água. Conseqüentemente, a captação do município de Piracicaba no rio Corumbataí pode ficar comprometida ao longo do tempo.

A recuperação e conservação da cobertura florestal podem colaborar para resolver, em parte, os problemas de regime e de qualidade da água da bacia do rio Corumbataí. Foram identificadas sub-bacias e microbacias prioritárias para os trabalhos de recuperação e conservação florestal.

O mapeamento da cobertura florestal atual na bacia mostra que ela conta com 12,4 \% de cobertura florestal nativa. Devem ser desenvolvidas ações 
dirigidas para a recuperação da cobertura florestal em cerca de $15 \%$ da bacia, onde o uso atual do solo não é apropriado, em função das limitações pedológicas existentes.

Devem ser recuperados cerca de 9.320 ha de florestas, apenas considerando-se as áreas de preservação permanente. Mantido o atual nível de investimento, resultante da contribuição de $\mathrm{R} \$ 0,01 / \mathrm{m}^{3}$ de água captada pelos municípios de Piracicaba e Santa Gertrudes, este plantio demoraria cerca de 118 anos, excluídas eventuais perdas de cobertura florestal que venham a ocorrer nesse período.

Devem ser buscados mecanismos complementares de financiamento das atividades florestais, incluindo seqüestro de carbono e políticas tributárias municipais e estaduais.

Segundo Randhir et al. (2001), o gerenciamento da qualidade da água através de unidades de microbacias hidrográficas é importante para a proteção de mananciais de abastecimento. Confrontando os custos de tratamento de água para abastecimento público com o custo necessário para o desenvolvimento de soluções entre usuários da bacia, reforça a necessidade de desenvolver esta última solução. O trabalho defende portanto a aplicação de investimentos na bacia hidrográfica, visando a conservação dos recursos hídricos, através de medidas de proteção do solo por exemplo, com o desenvolvimento de modelo para priorizar áreas a serem protegidas ou recuperadas.

Os autores afirmam que, durante as últimas décadas, a água, este recurso vital, tem se deteriorado rapidamente, como resultado das atividades antrópicas. O US Clean Water Act de 1972 nos Estados Unidos foi efetivo na redução de poluição das águas, mas, a despeito deste progresso, 40\% dos cursos de água estão impróprios para a pesca e recreação.

Soluções para a poluição causada por fontes difusas incluem medidas preventivas e de recuperação, usando medidas estruturais e não estruturais. Considerando-se uma comparação entre os custos relativos ao tratamento da água e aquele referente à recuperação de áreas e medidas preventivas aplicadas na unidade da bacia hidrográfica, o segundo será mais vantajoso em termos econômicos. Um fator crítico nas soluções que envolvem o manejo de microbacias hidrográficas está na capacidade dos organismos gestores de priorizarem as soluções que envolvam uso do solo e centrar programas e políticas para áreas que tragam maiores benefícios (Randhir et al., 2001). 
Randhir et al. (2001) afirmam que as medidas estruturais e não estruturais de recuperação de áreas em microbacias hidrográficas dependem de tomadores de decisão. Para concretizar estas soluções, a priorização de recuperação de sítios é importante. O trabalho desenvolve um recurso que visa priorizar a recuperação de sítios em uma bacia hidrográfica, visando a manutenção da qualidade da água. Entretanto, o modelo pode também ser utilizado para identificar o custo efetivo das medidas de proteção e recuperação na bacia hidrográfica em estudo.

Os objetivos específicos do trabalho desenvolvido por Randhir et al. (2001) foram:

- desenvolver um modelo para priorização de terras com intuito de proteger a qualidade das águas em microbacias hidrográficas;

- desenvolver metodologia para avaliar a distribuição do tempo de trânsito relativo ao longo da bacia;

- identificar sítios na bacia hidrográfica do rio Ware que são mais sensíveis à degradação da qualidade das águas, visando a implantação de um programa de aquisição de terras.

O estudo focou seu desenvolvimento sobre a bacia hidrográfica do rio Ware, uma das três microbacias responsáveis pelo abastecimento público de Boston. $\mathrm{O}$ Metropolitan District Commision (MDC) of Massachussets Commonwealth é a agência responsável pelo gerenciamento dessas três Microbacias. A Agência está envolvida num programa de aquisição de terras a fim de protegê-las da urbanização, recuperar e manter cobertura florestal estável. As microbacias hidrográficas florestadas têm demonstrado que produzem água de qualidade superior, quando comparado este uso da terra com outros (Omernick, 1976 citado por Randhir et al., 2001 ).

O estudo gerou dois mapas da bacia Ware River como resultado da aplicação da metodologia desenvolvida, sendo eles: mapa de distribuição do tempo de trânsito relativo e mapa de distribuição da priorização de áreas.

Preocupados com a implementação de políticas para saúde e meio ambiente no Canadá e o papel do gerenciamento de bacias hidrográficas na manutenção da qualidade de água de mananciais de abastecimento público, Davies \& Mazumder (2003) afirmam que todos os níveis de governo (municipal, estadual e federal) são responsáveis por implementar políticas para garantir a proteção dos 
recursos hídricos e de fornecer instrumentos para alcançar os objetivos dessas políticas. O gerenciamento dos recursos hídricos deve ser baseado no conhecimento científico sobre os riscos sobre a saúde e o meio ambiente, associados a custos e aceitação social desses riscos e custos.

Os desafios para se atingir a sustentabilidade das águas de abastecimento incluem uma lacuna de reconhecimento do papel de forte sistema de gerenciamento de bacias hidrográficas e de descontinuidade entre aqueles que elaboram as políticas, os instrumentos para aplicar as políticas, os gerenciadores e os cientistas.

O estudo de Davies \& Mazumder (2003) teve por objetivo demonstrar a necessidade de implantação de políticas fortes para dirigir o gerenciamento de mananciais de água para abastecimento e o papel crítico da integração das tradicionais áreas da política, gerenciamento, saúde e meio ambiente. Examinaram-se as implicações sobre saúde e meio ambiente das políticas para mananciais de abastecimento público. A qualidade da água foi definida pela perspectiva da saúde humana e as maiores doenças e riscos ambientais associados à saúde humana foram relacionados. Os autores buscaram a filosofia, que muitos gerenciadores atualmente incorporam, de atuar sobre a perspectiva do melhor tratamento de água para abastecimento público e do melhor gerenciamento sobre o manancial de abastecimento público.

Foram listados os problemas mais sérios e atuais relacionados à saúde e à qualidade da água, tais como: organismos patogênicos entéricos, patógenos resistentes à desinfecção, sub-produtos da desinfecção, contaminação química, cianobactérias.

Davies \& Mazumder (2003) apontam as políticas e seus instrumentos para o Canadá, apresentando um quadro interessante de comparação dos limites praticados pelo Canadá, USA e pela Organização Mundial da Saúde para os diferentes contaminantes para qualidade das águas, a presença de legislação e controle, proteção e várias ações simultâneas executadas de forma concatenada.

A proteção da água para consumo humano deve focar a qualidade do manancial de abastecimento, ao invés de sofisticar o tratamento. O tratamento apenas está sujeito a falhas, mas é fundamental como parte de uma abordagem de múltiplas ações. A proteção de fontes de água superficiais pode reduzir o número de patógenos 
e matéria orgânica que adentram os sistemas de tratamento de água, reduzindo os riscos à saúde da população (Davies \& Mazumder, 2003).

Os autores ressaltam que todos os países precisam considerar as implicações de curto e longo prazo decorrentes do gerenciamento de mananciais. A prevenção da poluição das águas parece ser a mais sensata e prudente direção para o gerenciamento de recursos hídricos. A água é essencial para a sustentabilidade do meio e, assim, as políticas devem ser somadas ao manejo e uso da água, de forma sustentável.

A bacia hidrográfica como unidade de manejo e a proteção de florestas para águas de abastecimento público traz também diversas implicações sociais. Conforme pesquisa realizada por WWF \& IUCN (2003), o gerenciamento de bacias hidrográficas oferece benefícios às pessoas que vivem ao longo da bacia, incluindo milhões de habitantes que dependem da água de abastecimento proveniente dessas bacias hidrográficas florestadas. O estabelecimento de florestas protegidas ou recuperadas pode ser bom para os recursos hídricos, mas pode ter muitas implicações sobre a vida das pessoas que vivem nessas áreas e têm suas próprias idéias sobre como as áreas deveriam ou poderiam ser utilizadas.

As opções sobre o uso da terra, quando observado o interesse comum, usualmente serão impostas pelo poder gestor ou negociadas com os donos da terra, ou uma mistura de ambas as possibilidades. Em geral, o gerenciamento de recursos naturais está tendendo a distanciar-se de soluções impostas, pois elas geralmente resultam em problemas e caminhar em direção a acordos negociados e com administração de colaboradores é mais plausível.

Em decorrência dos interesses urbanos serem politicamente mais fortes do que os interesses da zona rural, a proteção de bacias hidrográficas tem, freqüentemente, ignorado os direitos da população rural, com impactos negativos para milhões de pessoas, incluindo:

- Transferência de propriedade ou de direito de uso da terra de moradores da localidade;

- Direitos negados ao acesso à terra pública ou comunitária, floresta ou água;

- Oferecimento de pagamentos pelos serviços da água que encoragem mais atores poderosos a adquirirem terras; 
- Estabelecimento de florestas plantadas em terras comunitárias valiosas para pastagem e outros usos;

- Forçando o reassentamento de pessoas;

- Forçando fazendeiros a executar obras de conservação de alto custo;

- Danificando ou negando acesso a locais de importância cultural ou religiosa;

- Reduzindo empregos em fazendas fechadas ou em outras atividades;

- Desviando água para usuários urbanos.

Esses problemas levaram a novas formas de lidar com a questão, buscando trabalhar com pessoas da localidade, como agentes da bacia hidrográfica. Isto mostra reconhecimento dos seus direitos, sua capacidade de gerenciamento, encoraja negociações e fornece suporte técnico e financeiro para que as comunidades invistam no manejo das terras. 


\section{MATERIAL}

Para o alcance dos objetivos propostos, os materiais de estudo compreendem:

a) As sete Estações de Tratamento de Águas (ETAs), suas captações e bacias hidrográficas de origem da água de abastecimento. Fez-se necessária assim a organização das informações sobre cada um desses sistemas de abastecimento público.

b) As bacias hidrográficas dos rios Piracicaba e Corumbataí, incluindo a análise de suas características físicas, demográficas, econômicas, de planejamento municipal e de qualidade das águas do corpo d'água principal.

\subsection{Custo do tratamento de água $x$ cobertura florestal da bacia}

\subsubsection{As Estações de Tratamento de Água (ETAs) e respectivas captações.}

As estações de tratamento de água foram utilizadas como objeto de estudo, pois refletem a qualidade da saúde da bacia hidrográfica do manancial de abastecimento público. As operações de tratamento a que são submetidas as águas brutas utilizadas para o abastecimento público são mais sofisticadas, na medida em que a qualidade do manancial está mais comprometida; o volume e a diversidade de produtos químicos adicionados às águas brutas também estão diretamente relacionados com a qualidade da água que adentra a estação.

Neste segmento serão descritas as estações de tratamento de água para abastecimento público situadas em diversas bacias hidrográficas, seis na bacia hidrográfica do rio Piracicaba e uma na bacia do Alto Cotia.

A Figura 3 localiza as captações e as estações de tratamento que 
tiveram seus dados operacionais analisados na UGRHI PCJ-05.

Nos itens subseqüentes serão descritas as unidades de tratamento e os dados operacionais obtidos junto às operadoras do recurso.

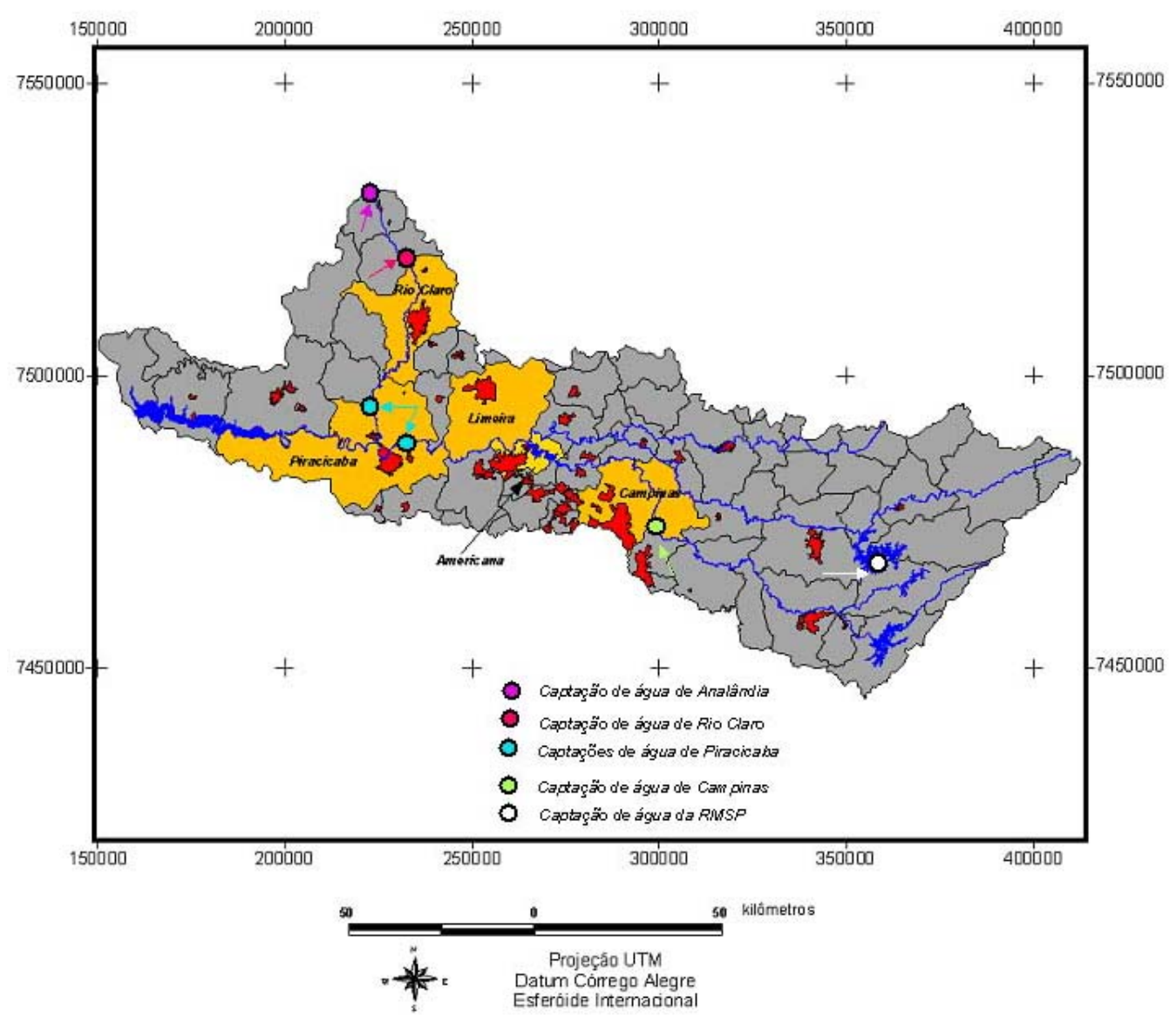

Figura 3 -Localização das captações e ETAs na bacia do rio Piracicaba.

Fonte:PIRACENA (2004) 


\subsubsection{Estação de Tratamento do município de Analândia e seu manancial de captação}

A água para abastecimento público do município de Analândia, situado nas cabeceiras do rio Corumbataí, é captada no córrego do Retiro, a cerca de três quilômetros da sua nascente.

A Estação de Tratamento de Água do município de Analândia situa-se nas proximidades da captação e não é do tipo convencional. A estação é composta pelas seguintes unidades: câmara de aguapés com peixes, leito de solos filtrantes e cloração final.

O município consome energia com a captação das águas para abastecimento público. As águas seguem por gravidade para a ETA.

Os dados principais da estação de tratamento e de características do manancial de captação estão descritos no Quadro 3.

\begin{tabular}{|c|c|}
\hline Nome & Estação de Tratamento de Água de Analândia \\
\hline Município & Analândia \\
\hline Manancial de Captação & córrego Retiro, pertencente à bacia do rio Corumbataí \\
\hline Área da bacia & Desconhecida \\
\hline $\begin{array}{r}\text { Percentual de Cobertura florestal } \\
\text { na bacia }\end{array}$ & $17,68 \%$ \\
\hline Tipo de processo de tratamento & não convencional \\
\hline Etapas de Tratamento & $\begin{array}{l}\text { câmara de aguapé com peixes, filtração em leito de solos } \\
\text { filtrantes } \\
\text { com plantação de arroz e desinfecção final com cloro } \\
\text { líquido }\end{array}$ \\
\hline Vazão de água produzida & $15 \mathrm{l} / \mathrm{s} ; 80 \mathrm{~m}^{3} / \mathrm{dia}$, captando dia sim e dia não \\
\hline População abastecida & 3480 habitantes \\
\hline Produtos químicos utilizados & cloro \\
\hline $\begin{array}{r}\text { Turbidez média da água bruta } \\
\text { (abril a outubro) }\end{array}$ & não há dado disponível. \\
\hline $\begin{array}{r}\text { Turbidez média da água bruta } \\
\text { (novembro a março) }\end{array}$ & não há dado disponível \\
\hline Volume de Lodo gerado & não há geração de lodo na ETA \\
\hline Base de dados & ano 2003 \\
\hline
\end{tabular}

Quadro 3 - Estação de Tratamento de Água de Analândia e seu manancial de captação 
A Figura 4 refere-se ao local da captação do município de Analândia no córrego do Retiro, podendo-se observar a falta de proteção do seu entorno, o porte da estação e a simplicidade de suas instalações..

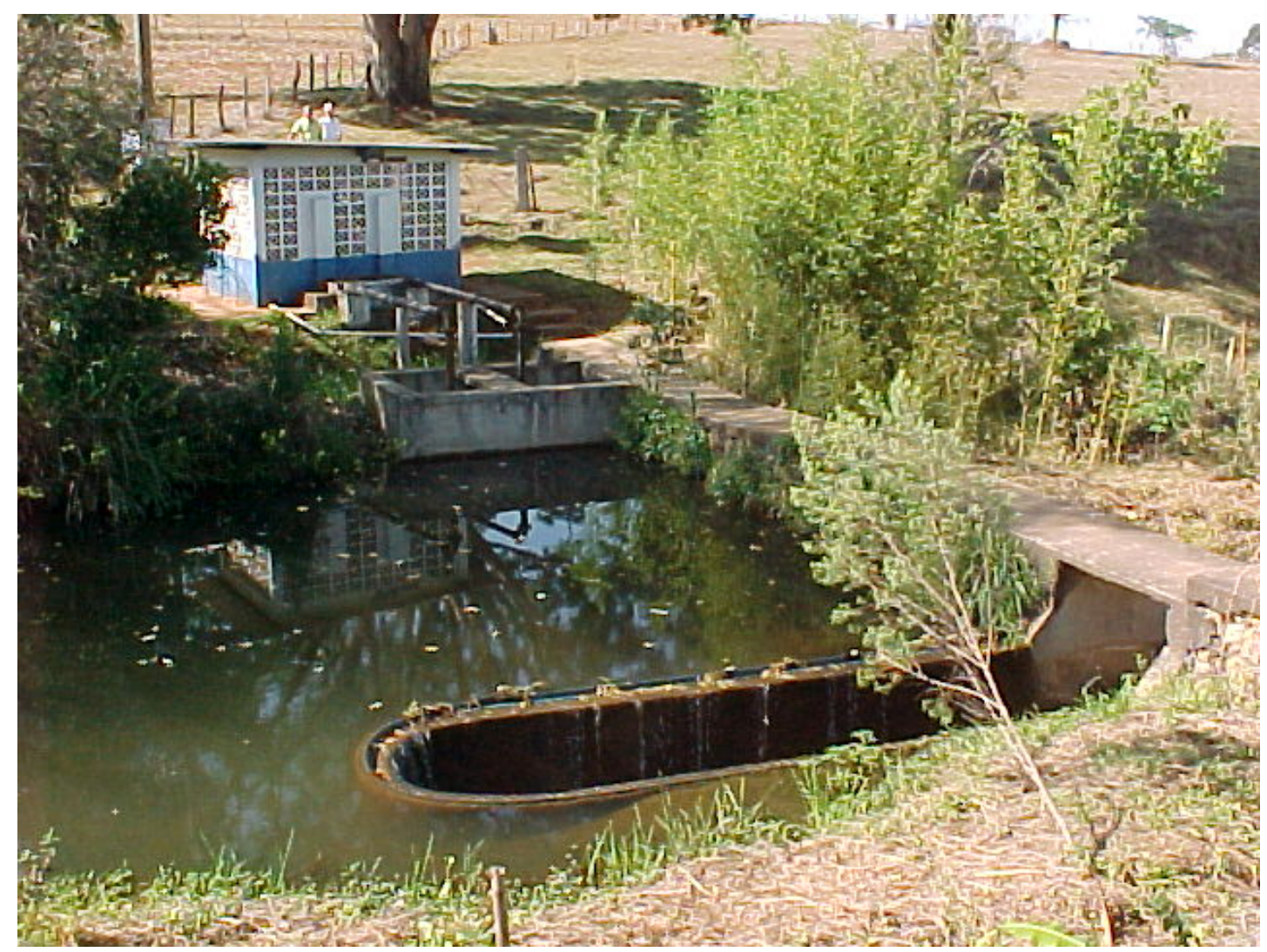

Figura 4 - Captação de Analândia no córrego do Retiro, nas cabeceiras do rio Corumbataí

\subsubsection{Estação de Tratamento do município de Rio Claro e seu manancial de captação}

A água para abastecimento público do município de Rio Claro possui dois mananciais, o rio Corumbataí, a montante do município e o ribeirão Claro, afluente do rio Corumbataí, que após a passagem pelo município, perde qualidade para abastecimento público.

O município possui duas estações de tratamento de água: a ETA I situase no centro da cidade e a captação correspondente situa-se às margens do ribeirão 
Claro, afluente do rio Corumbataí; a Estação de Tratamento de água ETA II situa-se à estrada Rio Claro-Ajapi, $n^{\circ}$ 7453, junto à captação correspondente, localizada às margens do rio Corumbataí.

As ETAs I e II são do tipo convencional. As estações são compostas pelas seguintes operações: mistura rápida, coagulação e floculação, sedimentação, filtração, desinfecção final, fluoretação e correção final de $\mathrm{pH}$.

A ETA II foi projetada em 1980, com inauguração em 1987 e capacidade para tratar $500 \mathrm{l} / \mathrm{s}$. Apenas esta estação será objeto de estudo, por tratar as águas do rio Corumbataí.

Os dados principais da estação de tratamento e de características do manancial de captação estão descritos no Quadro 4.

\begin{tabular}{|c|c|}
\hline Nome & Estação de Tratamento de Água ETA II \\
\hline Município & - \\
\hline Manancial de Captação & rio Corumbataí \\
\hline Área da bacia & $611,18 \mathrm{Km}^{2}$ * \\
\hline $\begin{array}{r}\text { Percentual de Cobertura florestal } \\
\text { na bacia }\end{array}$ & $12,26 \%$ * \\
\hline Tipo de processo de tratamento & convencional \\
\hline Etapas de Tratamento & $\begin{array}{l}\text { pré-cloração, adição de coagulantes, mistura rápida, } \\
\text { coagulação-floculação, decantação convencional, filtração; } \\
\text { desinfecção final, controle de pH e fluoretação. }\end{array}$ \\
\hline Vazão de água produzida & $400 \mathrm{l} / \mathrm{s} ; 37.562 \mathrm{~m}^{3} / \mathrm{dia}$ \\
\hline População abastecida & 104.715 habitantes (60 \% da população) \\
\hline Produtos químicos utilizados & cloro, cal, cloreto férrico, ácido fluorsilícico \\
\hline $\begin{array}{r}\text { Turbidez média da água bruta } \\
\text { (abril a outubro) }\end{array}$ & 36,60 NTU \\
\hline $\begin{array}{r}\text { Turbidez média da água bruta } \\
\text { (novembro a março) }\end{array}$ & $123,00 \mathrm{NTU}$ \\
\hline Base de dados & ano 2002 \\
\hline
\end{tabular}

Quadro 4. Estação de Tratamento de Água ETA II de Rio Claro e seu manancial de captação

* Fonte: IPEF \& SEMAE (2001)

\subsubsection{Estação de Tratamento de Água Capim Fino do município de Piracicaba e seu manancial de captação}

A Estação de Tratamento de Água Capim Fino - ETA 3 localiza-se no Bairro Guamium, saída 27 da Rodovia 127 (Piracicaba-Rio Claro), em Piracicaba - SP e foi inaugurada em 1982. 
A água é captada na estação elevatória de água bruta (Captação 3), localizada às margens do Rio Corumbataí, onde através de quatro adutoras percorre $5,4 \mathrm{Km}$ até chegar à ETA 3.

Na entrada da ETA 3, essa água é recebida em uma câmara de tranqüilização onde ocorre a pré-cloração e aplicação de cal hidratada, seguindo então para a calha Parshall onde é feita a medição da vazão e aplicado cloreto férrico e, às vezes, carvão ativado.Após essa etapa, a água é encaminhada para as câmaras de floculação, onde se inicia o processo de separação das impurezas da água através da formação dos flocos, seguindo então para os tanques de decantação, responsáveis pela sedimentação dos flocos. Após essa etapa a água é conduzida para os filtros, compostos de carvão antracito (mineral) e areia, que tem a função de dar um polimento final à água. Após a fase de filtração, a água já está totalmente límpida e segue para a caixa de nível constante, onde é feita a pós-cloração, fluoretação (utilizada para prevenção de cáries dentárias) e correção final de pH (para eliminar a acidez da água e proteger as tubulações de distribuição), indo para os reservatórios e entregue aos consumidores.

A Figura 5 apresenta uma vista do rio Corumbataí, em período chuvoso, com alta turbidez, na altura de uma extração de areia em leito de rio, atividade usual na região.

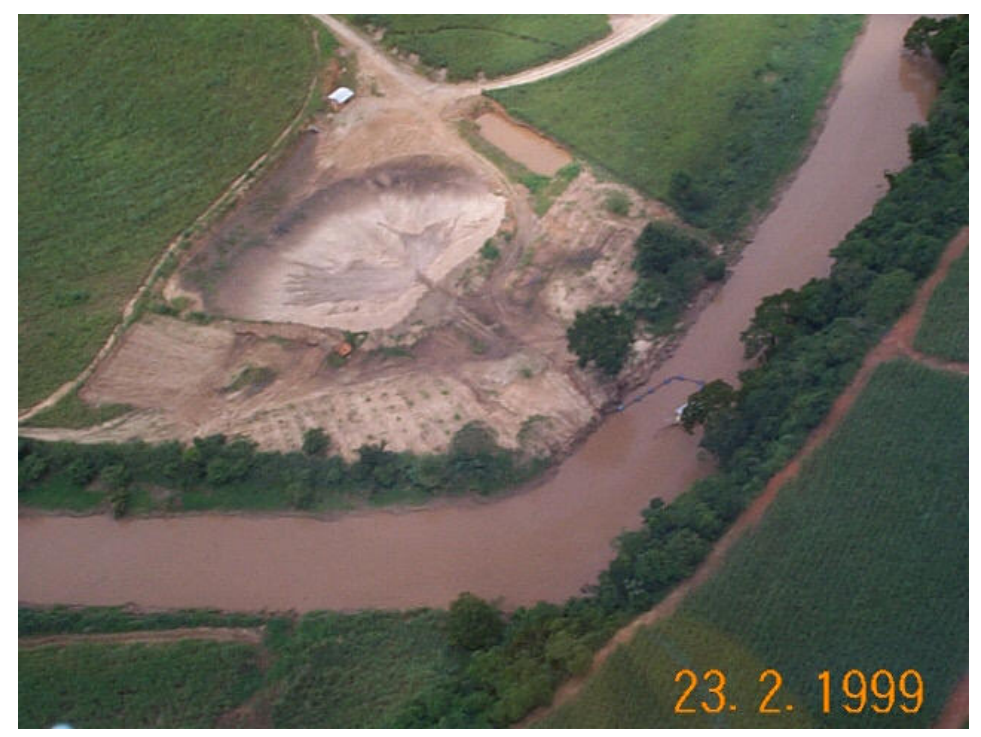

Figura 5 - Vista aérea do rio Corumbataí em fevereiro de 1999, na altura de porto de areia com extração no leito do rio. 
Os dados principais da estação de tratamento e de características do manancial de captação estão descritos no Quadro 5.

\begin{tabular}{|c|c|}
\hline Nome & Estação de Tratamento de Água Capim Fino - ETA 3 \\
\hline Município & Piracicaba \\
\hline Manancial de Captação & rio Corumbataí \\
\hline Área da bacia & $1.710 \mathrm{Km}^{2}$ \\
\hline $\begin{array}{r}\text { Percentual de Cobertura florestal na } \\
\text { bacia }\end{array}$ & $12 \%$ * \\
\hline Tipo de processo de tratamento & convencional \\
\hline Etapas de Tratamento & $\begin{array}{l}\text { pré-cloração, adição de coagulantes, mistura rápida, } \\
\text { coagulação-floculação, } \\
\text { decantação convencional, filtração;desinfecção final, } \\
\text { controle de pH e fluoretação. }\end{array}$ \\
\hline Vazão de água produzida & $129.600 \mathrm{m3} / \mathrm{dia} ; 5400 \mathrm{m3} / \mathrm{h} ; 1.500$ litros/s \\
\hline População abastecida & 330.000 habitantes \\
\hline Produtos químicos utilizados & $\begin{array}{l}\text { cal e cloreto férrico nas etapas de mistura rápida e } \\
\text { coagulação/floculação; cloro gasoso na desinfecção final e } \\
\text { ácido fluossilícico na água tratada para distribuição; o } \\
\text { carvão ativado e o polieletrólito são usados eventualmente }\end{array}$ \\
\hline $\begin{array}{r}\text { Turbidez média da água bruta (abril a } \\
\text { outubro) }\end{array}$ & 28 NTU (2001) e 23 NTU (2002) \\
\hline $\begin{array}{r}\text { Turbidez média da água bruta } \\
\text { (novembro a março) }\end{array}$ & 108 NTU (2001) e 106 NTU (2002) \\
\hline Base de dados & anos 2001 e 2002 \\
\hline
\end{tabular}

Quadro 5-. Estação de Tratamento de Água Capim Fino - ETA 3 e seu manancial de captação

${ }^{*}$ Fonte: IPEF \& SEMAE (2001)

\subsubsection{Estação de Tratamento de Água Luiz de Queiroz do município de Piracicaba e seu manancial de captação}

A ETA 1 - Luiz de Queiroz pode tratar água proveniente de duas captações: a Captação 1, localizada à Av. Bandeirantes, que capta água do rio Piracicaba, e a Captação 3, localizada próxima a Usina Costa Pinto, que capta água do rio Corumbataí, que também atende a ETA Capim Fino - ETA 3.

O SEMAE usualmente assume que sua captação atualmente ocorre apenas no rio Corumbataí; entretanto o rio Piracicaba eventualmente ainda contribui com pequena parte da vazão das águas de abastecimento público do município de 
Piracicaba.

O sistema de tratamento obedece ao padrão convencional, diferenciandose do processo descrito para a ETA Capim Fino - ETA 3 apenas quanto à qualidade dos filtros utilizados após a decantação, sendo esses filtros de gravidade de camada simples, possuindo somente areia na camada filtrante.

Os dados principais da estação de tratamento e de características do manancial de captação estão descritos no Quadro 6.

\begin{tabular}{|c|c|}
\hline Nome & $\begin{array}{l}\text { Estação de Tratamento de Água Luis de Queiroz - } \\
\text { ETA } 1\end{array}$ \\
\hline Município & Piracicaba \\
\hline Manancial de Captação & rio Piracicaba \\
\hline Área da bacia & $3.770 \mathrm{Km}^{2}$ \\
\hline $\begin{array}{r}\text { Percentual de Cobertura florestal } \\
\text { na bacia }\end{array}$ & $4,30 \%$ * \\
\hline Tipo de processo de tratamento & $\begin{array}{l}\text { : pré cloração, adição de coagulantes, mistura rápida, } \\
\text { coagulação-floculação, decantação convencional, } \\
\text { filtração, adição de carvão ativado e desinfecção final. }\end{array}$ \\
\hline \multicolumn{2}{|l|}{ Etapas de Tratamento } \\
\hline Vazão de água produzida & 39.000. m³/dia; $1.625 \mathrm{m3} / \mathrm{h} ; 450$ litros/s \\
\hline População abastecida & - \\
\hline Produtos químicos utilizados & $\begin{array}{l}\text { cal e cloreto férrico nas etapas de mistura rápida e } \\
\text { coagulação/floculação; cloro gasoso na desinfecção } \\
\text { final e ácido fluossilícico na água tratada para } \\
\text { distribuição; o carvão ativado é freqüentemente utilizado }\end{array}$ \\
\hline $\begin{array}{r}\text { Turbidez média da água bruta } \\
\text { (abril a outubro) }\end{array}$ & 19,90 FTU (2001) e 16 FTU (2002) \\
\hline $\begin{array}{r}\text { Turbidez média da água bruta } \\
\text { (novembro a março) }\end{array}$ & 62,40 FTU (2001) e 74 FTU (2002) \\
\hline Base de dados & anos 2001 e 2002 \\
\hline
\end{tabular}

Quadro 6. Estação de Tratamento de Água Luis de Queiroz - ETA 1 e seu manancial de captação *Fonte: São Paulo (2000)

A Figura 6 apresenta uma vista do rio Piracicaba em época de estiagem, na altura do salto do rio, próximo ao Engenho Central e a Figura 7 mostra uma vista aérea do mesmo rio, no mesmo ponto, em época de chuvas. A alteração da turbidez das águas do rio nas duas estações é grande, assim como a alteração na vazão, que fica muito reduzida na estiagem. Com a redução da vazão e a manutenção das cargas poluidoras, os parâmetros de qualidade das águas do rio Piracicaba demonstram o 
comprometimento de suas águas e os níveis de oxigênio chegam a valores próximos de zero, com freqüentes mortandades de peixes.

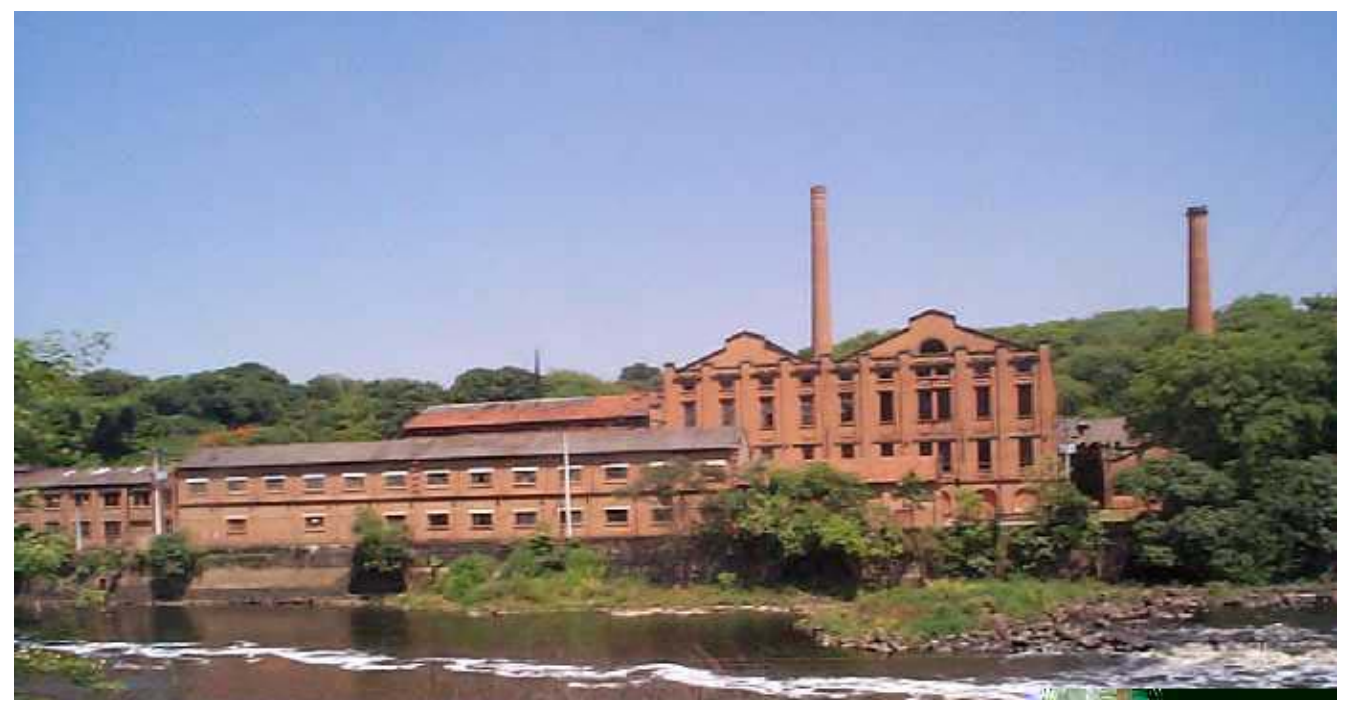

Figura 6 -Rio Piracicaba na altura do Engenho Central na estiagem

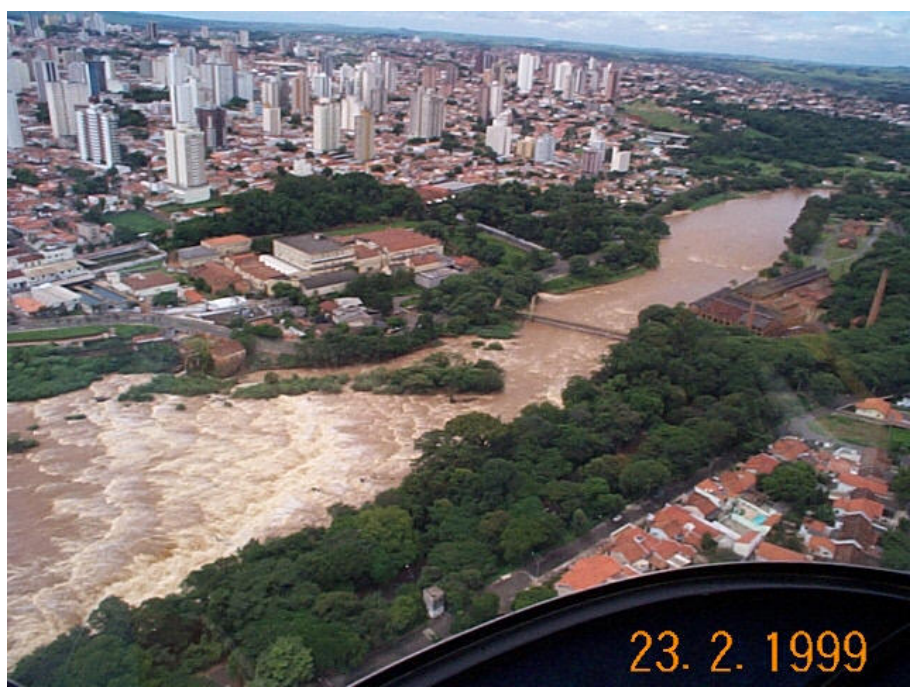

Figura 7 -Vista aérea do rio Piracicaba na altura do salto em época de chuva 


\subsubsection{Estações de tratamento de água da SANASA do município de Campinas e seu manancial}

A Sociedade de Abastecimento de Água e Saneamento S/A, a SANASA, é uma empresa de economia mista, cujo acionista majoritário é a Prefeitura Municipal de Campinas. Ela é responsável pelo serviço de abastecimento de água (captação, adução, tratamento, reservação e distribuição de água potável), coleta, afastamento e tratamento dos esgotos domésticos do município de Campinas.

A captação de água no rio Atibaia é única e existem quatro Casas de Bombas que dirigem a água bruta para as ETAs 1 e 2 no bairro Swift e para as ETAs 3 e 4 na estrada de Sousas. O município possui ainda uma captação de água bruta no rio Capivari, dirigida à ETA 5, situada junto à rodovia dos Bandeirantes. O conjunto de estações de tratamento de água tem capacidade de produção de até 4500 litros/segundo, sendo que cerca de $95 \%$ da água provém do rio Atibaia, 4100 litros/segundo e $5 \%$ do rio Capivari, 360 litros/segundo.

Neste estudo serão analisados apenas os dados dos conjuntos de ETAs, que tratam as águas captadas no rio Atibaia, ou seja, ETAs 1,2,3 e 4.

As captações de água bruta da SANASA possuem desarenadores situados a montante das bombas de elevação da água para as ETAs. O valor da conta de energia das captações de água bruta é equivalente ao valor da conta de iluminação pública de toda a cidade de Campinas.

Os sistemas de tratamento das ETAs são do tipo convencional, diferenciando-se do processo já descrito para a ETA Capim Fino - ETA 3 do município de Piracicaba, apenas pela inexistência de pré cloração da água bruta, a adição de carvão ativado na chegada da água bruta e de amônia anidra juntamente com o cloro à água tratada, antes da distribuição.

Os dados principais da estação de tratamento e de características do manancial de captação estão descritos no Quadro 7. 


\begin{tabular}{|c|c|}
\hline Nome & $\begin{array}{l}\text { Conjunto de ETAs } 1 \text { e } 2 \text { (na Swift); Conjunto de ETAs } \\
\text { 3 e } 4 \text { (na estrada de Sousas) }\end{array}$ \\
\hline Município & Campinas \\
\hline Manancial de Captação & rio Atibaia \\
\hline Área da bacia & $2.820 \mathrm{Km}^{2}$ \\
\hline $\begin{array}{r}\text { Percentual de Cobertura florestal na } \\
\text { bacia }\end{array}$ & $8,22 \%$ * \\
\hline Tipo de processo de tratamento & . convencional \\
\hline Etapas de Tratamento & $\begin{array}{l}\text { adição de carvão ativado, adição de coagulantes, } \\
\text { mistura rápida, } \\
\text { coagulação-floculação, decantação convencional, } \\
\text { filtração; desinfecção } \\
\text { final e fluoretação. }\end{array}$ \\
\hline Vazão de água produzida & $\begin{array}{l}\text { ETAs } 1 \text { e } 2: 1.200 \text { litros/s; } 103.680 \mathrm{m3} / \mathrm{dia} ; 4320 \mathrm{m3} / \mathrm{h}, \\
\text { ETAs } 3 \text { e } 4: 2.900 \text { litros } / \mathrm{s} ; 250.560 \mathrm{~m} 3 / \mathrm{dia} ; 10.440 \mathrm{~m} 3 / \mathrm{h}\end{array}$ \\
\hline População abastecida & 911.800 habitantes \\
\hline Produtos químicos utilizados & $\begin{array}{l}\text { carvão ativado na chegada da água bruta; cal e cloreto } \\
\text { férrico nas etapas } \\
\text { demistura rápida e coagulação/floculação; cloro líquido e } \\
\text { amônia anidra na desinfecção final, ácido fluossilícico, } \\
\text { na água tratada para distribuição }\end{array}$ \\
\hline $\begin{array}{r}\text { Turbidez média da água bruta (abril a } \\
\text { outubro) }\end{array}$ & 30 NTU \\
\hline $\begin{array}{r}\text { Turbidez média da água bruta (novembro } \\
\text { a março) }\end{array}$ & 127 NTU \\
\hline Base de dados & Ano 2002 \\
\hline
\end{tabular}

Quadro 7. - Conjunto de ETAs 1 e 2 (na Swift); Conjunto de ETAs 3 e 41 e seu manancial de captação *Fonte: São Paulo (2000)

\subsubsection{Estações de tratamento de água da SABESP/Sistema Produtor Alto Cotia da Região Metropolitana de São Paulo e seu manancial}

A Companhia Estadual de Saneamento Básico do Estado de São Paulo SABESP é responsável pela adução, tratamento e distribuição da água para consumo humano, assim como pela coleta, afastamento e tratamento dos esgotos domésticos para a Região Metropolitana de São Paulo.

A SABESP opera seus sistemas produtores de água de forma integrada. A Sabesp produz cerca de 65 mil litros de água por segundo para atender os habitantes da região metropolitana de São Paulo. São 31 cidades operadas, além de 7 municípios 
(Santo André, São Bernardo do Campo, São Caetano do Sul, Guarulhos, Mogi das Cruzes, Diadema e Mauá), que compram água da empresa por atacado. O sistema produtor de água do Alto Cotia integra a rede de sistemas produtores de água para o abastecimento da Região Metropolitana de São Paulo.

O sistema Cotia utiliza dois mananciais, o Alto e o Baixo Cotia. O Alto Cotia tem um sistema de água de excelente qualidade, captada do reservatório Pedro Beicht e protegida pela Reserva Florestal do Morro Grande, com dez (10) mil hectares de Mata Atlântica. Essa reserva funciona como um filtro, barrando a entrada de nutrientes nas represas. Ainda assim, ocorrem ações humanas que representam ameaças para a área, como pesca e caça predatórias e atividades imobiliárias inadequadas.

A Figura 8 mostra através de imagem de satélite sem especificação a localização da captação e da ETA do Sistema Alto Cotia.

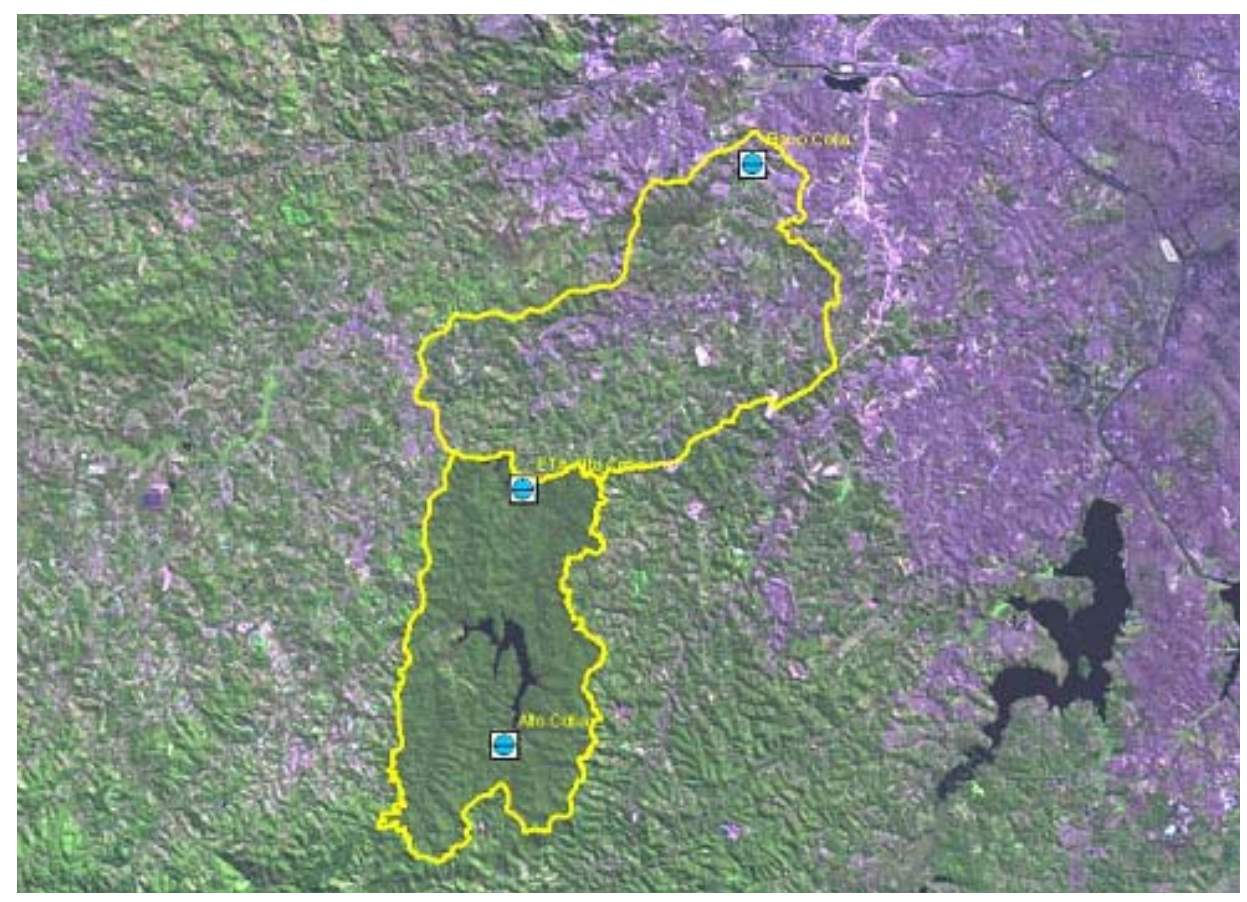

Figura 8-Foto de satélite com localização da captação e ETA do Alto Cotia

A captação de água bruta da SABESP situa-se à Estrada da Barragem, $n^{\circ}$. 515, Bairro Morro Grande, Cotia, SP. As coordenadas geográficas da captação são: 
N - 7382681.541 e S - 299352.484. A vazão captada é de 1.200 Litros/ s.

As águas provenientes do reservatório Pedro Beicht são encaminhadas à Estação de Tratamento de águas do Alto Cotia - ETA Alto Cotia. As coordenadas geográficas da ETA Alto Cotia são: N - 7383100.000 e S - 299900.000. O sistema de tratamento da ETA Alto Cotia é do tipo convencional e abastece 450 mil habitantes de Cotia, Embu, Itapecerica da Serra, Embu-Guaçu e Vargem Grande.

A ETA utiliza sulfato de alumínio em substituição ao cloreto férrico e não utiliza carvão ativado e amônia anidra.

A Figura 9 mostra um fluxograma fornecido pela SABESP para definir as operações que ela utiliza em suas estações de tratamento de água convencionais e na distribuição.

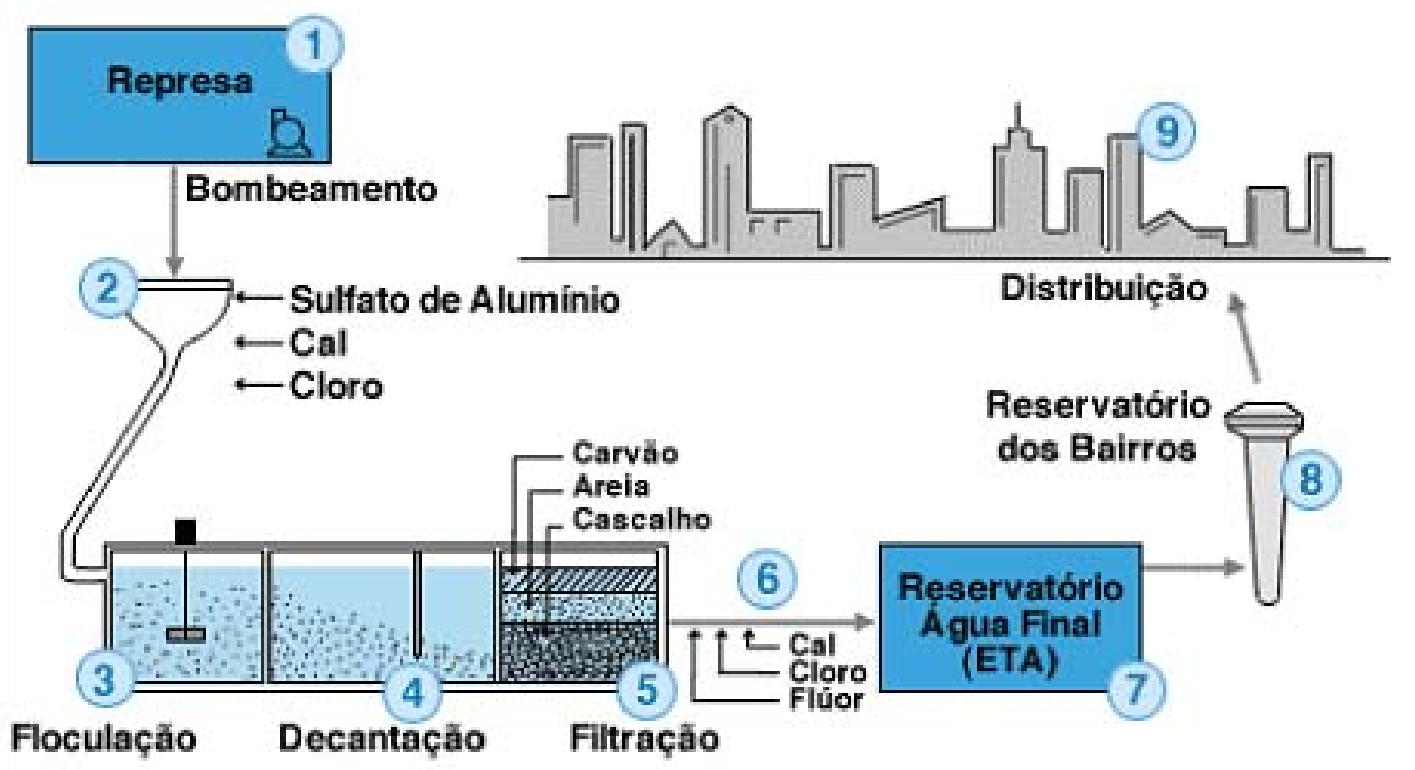

Figura 9- Fluxograma de etapas de tratamento e distribuição de água da SABESP

Os dados principais da estação de tratamento e de características do manancial de captação estão descritos no Quadro 8. 


\begin{tabular}{|c|l|}
\hline Nome & \multicolumn{1}{|c|}{ ETA Alto Cotia } \\
\hline Municípios & Cotia, Embu, Itapecerica da Serra, Embu-Guaçu e Vargem Grande. \\
\hline Manancial de Captação & rio Cotia \\
\hline $\begin{array}{r}\text { Área de da bacia } \\
\text { florestal na bacia }\end{array}$ & Dado não fornecido \\
\hline $\begin{array}{r}\text { Tipo de processo de } \\
\text { tratamento }\end{array}$ & $92 \%$ \\
\hline $\begin{array}{r}\text { Etapas de Tratamento } \\
\text { Vazão de água produzida }\end{array}$ & $\begin{array}{l}\text { Adição de coagulantes e cloro, mistura rápida, coagulaçãofloculação, } \\
\text { decantação convencional, filtração; desinfecção final e fluoretação }\end{array}$ \\
\hline População abastecida & 1.200 litros/s; 129.167 m3/dia; 5.381 m3/h \\
\hline $\begin{array}{r}\text { Produtos químicos utilizados } \\
450.000 \text { habitantes }\end{array}$ & $\begin{array}{l}\text { carvão ativado na chegada da água bruta; cal e cloreto férrico nas } \\
\text { etapas de mistura rápida e coagulação/floculação; cloro na } \\
\text { desinfecção final, flúor na água tratada para distribuição }\end{array}$ \\
\hline $\begin{array}{r}\text { Turbidez média da água } \\
\text { bruta (abril a outubro) }\end{array}$ & 5,2 NTU \\
\hline $\begin{array}{r}\text { Turbidez média da água } \\
\text { bruta (novembro a março) }\end{array}$ & 8,2 NTU \\
\hline Base de dados & Ano 2002 \\
\hline
\end{tabular}

Quadro 8. --ETA Alto Cotia e seu manancial

\subsubsection{Estação de tratamento de água da SABESP/Sistema Cantareira, da Região Metropolitana de São Paulo e seu manancial}

A Região Metropolitana de São Paulo possui cerca de dezessete milhões de habitantes, dos quais nove milhões são abastecidos pelo Sistema Cantareira. O sistema teve sua construção iniciada em 1966. São seis grandes represas, quarenta e oito quilômetros de túneis e canais, uma elevatória de 80.000 HP e uma das maiores estações de tratamento de água da América Latina. Seus represamentos estão situados em diferentes níveis e são interligados de tal maneira que desde as represas do Jaguari e o Jacareí, as águas passam, por gravidade, pelas represas do Cachoeira, Atibainha e Juqueri, e chegam à Estação Elevatória de Santa Inês, onde todo o volume produzido é bombeado para a represa Águas Claras, construída no alto da Serra da Cantareira. As águas passam, por gravidade, para a Estação de Tratamento do Guaraú.

As águas provenientes do Sistema Cantareira são encaminhadas à 
Estação de Tratamento de Água do Guaraú- ETA Guaraú. O sistema de tratamento da ETA Guaraú é do tipo convencional. A Figura 10 mostra os canais de chegada da água à ETA Guaraú. Este é o volume de água retirado das cabeceiras da bacia do rio Piracicaba e atualmente a região vive grande polêmica em torno da renovação da outorga do Sistema Cantareira. Em função da manutenção da retirada de cerca de 31 $\mathrm{m}^{3} / \mathrm{s}$ de água nos períodos de estiagem, particularmente nos últimos 5 anos, as captações municipais a jusante deste sistema têm sofrido com a baixa qualidade dos mananciais, agravada pelas baixas vazões drenadas a jusante do Sistema, em desacordo com valores historicamente estabelecidos, já que os reservatórios têm atingido níveis muito baixos de armazenamento de água.

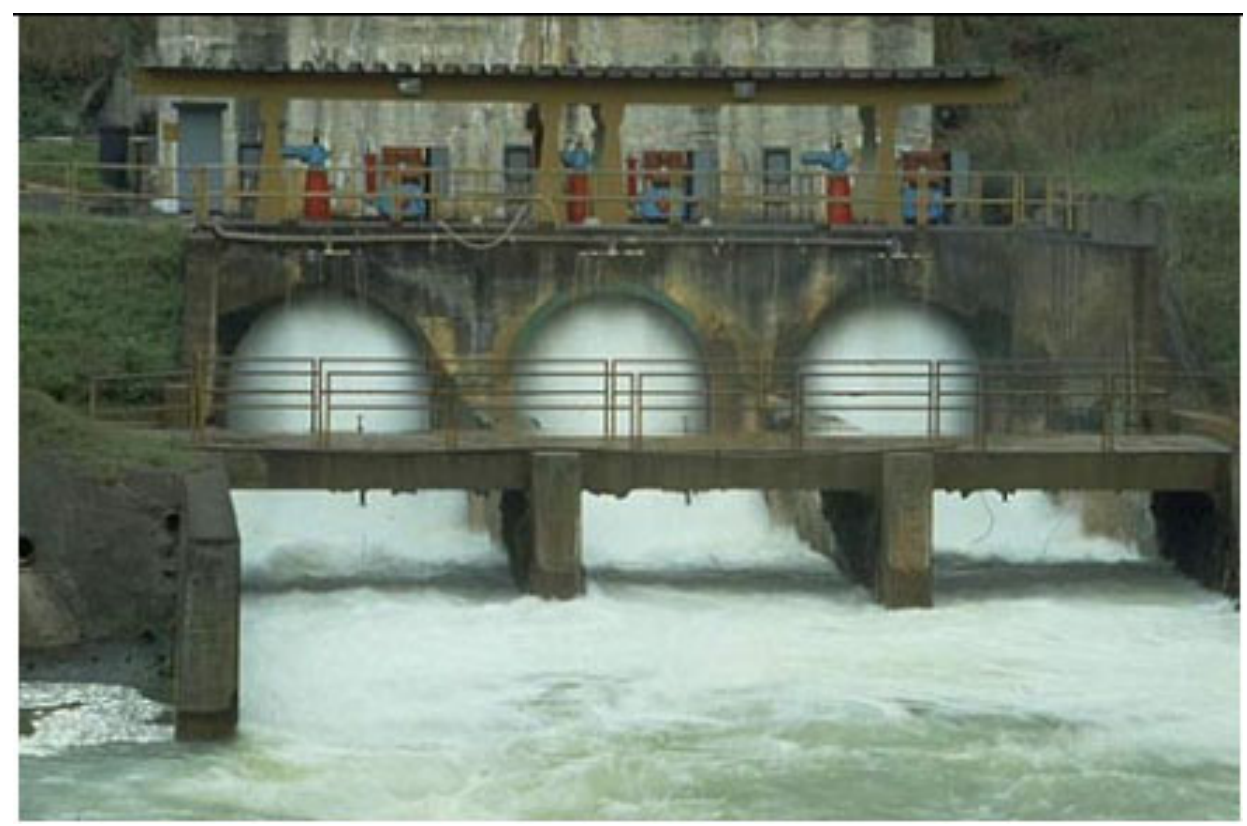

Figura 10 -Chegada da água bruta à ETA Guaraú

A ETA utiliza sulfato de alumínio em substituição ao cloreto férrico e não utiliza carvão ativado e amônia anidra.

A Figura 11, fornecida pela SABESP, mostra o grau de cobertura florestal da bacia de drenagem do sistema Cantareira (exceto Reservatório Paiva Castro), a partir de dados coletados no Projeto Piracena (2003). 


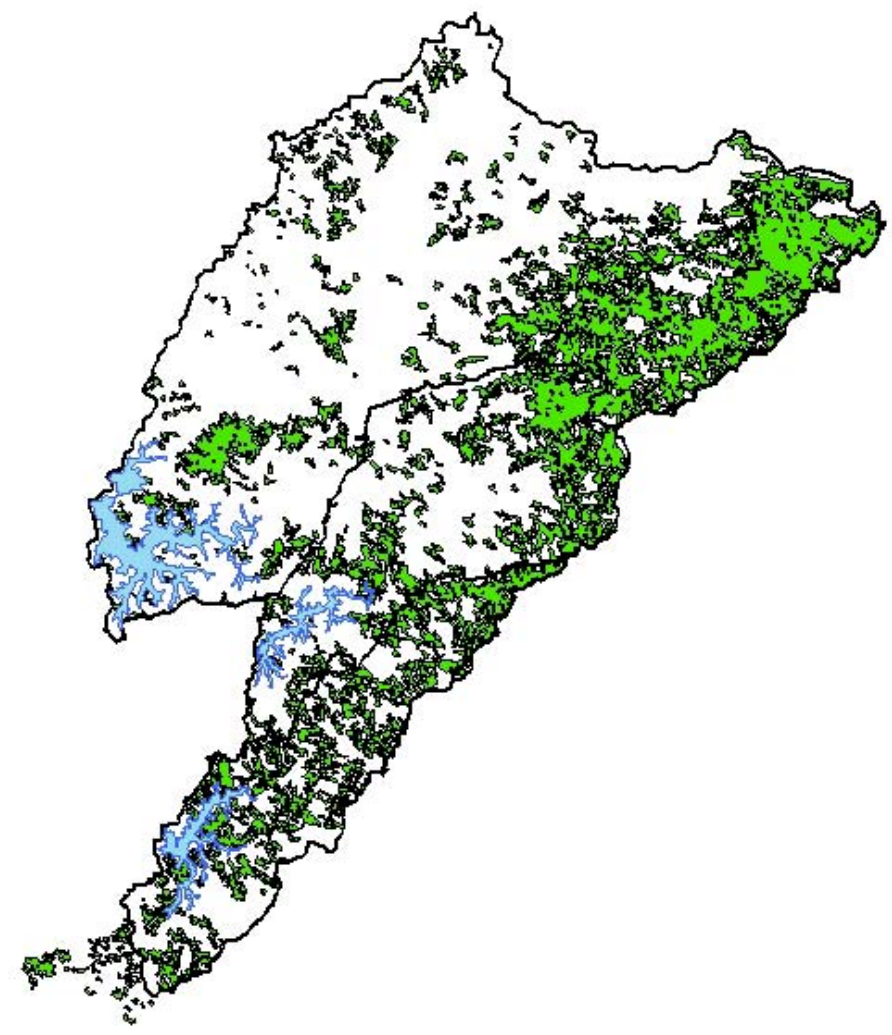

Figura 11-- Imagem da cobertura florestal da bacia de drenagem do Sistema Cantareira fornecida pela SABESP

A Figura 12 apresenta um aspecto de ocupação do solo no entorno das represas do Sistema Cantareira, considerado preocupante pela SABESP. A foto mostra a ocupação das APPs, com diversas intervenções particulares e nenhum replantio de mata ciliar. 


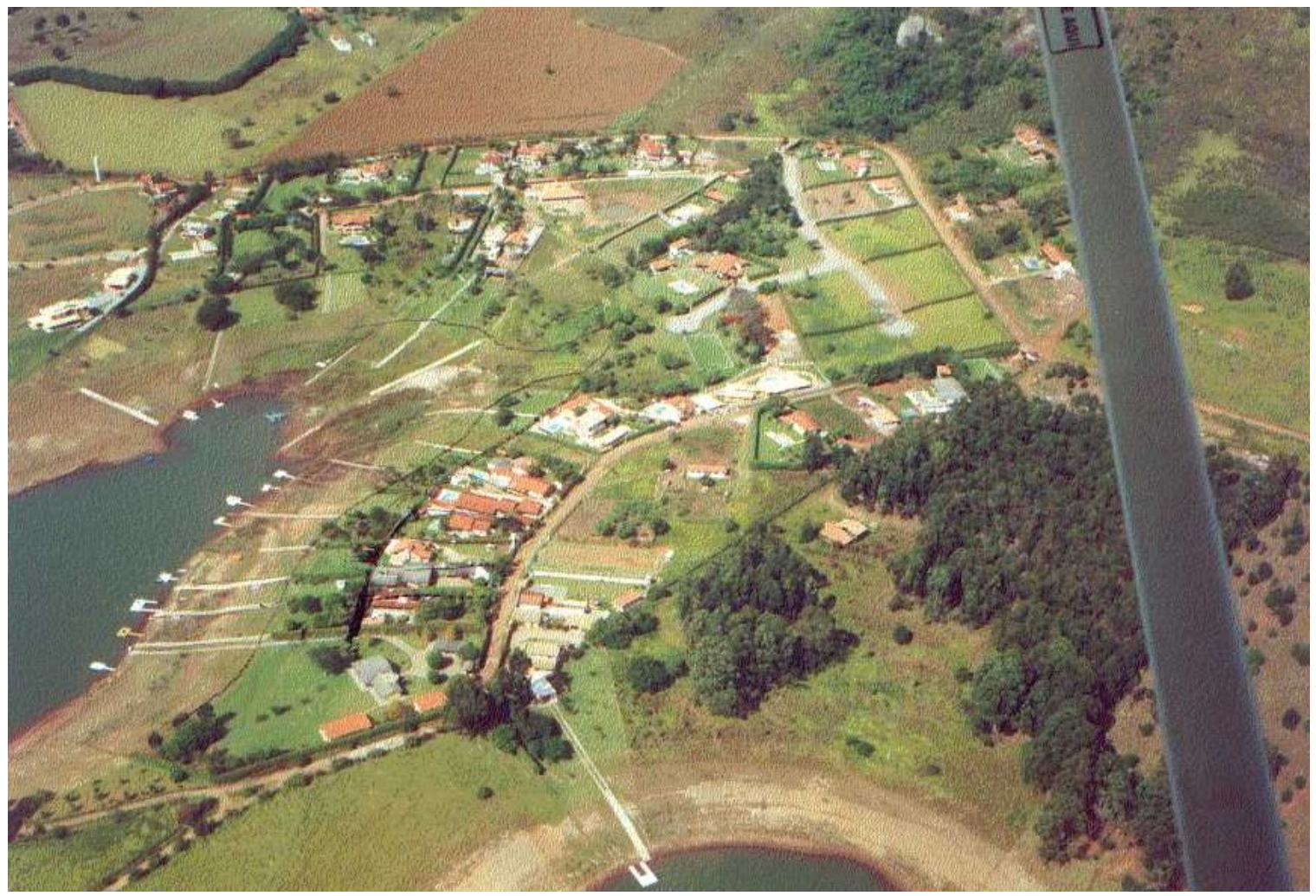

Figura 12-- Vista aérea de ocupação do solo das margens de represa do Sistema Cantareira. Fonte: SABESP

Os dados principais da estação de tratamento e de características do manancial de captação estão descritos no Quadro 9. 


\begin{tabular}{|c|c|}
\hline Nome & \begin{tabular}{|c|} 
ETA Guaraú \\
\end{tabular} \\
\hline Municípios & Região Metropolitana de São Paulo \\
\hline Manancial de Captação & Formadores dos rios Atibaia e Jaguari \\
\hline Área da bacia & $1965 \mathrm{Km}^{2}$ \\
\hline $\begin{array}{r}\text { Percentual de Cobertura } \\
\text { florestal na bacia }\end{array}$ & $27,16 \%$ * \\
\hline Tipo de processo de tratamento & convencional \\
\hline Etapas de Tratamento & $\begin{array}{l}\text { desinfecção, mistura rápida, coagulação- } \\
\text { floculação, decantação convencional, filtração; } \\
\text { correção do pH; desinfecção final e fluoretação }\end{array}$ \\
\hline Vazão de água produzida & $32 \mathrm{~m}^{3} / \mathrm{s} ; 118.800 \mathrm{~m} 3 / \mathrm{h}$ \\
\hline População abastecida & 9.000.000 de habitantes \\
\hline Produtos químicos utilizados & $\begin{array}{l}\text { cloro na chegada da água bruta; cal e sulfato de } \\
\text { alumínio nas etapas de mistura rápida e } \\
\text { coagulação/floculação; cloro na desinfecção final, } \\
\text { flúor na água tratada para distribuição }\end{array}$ \\
\hline $\begin{array}{r}\text { Turbidez média da água bruta } \\
\text { (abril a outubro) }\end{array}$ & 2,7 NTU \\
\hline $\begin{array}{r}\text { Turbidez média da água bruta } \\
\text { (novembro a março) }\end{array}$ & 9,9 NTU \\
\hline Base de dados & ano 2002 \\
\hline
\end{tabular}

Quadro 9-. ETA Guaraú e seu manancial

${ }^{*}$ Fonte: São Paulo (2000)

\subsection{Rio Corumbataí x Rio Piracicaba: perspectivas de manutenção da qualidade de um manancial de abastecimento público}

A rejeição do rio Piracicaba a partir do ano 2000 como principal manancial do município de Piracicaba deu-se em decorrência da sua perda de qualidade e de problemas de manutenção de vazão regular que possibilitasse a captação de águas para o abastecimento público. Os problemas de qualidade e de quantidade da água existentes na bacia hidrográfica do rio Piracicaba são reflexo da ocupação antrópica da bacia, marcada pela conurbação de áreas, presença de extensa malha viária, desenvolvimento econômico acelerado, tudo isso associado a baixos índices de tratamento de esgoto doméstico, alta carga de poluição industrial, intensa atividade agrícola, poluição difusa não caracterizada, solos frágeis, ausência de boas práticas de conservação do solo e de planejamento adequado e omissão dos órgãos públicos responsáveis pelos variados aspectos, principalmente ligados aos recursos 
naturais.

O rio Corumbataí foi então adotado pelo SEMAE de Piracicaba como novo manancial de abastecimento público. O rio Corumbataí já fornecia água para o município desde 1982, mas a partir do ano 2000 passou a ser o único manancial de abastecimento público do município. Todavia, a bacia hidrográfica do rio Corumbataí vem sendo ocupada também de forma desordenada, com reflexos já sentidos na qualidade das águas deste novo manancial.

As duas bacias são assim objeto e material de estudo, ,já que para mostrar as perspectivas sobre a qualidade das águas do rio Corumbataí e atingir o objetivo 2 do trabalho, é necessária a comparação dos aspectos referentes ao meio físico, disponibilidade hídrica e evolução de índices sócio-econômicos, de planejamento municipal e de qualidade das águas do corpo d'água principal entre as duas bacias hidrográficas ao longo do tempo.

As duas unidades de estudo são formadas por:

Unidade 1 de estudo: bacia do rio Piracicaba(contemplada pelas subbacias dos rios Jaguari, Camanducaia, Atibaia e Piracicaba), no universo dos municípios paulistas inseridos na UGRHI 05, excluindo-se os municípios da bacia do rio Corumbataí; a qualidade do rio Piracicaba será avaliada a partir do reflexo da contribuição de toda a bacia a montante do município de Piracicaba, incluindo-se a Região Metropolitana de Campinas.

Unidade 2 de estudo: bacia do rio Corumbataí, no universo dos municípios inseridos na UGRHI 05, inclusive o município de Piracicaba; a qualidade do rio Corumbataí será avaliada a partir do reflexo da contribuição de toda a bacia a montante do município de Piracicaba.

A caracterização física das unidades de estudo é apresentada de forma abrangente, sendo que maior detalhamento poderá ser obtido em Ferraz (2002) ou em São Paulo (2000), para a bacia do rio Piracicaba e em IPEF \& SEMAE (2001), para a bacia do rio Corumbataí.

Muitas das informações, que são importantes para contextualizar a inserção das bacias hidrográficas em estudo no meio, são obtidas para a UGRHI 05 PCJ. Elas serão consideradas para alguns temas como informações válidas para as áreas em estudo, entendendo que não haverá prejuízo de entendimento nesta fase do 
trabalho.

Os mapas apresentados no estudo estão todos na escala 1:50.000, salvo quando houver referência diferenciada.

\subsubsection{Caracterização geográfica e político-administrativa}

\subsubsection{Bacia hidrográfica do rio Piracicaba}

A bacia de drenagem do rio Piracicaba possui uma área de $12.400 \mathrm{Km}^{2}$, sendo que 90\% desse total encontra-se no Estado de São Paulo e o restante no Estado de Minas Gerais, situando-se aproximadamente entre os paralelos $22^{\circ} 00^{\prime} \mathrm{S}$ e $23^{\circ} 30^{\prime} \mathrm{S}$ e os meridianos $45^{\circ} 45^{\prime} \mathrm{W}$ e $48^{\circ} 30^{\prime} \mathrm{W}$ (Ferraz, 2002). A Figura 13 mostra a localização da bacia de hidrográfica do rio Piracicaba no Estado de São Paulo.
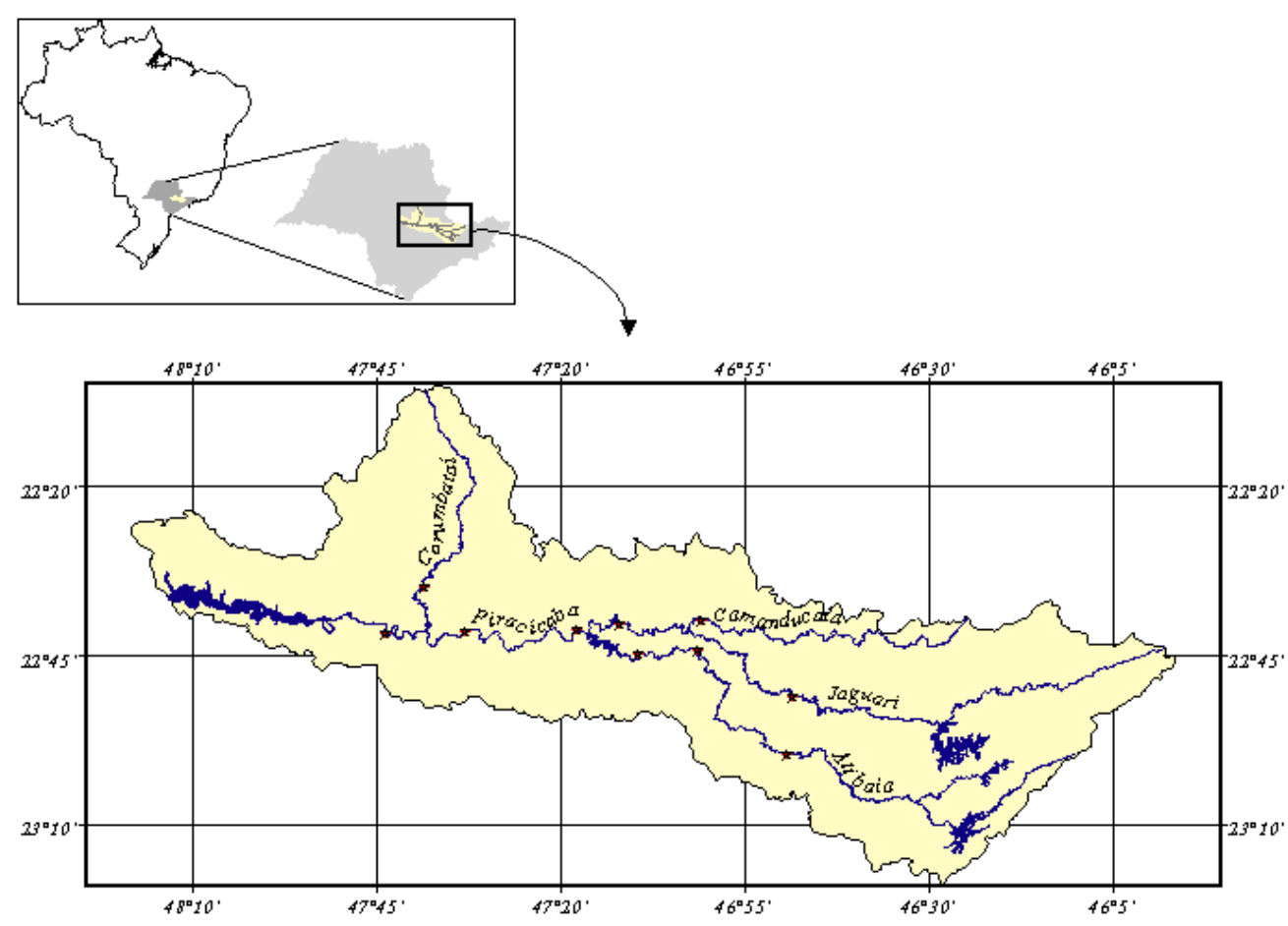

Figura 13- -Localização da bacia hidrográfica do rio Piracicaba no Estado de São Paulo Fonte: PROJETO PIRACENA (2004) 
A bacia hidrográfica do rio Piracicaba é formada pelas seguintes subbacias principais: a sub-bacia do Atibaia, com 2820 Km²; a sub-bacia do Jaguari, com $2180 \mathrm{Km}^{2}$, a sub-bacia do Camanducaia, com 860 Km²; sub-bacia do Piracicaba, com 3770 Km² e sub-bacia do Corumbataí, com $1690 \mathrm{Km}^{2}$. Foram consideradas apenas as porções de área de drenagem inseridas na UGRHI PCJ -05.

Os formadores do rio Piracicaba são os rios Jaguari e Atibaia. O rio Camanducaia é afluente do rio Jaguari. O Corumbataí é o principal afluente do rio Piracicaba, que tem sua foz na altura do município de Piracicaba. Os rios Camanducaia e Jaguari tem suas nascentes situadas no Estado de Minas Gerais, sendo, portanto, considerados rios federais. O rio Piracicaba também é considerado um rio federal, já que uma de suas nascentes é federal. Recentemente estudos realizados pela Agência Nacional das Águas (ANA) demonstraram que o rio Atibaia também é federal, entretanto o CBH-PCJ ainda debate esta afirmativa. Os demais corpos d'água da bacia são de domínio estadual. A Figura 14 mostra a divisão da bacia de drenagem do rio Piracicaba entre suas principais sub-bacias.

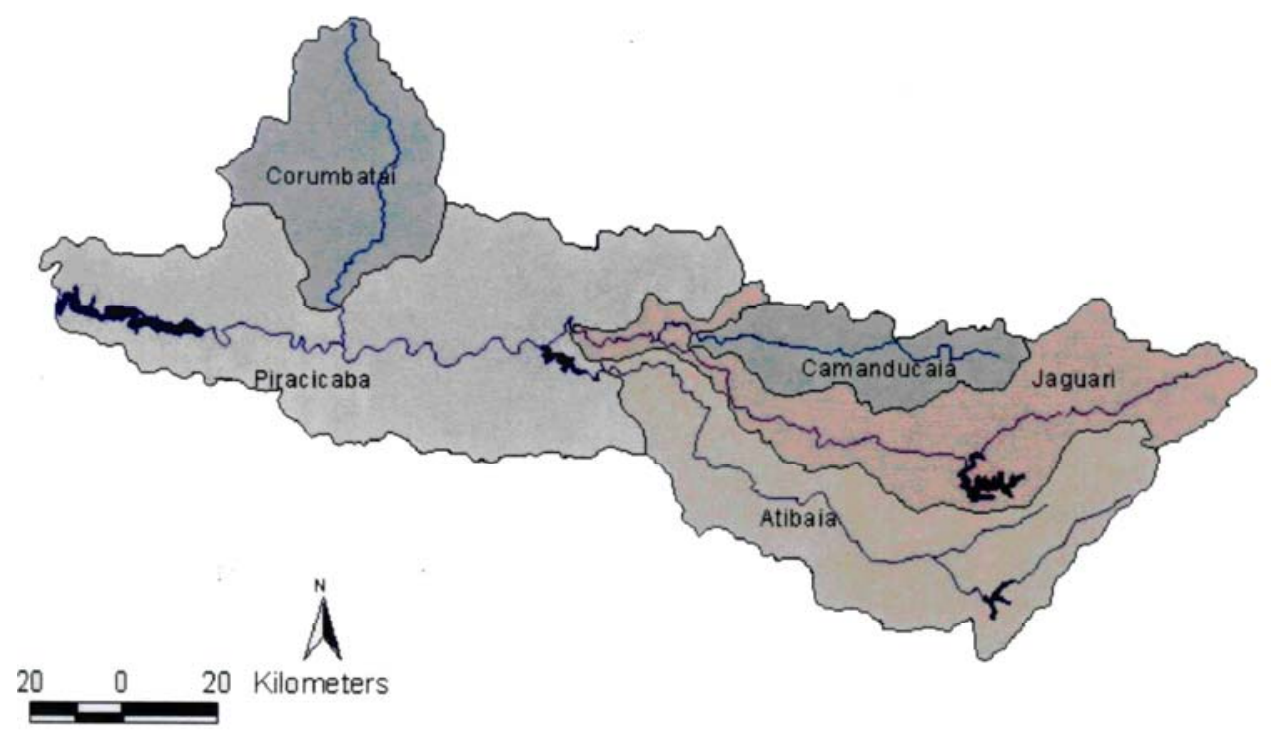

Figura 14--Bacia do rio Piracicaba e suas sub-bacias Fonte: Ferraz (2002)

A identificação dos rios como federais e estaduais é importante, pois a 
cobrança sobre o uso da água está autorizada por legislação para os rios federais sendo que para os rios estaduais a cobrança ainda não está estabelecida, pois o projeto de lei que a regulamenta encontra-se na Assembléia Legislativa do Estado de São Paulo.

A bacia hidrográfica do rio Piracicaba está inserida na Unidade de gerenciamento de recursos hídricos do Estado de São Paulo de número 5 - UGRH 05, que abrange as bacias hidrográficas dos rios Piracicaba, Capivari e Jundiaí. Esta divisão foi estabelecida pelo Decreto estadual $n^{\circ} 38455 / 94$, a partir da Lei estadual 7663/91, que estabelece normas de orientação à Política Estadual de Recursos Hídricos bem como ao Sistema Integrado de Gerenciamento de Recursos Hídricos, SIGRHI. A UGRHI 05 possui instalado, desde 1993, o Comitê de bacias hidrográficas dos rios Piracicaba/Capivari/Jundiaí, CBH-PCJ.

A partir da Lei Federal n. 9433 de 1997, que instituiu a Política Nacional de Recursos Hídricos, estabelecendo o Sistema Nacional de Gerenciamento dos Recursos Hídricos e da Lei Federal n 9.984 de 2000, que criou a Agência Nacional das Águas, entidade federal responsável pela implementação da política e sistema de gerenciamento instituídos, foi instalado o Comitê Federal das bacias hidrográficas dos rios Piracicaba/Capivari/Jundiaí, em 2003.

Os comitês federal e estadual fizeram arranjo institucional de forma a trabalharem dentro de um mesmo fórum de discussão, permitindo a tomada de decisões unificadas. A instalação deste sistema unificado é recente. A UGRHI 05 passa atualmente por momento onde se pretende conciliar a gestão federal, onde a cobrança pelo uso da água já pode ser instituída e a gestão estadual, onde esta cobrança ainda não está em vigência e o projeto de lei que a institui e regulamenta tramita na Assembléia Legislativa do Estado de São Paulo.

A região da UGRHI PCJ concentra uma das redes de infra-estrutura de transportes mais importantes do país. Nela se destacam as rodovias Anhanguera, Bandeirantes, D.Pedro I; a linha tronco da FERROBAN - Ferrovias Bandeirantes S/A e o aeroporto Viracopos, situado no município de Campinas, concentrando o maior volume de carga aérea do país. Essa infra-estrutura favorável contribui com o desenvolvimento econômico da região e estimula a urbanização da região, onde já se verificam tendências à conurbação das cidades. A criação da Região Metropolitana de Campinas, que abrange 18 municípios é exemplo dessa tendência (CBH-PCJ, 2000). 


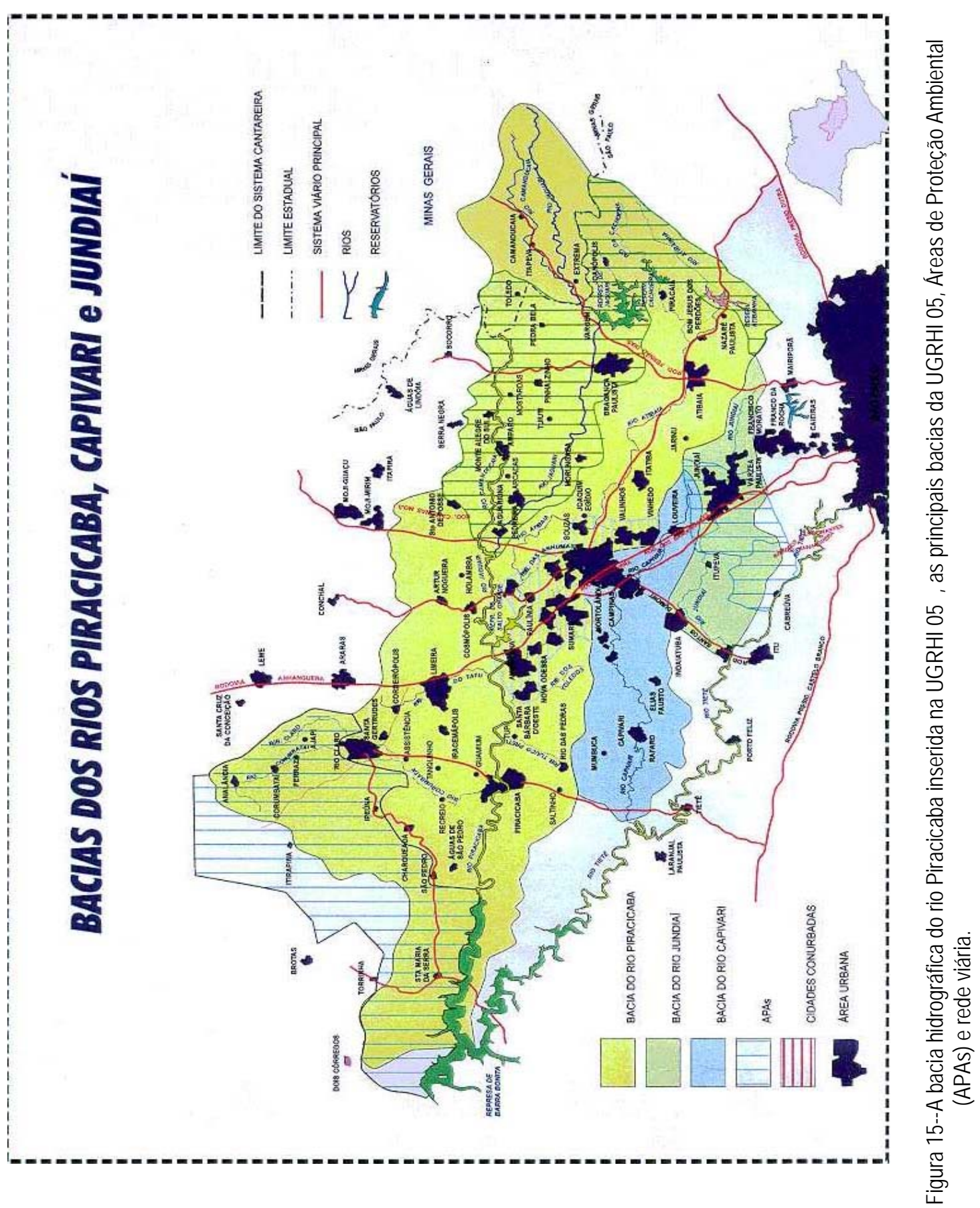


A UGRHI PCJ abrange áreas de 71 municípios: 44 com sede e área total, 14 com sede e área parcial e 13 com sede fora e área parcialmente incluída nas bacias. Somente 58 municípios têm suas sedes localizadas na área compreendida pela UGRHI PCJ. Na região da bacia do rio Piracicaba pertencente ao Estado de Minas Gerais estão as cabeceiras dos rios Jaguari e Camanducaia, onde estão situados os municípios mineiros de Camanducaia, Extrema, Itapeva e Toledo, que juntas possuem cerca de 50 mil habitantes.

\subsubsection{Bacia hidrográfica do rio Corumbataí}

A bacia hidrográfica do rio Corumbataí possui $1.710 \mathrm{Km}^{2}$ de área de drenagem e está localizada entre os paralelos 220 04'46" e $22^{\circ} 41^{\prime 2} 28^{\prime \prime e}$ os meridianos $47^{\circ} 26^{\prime} 23^{\prime \prime}$ e $47^{\circ} 56$ '15", na região Centro Oeste de São Paulo. É uma sub-bacia do rio Piracicaba. O rio Corumbataí é um dos principais afluentes do rio Piracicaba, assumindo importância pela sua capacidade de abastecimento em quantidade e qualidade de água para os oito municípios da bacia. Os municípios que compõe a bacia são: Piracicaba, Rio Claro, Analândia, Corumbataí, Ipeúna, Santa Gertrudes, Charqueada e Itirapina (IPEF, 2001). Os municípios que compõem a bacia do rio Corumbataí e pertencem à UGRHI PCJ são aqueles mencionados, à exceção de Itirapina.

A Figura 16 apresenta a localização da bacia hidrográfica do rio Corumbataí, indicando as sedes dos municípios.

O rio Corumbataí nasce no município de Analândia a aproximadamente 1040 metros de altitude e, após percorrer aproximadamente $110 \mathrm{~km}$, desemboca no rio Piracicaba, no município de Piracicaba a $460 \mathrm{~m}$ de altitude. Seus principais afluentes são os rios Passa Cinco, Cabeça e Ribeirão Claro.

A malha viária da bacia é de aproximadamente 1.130 km de extensão. 


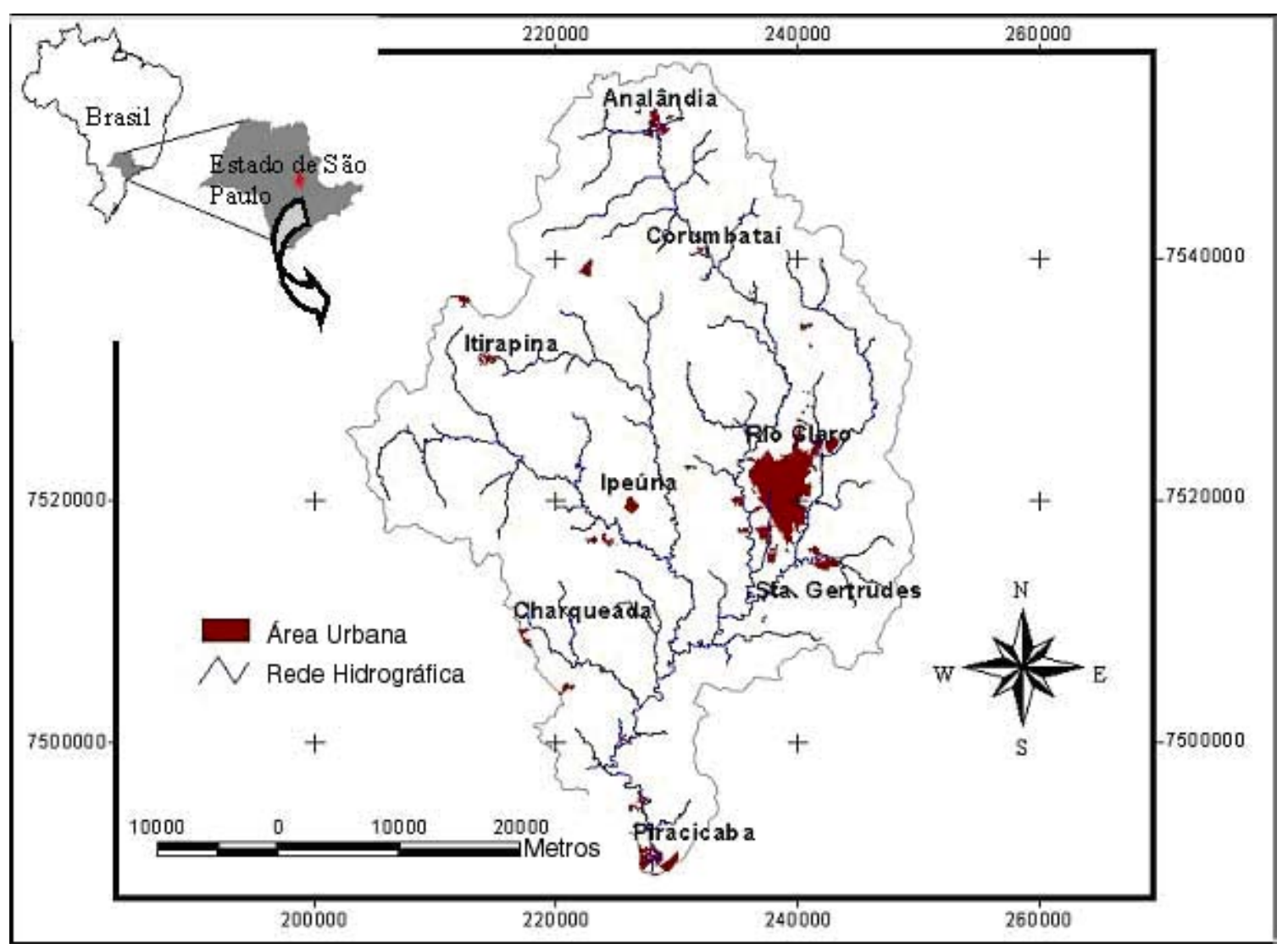

Figura 16--Localização da bacia hidrográfica do rio Corumbataí e sedes dos municípios Fonte: IPEF \& SEMAE (2001)

O IPEF \& SEMAE (2001) definiram cinco sub-bacias dentro da bacia hidrográfica do rio Corumbataí (Figura 17). O Quadro 10 apresenta as áreas de drenagem e o percentual de área que cada uma delas ocupa dentro da bacia hidrográfica do rio Corumbataí. A bacia do rio Corumbataí é estadual e seus municípios estão inseridos no Comitê das bacias dos rios Piracicaba/Capivari/Jundiaí, da UGRHI 05 do Estado de São Paulo. 


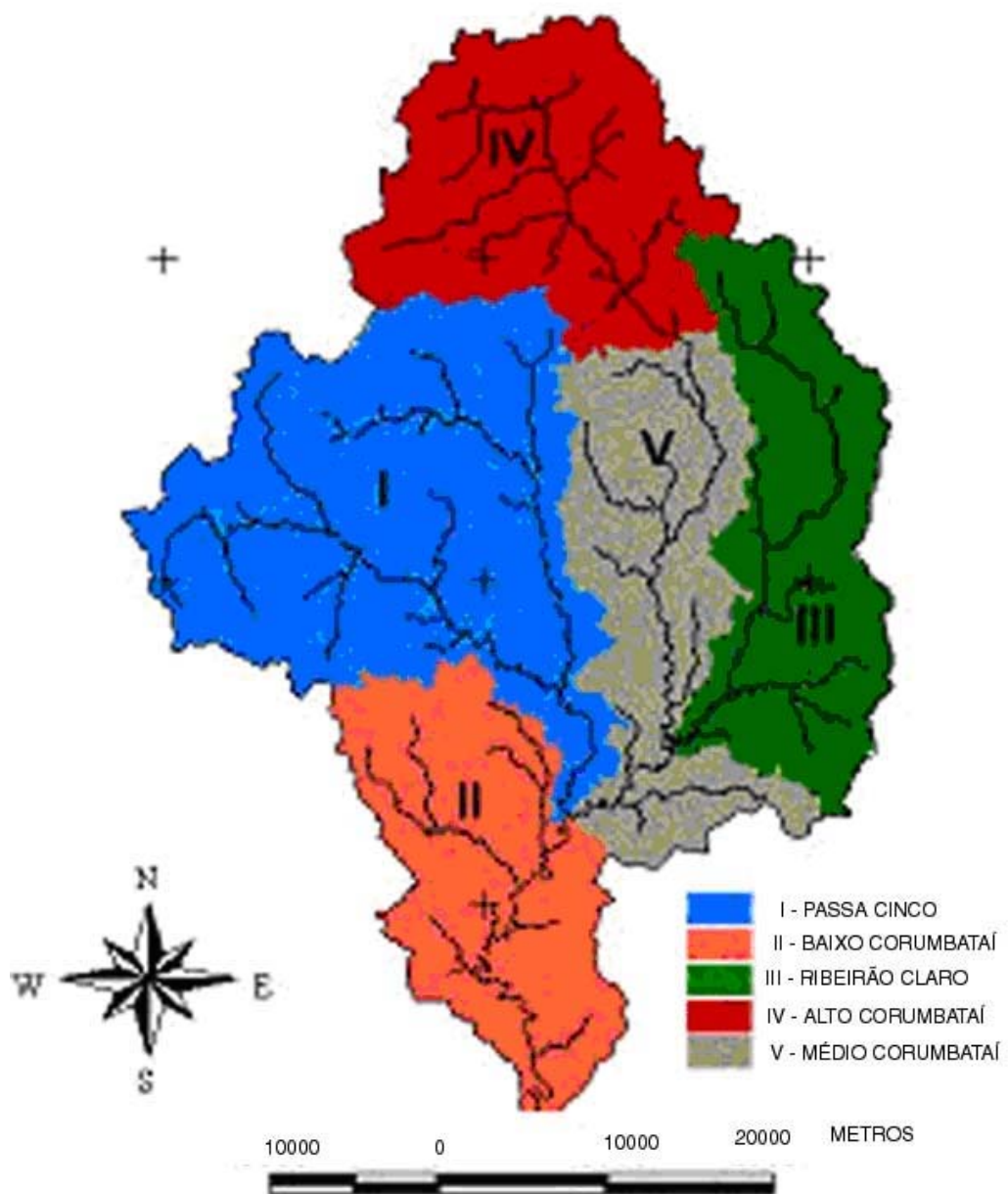

Figura 17- Divisão de sub-bacias da bacia hidrográfica do rio Corumbataí Fonte: IPEF \& SEMAE (2001).

\begin{tabular}{|c|c|c|}
\hline Sub-bacia & Área $\left(\mathrm{Km}^{2}\right)$ & \% da bacia \\
\hline 1 - Passa Cinco & 528 & 31 \\
\hline 2 - Baixo Corumbataí & 287 & 17 \\
\hline 3 - Ribeirão Claro & 281 & 16 \\
\hline 4 - Alto Corumbataí & 318 & 19 \\
\hline 5 - Médio Corumbataí & 293 & 17 \\
\hline TOTAL & 1.707 & 100 \\
\hline
\end{tabular}

Quadro 10 - Áreas das sub-bacias da bacia hidrográfica do rio Corumbataí Fonte: IPEF \& SEMAE (2001) 


\subsubsection{Caracterização Física}

\subsubsection{Bacia hidrográfica do rio Piracicaba}

A bacia de drenagem do rio Piracicaba engloba dois domínios geológicos de naturezas distintas. Dividem-na praticamente em duas metades, tendo as rochas do embasamento cristalino a leste e as seqüências deposicionais da Bacia Sedimentar do Paraná a oeste. As rochas antigas do embasamento, de idades predominantes do Proterozóico, correspondem a complexos cristalinos constituídos por larga variação de termos líticos, como granitóides diversos, rochas básicas diversas, migmatitos, gnaisses, xistos, quartzitos e outros, rochas submetidas a deformações por dobramentos e falhamentos que originaram importantes descontinuidades. Estas são responsáveis, praticamente únicas, pelo condicionamento dos aqüíferos subterrâneos em terrenos cristalinos (IPT, 1981a).

As seqüências da Bacia Sedimentar do Paraná na bacia hidrográfica do Piracicaba são representadas por sedimentos paleozóicos dos grupos Tubarão e Passa-Dois e por sedimentos e rochas magmáticas intrusivas mesozóicas do Grupo São Bento (Formações Pirambóia, Botucatu e Serra Geral) e do grupo Bauru. Coberturas sedimentares cenozóicas, destacando-se depósitos da Formação Rio Claro e correlatos à Formação Itaqueri, completam o quadro geológico da área. Falhamentos também afetaram as seqüências tipicamente horizontalizadas da Bacia do Paraná. O condicionamento de aqüíferos subterrâneos tem influência dessas estruturas, mas com relevante participação da porosidade típica dos sedimentos, principalmente de arenitos e termos mais grossos, que referenciam os pacotes armazenadores mais importantes (IPT, 1981a).

O relevo da bacia do Piracicaba é condicionado diretamente pelo substrato, de tal modo que a leste, domínio das rochas resistentes do cristalino, desenvolvem-se as morrarias e serranias do Planáltico Atlântico, formas de relevo sempre com declividades altas, em média 15\%, e altitudes variando de 600 a 2.000 metros (São Paulo, 1996; Ferraz, 2002). A rede de drenagem é de alta densidade, com forte tendência a controle por estruturas geológicas, com inúmeros ramos primários 
entalhando as encostas e avançando até próximo dos limites das cumeadas. Processos erosivos laminares e por ravinamento ocorrem generalizadamente. Movimentos de massa são frequentes, condicionados pelos fortes declives dominantes e refletem a predisposição natural do relevo a tais processos.

A metade ocidental da bacia do Piracicaba desenvolve-se em terrenos da Depressão Periférica, domínio de colinas e morrotes que se estende do Planalto Atlântico até as faldas das Cuestas Basálticas. Esta, uma unidade geomorfológica restrita no extremo oeste da bacia do Piracicaba, é representada por relevo de escarpas festonadas sustentadas por rochas basálticas e arenitos silicificados, tendo suaves colinas em seu reverso imediato (IPT, 1981a).

A Figura 18 mostra as formações geológicas da bacia do rio Piracicaba.

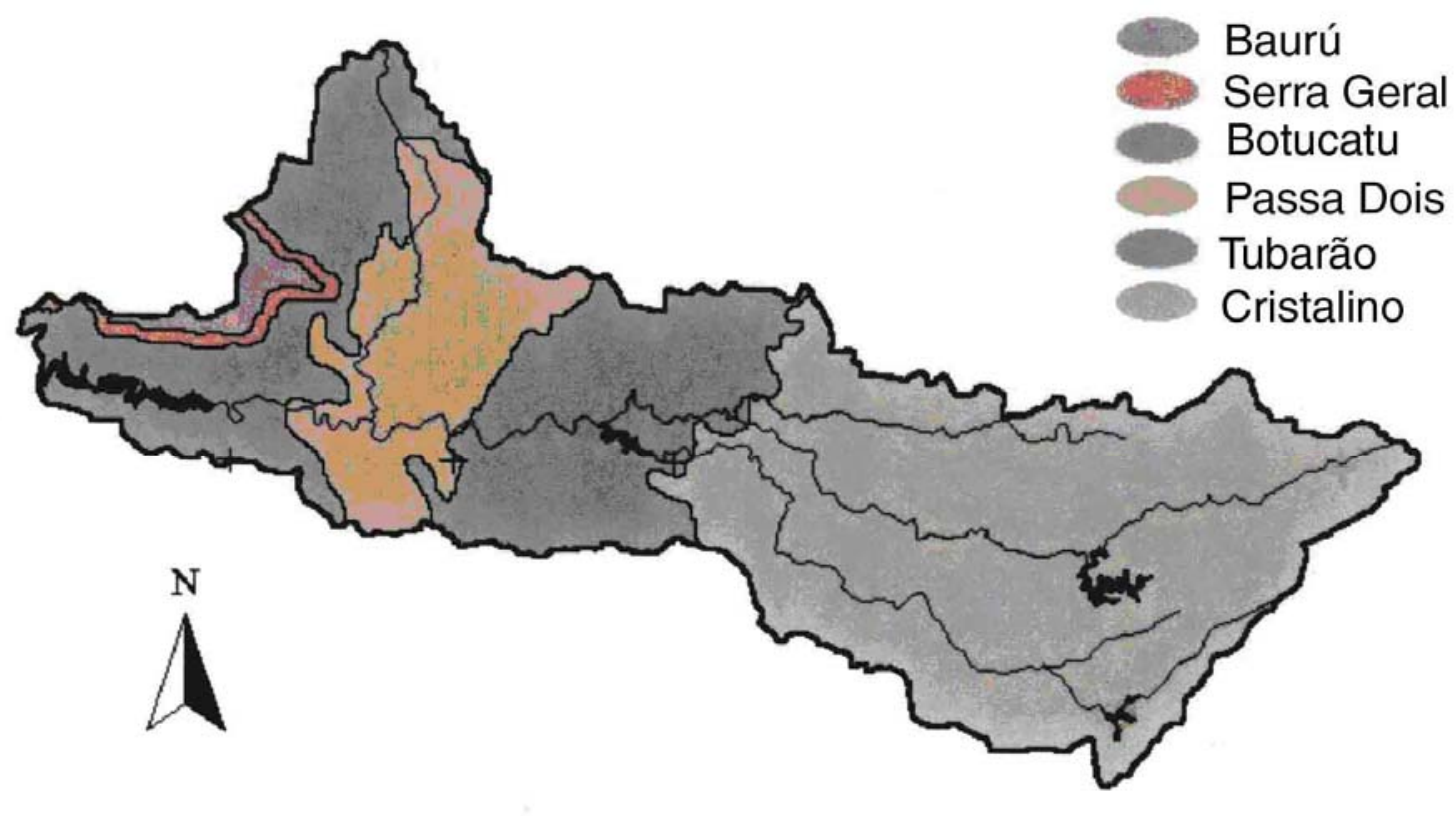

$10 \quad 0 \quad 1020$ KILÔMETROS

Figura 18 - Formações Geológicas da bacia hidrográfica do Rio Piracicaba Fonte: FERRAZ (2002)

O relevo dessa porção da bacia, predominantemente colinoso, tem declividades tanto mais suaves quanto maior a colina, pouco mais acentuadas nas colinas menores e morrotes, ganhando muita inclinação no sopé das escarpas. Morros 
alongados com topos achatados e encostas que alcançam declives muito acentuados são formados no front das escarpas.. Os processos erosivos, laminares, por ravinas e mais restritamente por voçorocas, ocorrem generalizadamente, mais intensos em decorrência de usos dos solos, principalmente em relevos mais acentuados e de substrato arenítico. Movimentos de massa são restritos às escarpas. A rede de drenagem mostra franca tendência dendrítica e densidade média a alta, porém menor, em relação ao Planalto Atlântico (IPT, 1981a).

Os solos da bacia do Piracicaba são representados por dois grandes grupos, Latossolos Vermelho-Amarelo e Podzólicos Vermelho-Amarelo, tendo subordinados Latossolo Vermelho, Latossolo Roxo, Terra Roxa Estruturada, solos hidromórficos, solos litólicos e Areia Quartzosa (São Paulo, 1994).

As coberturas pedológicas nos morros e serras sustentados por rochas cristalinas, do Planalto Atlântico, são predominantemente do grupo latossolo vermelho e subordinadamente do tipo podzólico. Os horizontes superficiais, $A$ e $B$, são normalmente rasos, espessura menor que 1 metro, de textura argilosa e maduros (SP e Ferraz). Sotopostos, os solos de alteração de rocha, do horizonte C, são predominantemente siltosos e de espessuras variadas. Estes, aliados ao manto de rocha alterada, constituem pacotes com espessura que atingem de 5 a 15 metros (São Paulo, 1994).

Nos relevos da Depressão Periférica, a diversidade de rochas sedimentares e a presença de diques de diabásio originam muitos tipos pedológicos, com texturas e composições obedientes ao substrato do qual evoluem, com predomínio de podzólicos vermelhos, ocorrendo subordinadamente os latossolos roxos e vermelhos. Os termos evoluídos a partir de argilitos e siltitos são solos relativamente menos espessos, mesmo assim decimétricos a métricos, ganhando espessura quando sobre colinas amplas sustentadas por arenitos (IPT, 1981b).

No pequeno domínio das Cuestas Basálticas, bem como em elevações sustentadas por diques de diabásio na Depressão Periférica, ocorrem Latossolo Roxo e Terra Roxa Estruturada, predominando espessuras métricas. Escarpas condicionam solos litólicos, enquanto depressões úmidas e planícies de inundação dos cursos d'água condicionam os termos hidromorfizados (IPT, 1981b).

Segundo classificação de Köppen, a predominância do clima na bacia hidrográfica do rio Piracicaba é do tipo Cwa, que indica a média do mês mais frio entre 
$+3^{\circ} \mathrm{C}$ e $+18^{\circ} \mathrm{C}$, seca no inverno e temperatura média do mês mais quente superior a $22^{\circ} \mathrm{C}$. Já a porção situada na serra da Mantiqueira possui clima temperado tipo $D$, segundo a mesma classificação, com temperatura média anual entre $12^{\circ} \mathrm{C}$ e $18^{\circ} \mathrm{C}$ (Ferraz, 2002).

O regime pluviométrico é tropical típico, com período chuvoso iniciandose em outubro e findando em abril, e o de estiagem entre maio e setembro. Os índices de precipitação pluviométrica, na média, variam entre 800 e 2.000 mm anuais (Figura 19). Os dados das precipitações médias mensais existentes nos diversos postos da bacia indicam que os meses menos chuvosos são julho e agosto (médias entre 25 e 40 $\mathrm{mm}$ ), e que as maiores precipitações ocorrem em dezembro e janeiro (médias entre 190 e $270 \mathrm{~mm})(\mathrm{CBH}-\mathrm{PCJ}, 2000)$.

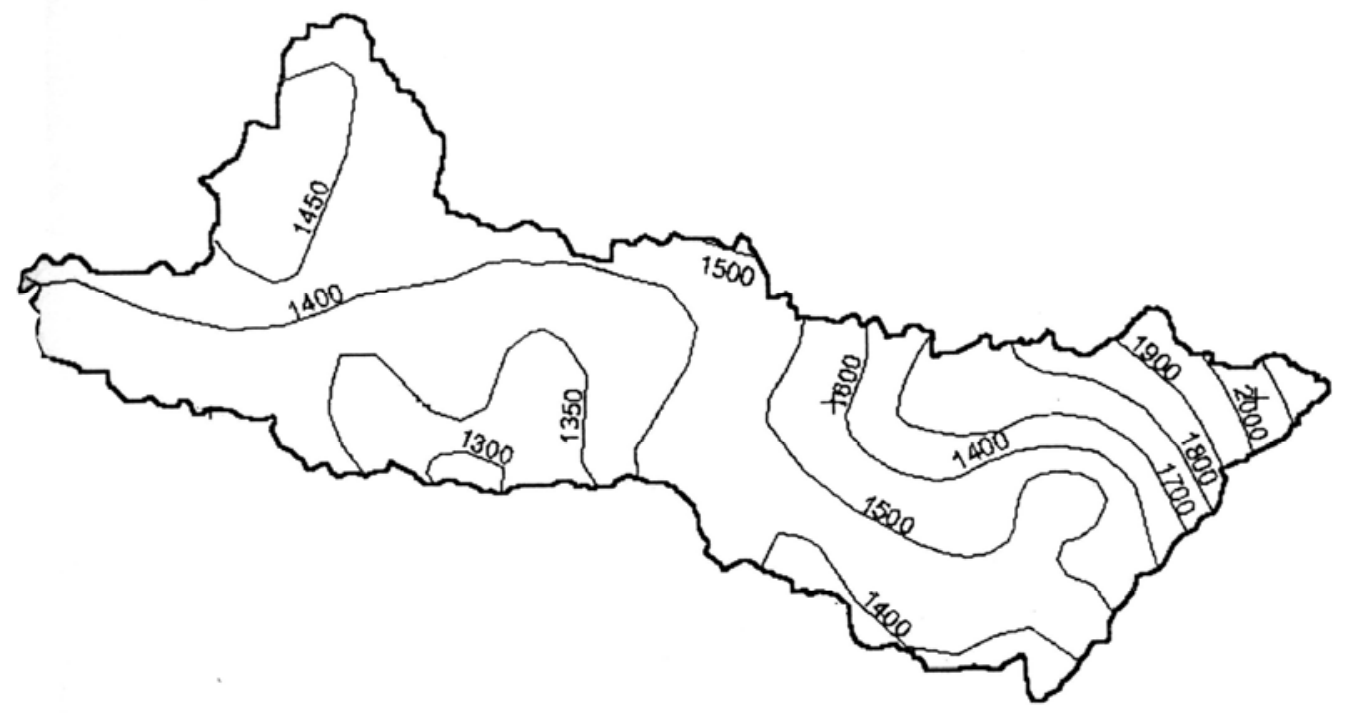

Figura 19- Isoietas anuais em (mm) para a bacia hidrográfica do rio Piracicaba. 1961 a 1992.

Fonte: FERRAZ (2002)

A Figura 20 mostra a rede hídrica da bacia do rio Piracicaba, conforme documentação do Projeto Piracena (2004) e a Figura 21 mostra o mapa de risco à erosão na bacia do rio Piracicaba de 1993. 


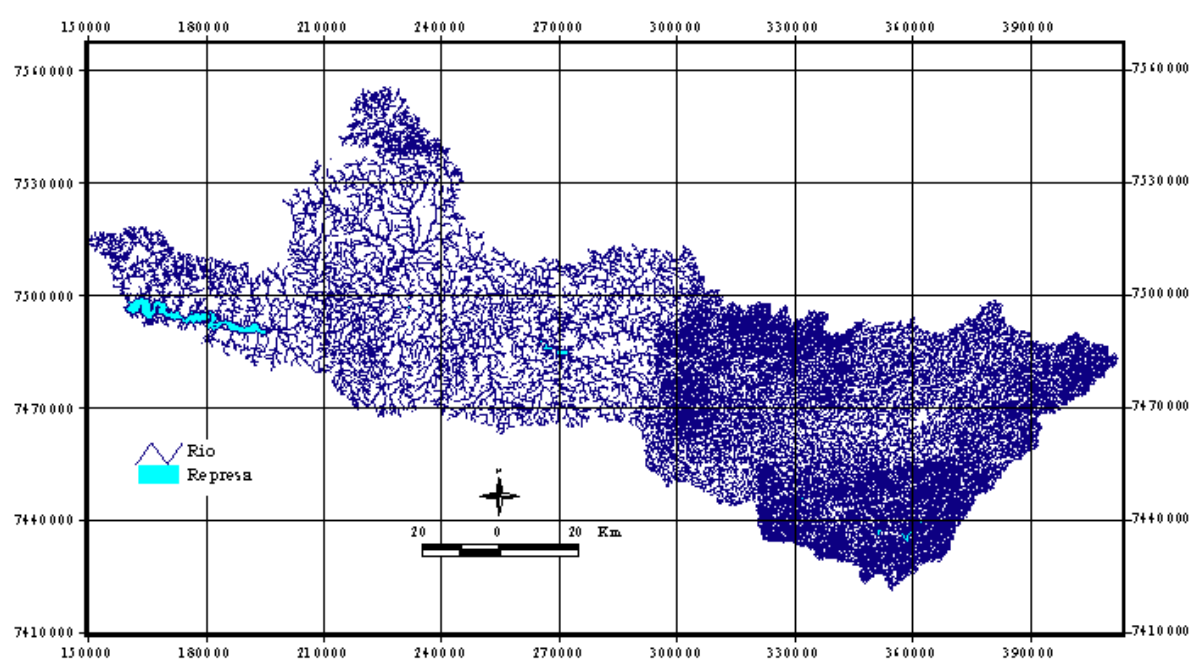

Figura 20- Rede de drenagem da bacia do rio Piracicaba Fonte: Projeto Piracena (2004).

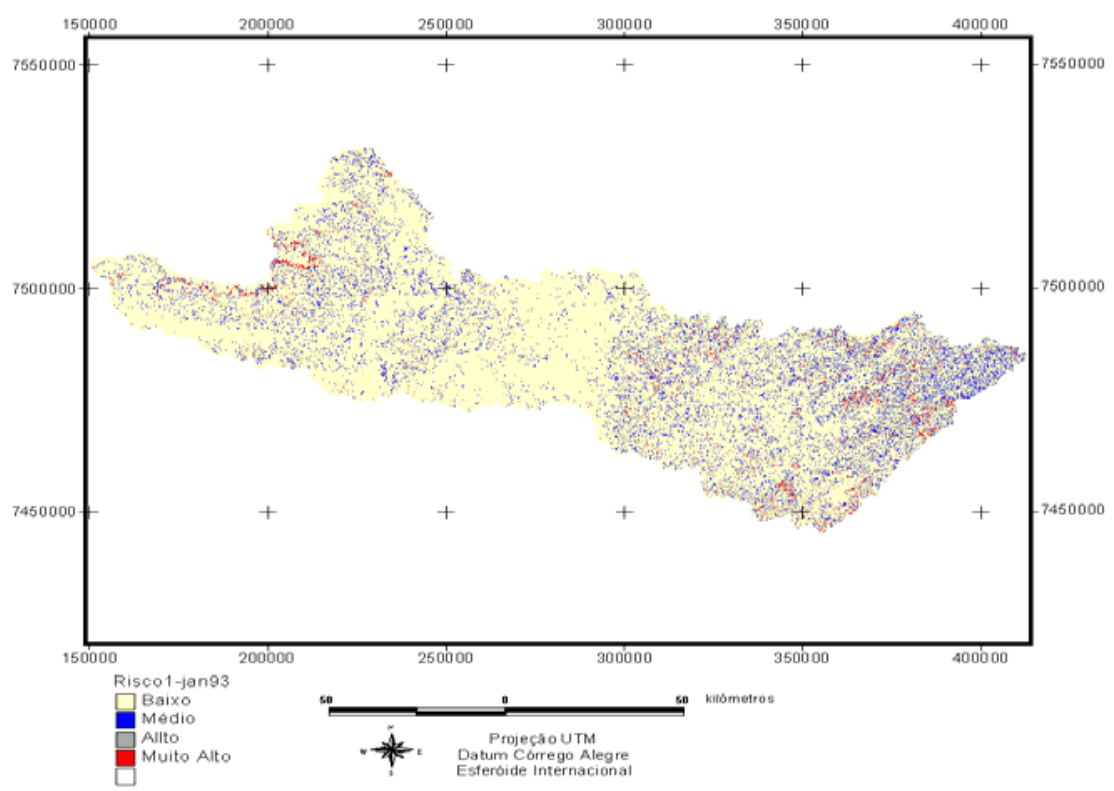

Figura 21- Risco à erosão 1993

Fonte: Projeto Piracena (2004)

\subsubsection{Bacia hidrográfica do rio Corumbataí}


A bacia hidrográfica do rio Corumbataí está localizada na porção centroleste do Estado de São Paulo, em domínios da Bacia Sedimentar do Paraná. Grosso modo, em sua porção oriental o substrato é constituído por rochas paleozóicas, representadas por seqüências predominantemente argilosas das Formações Itararé, Tatuí, Irati e Corumbataí. Na metade ocidental ocorrem as seqüências mesozóicas do Grupo São Bento, com sedimentos predominantemente arenosos das formações Pirambóia e Botucatu e rochas basálticas intrusivas da Formação Serra Geral. As coberturas sedimentares cenozóicas, da Formação Rio Claro e Formação Itaqui, além das coberturas indiferenciadas, estas presentes ao longo das Cuestas Basálticas e correlatas à Formação Itaqueri, completam o empilhamento das unidades geológicas da bacia do Corumbataí. A seqüência termina com depósitos aluviais, e depósitos detríticos, em rampas ao sopé das escarpas (IPT, 1981a).

Geomorfologicamente, em sua maior parte a bacia do Corumbataí está inserida na Província da Depressão Periférica. Restam, pertencentes às Cuestas Basálticas, os terrenos de seus limites de oeste, praticamente no contexto do divisor d'águas que se desenvolve do norte de Charqueada a Analândia (IPT, 1981a).

O relevo predominantemente colinoso da Depressão Periférica mostra diferenciações quando em substrato de argilitos e siltitos, em relação a substrato de arenitos. Basicamente, nos arenitos, são formas mais amplas e de topos mais extensos e achatados, com encostas mais suaves e longas. Nos substratos de argilitos e siltitos as colinas são menores e os declives pouco mais acentuados, mesmo assim moderados a suaves. As escarpas que definem o front das Cuestas Basálticas são sempre íngremes, verticalizadas, de onde partem os divisores secundários que se desfazem paulatinamente à medida que se afastam das escarpas. Formam-se, assim, morros e morrotes isolados que compõem um relevo de declives bem mais fortes (IPT, 1981b).

A Figura 22 permite a visualização das estruturas geológicas da bacia do rio Corumbataí. 


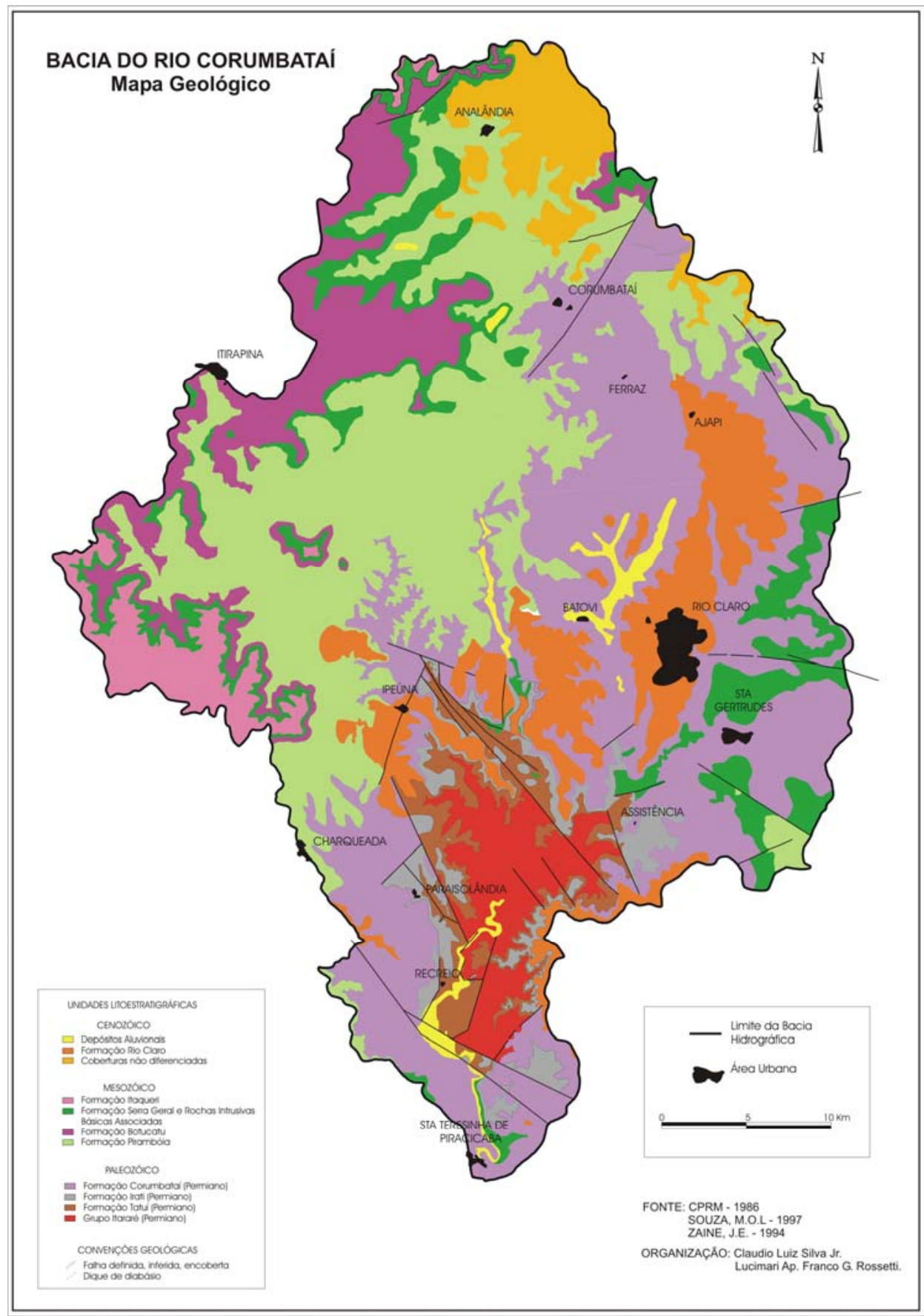

Figura 22 -Mapa Geológico do rio Corumbataí Fonte: UNESP/IGCE/CEAPLA (2004)

A bacia tem 43,46\% de sua área ocupada com solos Podzólicos Vermelho-Amarelos e $21,58 \%$ com Latossolos Vermelho-Amarelos, que constituem os 
grupos de solos predominantes. Nas regiões noroeste e centro-oeste da bacia há extensas áreas com alto risco de erosão. Sobre substratos argilíticos e sílticos dominam os podzólicos e subordinadamente ocorrem latossolos. De modo geral as espessuras dos perfis pedogenéticos são decimétricas a métricas (IPT, 1981b).

Na região a oeste da bacia, Latossolo Roxo e Terra Rocha Estruturada ocorrem associados aos restritos afloramentos de rochas básicas. Em domínios das formações Pirambóia e Botucatu ocorrem os solos mais suscetíveis à erosão, Podzólicos Vermelho-Amarelos, Latossolos Vermelho-Amarelos e Areia Quartzosa. As coberturas pedológicas dessa área atingem as maiores espessuras, principalmente os solos derivados de rochas básicas.. Nas escarpas ocorrem os restritos perfis litólicos. Solos hidromórficos estão condicionados a ambientes alagadiços (UNESP/IGCE/CEAPLA, 2004).

Os processos erosivos são mais intensos e generalizados nos terrenos areníticos, tanto pelos solos de textura arenosa como por situações de declividades mais fortes. Erosão laminar e ravinas ocorrem por toda a bacia, menos marcantes em substratos de rochas finas, mas notórios quando presentes coberturas arenosas mais recentes, como as Formações Rio Claro e Itaqueri. Voçorocas são típicas dos domínios mais amplos de arenitos das formações Pirambóia e Botucatu, onde ocorrem de modo mais significativo. Nos terrenos escarpados são comuns movimentos de massa, geralmente escorregamentos de pequeno porte e rastejos, estes bem mais afeitos aos morros no sopé das escarpas (IPT, 1981a).

Aliando-se as características de substrato rochoso, relevo e solos, percebe-se que a bacia, no todo, apresenta tendência erosiva muito alta. Essa suscetibilidade é muito mais intensa nos terrenos arenosos. Tem-se ainda, potencialidades erosivas muito altas nos relevos mais enérgicos do contexto das escarpas, independentemente do substrato. Desse modo, pode-se considerar muito alta a tendência da bacia do Corumbataí fornecer materiais para a rede de drenagem

O regime pluviométrico é tropical típico, com período chuvoso iniciandose em outubro e findando em abril, e o de estiagem entre maio e setembro. Conforme Zavatini \& Cano (2004), com a análise de medições de pluviosidade entre os anos de 1962 e 1991, observa-se que os mais altos índices pluviométricos encontram-se na porção noroeste da bacia, cujos níveis de altitude estão entre 800 e 1000 m, denotando 
o controle orográfico das precipitações. Os menores índices pluviométricos estão situados ao sul da cidade de Piracicaba, promovendo amplitude da ordem de $250 \mathrm{~mm}$. Os autores verificaram ainda que, nas estações de outono e inverno, a porção central da bacia é a mais chuvosa. A pluviosidade média anual da bacia é de $1400 \mathrm{~mm}$.

A Figura 23 mostra a rede hídrica da bacia do rio Corumbataí e a figura 24 o mapa de risco à erosão da bacia.

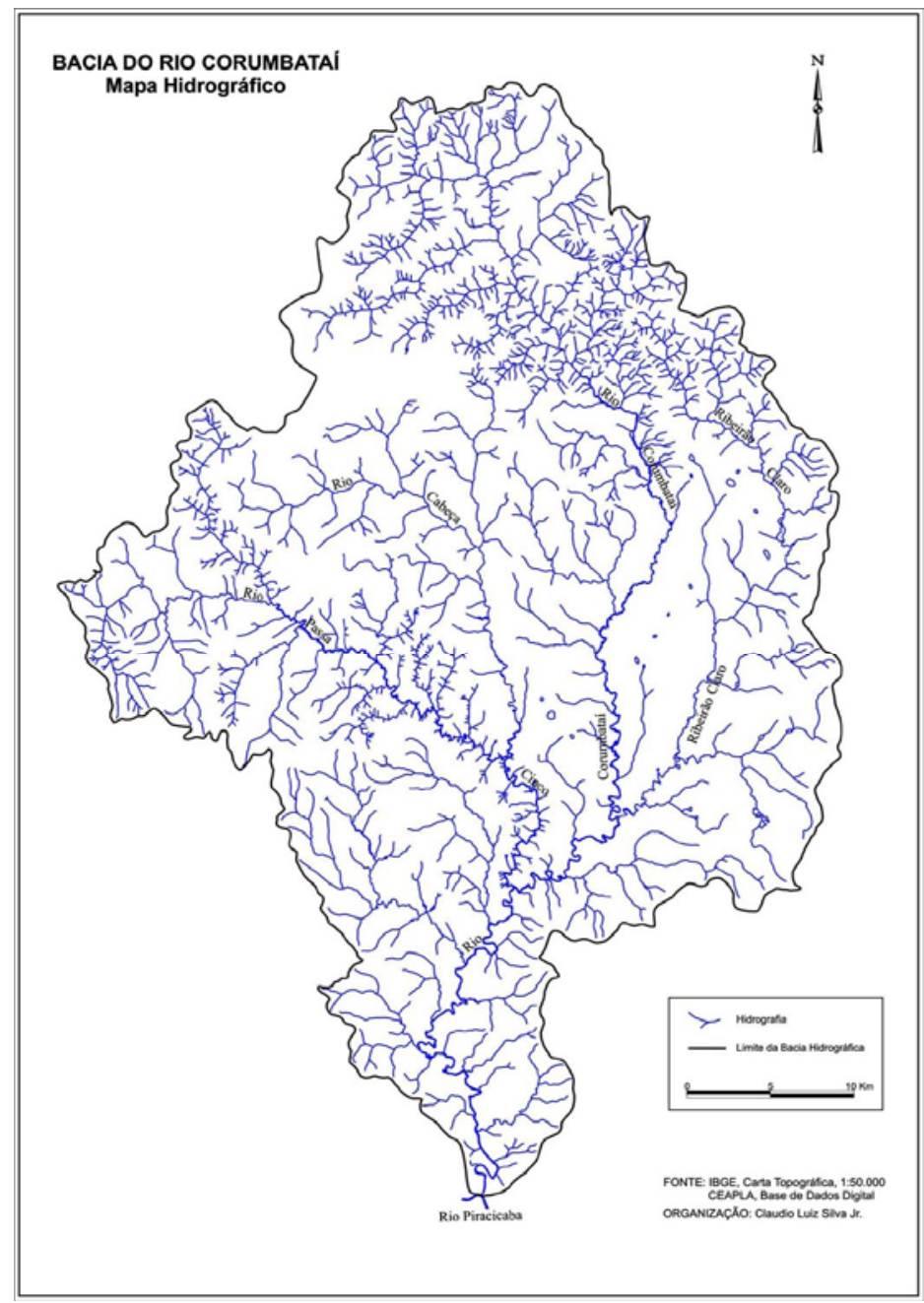

Figura 23 - Rede de drenagem da bacia hidrográfica do rio Corumbataí Fonte: UNESP/IGCE/CEAPLA (2004) 


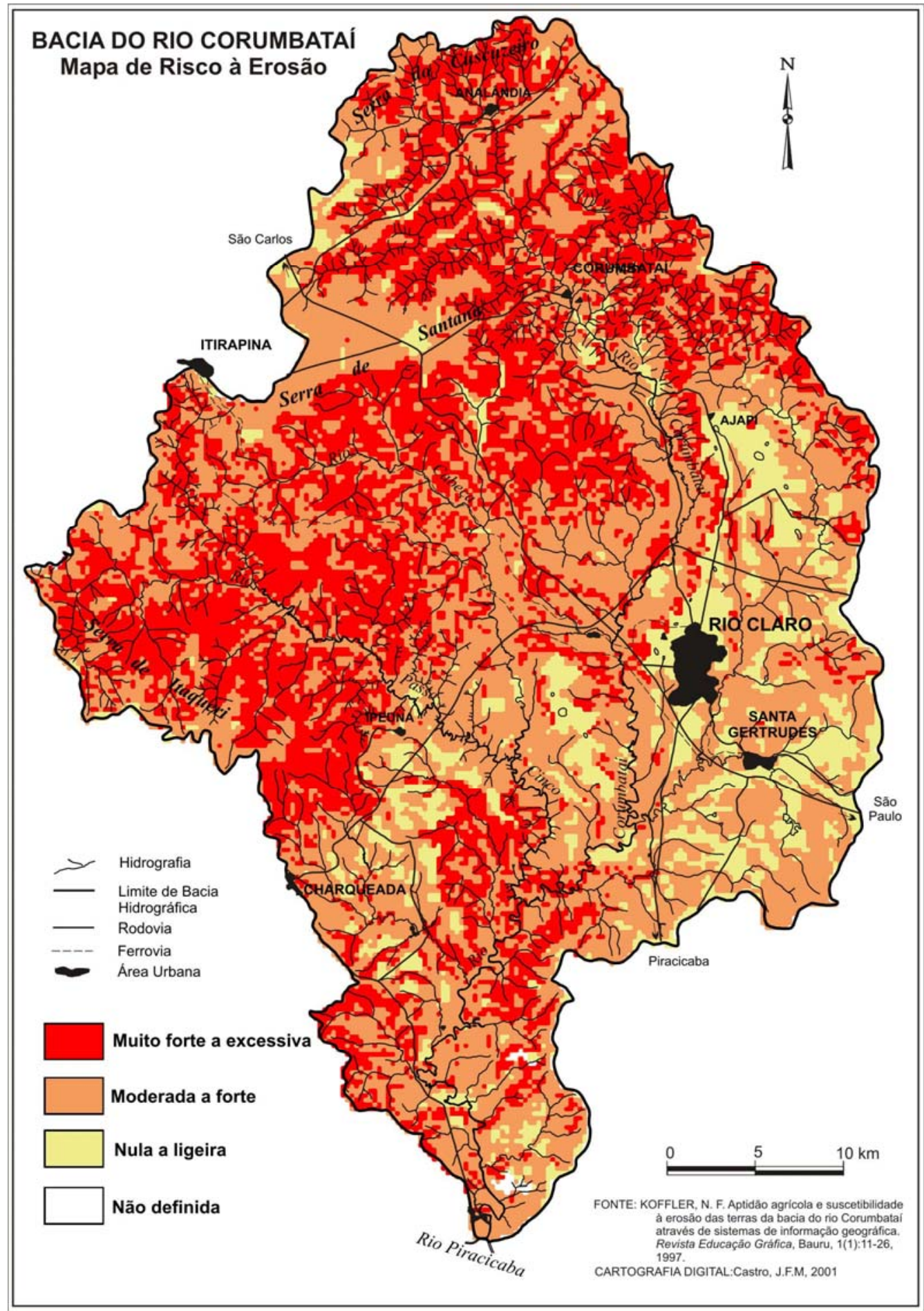

Figura 24-- Mapa de risco à erosão da bacia do rio Corumbataí Fonte: UNESP/IGCE/CEAPLA (2004) 


\subsubsection{Uso e ocupação do Solo}

\subsubsection{Bacia hidrográfica do rio Piracicaba}

As primeiras atividades agrícolas na região remontam ao século XVII, quando foram estabelecidos os povoamentos que serviam de apoio às bandeiras, que partiam rumo às minas de ouro do centro-oeste brasileiro. Praticava-se então, a agricultura de subsistência, sem nenhuma expressão maior (São Paulo, 1996). A agricultura de subsistência e o apoio às atividades mineradoras e de ação dos bandeirantes foram aos poucos substituídas pela cultura da cana-de-açúcar, que, de fato, viria a estabelecer os marcos constitutivos da região, pelo acréscimo populacional, estruturas de produção e comercialização e viabilização de conexões com outras áreas (CBH-PCJ, 2000).

O início da utilização do solo para fins de agricultura intensiva na bacia hidrográfica do rio Piracicaba data do final do século XIX, com a introdução da cultura do café, que teve grande desenvolvimento na região (São Paulo, 1996). Mesmo com a crise da economia cafeeira na década de 30, a região onde se insere a bacia pôde superar o problema pela introdução de novas culturas e desmembramento de propriedades (CBH-PCJ, 2000).

A bacia hidrográfica do rio Piracicaba é considerada uma das mais ricas regiões do país, com condições sócio-econômicas comparáveis às do primeiro mundo e que foram alcançadas devido à associação de vários fatores como fertilidade do solo, relevo, clima e localização, que atraíram os imigrantes europeus, responsáveis pela forte influência na colonização da região. Na década de 70, o governo iniciou um programa de incentivo à descentralização econômica nas grandes metrópoles, particularmente na Grande São Paulo. Novas empresas procuraram se instalar em regiões que dispunham de boa infra-estrutura viária, mão de obra qualificada e fossem próximas dos centros consumidores, provocando as empresas tradicionais a seguirem este exemplo. A região central da bacia preenchia esses requisitos e esse foi o ponto de partida para o seu desenvolvimento (Ferraz \& Caron, 2001).

As maiores transformações na região ocorreram nas décadas de 70 e 80,

quando as cidades tiveram acentuado desenvolvimento econômico, impulsionado 
principalmente pela atividade agro-industrial. Hoje, na bacia, concentram-se alguns dos principais centros urbanos do Estado. O alto grau de urbanização é um indicativo das sérias intervenções do homem no meio ambiente, tendo como conseqüência imediata, a deterioração dos recursos hídricos e o crescente aumento da demanda de água (Ferraz \& Caron, 2001).

Ferraz \& Caron (2001), analisando censos realizados pelo IBGE e pelo Instituto de Economia Agrícola, de 1960 a 1985, para a bacia do rio Piracicaba e para o município de Piracicaba, município típico da região central da bacia, concluíram, dentre outros fatos, que: a área total destinada às lavouras permanentes e temporárias cresceu 41,3\% na bacia, enquanto no município de Piracicaba decresceu $31 \%$ no mesmo período; a redução de pastagens naturais e plantadas foi vertiginosa no município, sendo alarmante a redução de matas naturais na bacia e no município de Piracicaba.

$\mathrm{Na}$ década de 80 , mesmo com a crise econômica vivida pelo país, o Estado de São Paulo foi favorecido pela política de crédito rural e manteve relativo dinamismo. Nesse período cresceram as culturas exportáveis, como a soja e a laranja e as energéticas como a cana, que recebeu subsídios e incentivos do PROÁLCOOL, não sofrendo os efeitos da crise (São Paulo, 1994).

Atualmente a agricultura na bacia é bastante diversificada, mas com predominâncias regionais. Da região central da bacia em direção a oeste, predomina a cultura da cana-de-açúcar. Na região central destaca-se a cultura de citrus e em direção a leste observa-se maior diversificação do uso do solo com predominância de pastagens (São Paulo, 1996; Ferraz, 2002).

A bacia do rio Piracicaba possui diversas áreas naturais protegidas por lei e medidas específicas, que ocupam parcelas significativas de seu espaço físico. As áreas protegidas por lei somam $5.063 \mathrm{Km}^{2}$, distribuídos por diversos municípios da bacia. Não estão aqui consideradas as áreas de preservação permanente, nem a destinação de $20 \%$ das áreas das propriedades rurais como reserva legal protegidas pelo Código Florestal (CBH-PCJ, 2000).

A bacia hidrográfica do rio Piracicaba possui $12.400 \mathrm{Km}^{2}$ de área, dos quais $11.600 \mathrm{Km}^{2}$ inseridos no Estado de São Paulo, portanto as áreas de proteção descritas contemplam cerca de $45 \%$ da área da bacia. Dos 46 municípios da bacia hidrográfica do rio Piracicaba, 15 deles possuem mais de $80 \%$ de sua área dentro de alguma unidade de conservação. É importante salientar que nem todas as áreas 
protegidas estão regulamentadas e conseqüentemente não são praticadas diversas restrições de uso nestas áreas (CBH-PCJ, 2000).

O Quadro 11 apresenta os dados sobre o uso do solo assumidos para o Plano de bacias 2000-2003 (CBH-PCJ, 2000).

A Figura 25 extraída do Projeto Piracena (2004) é o mapa para uso do solo em 1997.

As categorias utilizadas para definir o uso e ocupação do solo são diversificadas nos trabalhos consultados. No Projeto Piracena (2004) não havia tabela de valores disponível associada ao mapa oferecido pela fonte como informação. 


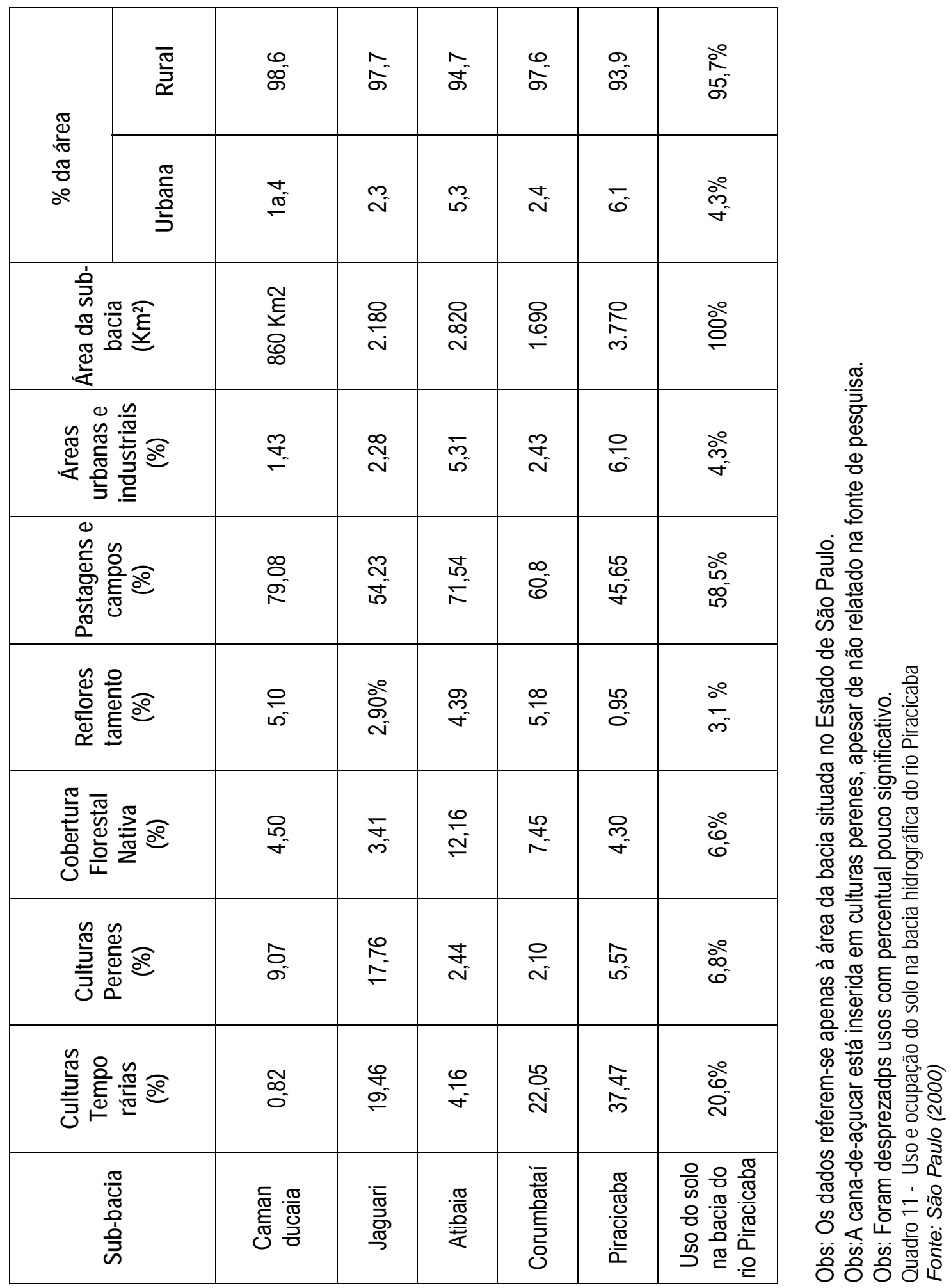




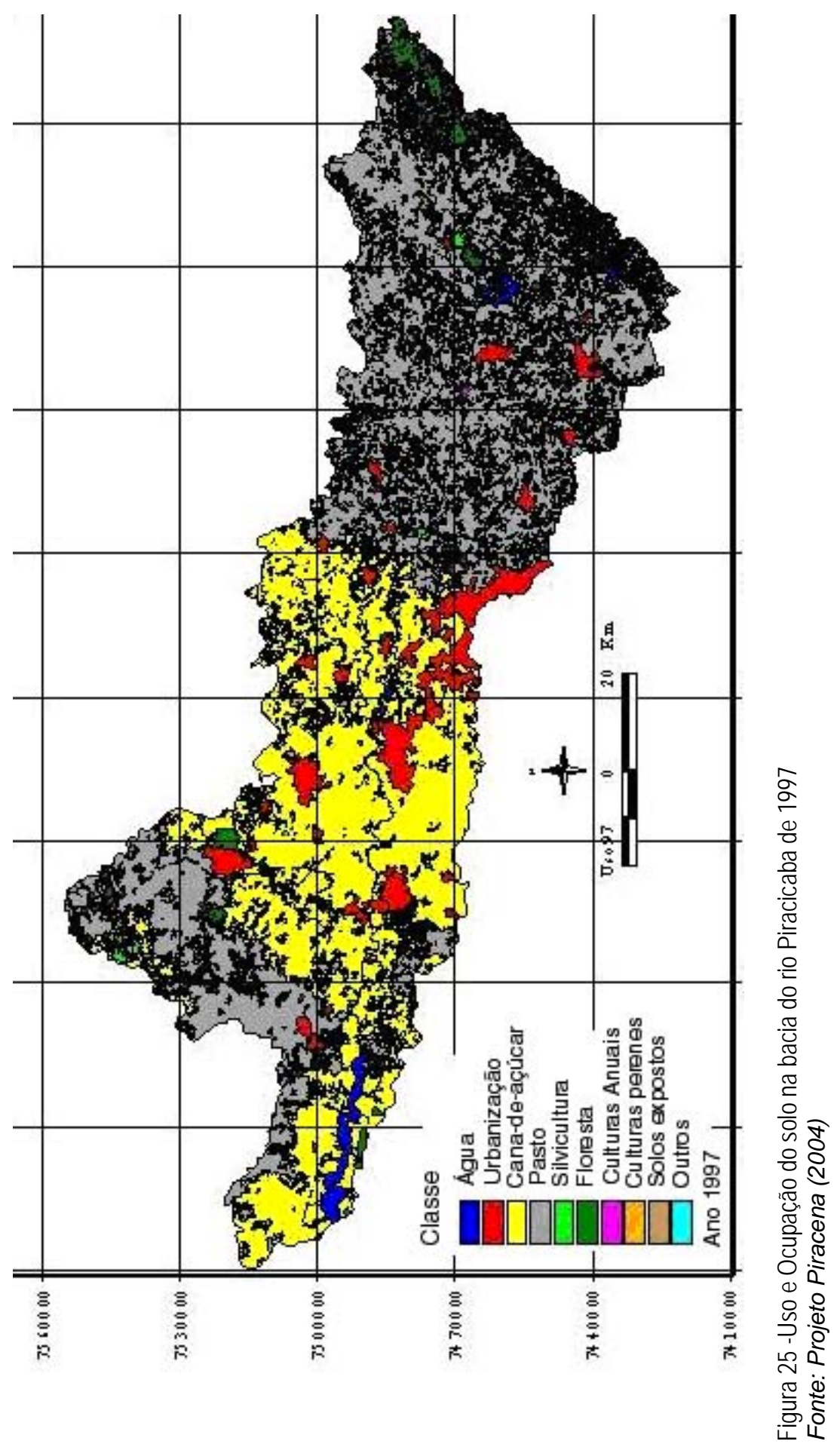




\subsubsection{Bacia hidrográfica do rio Corumbataí}

As primeiras noticias que se tem sobre essa região remontam aos princípios do século XVIII quando passavam forasteiros e viajantes que se embrenhavam rumo ao sertão desconhecido. No entanto, o povoamento e a ocupação só se efetivaram com a expansão das fazendas de criação de gado e o desenvolvimento de uma lavoura canavieira que passou a progredir, no final do século XVIII, Porém, o café foi o principal agente responsável pelo intenso povoamento e o progresso dessas terras. Também o café foi o responsável pela decadência econômica que atingiu a área no início do século $\mathrm{XX}$, prolongando-se por várias décadas.

O grande avanço na região foi dado pela introdução da cultura da cana, já nas primeiras décadas do século XIX.

Entre as décadas de 70 e 80, os municípios de Rio Claro e Piracicaba acompanharam a tendência da região e registraram crescimento em seus parques industriais (Garcia, 2004).

Segundo Garcia (2000), nos municípios de Analândia, Corumbataí, Ipeúna, Itirapina, Charqueada e Santa Gertrudes, a industrialização não é significativa. Na bacia, o desenvolvimento mais acentuado de atividades concentrase na extração de minerais, em decorrência das jazidas de calcários silicosos, argila e barro para as olarias. O autor não mencionou a atividade intensa de extração de areia, que ocorre principalmente no Alto e Médio Corumbataí. Em decorrência dessa exploração mineraria, a indústria de extração e transformação de minerais não-metálicos, principalmente cerâmicas, calcários e olarias, têm um papel tradicional na estrutura industrial. Hoje, o município de Santa Gertrudes forma com os municípios de Rio Claro, Cordeirópolis, Limeira e Araras, o maior pólo cerâmico do Estado de São Paulo e do país.

Nos municípios de Corumbataí, Itirapina, Ipeúna, Santa Gertrudes e Analândia, a agricultura atende à demanda local produzindo feijão, arroz, algodão e milho. A cana-de-açúcar destaca-se entre os produtos agrícolas, atendendo à demanda de usinas próximas à região. O desempenho agrícola dos municípios é 
fraco e a migração para a zona urbana é reflexo desse quadro (Garcia, 2004).

Segundo Fischer (2003), nas regiões noroeste e centro-oeste da bacia do rio Corumbataí há extensas áreas com alto risco de erosão. No Alto Corumbataí, o uso do solo predominante é a pastagem e as principais fontes de poluição são difusas. No médio Corumbataí estão concentradas as principais fontes de poluição industriais e urbanas da bacia. No Baixo Corumbataí predominam as atividades de extração de areia em leito de rio e a monocultura da cana-de-açúcar.

Conforme relatado por IPEF \& SEMAE (2001), a bacia do rio Corumbataí apresenta $43,68 \%$ de sua área ocupada por pastagens e $25,57 \%$ por cana-de-açúcar, sendo que a área de floresta nativa cobre somente 12,26\% da área total. O Quadro 12 especifica os usos do solo identificados pelo autor. A Figura 26 apresenta o mapa de Uso e cobertura do solo da bacia.

\begin{tabular}{|c|c|}
\hline Uso e cobertura do Solo & $\begin{array}{c}\text { Área } \\
\text { (\%) }\end{array}$ \\
\hline Cana-de-açúcar & 25,57 \\
\hline Pastagem & 43,68 \\
\hline Floresta plantada & 7,33 \\
\hline Floresta nativa & 12,36 \\
\hline Fruticultura & 2,82 \\
\hline Cultura anual & 1,02 \\
\hline Mineração & 0,09 \\
\hline Área urbana & 2,77 \\
\hline Outros & 4,37 \\
\hline TOTAL & 100 \\
\hline
\end{tabular}

Quadro 12 - Uso e cobertura do solo atual na bacia hidrográfica do rio Corumbataí Fonte: IPEF \& SEMAE (2001) 


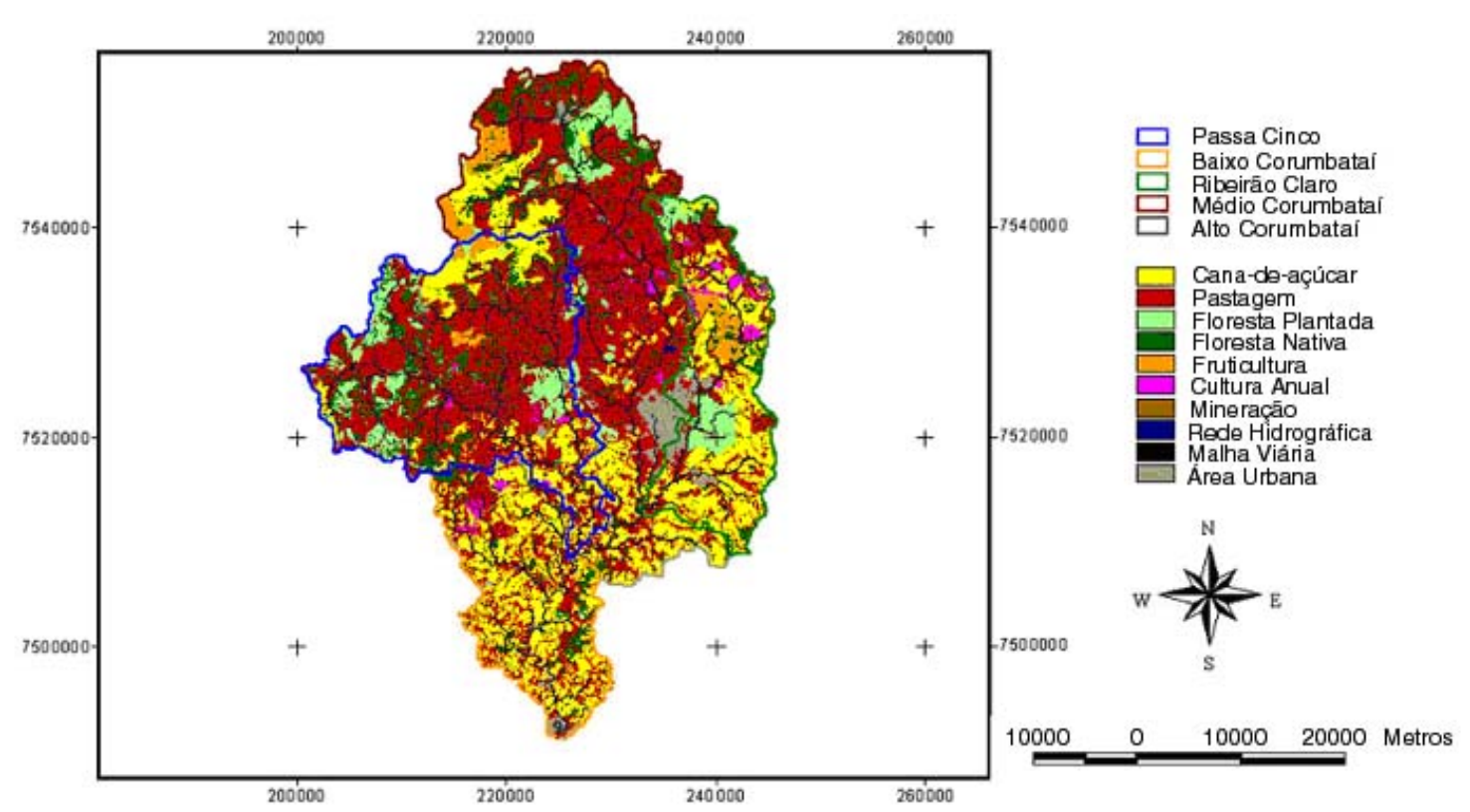

Figura 26- Uso e cobertura do solo atual na bacia do rio Corumbataí Fonte: IPEF \& SEMAE (2001)

\subsubsection{Disponibilidade hídrica das bacias}

\subsubsection{Bacia hidrográfica do rio Piracicaba}

A crescente demanda de água para uso urbano, agrícola e industrial acentua os problemas de escassez e qualidade dos recursos hídricos na bacia de drenagem do rio Piracicaba. A disponibilidade hídrica média da bacia é de $165 \mathrm{~m} / \mathrm{s}$ (São Paulo, 1990), sendo que as sub-bacias dos rios Jaguari e Camanducaia juntas contribuem com $63 \mathrm{~m}^{3} / \mathrm{s}$, a do Atibaia com $35 \mathrm{~m} 3 / \mathrm{s}$, a do rio Piracicaba com $45 \mathrm{~m}^{3} / \mathrm{s}$ e a do Corumbataí com $22 \mathrm{~m} 3 / \mathrm{s}$. Em períodos de estiagem severa, a disponibilidade hídrica média da bacia de drenagem do médio Piracicaba, para sete dias consecutivos e período de retorno de 10 anos $\left(Q_{7,10}\right)$, cai para $29,58 \mathrm{~m}^{3} / \mathrm{s}$, sendo que em $95 \%$ do tempo ( $\left.Q_{95 \%}\right)$, essa disponibilidade sobe para $44,27 \mathrm{~m}^{3} / \mathrm{s}$. A demanda de água reconhecida na bacia do rio Piracicaba é de $7,95 \mathrm{~m}^{3} / \mathrm{s}$, que somada ao uso conjuntivo de $3,05 \mathrm{~m}^{3} / \mathrm{s}$, soma $11,0 \mathrm{~m}^{3} / \mathrm{s}$. (CBH-PCJ, 2000). As demandas por tipo de uso do rio Piracicaba estão expostas no Quadro 130 uso 
consuntivo caracteriza-se por exemplo pela incorporação de água à produção de insumos. A caracterização dos usos consuntivos não foi apresentada pela fonte bibliográfica.

\begin{tabular}{|c|c|c|c|c|}
\hline \multirow{2}{*}{$\begin{array}{l}\text { Usos da sub-bacia } \\
\text { do rio Piracicaba }\end{array}$} & \multirow{2}{*}{ Demanda. (m3/s) } & \multirow{2}{*}{$\%$} & \multicolumn{2}{|c|}{ Disponibilidade hídrica } \\
\hline & & & $\begin{array}{l}\mathrm{Q} 7,10\left(\mathrm{~m}^{3} / \mathrm{s}\right) \\
\text { rio Piracicaba }\end{array}$ & $\begin{array}{c}\mathrm{Q} 95 \%\left(\mathrm{~m}^{3} / \mathrm{s}\right) \\
\text { rio Piracicaba }\end{array}$ \\
\hline Doméstico & 1,49 & 13,54 & & \\
\hline Industrial & 3,80 & 34,54 & & \\
\hline Irrigação e Aqüicultura & 2,66 & 24,18 & & \\
\hline Uso consuntivo & 3,05 & 27,72 & & \\
\hline TOTAL & 11,00 & $100 \%$ & 29,58 & 44,27 \\
\hline
\end{tabular}

Quadro 13 - Demanda e disponibilidade de água na sub- bacia do rio Piracicaba distribuída entre os diferentes usos para 0 ano 2000

Fonte: Adaptado de São Paulo (2000).

O Quadro 14 apresenta um quadro de vazões médias mensais máximas e mínimas para a bacia do rio Piracicaba e suas principais sub-bacias

\begin{tabular}{|c|c|c|c|c|c|}
\hline \multirow{2}{*}{ Sub-bacia } & Período & \multicolumn{2}{|c|}{ Média mensal das máximas } & \multicolumn{2}{c|}{ Média mensal das mínimas } \\
\cline { 2 - 6 } & & Mês & Vazão(m $\left.\mathbf{m}^{3} / \mathbf{s}\right)$ & Mês & Vazão(m $\mathbf{3} \mathbf{s})$ \\
\hline Camanducaia & 1943 a 1997 & março & 79,2 & setembro & 4,30 \\
\hline Jaguari & 1943 a 1997 & março & 181,0 & setembro & 19,6 \\
\hline Atibaia & 1936 a 1997 & março & 138,0 & setembro & 15,8 \\
\hline Corumbataí & 1989 a 1997 & março & 128,0 & outubro & 6,2 \\
\hline Piracicaba & 1931 a 1997 & março & 478,0 & setembro & 52,8 \\
\hline
\end{tabular}

Quadro 14 - Vazões médias máximas e mínimas mensais das sub-bacias da bacia do rio Piracicaba Fonte: Adaptado de São Paulo (2000).

A bacia hidrográfica do rio Piracicaba caracteriza-se por suas interações com outras bacias vizinhas, com exportação e importação de vazões de água. A bacia possui instalado em suas cabeceiras o Sistema Cantareira, responsável pelo abastecimento público de cerca de 50\% da população da Região 
Metropolitana de São Paulo (RMSP), ou seja, cerca de nove milhões de pessoas. O sistema possui vazão de exportação da bacia de $32 \mathrm{~m} 3 / \mathrm{s}$. Este sistema possui reservatórios de regularização de vazão nos rios Atibainha e Cachoeira, na subbacia do rio Atibaia e nos rios Jacareí/Jaguari, na sub-bacia do rio Jaguari. Esses reservatórios têm vazão controlada pela SABESP e ditada pelo Grupo Técnico de Monitoramento Hidrológico do Comitê de Bacias Hidrográficas dos rios Piracicaba/Capivari/Jundiaí. A vazão oficial de descarga para jusante das barragens é de $4 \mathrm{~m}^{3} / \mathrm{s}$, sendo $3 \mathrm{~m}^{3} / \mathrm{s}$ pelo rio Atibaia e $1 \mathrm{~m}^{3} / \mathrm{s}$ pelo Jaguari. A vazão média de descarga do Sistema Cantareira, assumida em documentos oficiais, é de $4 \mathrm{~m} 3 / \mathrm{s}$ (CBH-PCJ, 2000). Sabe-se no entanto, que nos últimos três anos, pelo menos, a vazão média oficial advinda do Sistema Cantareira não tem sido respeitada, diante da redução da capacidade operacional dos reservatórios do sistema. Sabe-se que em fevereiro dos últimos anos, 2001, 2002, 2003 e 2004, a capacidade de reservação do sistema tem atingido os níveis de 37,4 \%, 46,7 \%, 47,4 \% e 6,5 \% respectivamente. Em outubro de 2001, 2002 e 2003, essa capacidade de reservação do sistema era de $16,3 \%, 31,2 \%$ e $5,4 \%$ respectivamente (Viveiros, 2004).

O Sistema Cantareira, que teve o início de suas obras ocorrido na década de 60, está hoje dentre os principais motivos de conflito pelo uso da água na bacia hidrográfica do rio Piracicaba.

A bacia de drenagem do rio Piracicaba pode ser portanto segmentada em um compartimento a montante dos reservatórios do Sistema Cantareira, com $1.965 \mathrm{Km}^{2}$ e com outro de $10.635 \mathrm{Km}^{2}$ a jusante dos mesmos. A área de drenagem dos reservatórios representa 15,6 \% da área total da bacia do rio Piracicaba, evidenciando a influência que os reservatórios exercem no regime de vazão dos seus cursos d'água (CBH-PCJ, 2000).

Segundo São Paulo (2000), na UGRHI 05, onde se inclui a bacia do rio Piracicaba, como maior segmento da unidade de gerenciamento, atualmente 97\% da demanda de água para abastecimento urbano, provém de mananciais superficiais e apenas 3 \% de mananciais subterrâneos; no uso industrial, estes números são 93,5 \% e 3,5 \% respectivamente.

Com o intuito de observar os índices de utilização do recurso hídrico disponível, frente às demandas totais de consumo atuais e projetadas observadas 
na fonte de pesquisa, estes dados foram dispostos no Quadro 9. Observa-se que a bacia do Médio Piracicaba não foi destacada no levantamento dos dados. Foi destacada a informação que reflete o uso da água em toda a bacia hidrográfica, incluindo a bacia do rio Corumbataí. As considerações sobre a projeção de consumo da água podem ser obtidas no trabalho denominado Programa de Investimentos para aproveitamento dos recursos hídricos das bacias dos rios Piracicaba, Capivari e Jundiaí (BRASIL, 1999).

\begin{tabular}{|c|c|c|c|c|c|c|c|c|}
\hline & \multicolumn{9}{|c|}{ Demanda/Disponibilidade Hídrica (\%) } \\
\hline \multirow{2}{*}{ Sub-bacias } & \multicolumn{2}{|c|}{$\mathbf{2 0 0 0}$} & \multicolumn{2}{|c|}{2005} & \multicolumn{2}{c|}{$\mathbf{2 0 1 0}$} & \multicolumn{2}{c|}{2020} \\
\cline { 2 - 10 } & $\mathbf{Q} 7,10$ & $\mathbf{Q} 95 \%$ & $\mathrm{Q} 7,10$ & $\mathrm{Q} 95 \%$ & $\mathrm{Q} 7,10$ & $\mathrm{Q} 95 \%$ & $\mathrm{Q} 7,10$ & $\mathrm{Q} 95 \%$ \\
\hline Camanducaia & 24,5 & 16,5 & 26,9 & 18,1 & 29,1 & 19,5 & 30,4 & 20,4 \\
\hline Jaguari & 91,8 & 58,6 & 99,2 & 63,4 & 109,1 & 69,6 & 124,3 & 79,4 \\
\hline Atibaia & 139,5 & 106,0 & 148,3 & 112,7 & 156,1 & 118,7 & 172,5 & 131,1 \\
\hline Corumbataí & 76,7 & 45,6 & 82,0 & 48,8 & 87,2 & 51,9 & 92,7 & 55,2 \\
\hline $\begin{array}{c}\text { Bacia do } \\
\text { Piracicaba }\end{array}$ & 112,5 & 75,2 & 120,2 & 80,3 & 128,2 & 85,7 & 142,0 & 94,9 \\
\hline
\end{tabular}

Quadro 15 - Relações entre Demanda e Disponibilidade dos recursos hídricos nas sub-bacias da bacia hidrográfica do rio Piracicaba

Fonte: Adaptado de São Paulo (2000)

\subsubsection{Bacia hidrográfica do rio Corumbataí}

A vazão denominada $Q$ 7,10, que pode ser a vazão mínima considerada para que os processos ecológicos, que ocorrem no curso d'água, não sejam afetados, foi estimado no relatório zero do $\mathrm{PCJ}$, para o rio Corumbataí em $4,55 \mathrm{~m} 3 / \mathrm{s}$. Isto significa, portanto, que a demanda de água no rio Corumbataí não pode atingir vazões superiores à vazão $Q_{7,10}$. Da mesma fonte bibliográfica, temos para o rio Corumbataí a Q ${ }_{7,10} \operatorname{com} 4,55 \mathrm{~m}^{3} / \mathrm{s}$ e Q $95 \%$ com 7,65 m³/s.

O Quadro 16 traz a demanda de água para diferentes usos no rio Corumbataí. Pode-se observar, que a maior demanda é para o uso doméstico (60,2\% da demanda), seguida pela irrigação $(19,9 \%)$, indústria $(16,4 \%)$, aqüicultura $(1,86 \%)$, mineração $(1,32 \%)$ e pecuária $(0,27)$. 


\begin{tabular}{|c|c|c|}
\hline Usos & Demanda. $\left(\mathbf{m}^{3} / \mathbf{s}\right)$ & $\%$ \\
\hline Doméstico & 2,424 & 60.19 \\
\hline Industrial & 0,662 & 16.44 \\
\hline Irrigação & 0,802 & 19.92 \\
\hline Aqüicultura & 0,075 & 1.86 \\
\hline Pecuária & 0,011 & 0.27 \\
\hline Mineração & 0,053 & 1.32 \\
\hline TOTAL & 4,0270 & 100.00 \\
\hline
\end{tabular}

Quadro 16 - Demanda de água na bacia do rio Corumbataí distribuída entre os diferentes usos Fonte: Adaptado de São Paulo(2000).

Com a demanda conhecida de 4,027 m3/s e com uma "vazão mínima ecológica", representada pelo Q 7,10, estimada em 4,55 m3/s, pode-se observar que a relação entre ambas é de $88 \%$, ou seja, a demanda hoje conhecida para a captação no Rio Corumbataí equivale a 88 \% da vazão mínima estabelecida.

\subsubsection{Demografia : bacias dos rios Piracicaba e Corumbataí}

Os 58 municípios da UGRHI PCJ somam uma população de 4,22 milhões de habitantes, dos quais 3,97 milhões (94,2 \%) residem em áreas urbanas e apenas 250.000(5,8 \%) em áreas rurais. Na parte da bacia que pertence ao estado de Minas Gerais, onde se localizam as cabeceiras dos rios Jaguari e Camanducaia, estão situados os municípios de Camanducaia, Extrema, Itapeva e Toledo, que juntos, perfazem uma população de 50.000 habitantes, dos quais $60 \%$ residem em área urbana.

As maiores transformações na região ocorreram nas décadas de 70 e 80, quando as cidades tiveram acentuado desenvolvimento econômico, impulsionado principalmente pela atividade agro-industrial (Ferraz e Caron, 2001).

$\mathrm{Na}$ década de 70 , as projeções apontavam para um crescimento populacional de tal ordem que se justificava falar em explosão demográfica. A população paulista cresceu a taxas médias de 3,5 \% ao ano. Já a Região 
Administrativa de Campinas e a bacia hidrográfica do rio Piracicaba apresentaram taxas superiores a 4,4 \% ao ano e 5,1 \% ao ano, respectivamente. O crescimento populacional médio da bacia do rio Piracicaba na década de 80 foi de $6,6 \%$ ao ano, superior à média brasileira de $2,4 \%$, no mesmo período. A economia da região tornou-se das mais dinâmicas, fornecendo $7 \%$ da receita bruta, $10 \%$ dos postos de trabalho e $9 \%$ dos estabelecimentos comerciais do Estado de São Paulo. Na parte central da bacia, os índices de crescimento foram muito maiores e as cidades multiplicaram várias vezes sua população em poucos anos, como é o caso de Americana, Nova Odessa, Sumaré, Paulínia, Campinas e Piracicaba (Ferraz e Caron, 2001).

Embora atualmente o ritmo de crescimento seja inferior às décadas de 70/80, a tendência do processo de conurbação é irreversível (Ferraz e Caron, 2001).

De forma geral, o ritmo de crescimento da população paulista vem diminuindo. Essa diminuição é devida particularmente à redução dos fluxos migratórios interestaduais. De uma participação de $42,4 \%$ no crescimento populacional do Estado, no período de 1970/80, o saldo migratório passou a responder por apenas 9\%, no período 1980/91 (CBH-PCJ, 2000).

De acordo com São Paulo (2000), as taxas geométricas de crescimento previstas para as populações urbanas da UGRHI 05 PCJ são decrescentes, passando de 2,09 \% no período de 2000/2005, para 1,19\% no período de 2015/2020. Mesmo assim, são superiores às esperadas para o Estado de São Paulo, de 0,97 \% e 0,73 \% para os mesmos períodos. O grau de urbanização da população será crescente, passando de 93,2 \% em 1996, para 96,8 \% em 2020. A população urbana da UGRHI 05 PCJ em 1996 correspondia a 11,4 \% da população urbana estadual, no ano 2020 deverá corresponder a 15,4 \%. Na bacia do rio Piracicaba merecem destaque por suas populações as cidades de Piracicaba, Limeira, Rio Claro e Bragança Paulista.

O Quadro 17 mostra a evolução projetada para as populações das bacias dos rios Piracicaba, Atibaia, Corumbataí, Camanducaia, Jaguari, de 1996 a 2020 (CBH-PCJ, 2000). 


\begin{tabular}{|c|c|c|c|c|c|c|}
\hline \multirow{2}{*}{ Sub-Bacias } & \multicolumn{2}{|c|}{1996 (IBGE) } & \multicolumn{2}{c|}{2005} & \multicolumn{2}{c|}{2020} \\
\cline { 2 - 7 } & Total & Urbana & Total & Urbana & Total & Urbana \\
\hline Atibaia $^{1}$ & 816.305 & 757.757 & 945.675 & 899.272 & 1.145 .506 & 1.113 .799 \\
\hline Corumbataí $^{23}$ & 217.060 & 205.565 & 261.656 & 252.849 & 321.687 & 316.443 \\
\hline Camanducaia $^{4}$ & 76.019 & 55.812 & 88.948 & 69.161 & 103.826 & 87.212 \\
\hline Jaguari4 $^{4}$ & 285.086 & 242.819 & 347.286 & 313.519 & 432.113 & 404.257 \\
\hline Piracicaba $^{123}$ & 1.324523 & 1.254 .493 & 1.610 .628 & 1.542 .006 & 2.066 .925 & 1.998 .935 \\
\hline $\begin{array}{c}\text { Total da Bacia do } \\
\text { Piracicaba }\end{array}$ & 2.718 .993 & 2.516 .446 & 3.254 .193 & 3.076 .807 & 4.070 .057 & 3.920 .646 \\
\hline $\begin{array}{c}\text { Grau de urbanização bacia } \\
\text { rio Piracicaba }\end{array}$ & \multicolumn{2}{|c|}{$92,6 \%$} & \multicolumn{2}{c|}{$94,5 \%$} & & $96,3 \%$ \\
\hline $\begin{array}{c}\text { Grau de urbanização bacia } \\
\text { rio Corumbataí }\end{array}$ & \multicolumn{2}{|c|}{$94,7 \%$} & \multicolumn{2}{c|}{$96,6 \%$} & \multicolumn{2}{c|}{$98,4 \%$} \\
\hline
\end{tabular}

Campinas: 48 \% da população situa-se na sub-bacia do Atibaia, 9 \% na sub-bacia do Piracicaba e 43 \% na bacia do Capivari, não descrita neste Quadro.

Charqueada: $70 \%$ na sub-bacia do Corumbataí e $30 \%$ na sub-bacia do médio Piracicaba

Piracicaba: $90 \%$ na sub-bacia Piracicaba e $10 \%$ na sub-bacia Corumbataí.

Santo Antonio da Posse: 70 \% na sub-bacia do Jaguari e 30\% na sub-bacia do Camanducaia

Quadro 17 - Populações das bacias dos rios Piracicaba, Atibaia, Corumbataí, Camanducaia, Jaguari, de 1996 a 2020

Fonte: Adaptado de São Paulo (2000)

Com a finalidade de investigar a evolução do comportamento do crescimento populacional dos municípios das bacias dos rios Piracicaba e Corumbataí, foram levantados dados dos censos demográficos do IBGE, através de SEADE (2003). Dentre os dados levantados junto ao SEADE (2003), as taxas de crescimento da população total, de 1980/1991, 1991/2000 e 2000/2002, foram as principais informações utilizadas para análise do comportamento médio de cada unidade de estudo.

Os municípios pesquisados das bacias hidrográficas dos rios Piracicaba e Corumbataí, pertencentes à UGRHI PCJ 05, estão listados nos Quadros 18 e 19, com suas respectivas populações e taxas de crescimento para os três períodos analisados, obtidas pelo Censo do IBGE de 2000, sem enquadramento por faixas populacionais de municípios. Estão ainda listadas as taxas de crescimento da população total para a Região Administrativa de Campinas e para o Estado de São Paulo. 


\begin{tabular}{|c|c|c|c|c|}
\hline & Bacia do rio Piracicaba & \multirow{2}{*}{$\begin{array}{l}\text { Taxa anual de } \\
\text { crescim/geom \% } \\
\text { a.a } 80 / 91\end{array}$} & \multirow{2}{*}{$\begin{array}{c}\text { Taxa anual de } \\
\text { crescim/geom } \% \\
\text { a.a } 91 / 00\end{array}$} & \multirow{2}{*}{$\begin{array}{c}\text { Taxa anual de } \\
\text { crescim/geom \% } \\
\text { a.a 00/02 }\end{array}$} \\
\hline & CIDADE & & & \\
\hline 1 & Águas de São Pedro & 4,07 & 1,24 & 0,79 \\
\hline 2 & Americana & 2,13 & 1,95 & 1,51 \\
\hline 3 & Amparo & 1,80 & 2,00 & 1,67 \\
\hline 4 & Artur Nogueira & 5,27 & 5,95 & 3,66 \\
\hline 5 & Atibaia & 3,70 & 2,92 & 2,70 \\
\hline 6 & Bom Jesus dos Perdões & 3,01 & 3,45 & 2,78 \\
\hline 7 & Bragança Paulista & 2,36 & 2,58 & 2,29 \\
\hline 8 & Campinas & 2,22 & 1,54 & 1,24 \\
\hline 9 & Cordeirópolis & 3,24 & 3,15 & 3,00 \\
\hline 10 & Cosmópolis & 4,24 & 2,87 & 2,62 \\
\hline 11 & Holambra &. & 2,74 & 2,55 \\
\hline 12 & Hortolândia & & 6,73 & 3,94 \\
\hline 13 & Iracemápolis & 3,39 & 3,01 & 2,29 \\
\hline 14 & Itatiba & 3,62 & 3,15 & 2,76 \\
\hline 15 & Jaguariúna & 4,62 & 2,64 & 2,23 \\
\hline 16 & Jarinu & 5,24 & 5,15 & 4,05 \\
\hline 17 & Joanópolis & 0,50 & 2,69 & 2,38 \\
\hline 18 & Limeira & 2,96 & 2,09 & 1,79 \\
\hline 19 & Monte Alegre do Sul & 1,01 & 1,70 & 1,34 \\
\hline 20 & Monte Mor & 5,59 & 4,38 & 3,50 \\
\hline 21 & Morungaba & 2,10 & 2,14 & 1,82 \\
\hline 22 & Nazaré Paulista & 3,00 & 2,42 & 2,04 \\
\hline 23 & Nova Odessa & 4,11 & 2,41 & 1,68 \\
\hline 24 & Paulínia & 5,29 & 3,89 & 3,54 \\
\hline 25 & Pedra Bela & 0,84 & 0,97 & 1,12 \\
\hline 26 & Pedreira & 2,40 & 2,70 & 2,22 \\
\hline 27 & Pinhalzinho & 2,50 & 3,05 & 2,59 \\
\hline 28 & Piracaia & 3,03 & 2,29 & 1,89 \\
\hline 29 & Piracicaba & 2,58 & 1,90 & 1,65 \\
\hline 30 & Rio das Pedras & 3,21 & 2,38 & 1,92 \\
\hline 31 & Saltinho & . & 1,42 & 1,45 \\
\hline
\end{tabular}

Quadro 18 - Taxas de crescimento da população total dos municípios da bacia do rio

Piracicaba da UGRHI - PCJ - 05

Fonte: SEADE (2003) 


\begin{tabular}{|l|c|c|c|c|}
\hline 32 & $\begin{array}{c}\text { Santa Bárbara } \\
\text { d'Oeste }\end{array}$ & 5,99 & 1,85 & 1,41 \\
\hline 33 & Santa Maria da Serra & 3,88 & 1,00 & 0,88 \\
\hline 34 & $\begin{array}{c}\text { Santo Antônio da } \\
\text { Posse }\end{array}$ & 2,54 & 3,35 & 2,63 \\
\hline 35 & São Pedro & 3,89 & 3,78 & 3,27 \\
\hline 36 & Sumaré & 7,53 & 3,88 & 2,41 \\
\hline 37 & Tuiuti &. & 2,16 & 1,91 \\
\hline 38 & Valinhos & 3,02 & 2,29 & 1,71 \\
\hline 39 & Vargem &. & 3,86 & 3,46 \\
\hline 40 & Vinhedo & 4,07 & 3,90 & 3,56 \\
\hline & $\begin{array}{c}\text { Média da Bacia do rio } \\
\text { Piracicaba }\end{array}$ & 3,40 & 2,84 & 2,31 \\
\hline
\end{tabular}

Quadro 18 - Taxas de crescimento da população total dos municípios da bacia do rio Piracicaba da UGRHI - PCJ 05

Fonte: SEADE (2003)

\begin{tabular}{|c|c|c|c|}
\hline $\begin{array}{c}\text { Bacia do rio } \\
\text { Corumbataí }\end{array}$ & $\begin{array}{c}\text { Taxa anual de } \\
\text { crescim/geom } \\
\text { \% a.a } \\
\mathbf{8 0 / 9 1}\end{array}$ & $\begin{array}{c}\text { Taxa anual de } \\
\text { crescim/geom } \\
\text { \%a.a } \\
\mathbf{9 1 / 0 0}\end{array}$ & $\begin{array}{c}\text { Taxa anual de } \\
\text { crescim/geom } \\
\text { \%a.a } \\
\mathbf{0 0 / 0 2}\end{array}$ \\
\hline CIDADE & 2,50 & 1,94 & 1,87 \\
\hline Analândia & 1,72 & 2,19 & 1,79 \\
\hline Charqueada & 1,10 & 2,08 & 1,97 \\
\hline Corumbataí & 3,50 & 5,43 & 4,22 \\
\hline Ipeúna & 2,03 & 2,28 & 1,97 \\
\hline Rio Claro & 2,51 & 4,74 & 3,78 \\
\hline Santa Gertrudes & 2,58 & 1,90 & 1,65 \\
\hline Piracicaba & 2,28 & 2,94 & 2,46 \\
\hline $\begin{array}{c}\text { Média da bacia do Corumbataí } \\
\text { com o município de Piracicaba }\end{array}$ & 2,33 & 3,23 & 2,68 \\
\hline $\begin{array}{c}\text { Média da bacia do Corumbataí } \\
\text { sem o município de Piracicaba }\end{array}$ & 2,91 & 2,31 & 1,91 \\
\hline Região Adm. De Campinas & 2,12 & 1,82 & 1,54 \\
\hline Estado de São Paulo & \multicolumn{2}{|c}{} \\
\hline
\end{tabular}

Quadro 19 - Taxas de crescimento da população total dos municípios da bacia do rio Corumbataí da UGRHI - PCJ - 05 e taxas de referência regionais

Fonte: SEADE (2003) 


\subsubsection{Caracterização Econômica: bacias dos rios Piracicaba e Corumbataí}

A caracterização econômica dos municípios foi realizada a partir do índice fiscal intitulado Valor Adicionado Total. Esta grandeza engloba os Valores Adicionados Fiscais dos segmentos indústria, agropecuária, prestação de serviços e outros. Este índice caracteriza a participação do município, para o segmento analisado, na riqueza do Estado de São Paulo.

Os dados foram obtidos para os anos de 1993 a 2002, junto à Fundação SEADE (www. seade.gov.br). Os valores monetários foram atualizados pelo Índice Geral de Preços - Disponibilidade Interna - IGP - DI, da Fundação Getúlio Vargas - FGV.

A definição de Valor Adicionado utilizada neste trabalho é a que segue:

\footnotetext{
"Valor das saídas de mercadorias, acrescido do valor das prestações de serviços no seu território, deduzido o valor das entradas de mercadorias, em cada ano civil, das atividades econômicas. O Valor Adicionado é utilizado, pela Secretaria da Fazenda, como um dos critérios para a definição do Índice de Participação dos municípios no produto da arrecadação do ICMS (SEADE, 2003)."
}

\subsubsection{Instrumentos de Planejamento Municipal: bacias dos rios Piracicaba e Corumbataí}

O desenvolvimento de regiões pode ser incentivado também pelo favorecimento de municípios à implantação de empreendimentos, através de recursos como isenção de taxas e doação de terrenos. A ausência de Planos Diretores municipais pode significar maior desorganização do município quanto ao uso de suas áreas, levando, por exemplo, à ocupação de áreas ambientalmente frágeis.

$\mathrm{Na}$ busca de obter um retrato para a qualificação e intenção dos 
municípios das unidades de estudo, foram organizadas informações sobre os municípios das duas unidades de estudo referentes a:

- Incentivos para a implantação de empreendimentos através da isenção de taxas,

- Incentivos para a implantação de empreendimentos através da doação de terrenos

- Existência de Lei de Plano Diretor Municipal.

- $\quad$ Os dados foram obtidos para o ano de 1997, junto ao SEADE (2003).

\subsubsection{Qualidade de Vida: bacias dos rios Piracicaba e Corumbataí}

A sustentabilidade dos recursos naturais é perseguida atualmente por diversos segmentos da sociedade, pelo menos como conceito. Como alcançar ou medir a sustentabilidade. no uso dos recursos naturais, na ocupação da terra, na interferência do homem no meio, não é tarefa fácil.

As elevadas taxas de crescimento econômico e populacional das últimas décadas, registradas para a bacia do rio Piracicaba e descritas em diversos trabalhos, foram definitivas para interferir negativamente sobre a qualidade das águas de seus recursos hídricos. Pode-se inferir que a sustentabilidade na bacia do rio Piracicaba não vem sendo alcançada.

Considerando-se a ausência de índices que reflitam o uso adequado dos recursos naturais em uma bacia hidrográfica, além dos índices que medem a qualidade das águas dos rios, optou-se por utilizar um índice estabelecido para medir o nível de desenvolvimento humano, o IDH-M, o Índice de Desenvolvimento Humano Municipal e outro estabelecido pelo Governo do Estado de São Paulo, denominado IPRS, Índice Paulista de Responsabilidade Social. Essa escolha foi feita com o objetivo de investigar se estes índices poderiam oferecer algum indicativo que relacionasse a qualidade de vida da população com a qualidade do meio.

\subsubsection{1 Índice de Desenvolvimento Humano Municipal - IDH-M}


O Índice de Desenvolvimento Humano foi criado pela ONU, Organização das Nações Unidas, originalmente para medir o nível de desenvolvimento humano dos países a partir de indicadores de educação (alfabetização e taxa de matrícula), longevidade (esperança de vida ao nascer) e renda (PIB per capita). O índice varia de 0 (nenhum desenvolvimento humano) a 1 (desenvolvimento humano total). Países com IDH até $\underline{0,499}$ têm desenvolvimento

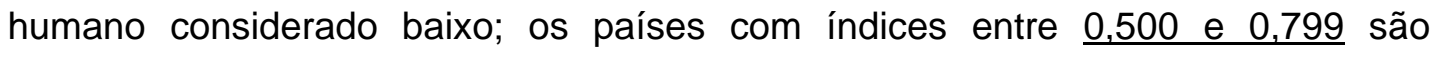
considerados de médio desenvolvimento humano; países com IDH maior que 0,800 têm desenvolvimento humano considerado alto (PNUD, 2004).

Para aferir o nível de desenvolvimento humano de municípios as dimensões são as mesmas - educação, longevidade e renda, mas alguns dos indicadores usados são diferentes. Embora meçam os mesmos fenômenos, os indicadores levados em conta no IDH municipal (IDHM) são mais adequados para avaliar as condições de núcleos sociais menores (PNUD, 2004).

Para a avaliação da dimensão educação, o cálculo do IDH municipal considera dois indicadores, com pesos diferentes: taxa de alfabetização de pessoas acima de 15 anos de idade (com peso dois) e a taxa bruta de freqüência à escola (com peso um). Para a avaliação da dimensão longevidade, o IDH municipal considera o mesmo indicador do IDH de países: a esperança de vida ao nascer. Esse indicador mostra o número médio de anos que uma pessoa nascida naquela localidade no ano de referência deve viver. O indicador de longevidade sintetiza as condições de saúde e salubridade daquele local, uma vez que quanto mais mortes houver nas faixas etárias mais precoces, menor será a expectativa de vida observada no local. Para a avaliação da dimensão renda, o critério usado é a renda municipal per capita, ou seja, a renda média de cada residente no município.

\subsubsection{2 Índice Paulista de Responsabilidade Social IPRS}

Segundo a Fundação Prefeito Faria Lima - Centro de estudos e pesquisas da administração municipal (Fundação Prefeito Faria Lima, 2004), o Estado de São Paulo possui um índice denominado IPRS, Índice Paulista de Responsabilidade Social, instituído por Lei no 10.765 em 19.02.2001). Ele é fruto 
das discussões do Fórum São Paulo Século XXI e foi elaborado pela Fundação SEADE. O IPRS busca caracterizar os municípios paulistas diante da riqueza, longevidade e escolaridade, ordenando os 645 municípios paulistas em cinco grupos classificatórios, quais sejam:

- Grupo 1 - município pólo

- Grupo 2 - economicamente dinâmico de baixo desenvolvimento social

- Grupo 3 - saudável e de baixo desenvolvimento econômico

- Grupo 4 - de baixo desenvolvimento econômico e em transição social

- Grupo 5 - de baixo desenvolvimento econômico e social

Segundo Beting (2001), os 645 municípios paulistas foram reunidos em cinco grupos. O primeiro, os municípios-pólo, são os privilegiados: apresentam indicadores de riqueza, escolaridade e longevidade acima da média do Estado. Curiosamente, eles se distribuem ao longo das principais rodovias - Presidente Dutra e Anhanguera. O grupo 1 é composto basicamente por cidades de grande porte como São Paulo, Campinas, São Bernardo do Campo. São apenas 84 localidades. Mas onde moram 21 milhões de pessoas, pouco mais de $60 \%$ da população do Estado. O grupo 2 pode ser considerado o vilão da história. São 50 municípios economicamente privilegiados. Mas onde a riqueza está nas mãos de poucos dos seus 4,8 milhões de habitantes e onde a escolaridade e a expectativa de vida deixam muito a desejar. No grupo 3 estão os municípios saudáveis. São 254 cidades consideradas pobres, mas que conseguem ter índices de escolaridade próximos à média estadual e alta expectativa de vida. Neles moram 3,8 milhões de pessoas. No grupo 4 foram reunidos os 163 municípios que estão em transição: pobres, mas que conseguiram avanços significativos no campo social, especialmente quanto à longevidade. O grupo 5 reúne 94 municípios e 1,7 milhão de habitantes onde à pobreza municipal somam-se baixos índices de escolaridade e longevidade. São localidades situadas nos bolsões de miséria do Vale do Ribeira e das serras do Mar e da Mantiqueira.

O IPRS vem sendo considerado um instrumento importante para o planejamento de políticas públicas dos municípios e para dar visibilidade à sociedade civil à gestão pública. 


\subsubsection{Qualidade das águas das bacias dos rios Piracicaba e Corumbataí}

Os atuais conflitos de uso dos recursos hídricos na UGRHI 05 PCJ são provocados pela degradação da qualidade das águas, decorrentes principalmente de lançamentos de cargas poluidoras originárias de esgotos urbanos e industriais. Além dessas fontes principais, outras devem ser consideradas, como as cargas difusas urbanas, rurais e industriais ( $\mathrm{CBH}-\mathrm{PCJ}$, 2000).

Os principais cursos d'água das sub-bacias e bacias que compõem a UGRHI 05 PCJ estão oficialmente enquadrados da seguinte forma: classe 1 trechos a montante das barragens do Sistema Cantareira; classe 2 - demais trechos não enquadrados nas classes 1, 3 e 4; classe 4 - rio Jundiaí, desde a área urbana de Jundiaí até sua foz. No entanto, longos trechos desses cursos d'água apresentam elevado grau de degradação, decorrente principalmente do lançamento de esgotos urbanos e industriais, alterando significativamente essa classificação. Segundo o Decreto 8468/76, os rios do Estado de São Paulo são classificados como:

- Classe 1: águas destinadas ao abastecimento doméstico, sem tratamento prévio ou com simples desinfecção;

- Classe 2: águas destinadas ao abastecimento doméstico, após tratamento convencional, à irrigação de hortaliças ou plantas frutíferas e à recreação de contato primário (natação, esqui-aquático e mergulho);

- Classe 3: águas destinadas ao abastecimento doméstico, após tratamento convencional, à preservação de peixes em geral e de outros elementos da fauna e da flora e à dessedentação de animais;

- Classe 4: águas destinadas ao abastecimento doméstico, após tratamento avançado, ou à navegação, à harmonia paisagística, ao abastecimento industrial, à irrigação e a usos menos exigentes.

As cargas orgânicas potenciais e remanescentes advindas de esgotos urbanos das bacias dos rios Piracicaba e Corumbataí estão expostas no Quadro 20. Os dados são atribuídos à bacia do rio Piracicaba, considerando todas as sub-bacias, Atibaia, Jaguari, Camanducaia, Corumbataí e Piracicaba e às duas 
unidades de estudo separadamente.

As cargas orgânicas industriais, potenciais e remanescentes estão expostas no Quadro 21, com a mesma estrutura do Quadro anterior.

\begin{tabular}{|c|c|c|c|c|c|c|}
\hline \multirow{2}{*}{ Sub-Bacia } & \multirow{2}{*}{$\begin{array}{c}\text { População } \\
\text { Urbana } \\
\text { (hab) }\end{array}$} & \multicolumn{2}{|c|}{ \% Atendimento } & \multicolumn{3}{|c|}{ Carga poluidora (t DBO/dia) } \\
\cline { 3 - 7 } & Coleta & Tratamento & Potencial & Remanescente & $\begin{array}{c}\% \\
\text { Removida }\end{array}$ \\
\hline Rio Corumbataí & 205.310 & 98 & 5 & 11.087 & 10.180 & 8,2 \\
\hline Rio Piracicaba & 1.251 .700 & 88 & 26 & 67.592 & 50.268 & 25,6 \\
\hline $\begin{array}{c}\text { Bacia do } \\
\text { Piracicaba } \\
\text { (todas as sub- } \\
\text { bacias) }\end{array}$ & 2.514 .530 & 87 & 15 & 132.776 & 114.835 & 13,5 \\
\hline
\end{tabular}

Quadro 20 - Cargas orgânicas poluidoras provenientes de esgotos domésticos geradas nas bacias indicadas Fonte: Adaptado de São Paulo (2000)

\begin{tabular}{|c|c|c|c|c|c|c|}
\hline Sub-Bacia & \multicolumn{2}{|c|}{ Carga Orgânica* } & \multicolumn{2}{c|}{ Sucro-Alcooleira* } & \multicolumn{2}{c|}{ Carga Inorgânica* $^{*}$} \\
\hline & Potencial & Remanescente & Potencial & Remanescente & Potencial & Remanescente \\
\hline Corumbataí & 27,3 & 4,3 & - & - & & - \\
\hline Piracicaba & 414,9 & 33,8 & 625,9 & 0,08 & 0,02 & - \\
\hline $\begin{array}{c}\text { Bacia do } \\
\begin{array}{c}\text { Piracicaba } \\
\text { (todas as } \\
\text { sub-bacias) }\end{array}\end{array}$ & 526,9 & 48,4 & 710,7 & 0,08 & 2,14 & 0,67 \\
\hline \multicolumn{7}{|c|}{${ }^{*}$ Cargas em t DBO/dia } \\
\hline
\end{tabular}

Quadro 21 - Cargas poluidoras provenientes de esgotos industriais geradas nas bacias indicadas Fonte:Adaptado de São Paulo (2000)

As fontes difusas de poluição urbanas e rurais constituem-se em significativa e importante contribuição para a degradação dos recursos hídricos, mas não existem informações que permitam analisar a situação atual na UGRHI 05 PCJ. O Plano de bacias 2000-2003 da UGRHI 05 PCJ considera a gravidade do problema relacionado à carga difusa gerada a partir da extensa aplicação de agrotóxicos na UGRHI.

As Figuras 27 e 28 apresentam os Índices de Qualidade das Águas (IQA) e Índices de Qualidade das Águas Brutas para fins de Abastecimento Público 
(IAP) determinados pela CETESB, para o ano de 2002, para todos os pontos de monitoramento da bacia do rio Piracicaba. 


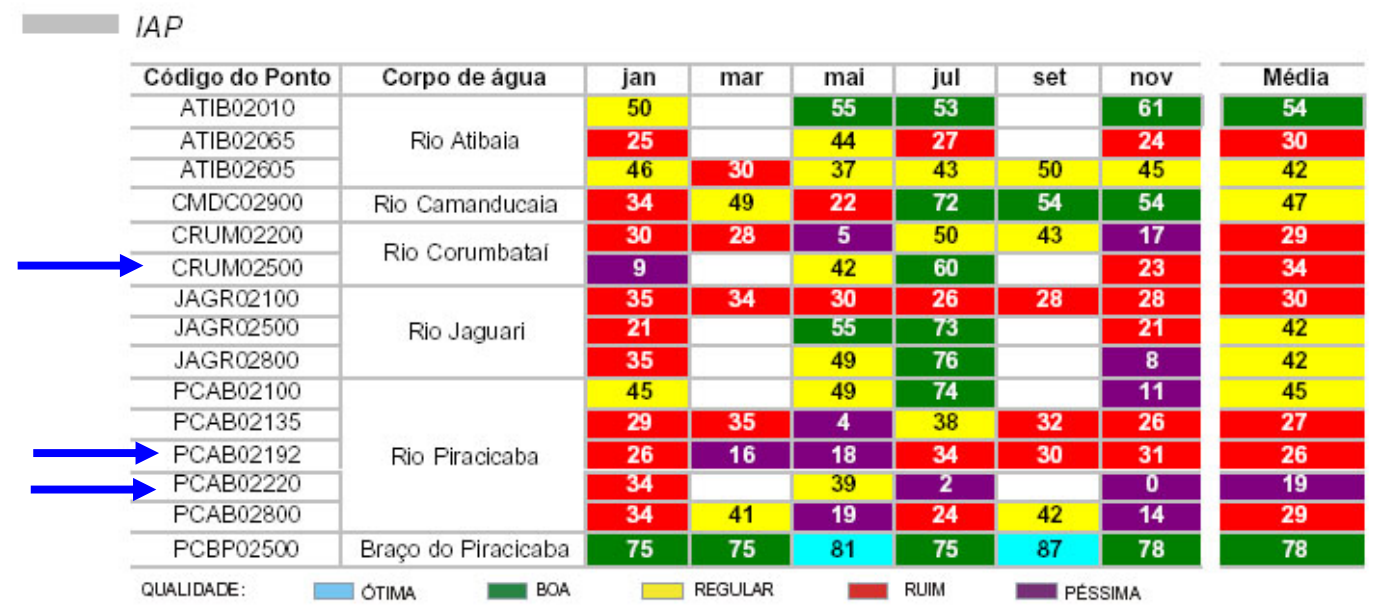

Figura 27 - IAP no ano de 2002 para a bacia hidrográfica do rio Piracicaba Fonte: CETESB (2003)

a Resultados mensais e média anual do IAP - 2003

\begin{tabular}{|c|c|c|c|c|c|c|c|c|c|}
\hline Código do Ponto & CORPO DE AGUA & JAN & MAR & MAI & JUN & JUL & SET & NOV & MÉDIA \\
\hline JAGR02100 & \multirow{3}{*}{ Rio Jaguari } & 18 & 25 & & 30 & 26 & 15 & 24 & 23 \\
\hline JAGR02500 & & & & & 63 & 64 & & & 63 \\
\hline JAGR02800 & & 8 & & & 56 & 57 & & 12 & 33 \\
\hline CMDC02900 & Rio Camanducaia & & 45 & & 60 & 66 & 55 & 24 & 50 \\
\hline ATIB02010 & \multirow{3}{*}{ Rio Atibaia } & 6 & & & & 55 & & 12 & 24 \\
\hline ATIB02065 & & 18 & & & & 45 & & 8 & 24 \\
\hline AT1B02605 & & 24 & 40 & 48 & & 44 & 51 & 46 & 42 \\
\hline PCAB02100 & \multirow{5}{*}{ Rio Pracicaba } & 11 & & 58 & & 66 & & 48 & 46 \\
\hline PCAB02135 & & 30 & 25 & 25 & & 24 & 19 & 25 & 25 \\
\hline PCAB02192 & & 16 & 29 & & 26 & 32 & 18 & 33 & 26 \\
\hline РCAB02220 & & 4 & & 9 & & 5 & & 0 & 5 \\
\hline PCAB02800 & & 32 & 30 & 45 & & 35 & 28 & 11 & 30 \\
\hline РCBP02500 & Braço do Piracicabe & 58 & 49 & 85 & & 83 & 72 & 77 & 71 \\
\hline CRUM02200 & \multirow{2}{*}{ Rio Corumbatai } & 30 & 40 & 41 & & 44 & 36 & 26 & 36 \\
\hline CRUM02500 & & 2 & & 27 & & 58 & & 39 & 32 \\
\hline
\end{tabular}

Figura 28- IAP no ano de 2003 para a bacia hidrográfica do rio Piracicaba Fonte: CETESB (2004) 


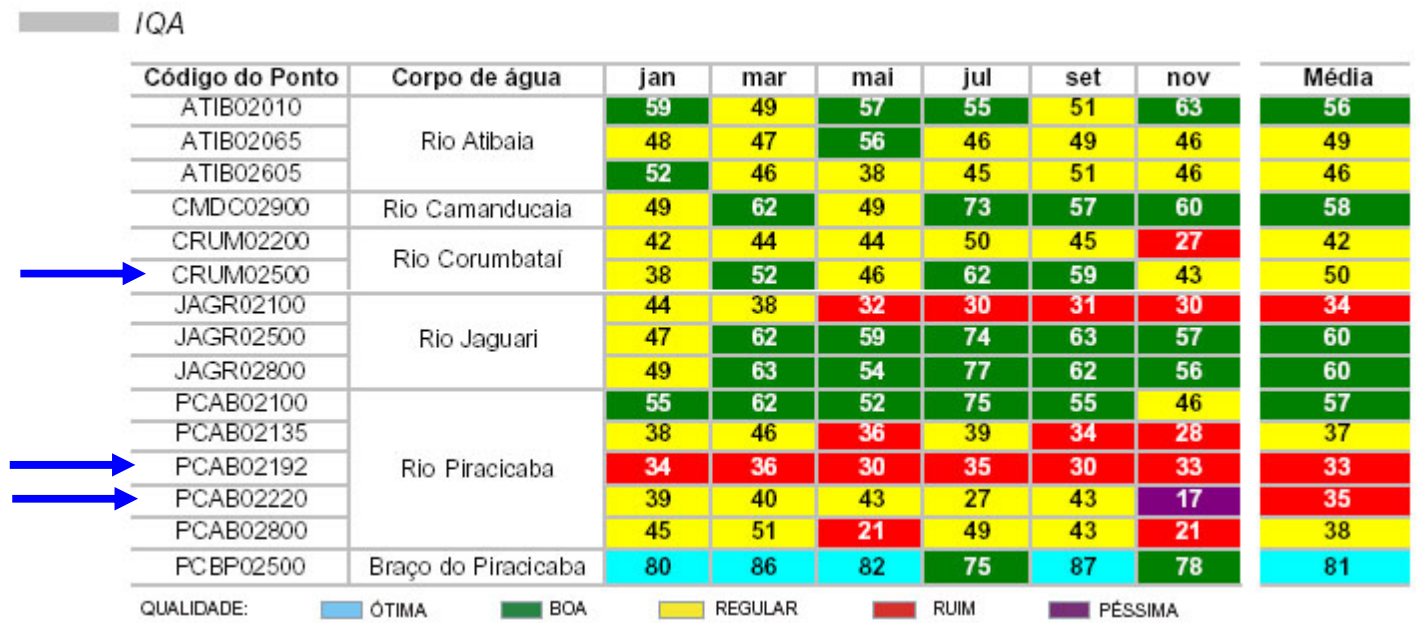

Figura 29 - IQA para a bacia hidrográfica do rio Piracicaba Fonte: CETESB (2003)

- Resultados mensais e média anual do IQA - 2003

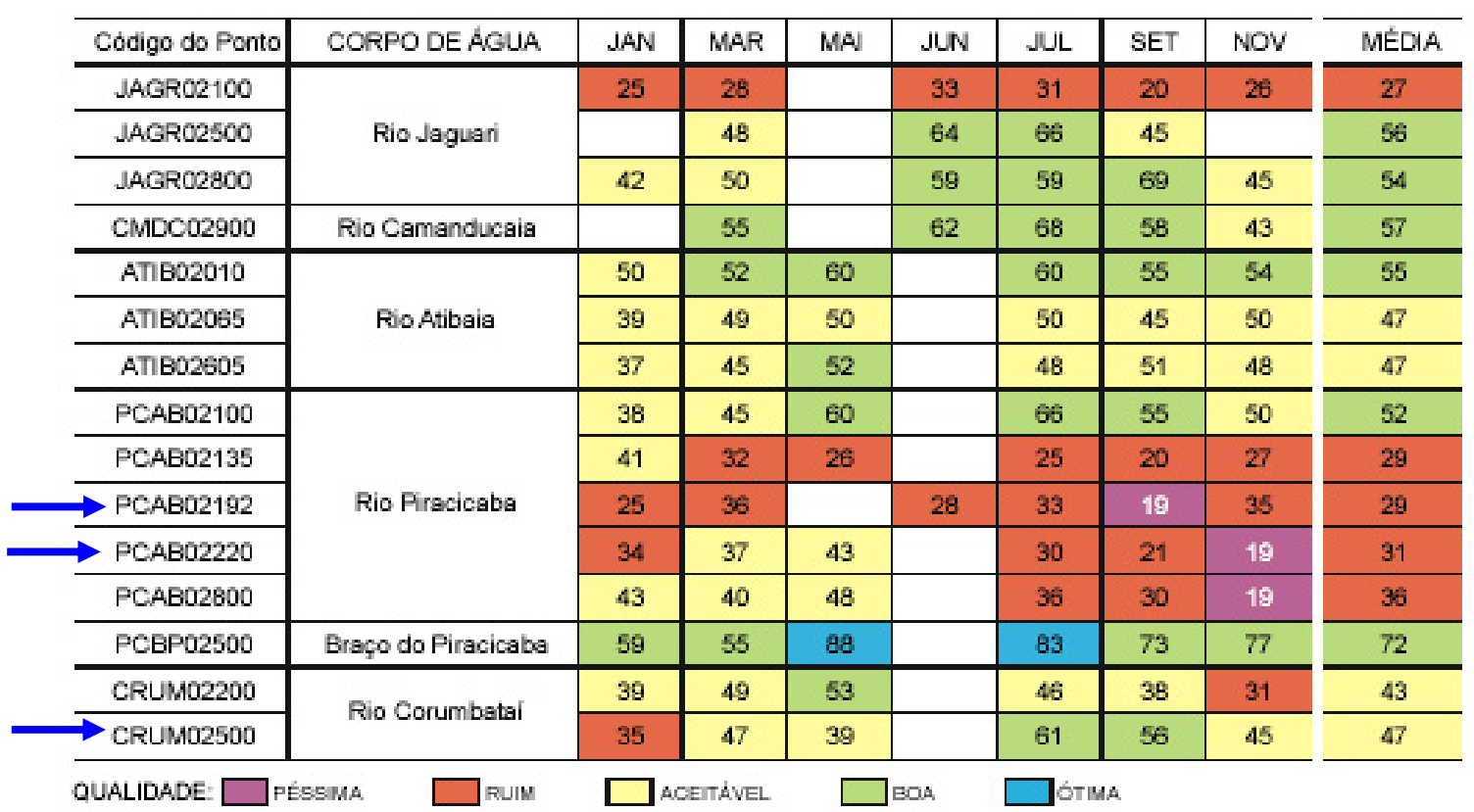

Figura 30- IQA no ano de 2003 para a bacia hidrográfica do rio Piracicaba Fonte: CETESB (2004) 
pontos sobre os quais se analisa a evolução histórica de qualidade das águas dos rios Piracicaba e Corumbataí neste estudo. Estes pontos estão descritos no Quadro 22. A Figura 31 localiza estes pontos e outros que compõem parte da rede de monitoramento da CETESB.

\begin{tabular}{|c|c|c|c|}
\hline Corpo de água & $\begin{array}{c}\text { Código do } \\
\text { ponto }\end{array}$ & Descrição & $\begin{array}{c}\text { Período de } \\
\text { dados }\end{array}$ \\
\hline Rio Piracicaba & PCAB02192 & $\begin{array}{c}\text { Ponte na estrada Piracicaba/ } \\
\text { Limeira, próximo à Usina Monte } \\
\text { Alegre }\end{array}$ & $\begin{array}{c}1978 \mathrm{a} \\
2003\end{array}$ \\
\hline Rio Piracicaba & PCAB02220 & $\begin{array}{c}\text { Captação de Piracicaba, a 2,5 km } \\
\text { do rio. Piracica-Mirim }\end{array}$ & $\begin{array}{c}1989 \mathrm{a} \\
2003\end{array}$ \\
\hline Rio Corumbataí & CRUM02500 & Captação de Piracicaba & $\begin{array}{c}1978 \text { a } \\
2003\end{array}$ \\
\hline
\end{tabular}

Quadro 22 - Pontos de monitoramento da CETESB nos rios Piracicaba e Corumbataí utilizados na análise da evolução da qualidade da água

Fonte: Adaptado de CETESB(2003)

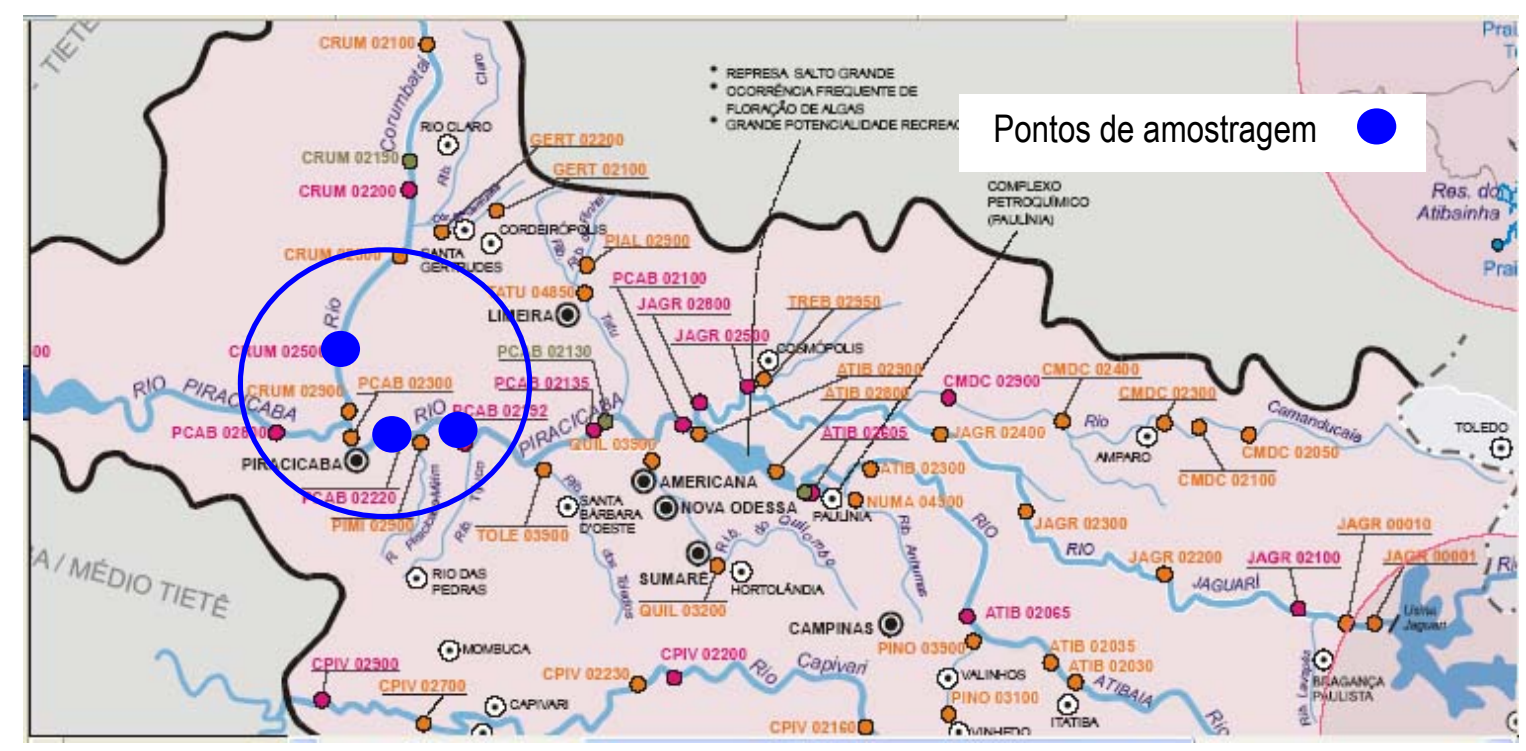

Figura 31 - Localização dos pontos de amostragem nos rios Piracicaba e Corumbataí a serem estudados e outros das redes de monitoramento da CETESB 


\title{
4 MÉTODOS
}

\author{
Para atingir o Objetivo 1 do estudo e estabelecer o custo do \\ tratamento de águas provenientes de bacias hidrográficas com diferentes \\ percentuais de cobertura florestal foram levantados e organizados dados relativos \\ aos mananciais, sistemas de captação e tratamento de todas as ETAs estudadas. \\ Todos os dados foram coletados diretamente com as operadoras dos serviços de \\ abastecimento público, salvo alguns dados de qualidade dos mananciais. Os dados \\ coletados pretenderam contemplar à determinação das seguintes informações: \\ - custos referentes ao consumo de energia elétrica nas captações e na ETA; \\ - custos referentes ao consumo de produtos químicos na ETA; \\ - vazão captada, população abastecida e qualidade do manancial de \\ abastecimento público; \\ - percentual de cobertura florestal da bacia hidrográfica de captação e área de \\ drenagem da bacia.; \\ - volume de lodo gerado na ETA;
}

Para alcançar o Objetivo 2 do estudo e mostrar as perspectivas sobre a qualidade das águas do rio Corumbataí como manancial de abastecimento público de Piracicaba, foi realizado o confronto da caracterização física, sócioeconômica, ambiental e de planejamento entre a bacia do rio Corumbataí e a bacia do rio Piracicaba. Foi realizada análise comparativa entre as duas unidades de estudo a ser descrita em cada subitem deste segmento. Todos os dados sócio econômicos e de planejamento foram levantados para cada município integrante das bacias hidrográficas. Como a qualidade das águas do rio Piracicaba sofre também interferência direta das contribuições recebidas pelos seus formadores, 
os rios Atibaia e Jaguari, foram considerados para a análise dados de todos os municípios das bacias dos rios Piracicaba, Atibaia e Jaguari pertencentes à UGRHI 05. Os dados levantados pretenderam confrontar as seguintes situações:

. meio físico;

· uso e ocupação do solo;

- demografia;

- disponibilidade hídrica;

- qualidade das águas dos rios Piracicaba e Corumbataí

· caracterização econômica;

- instrumentos de planejamento municipal;

· índices sociais disponíveis.

\subsection{Custo do tratamento de água $x$ cobertura florestal da bacia}

\subsubsection{Determinação de custos operacionais das 7 Estações de Tratamento de Água e Captações}

A qualidade dos mananciais está diretamente relacionada com a qualidade da água servida à população e ao custo operacional das ETAs, que se reflete no valor cobrado pela água , da população atendida pelo serviço de abastecimento. $O$ volume de produtos químicos consumidos em uma estação de tratamento de águas está diretamente relacionado com a turbidez da água bruta, que usualmente eleva-se no período de chuvas, que para a região abrangida no presente estudo corresponde aos meses de novembro a março. O aumento de turbidez está associado à elevação da concentração de sólidos dissolvidos na água, podendo aumentar a possibilidade de comprometimento da qualidade das águas tratadas.

Desta cadeia de inter-relações conclui-se que o custo de operação de uma ETA está relacionado com a qualidade do manancial, qualidade esta que sofre influência do percentual de cobertura florestal da bacia hidrográfica de origem.

Conforme informações de algumas das fontes de estudo, dentre os custos operacionais mais representativos numa ETA estão: consumo de produtos químicos, pessoal (salários e encargos), energia, compra de materiais diversos, 
transporte. O custo com produtos químicos representa, em média, cerca de $60 \%$ do custo final de operação de uma ETA. Os demais custos representam respectivamente: pessoal, $29 \%$; energia elétrica, $6 \%$; compra de materiais diversos, 3,5\%; transporte, $0,6 \%$.

Os custos operacionais das ETAs eleitos para o estudo foram: custo com produtos químicos e custo com energia elétrica, que compõem cerca de $66 \%$ do custo final de operação. Tendo em vista a falta de acesso ao custo com pessoal, esta parcela não foi considerada, apesar de aparentemente representativa.

O custo referente à operação de captação de água bruta considerado neste trabalho resume-se ao consumo de energia elétrica, por ser o mais significativo dentre os custos existentes para esta etapa do processo e ainda por ser o dado de obtenção imediata disponível junto às ETAs.

Não serão considerados custos de manutenção ou de remuneração de pessoal. A análise não aborda também qualquer avaliação de custos referentes a obras.

As ETAs forneceram valores mensais de consumo de produtos para 0 ano de 2002 e, com preços específicos de cada produto para o ano de 2002, foram obtidos os valores de custo dos produtos para a operação de cada estação.

As ETAs disponibilizaram os custos mensais com energia elétrica para a captação e para a operação da ETA durante o ano de 2002, ou, em alguns casos, o custo médio anual para o ano de 2002.

Para que a análise comparativa de custo do tratamento das águas seja possível, serão calculados os custos específicos de produtos químicos e energia elétrica consumidos, considerando-se a vazão de água tratada na ETA como unidade. Todo o cálculo dos custos específicos será gerado a partir da média de consumo mensal de volumes aduzidos de água bruta, produtos químicos e energia elétrica, consumidos, para o ano de 2002.

O preço unitário dos produtos químicos foi admitido como sendo o mesmo para todas as ETAs analisadas, com o objetivo de padronizar a comparação dos custos específicos, tendo como base o ano de 2002.

Vale ressaltar que o consumo de produtos químicos e a periodicidade de lavagem de unidades da ETA em períodos chuvosos são maiores do que na estiagem. Entretanto, o cálculo de custos específicos de produtos químicos e energia consumidos, para a época chuvosa apenas, ou para a estiagem, não apresentou diferenças 
significativas. Assim, o cálculo apresentado refere-se à média mensal para o ano completo, de Janeiro à Dezembro.

As fórmulas listadas de (1) a (5) sintetizam a idéia do valor a ser utilizado na análise comparativa de custos das ETAs, associados à qualidade e ocupação dos diferentes mananciais.

\begin{tabular}{|c|c|}
\hline $\begin{array}{c}\text { Custo específico de produtos químicos = custo de } \\
\text { produtos químicos } / 1000 \mathrm{~m}^{3} \text { vazão tratada na } \\
\text { ETA }\end{array}$ & (1) \\
\hline $\begin{array}{c}\text { Custo específico de consumo de energia elétrica } \\
\text { na ETA = custo da energia elétrica na ETA/1000 } \\
\mathrm{m}^{3} \text { vazão tratada na ETA- }\end{array}$ & (2) \\
\hline $\begin{array}{c}\text { Custo específico de consumo de energia elétrica } \\
\text { na captação }=\text { custo da energia elétrica na } \\
\text { captação/1000 } \mathrm{m}^{3} \text { vazão tratada na ETA }\end{array}$ & (3) \\
\hline $\begin{array}{c}\text { Custo específico de consumo de energia } \\
\text { +produtos químicos na ETA = custo (energia } \\
\text { elétrica + produtos químicos) na ETA } / 1000 \mathrm{~m}^{3} \\
\text { vazão tratada na ETA }\end{array}$ & (4) \\
\hline $\begin{array}{c}\text { Custo específico de consumo de energia } \\
\text { +produtos químicos na ETA e captação }=\text { custo } \\
\text { (energia elétrica + produtos químicos) na ETA e } \\
\text { captação } / 1000 \mathrm{~m}^{3} \text { vazão tratada na ETA }\end{array}$ & (5) \\
\hline
\end{tabular}

Quadro 23 - Estrutura do cálculo dos Custos específicos de produtos químicos e energia elétrica das ETAs e suas captações

\subsubsection{Qualidade dos mananciais dos 7 sistemas de abastecimento público de água}

Os mananciais de abastecimento público são, em geral, monitorados pelas companhias responsáveis pela captação, tratamento e distribuição das águas. O monitoramento da qualidade das águas diverge de uma unidade para outra, entretanto, parâmetros como turbidez e oxigênio dissolvido, são usualmente medidos; a turbidez, por ser um parâmetro de controle operacional e o oxigênio dissolvido, por ser representativo da qualidade da água bruta e estar associado à presença de contaminantes, ou algas, ou mesmo muitos sólidos em suspensão.

As companhias forneceram dados de qualidade para o ano de 2002. Entretanto, para alguns mananciais foi possível a obtenção de alguns dados históricos 
obtidos junto à CETESB e às próprias companhias de água, tornando a informação mais representativa. O Sistema Cantareira possui diversos pontos de monitoramento e optou-se por trabalhar com um valor médio obtido para o Reservatório Jaguari, que tem o maior volume de água do sistema. Com o objetivo de dar caráter menos genérico aos dados de qualidade dos mananciais, a turbidez e o oxigênio dissolvido (OD) foram determinados para a época de estiagem (entre abril e outubro) e para a época de chuvas (entre novembro e março).

A organização de todos os dados vem acompanhada do percentual de cobertura florestal de cada bacia hidrográfica.

\subsection{Geração de lodo nas 7 Estações de Tratamento de Água}

Os parâmetros cor e turbidez são fundamentais para definir as dosagens de produtos químicos à água bruta que entra nas estações de tratamento de água. Valores mais altos desses parâmetros implicam em dosagens mais elevadas de produtos químicos e em maior geração de lodo nas unidades de tratamento.

As ETAs possuem descargas rotineiras das unidades de decantação e de filtração, que são ricas em sólidos e que devem ser tratadas em unidades de secagem e dispostas de forma ambientalmente adequada. Essa descarga de material sólido é chamada de lodo. O lodo concentra todas as impurezas agregadas através dos processos de coagulação e floculação na entrada da ETA e retidas nas unidades de decantação e filtração.

Nenhuma das ETAs estudadas possui estação de tratamento para este lodo. Algumas unidades de estudo já possuem estações de desidratação de lodo calculadas e projetadas. Os valores estimados para a geração de lodo admitem densidade do lodo igual a um (1) $\mathrm{Kg} / \mathrm{m}^{3}$. A Figura 32 apresenta de forma simplificada as etapas de tratamento do lodo numa ETA. 


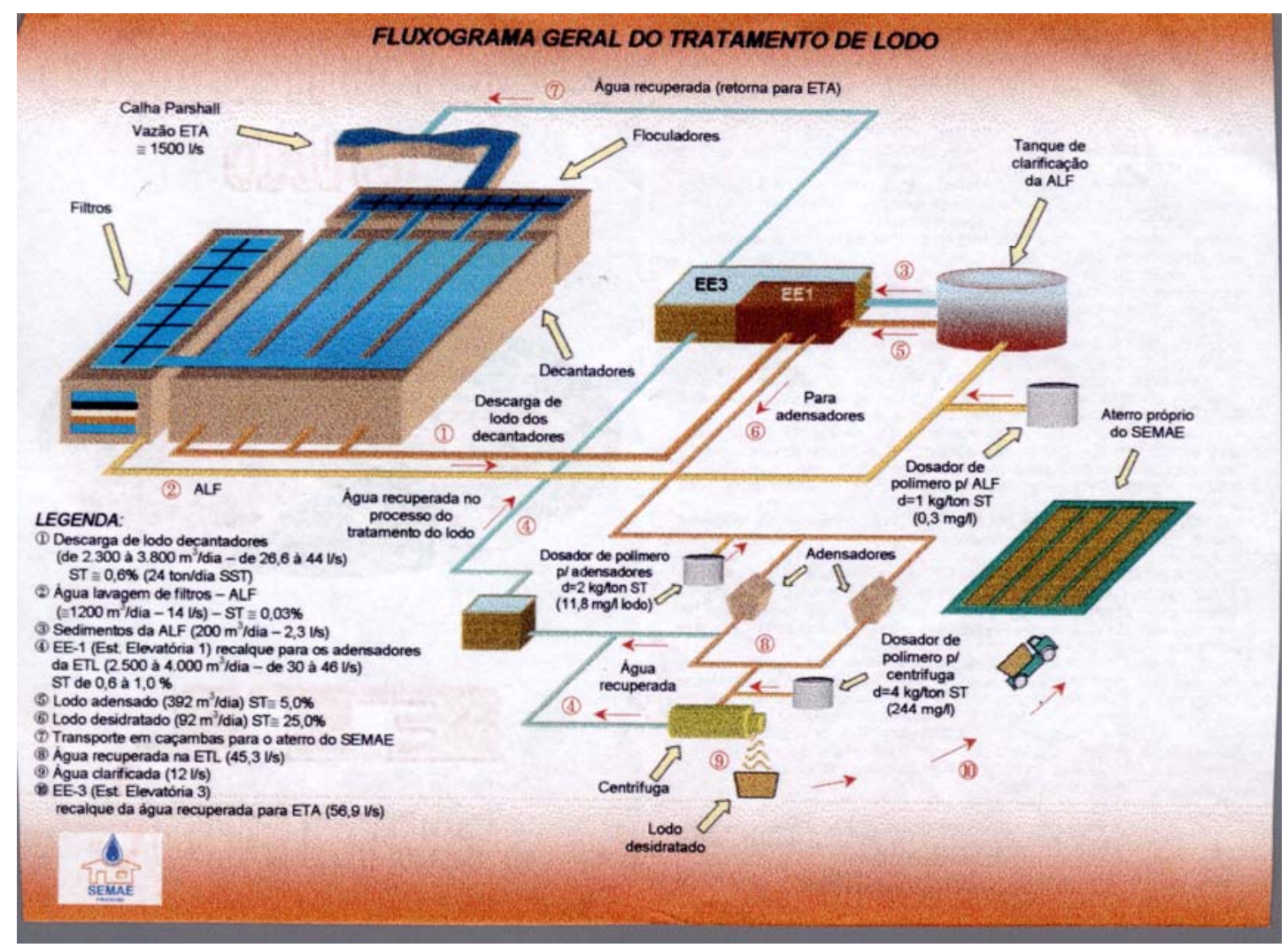

Figura 32 - Fluxograma Geral Tratamento de Lodo

O volume de lodo gerado em cada ETA refere-se a valor teórico resultante de processos de tratamento de lodo com unidades de adensamento e, por exemplo, centrifugação. O valor é teórico já que nenhuma delas possui tratamento de lodo implantado e em operação. O volume de lodo foi fornecido diretamente pelas operadoras, direta ou indiretamente. Os volumes determinados pressupõem o lodo desidratado, mas ainda com teor de umidade em torno de $75 \%$.

A quantidade teórica de lodo especificada corresponde àquela que deverá ser adequadamente disposta. Quanto maior a turbidez maior o volume especifico de lodo gerado na ETA e portanto maior será o custo com o tratamento e disposição do lodo. Estes custos adicionais não foram portanto determinados neste estudo. A determinação de custo adicional para as etapas de tratamento e disposição final do lodo poderá ser futuramente realizada, a fim de complementar o custo do tratamento da água definido neste trabalho.

Os volumes específicos teóricos de lodo gerados nas sete unidades de 
estudo foram listados e confrontados com o percentual de cobertura florestal de cada bacia hidrográfica.

\subsection{Rio Corumbataí x Rio Piracicaba: perspectivas de manutenção da qualidade de um manancial de abastecimento público}

O confronto dos dados obtidos para as duas bacias referem-se à: meio físico, uso e ocupação do solo, demografia, disponibilidade hídrica; qualidade das águas dos rios Piracicaba e Corumbataí, caracterização econômica, instrumentos de planejamento municipal e índices sociais disponíveis.

Os dados sobre meio físico, uso e ocupação do solo e os estudo demográfico de projeção futura de populações foram definidos para as duas bacias hidrográficas em estudo.

Os dados de qualidade dos rios Piracicaba e Corumbataí foram organizados para um ponto de amostragem no rio Corumbataí e dois pontos de amostragem no rio Piracicaba, com histórico de pelo menos 22 anos, para os parâmetros determinados.

Os dados sócio econômicos e de planejamento municipal foram levantados para cada município integrante das duas bacias hidrográficas. A opção de trabalhar com dados municipais fez-se necessária, pois as regiões administrativas de gestão do Estado de São Paulo, para diferentes setores, são diversas e não obedecem a limites necessariamente coincidentes; as informações desejadas neste caso não estavam disponibilizadas para as bacias hidrográficas dos rios Piracicaba e Corumbataí.

Como a qualidade das águas do rio Piracicaba sofre também interferência direta das contribuições recebidas pelos seus formadores, os rios Atibaia e Jaguari, foram considerados para a análise dados de todos os municípios das bacias dos rios Piracicaba, Atibaia e Jaguari pertencentes à UGRHI 05.

Importante salientar que a caracterização político administrativa das bacias, especificamente os municípios considerados incluídos em cada bacia podem ser diferentes, dependendo da fonte de pesquisa. $\underline{\mathrm{O} \text { trabalho considerou para análise, } \mathrm{a}}$ inclusão de municípios consagrada para a Unidade de Gerenciamento de Recursos Hídricos do Estado de São Paulo 05, UGRHI 05. Os dados sócio-econômicos foram levantados exclusivamente para os municípios pertencentes ao Estado de São Paulo; 
os dados relativos aos municípios pertencentes ao Estado de Minas Gerais não foram considerados neste estudo e entende-se que não haverá prejuízo das conclusões.

Dessa maneira, a bacia hidrográfica do rio Piracicaba será analisada através de $\mathbf{4 0}$ municípios e a bacia hidrográfica do rio Corumbataí, pelo universo de $\mathbf{7}$ municípios. Ressalta-se que o município de Piracicaba foi listado nas duas bacias, pois seus limites territoriais estendem-se às duas unidades, o que justifica essa inclusão.

Com o objetivo de refletir, de maneira mais fiel e menos generalista, o comportamento dos municípios para os dados sócio econômicos e de planejamento municipal, utilizou-se o recurso de segmentar os municípios em oito faixas de população, a saber:

\begin{tabular}{|l|c|}
\hline 1 & Municípios com população < 5.000 habitantes \\
\hline 2 & Municípios com população entre 5.000 e 15.000 habitantes \\
\hline 3 & Municípios com população entre 15.000 e 50.000 habitantes \\
\hline 4 & Municípios com população entre 50.000 e 100.000 habitantes \\
\hline 5 & Municípios com população entre 100.000 e 200.000 habitantes \\
\hline 6 & Municípios com população entre 200.000 e 350.000 habitantes \\
\hline 7 & Municípios com população entre 350.000 e 500.000 habitantes \\
\hline 8 & Municípios com população > 500.000 habitantes \\
\hline
\end{tabular}

A classificação dos municípios por faixa de população em 2000 (IBGE) e por unidade de estudo está apresentada no Quadro 24.

O Quadro 25 mostra as classes de municípios por população em 2000 (IBGE), a população e o percentual correspondente a cada classe, por unidade de estudo. 


\begin{tabular}{|c|c|c|}
\hline \multicolumn{3}{|c|}{ Bacia do rio Piracicaba } \\
\hline Município & $\begin{array}{l}\text { População em } \\
2000 \text { (IBGE) }\end{array}$ & $\begin{array}{l}\text { Classe de município por } n^{0} \text { de } \\
\text { habitantes }\end{array}$ \\
\hline Águas de São Pedro & 1.845 & $<5.000$ \\
\hline Santa Maria da Serra & 4.619 & $<5.000$ \\
\hline Tuiuti & 4.933 & $<5.000$ \\
\hline Subtotal & 11.397 & $0,35 \%$ \\
\hline Bom Jesus dos Perdões & 13.213 & entre 5.000 e 15.000 \\
\hline Holambra & 7.231 & entre 5.000 e 15.000 \\
\hline Joanópolis & 10.388 & entre 5.000 e 15.000 \\
\hline Monte Alegre do Sul & 6.323 & entre 5.000 e 15.000 \\
\hline Morungaba & 9.919 & entre 5.000 e 15.000 \\
\hline Nazaré Paulista & 14.379 & entre 5.000 e 15.000 \\
\hline Pedra Bela & 5.604 & entre 5.000 e 15.000 \\
\hline Pinhalzinho & 10.917 & entre 5.000 e 15.000 \\
\hline Saltinho & 5.775 & entre 5.000 e 15.000 \\
\hline Vargem & 6.975 & entre 5.000 e 15.000 \\
\hline Subtotal & 90.724 & $2,77 \%$ \\
\hline Artur Nogueira & 33.089 & entre 15.000 e 50.000 \\
\hline Cordeirópolis & 17.586 & entre 15.000 e 50.000 \\
\hline Cosmópolis & 44.367 & entre 15.000 e 50.000 \\
\hline Iracemápolis & 15.524 & entre 15.000 e 50.000 \\
\hline Jaguariúna & 29.450 & entre 15.000 e 50.000 \\
\hline Jarinu & 17.677 & entre 15.000 e 50.000 \\
\hline Monte Mor & 37.111 & entre 15.000 e 50.000 \\
\hline Nova Odessa & 42.066 & entre 15.000 e 50.000 \\
\hline Pedreira & 35.242 & entre 15.000 e 50.000 \\
\hline Piracaia & 22.986 & entre 15.000 e 50.000 \\
\hline Rio das Pedras & 23.441 & entre 15.000 e 50.000 \\
\hline Santo Antônio da Posse & 18.145 & entre 15.000 e 50.000 \\
\hline São Pedro & 27.866 & entre 15.000 e 50.000 \\
\hline Vinhedo & 47.104 & entre 15.000 e 50.000 \\
\hline Subtotal & 411.654 & $12,60 \%$ \\
\hline Amparo & 60.415 & entre 50.000 e 100.000 \\
\hline Itatiba & 80.884 & entre 50.000 e 100.000 \\
\hline Paulínia & 51.242 & entre 50.000 e 100.000 \\
\hline Valinhos & 82.773 & entre 50.000 e 100.000 \\
\hline Subtotal & 275.314 & $8,42 \%$ \\
\hline Americana & 182.084 & entre 100.000 e 200.000 \\
\hline
\end{tabular}

Quadro 24- Classificação dos municípios por faixa de população em 2000 (IBGE) e por unidade de estudo 


\begin{tabular}{|c|c|c|}
\hline Atibaia & 111.055 & entre 100.000 e 200.000 \\
\hline Bragança Paulista & 124.888 & entre 100.000 e 200.000 \\
\hline Hortolândia & 151.669 & entre 100.000 e 200.000 \\
\hline Santa Bárbara d'Oeste & 169.735 & entre 100.000 e 200.000 \\
\hline Sumaré & 196.055 & entre 100.000 e 200.000 \\
\hline Subtotal & 935.486 & $\mathbf{2 8 , 6 1 \%}$ \\
\hline Limeira & 248.632 & entre 200.000 e 350.000 \\
\hline Piracicaba & 328.312 & entre 200.000 e 350.000 \\
\hline Subtotal & 576.944 & $17,65 \%$ \\
\hline Campinas & 967.921 & $>500.000$ \\
\hline Subtotal & $\mathbf{9 6 7 . 9 2 1}$ & $\mathbf{2 9 , 6 0 \%}$ \\
\hline TOTAL & $\mathbf{3 . 2 6 9 . 4 4 0}$ & \\
\hline
\end{tabular}

Quadro 24 -Classificação dos municípios por faixa de população em 2000 (IBGE)-bacia do rio Piracicaba

\begin{tabular}{|c|c|c|}
\hline \multicolumn{3}{|c|}{ Bacia do rio Corumbataí } \\
\hline Município & $\begin{array}{c}\text { População em } \\
2000 \text { (IBGE) }\end{array}$ & Classe de município por $\mathrm{n}^{0}$ de habitantes \\
\hline Analândia & 3.579 & $<5.000$ \\
\hline Corumbataí & 3.796 & $<5.000$ \\
\hline Ipeúna & 4.318 & $<5.000$ \\
\hline Subtotal & 11.693 & $<5.000$ \\
\hline Charqueada & 13.001 & entre 5.000 e 15.000 \\
\hline Subtotal & 13.001 & entre 5.000 e 15.000 \\
\hline Santa Gertrudes & 15.898 & entre 15.000 e 50.000 \\
\hline Subtotal & 15.898 & entre 15.000 e 50.000 \\
\hline Rio Claro & 168.087 & entre 100.000 e 200.000 \\
\hline Subtotal & 168.087 & entre 100.000 e 200.000 \\
\hline Piracicaba & 328.312 & entre 200.000 e 350.000 \\
\hline Subtotal & 328.312 & entre 200.000 e 350.000 \\
\hline TOTAL & 536.991 & \\
\hline
\end{tabular}

Quadro 25 - Classificação dos municípios por faixa de população em 2000 (IBGE) -bacia do rio Corumbataí 


\begin{tabular}{|c|c|c|c|c|}
\hline & \multicolumn{2}{|c|}{ Bacia do rio Piracicaba } & \multicolumn{2}{|c|}{ Bacia do rio Corumbataí } \\
\hline $\begin{array}{c}\text { Classes por n } \\
\text { habitantes em } \\
\text { 2000(IBGE) }\end{array}$ & $\begin{array}{c}\text { \% da } \\
\text { população } \\
\text { por classe }\end{array}$ & $\begin{array}{c}\text { População } \\
\text { em 2000 } \\
\text { (IBGE) } \\
\text { (hab) }\end{array}$ & $\begin{array}{c}\text { \% da } \\
\text { população } \\
\text { por classe }\end{array}$ & $\begin{array}{c}\text { População } \\
\text { em } \\
\text { 2000(IBGE) } \\
\text { (hab) }\end{array}$ \\
\hline$<5.000$ hab & $0,35 \%$ & 11.397 & $5,60 \%$ & 11.693 \\
\hline entre 5.000 e 15.000 hab & $2,77 \%$ & 90.724 & $6,23 \%$ & 13.001 \\
\hline entre 15.000 e 50.000 hab & $12,60 \%$ & 411.654 & $7,62 \%$ & 15.898 \\
\hline $\begin{array}{c}\text { entre } 50.000 \text { e } 100.000 \\
\text { hab }\end{array}$ & $8,42 \%$ & 275.314 & $0 \%$ & 0 \\
\hline $\begin{array}{c}\text { entre 100.000 e } 200.000 \\
\text { hab }\end{array}$ & $28,61 \%$ & 935.486 & $80,55 \%$ & 168.087 \\
\hline $\begin{array}{c}\text { entre 200.000 e } 350.000 \\
\text { hab }\end{array}$ & $0 \%$ & 0 & $0 \%$ & 0 \\
\hline $\begin{array}{c}\text { entre 350.000 e } 500.000 \\
\text { hab }\end{array}$ & $29,60 \%$ & 967.921 & $0 \%$ & 0 \\
\hline$>500.000$ hab & $17,65 \%$ & 576.944 & $0 \%$ & 0 \\
\hline Total & $100,00 \%$ & 3.269 .440 & $100 \%$ & 208.679 \\
\hline
\end{tabular}

Quadro 26 - Classes de municípios por faixa, população e percentual correspondente por unidade de estudo, para o ano 2000 (IBGE)

A análise do comportamento das bacias para os dados sócio econômicos e de planejamento municipal é resultado da média do comportamento de cada município pertencente à bacia em questão, ou à faixa de municípios analisada, estabelecida no início deste item.

A documentação e os registros sobre as bacias hidrográficas dos rios Piracicaba e Corumbataí são inúmeros. Porém, os registros de dados ligados aos setores econômicos (indústria, agricultura, comércio e serviços) são caracterizados por descontinuidade ou organização mais recente de dados, impossibilitando na maioria dos casos, análises da evolução do comportamento econômico de municípios em horizonte superior aos últimos dez anos. 


\title{
4.3.1 Meio Físico, Uso e Ocupação do solo e Disponibilidade Hídrica
}

\begin{abstract}
A partir da descrição das duas unidades de estudo, a bacia do rio Piracicaba e a bacia do rio Corumbataí, para os aspectos do meio físico, uso e ocupação do solo e disponibilidade hídrica, o estudo se propõe a apontar vulnerabilidades e aspectos favoráveis para a manutenção da bacia do rio Corumbataí como principal manancial de abastecimento público do município de Piracicaba, através da comparação dos registros e características do meio.
\end{abstract}

\subsubsection{Demografia}

As análises da evolução do comportamento dos municípios foram realizadas de forma comparativa entre as duas unidades de estudo de acordo com a seguinte organização:

Taxas geométricas médias de crescimento da população total para os três períodos estudados: análise da evolução das taxas de acordo com as faixas de divisão populacional estabelecidas para as duas unidades de estudo;

Taxas geométricas médias de crescimento da população total para os três períodos estudados: análise da evolução das taxas para as duas unidades de estudo, sem considerar divisão de municípios por faixa populacional;

Taxas geométricas de crescimento da população total, por município, para os três períodos estudados: análise do percentual de municípios que superam a taxa de crescimento da população total da Região Administrativa de Campinas, na bacia hidrográfica do rio Piracicaba e na a bacia hidrográfica do rio Corumbataí, para cada um dos três períodos estudados;

O método utilizado na análise deste estudo é o de confronto e comparação das situações registradas para os diversos agrupamentos de municípios em classes de população das duas unidades de estudo.

A análise consiste na observação do comportamento das taxas de crescimento populacional destes municípios, buscando identificar o histórico, relacionálo com regiões desenvolvidas do Estado e vislumbrar perspectivas de ocupação da 
bacia do rio Corumbataí.

\subsubsection{Caracterização Econômica}

Na busca de caracterizar a riqueza dos municípios e a evolução desta riqueza ao longo do tempo, diversas tentativas na busca de valores representativos foram feitas. No entanto, devido à descontinuidade de levantamentos e muitas lacunas em dados oficiais, optou-se por trabalhar com o registro fiscal do Estado de São Paulo intitulado Valor Adicionado Total de cada município. O Valor Adicional Total é um índice oficial do Estado de São Paulo, resultante do registro de produtos, serviços e outros que advém do município para a receita do Estado. Infelizmente o período de dados disponíveis era apenas de 1993 a 2002, não promovendo assim a busca de dados das décadas de 60/70 e 80, que seriam importantes para melhor compreensão do histórico de desenvolvimento dos municípios em cada unidade de estudo.

O índice oficial oferece o risco de omitir parte da realidade econômica do município, seja pelo não pagamento de impostos ou por outras razões de interesses diversos. Entretanto, diante da necessidade de qualificar a dinâmica da economia nos municípios, de forma a observar se há manutenção no seu crescimento, queda de riqueza do município ou estagnação, foi mantida a escolha deste índice como indicativo do comportamento da economia dos municípios.

A análise da evolução do comportamento dos municípios foi realizada de forma comparativa entre as duas unidades de estudo de acordo com as classes de população definidas no estudo. Para cada classe de municípios existente na bacia do rio Piracicaba e na bacia do rio Corumbataí, foram obtidos os valores médios dos Valores Adicionados Totais ao longo do período de 1993 a 2002.

Na análise deste índice não é possível estabelecer um valor padrão que possa servir de parâmetro de comparação para o valor econômico agregado para cada município, ou para os municípios agrupados em classes. Assim, o objetivo que será perseguido pelo estudo, será a identificação do comportamento da economia da média dos municípios das unidades de estudo e sua associação com a qualidade ambiental das bacias de estudo, já que um dos impulsionadores da perda da qualidade das águas do rio Piracicaba foi exatamente o crescimento econômico crescente dos municípios da bacia. 


\subsubsection{Instrumentos de Planejamento Municipal}

As variáveis que visaram caracterizar o município e seus instrumentos de planejamento municipal foram organizadas para as duas unidades de estudo referentes a:

- incentivos para a implantação de empreendimentos através da isenção de taxas,

- incentivos para a implantação de empreendimentos através da doação de terrenos

· existência de Lei de Plano Diretor Municipal.

Os dados foram obtidos para o ano de 1997, junto ao SEADE (2003).

Os resultados foram apresentados na forma de dados percentuais para as duas categorias de incentivo à implantação de empreendimentos e para a existência do Plano Diretor. Os dados para os municípios foram tabulados apenas com sim ou não para cada item.

O percentual foi analisado comparativamente entre as duas bacias para cada um dos três itens compilados, visando obter subsídios para inferir sobre perspectivas para a manutenção do rio Corumbataí como principal manancial de abastecimento público de Piracicaba.

\subsubsection{Qualidade de vida}

A procura por índices que expressassem a qualidade de vida média dos municípios foi arbitrada neste estudo com o objetivo de se verificar uma possível associação, entre o comprometimento ambiental e os índices existentes para medir qualidade de vida dos municípios. Estes índices levantados foram o IDH-M e o IPRS, com definições já detalhadas no item 3.2.9.

O método de análise para visualizar o comportamento do índice IDH-M foi o seguinte:

- os valores médios de IDH-M para cada classe de municípios das duas bacias de estudo foram confrontados em um mesmo gráfico, para os anos estudados, 1980, 1991 e 2000. O objetivo do confronto está na observação do comportamento da 
média dos municípios nas duas unidades de estudo.

Foi feita uma análise do número de municípios com IDH-M considerado alto, para as duas bacias estudadas. Os resultados foram apresentados na forma de dados percentuais para os cinco Grupos de Municípios para cada bacia hidrográfica.

O método de análise para visualizar o comportamento do índice IPRS foi o seguinte:

- os valores médios de IPRS para todos os municípios das duas unidades de estudo foram confrontados em um mesmo gráfico, para os anos estudados, 1992 e 2000. O objetivo do confronto está na observação do comportamento da média dos municípios nas duas unidades de estudo.

\subsubsection{Qualidade das águas}

Para análise da evolução da qualidade das águas dos rios Piracicaba e Corumbataí, foram estabelecidos dois pontos de amostragem para o rio Piracicaba e um ponto para o rio Corumbataí, conforme terminologia definida pela CETESB. Os dados foram extraídos da Rede de Monitoramento da CETESB, que monitora os rios estaduais desde 1978. Os pontos de monitoramento já descritos no item 3.2.6 são repetidos no Quadro 27.

\begin{tabular}{|c|c|c|c|}
\hline Corpo de água & $\begin{array}{c}\text { Código do } \\
\text { ponto } \\
\text { CETESB }\end{array}$ & Descrição & $\begin{array}{c}\text { Período de } \\
\text { dados }\end{array}$ \\
\hline Rio Piracicaba & PCAB02192 & $\begin{array}{c}\text { Ponte na estrada Piracicaba/ } \\
\text { Limeira, próximo à Usina Monte } \\
\text { Alegre }\end{array}$ & $\begin{array}{c}1978 \mathrm{a} \\
2003\end{array}$ \\
\hline Rio Piracicaba & PCAB02220 & $\begin{array}{c}\text { Captação de Piracicaba, a 2,5 km } \\
\text { do rio. Piracica-Mirim }\end{array}$ & $\begin{array}{c}1989 \mathrm{a} \\
2003\end{array}$ \\
\hline Rio Corumbataí & CRUM02500 & Captação de Piracicaba & $\begin{array}{c}1978 \mathrm{a} \\
2003\end{array}$ \\
\hline
\end{tabular}

Quadro 27 - Pontos de monitoramento da CETESB nos rios Piracicaba e Corumbataí utilizados na análise da evolução da qualidade da água

Fonte: Adaptado de CETESB(2003) 
Como o objetivo do estudo é observar o comportamento do manancial ao longo dos anos, conhecido o maior período histórico disponível de parâmetros de qualidade definidos, optou-se por pontos que pudessem fornecer este histórico da qualidade das águas. Desta forma, ainda que estejam disponíveis diversos outros pontos de monitoramento nos rios Piracicaba e Corumbataí, o objetivo não foi traçar um perfil de qualidade dos rios.

Além deste recurso de análise da evolução dos parâmetros nos pontos de monitoramento serão ainda discutidos os índices IAP e IQA para os pontos de captação do município de Piracicaba, nos rios Piracicaba e Corumbataí.

Os parâmetros analisados nos pontos são: Oxigênio Dissolvido (OD), Demanda Bioquímica de Oxigênio (DBO5,20), Cryptosporidium sp e Giárdia sp.

A $\mathrm{DBO}_{5}, 20$, expressa em $\mathrm{mg} / \mathrm{L}$, é normalmente considerada como a quantidade de oxigênio consumido durante 5 dias, numa temperatura de incubação de $20^{\circ} \mathrm{C}$. Ela expressa a demanda de oxigênio solicitada para degradar matéria orgânica presente no meio. Valores elevados de $\mathrm{DBO}_{5,2}$ em corpos de água indicam grau de poluição e contribuição de matéria orgânica incompatíveis com a capacidade de depuração do corpo receptor. Cada classe de rio possui um limite máximo para o parâmetro $\mathrm{DBO}_{5,20}$. Para rios de classe 2, conforme Decreto Estadual 84687/76, o limite máximo deste parâmetro é de $5 \mathrm{mg} / \mathrm{L}$. A grande maioria dos rios das bacias do Piracicaba e Corumbataí são classe 2. Os rios Piracicaba e Corumbataí são classe 2.

O OD, expresso em mg/L, é a quantidade de oxigênio dissolvida na água. Uma adequada provisão de oxigênio dissolvido é essencial para a manutenção de processos de autodepuração em sistemas aquáticos naturais e indicam a capacidade de um corpo receptor de manter a vida aquática. Para rios classe 2, o limite mínimo previsto no Decreto 8468/76 é de $5 \mathrm{mg} / \mathrm{L}$.

O parâmetro turbidez, medido em NTU ou FTU, é amplamente utilizado nas ETAs para o controle e o monitoramento operacional da remoção de material particulado. Outros parâmetros deste tipo utilizados comumente são a cor e a densidade de coliformes termotolerantes. Estes parâmetros não específicos podem ser uma valiosa ferramenta para uma primeira avaliação das características da qualidade de águas em mananciais destinados ao abastecimento público. Também podem ser de grande utilidade para verificar rapidamente mudanças na qualidade da água dentro do processo de tratamento. Além disso, com a preocupação sobre a formação de 
compostos organoclorados leves (como por exemplo, clorofórmio) durante o processo de cloração, chamados trihalometanos, torna-se necessária uma avaliação do manancial em relação à quantidade de precursores destes compostos. A utilização do potencial de formação de trihalometanos, como um parâmetro não específico da medida de precursores de THMs, pode ser usado para comparar a qualidade de vários mananciais de água bruta com potencial para abastecimento, com a possibilidade de produção de concentrações elevadas de THMs em água tratada durante os processos de tratamento e na distribuição (CETESB, 2003).

O Cryptosporidium sp é medido em cocistos/L e a Giardia sp em cistos/L. As doenças parasitárias representam uma parcela significante de casos de morbidade e mortalidade e, a Giárdia lamblia e Cryptosporidium parvum estão entre os protozoários capazes de causar diarréias graves tanto em indivíduos imunocompetentes quanto imunodeficientes. A partir da década de 80, a preocupação com estes protozoários aumentou principalmente em relação aos casos de criptosporidiose. Dentre os vários modos de transmissão destas duas protozooses, a veiculação hídrica tem sido considerada a mais importante. Nos Estados Unidos, o "Federal Register" estabelece para essas águas um limite máximo de 10 cistos por litro de água bruta. Os coliformes termotolerantes podem não ser bons indicadores da presença destes protozoários. Outro importante aspecto que justifica a avaliação dos protozoários em águas reside no fato de que estes não são eliminados pela ação do cloro (CETESB, 2003).

Foram eleitos os meses de janeiro a março, no período de chuvas, e julho a outubro, no período de estiagem, para a obtenção de dados dos parâmetros selecionados.

O monitoramento realizado pela rede estadual da CETESB, ao longo dos anos, apresenta algumas variações e, eventualmente, inconstâncias. Para o período de 1978 a 1989, as análises da rede eram realizadas mensalmente (uma amostra por mês). A partir desse ano, elas passaram a ser bimensais (uma amostra a cada dois meses). Quando foi possível obter a média entre os meses eleitos, isso foi feito. $\mathrm{Na}$ análise de alguns parâmetros ou índice foi utilizada toda a série de dados ao longo do período de monitoramento. 


\section{RESULTADOS E DISCUSSÃO}

\subsection{Custo do tratamento de água $\mathrm{x}$ cobertura florestal da bacia}

5.1.1 Custos operacional das 7 ETAs/captações, qualidade dos mananciais e geração de lodo nas ETAs

O resultado dos custos específicos obtidos para as 7 ETAs está expresso no Quadro 28. Foram construídos ainda o Quadro 30 referente à qualidade dos parâmetros Turbidez e Oxigênio Dissolvido e o Quadro 31 referente à geração de lodo nas ETAs. 


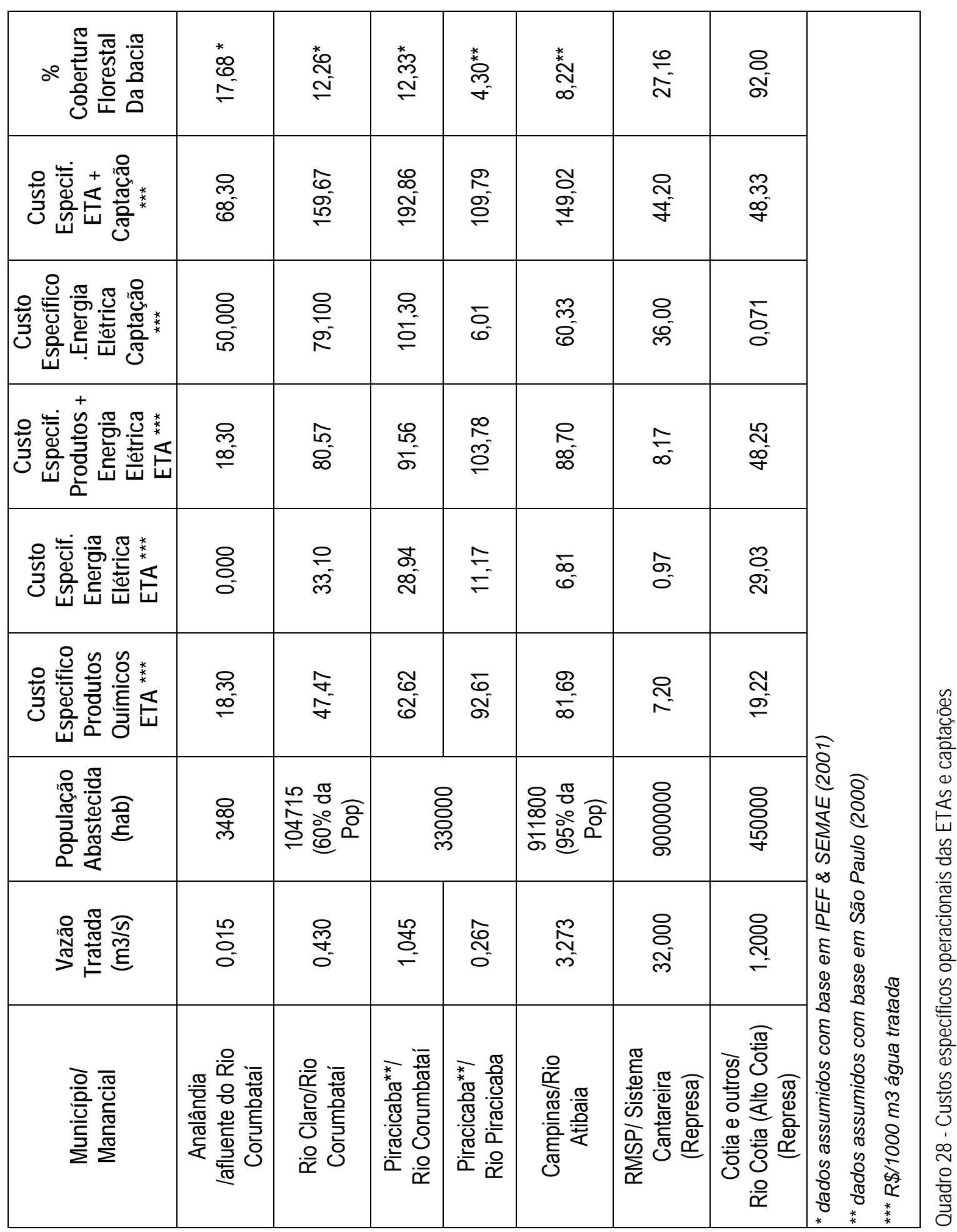


Do Quadro 28 que resume os custos específicos dos sistemas estudado depreende-se que :

\section{a) Quanto à Cobertura florestal x Custo específico de produtos}

químicos nas ETAs - A hierarquização dos sistemas em termos de cobertura florestal obedece à ordenação muito similar àquela considerada para o custo específico resultante da aplicação de produtos químicos. O Sistema Cantareira tem o segundo maior percentual de cobertura florestal das unidades estudadas e o menor custo de uso específico de produtos químicos; o rio Piracicaba tem o menor percentual de cobertura florestal das unidades estudadas e o maior custo de uso específico de produtos químicos. Curiosamente, exatamente o rio Piracicaba vem sofrendo com a perda de qualidade de suas águas, situação agravada pela redução da vazão liberada pelo Sistema Cantareira para a bacia do Piracicaba, principalmente no período de estiagem, o que contribui também com a elevação do custo do tratamento de suas águas para abastecimento público. O tratamento das águas do rio Piracicaba, incluindo-se custo com produtos químicos e energia elétrica da ETA, tem custo específico, para cada $1000 \mathrm{~m}^{3}$ de água tratada, 12,7 vezes superior ao tratamento das águas do Sistema Cantareira

Sabe-se que as bacias com maior percentual de cobertura florestal possuem menor interferência antrópica e que portanto, em geral, não estão submetidas à mesma carga de esgotos urbanos ou industriais, ou ao mesmo volume de materiais provenientes da erosão dos solos. Mas este confronto pretende mostrar a importância da manutenção de florestas em mananciais de abastecimento público, alertando que a cobertura florestal possui papel relevante sobre a proteção da qualidade dos recursos hídricos e que sua supressão implica em maiores custos sociais, seja pelo aumento do custo de tratamento das águas, seja pelo aumento dos riscos à saúde.

O Quadro 29 mostra a hierarquização do percentual de cobertura florestal e do custo específico de produtos químicos para todas as unidades de estudo. 


\begin{tabular}{|c|c|c|c|c|}
\hline $\begin{array}{c}\text { Municípiol } \\
\text { Manancial }\end{array}$ & $\begin{array}{c}\text { Custo } \\
\text { Especifico } \\
\text { Produtos } \\
\text { Químicos } \\
\text { ETA *** }\end{array}$ & $\begin{array}{c}\text { Hierarquia } \\
\text { do custo } \\
\text { de } \\
\text { produtos } \\
\text { químicos }\end{array}$ & $\begin{array}{c}\% \\
\text { Cobertura } \\
\text { Florestal } \\
\text { Da bacia }\end{array}$ & $\begin{array}{c}\text { Hierarquia } \\
\text { do \% de } \\
\text { cobertura } \\
\text { florestal }\end{array}$ \\
\hline $\begin{array}{c}\text { Analândia } \\
\text { lafluente do Rio } \\
\text { Corumbataí }\end{array}$ & 18,30 & $2^{\circ}$ & 17,68 & $3^{\circ}$ \\
\hline $\begin{array}{c}\text { Rio Claro/Rio } \\
\text { Corumbataí }\end{array}$ & 47,47 & $4^{\circ}$ & 12,26 & $5^{\circ}$ \\
\hline $\begin{array}{c}\text { Piracicaba**/ } \\
\text { Rio Corumbataí }\end{array}$ & 62,62 & $5^{\circ}$ & 12,33 & $4^{\circ}$ \\
\hline $\begin{array}{c}\text { Piracicaba**/ } \\
\text { Rio Piracicaba }\end{array}$ & 92,61 & $7^{0}$ & 4,30 & $7^{0}$ \\
\hline $\begin{array}{c}\text { Campinas/Rio } \\
\text { Atibaia }\end{array}$ & 81,69 & $6^{\circ}$ & 8,22 & $6^{\circ}$ \\
\hline $\begin{array}{c}\text { RMSP/ Sistema } \\
\text { Cantareira } \\
\text { (Represa) }\end{array}$ & 7,20 & $1^{0}$ & 27,16 & $2^{\circ}$ \\
\hline $\begin{array}{c}\text { Cotia e outros/ } \\
\text { Rio Cotia (Alto Cotia) } \\
\text { (Represa) }\end{array}$ & 19,22 & $3^{\circ}$ & 92 & $1^{0}$ \\
\hline
\end{tabular}

*** $R \$ / 1000 \mathrm{m3}$ água tratada

Quadro 29- Hierarquização do percentual de cobertura florestal e do custo específico de produtos químicos

Observando-se o Quadro 29 as três unidades que possuem custos específicos de produtos químicos mais baixos, inferiores a $\mathrm{R} \$ 20,00 / 1000 \mathrm{~m}^{3}$ de água tratada, são aquelas que possuem maiores índices de cobertura florestal e todos superiores a $15 \%$. As duas unidades que possuem os menores percentuais de cobertura florestal, ambos abaixo de $10 \%$, apresentam os mais altos custos específicos de produtos químicos. A Figura 33 mostra o comportamento refletido no Quadro 29. 


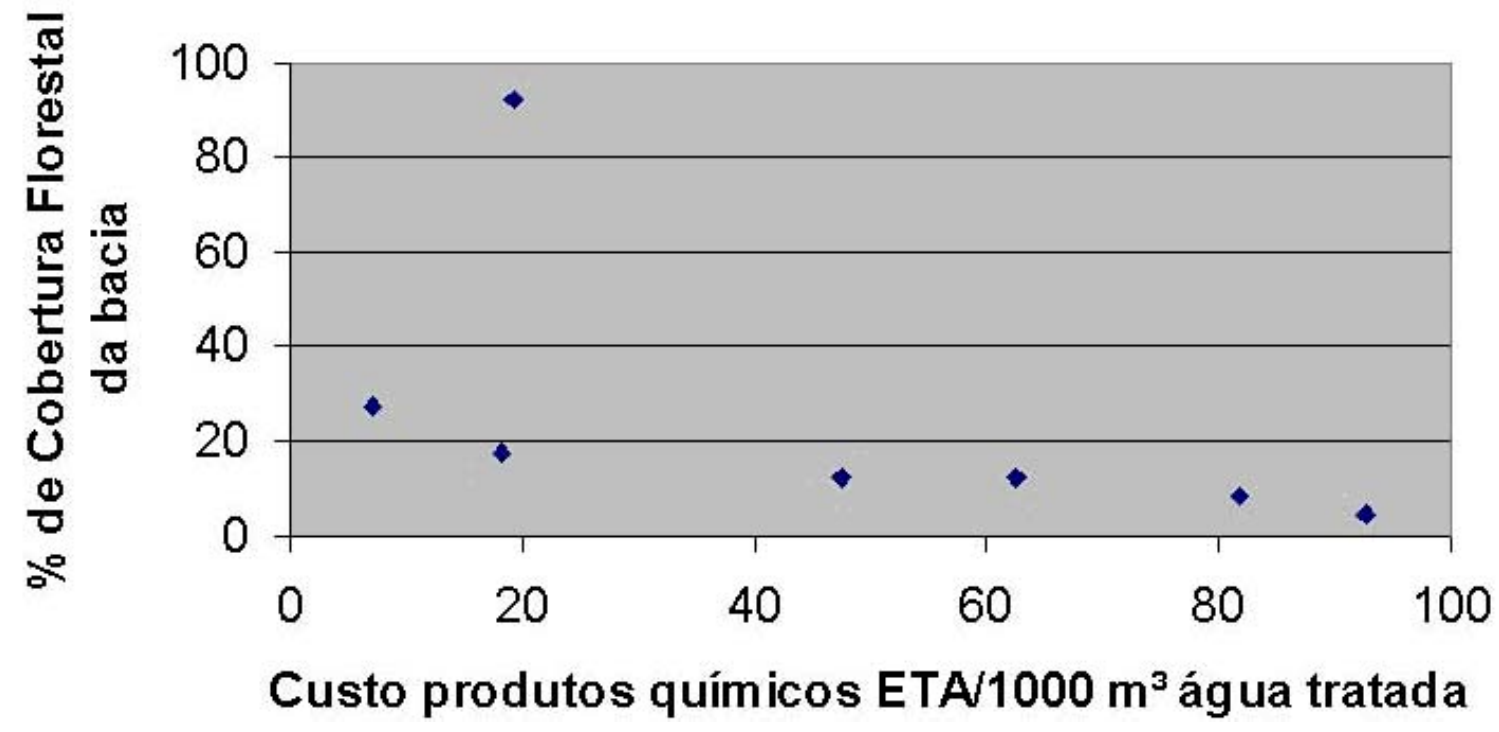

Figura 33 -Relação entre \% de cobertura florestal e custo com consumo de produtos químicos para cada $1000 \mathrm{~m}^{3}$ de água tratada.

b) Quanto ao custo específico de energia elétrica na ETA - O gasto da energia elétrica na ETA está associado, dentre outros fatores, ao número de operações executadas na estação, o que inclui principalmente a freqüência de lavagem de filtros e decantadores, em decorrência de maior deposição de sólidos nas unidades de tratamento. Tendo em vista a particularidade desta operação para cada estação, pouco se pode inferir a partir dos resultados obtidos. No entanto, à exceção da ETA de Analândia, que declarou não ter custos com energia elétrica, e da ETA de Cotia, que apresenta um alto consumo de energia, os demais resultados podem sugerir que as duas ETAs situadas no rio Corumbataí tenham este custo potencializado pela maior migração de sólidos para os corpos hídricos em razão das características do meio físico. Segundo Ferraz (2002), a maior taxa de perda de solo determinada em seu estudo da bacia hidrográfica do rio Piracicaba foi para a bacia do rio Corumbataí e a menor para a bacia do rio Atibaia. Tal resultado exprime o contexto geológicogeomorfológico-pedológico em que a bacia do Corumbataí se insere. Ou seja, um arcabouço natural extremamente suscetível a erosão e capaz de fornecer grandes quantidades de materiais das encostas para os cursos d'água, conforme se discute no item correspondente a caracterização do meio físico. 


\section{c) Quanto ao custo específico da energia elétrica na captação de} água - As situações constatadas devem estar repletas de particularidades, permitindo pouca inferência sobre as situações. Entretanto, no caso do abastecimento do município de Piracicaba, comparando-se os custos de captação entre as realizadas nos rios Piracicaba e Corumbataí, observa-se que o distanciamento do manancial, da população servida, elevou o custo de $R \$ 6,01 / 1000 \mathrm{~m}^{3}$ de água tratada para $R \$ 101,00 / 1000 \mathrm{~m}^{3}$ de água tratada. Neste caso, a perda do rio Piracicaba como principal manancial de abastecimento público representou o encarecimento do custo da água, situação que onerou o poder público e consequentemente seus usuários.

d) Quanto ao custo específico final de tratamento da água - Os sistemas de captação/tratamento das águas do rio Corumbataí, para as unidades de Piracicaba e Rio Claro, possuem os custo específicos mais altos dentre todos os mananciais estudados. O sistema de Campinas no rio Atibaia possui o terceiro custo específico mais elevado dentre as unidades estudadas, seguido pelo sistema do rio Piracicaba. Os sistemas que se utilizam dos mananciais que têm percentual de cobertura florestal superior a $15 \%$ têm os menores custos específicos totais. No entanto, a relação do percentual de cobertura florestal com o custo específico total não apresenta regularidade como a obtida com o custo específico pelo uso de produtos químicos.

Os resultados sobre os custos de tratamento das águas demonstraram que mesmo a sofisticação e o encarecimento do tratamento das águas do rio Piracicaba, o que inclui a adição sistemática de carvão ativado, não foram suficientes para mantê-lo como principal manancial de abastecimento público do município de Piracicaba. Este fato é de extrema relevância e enaltece a conviç̧ão de que são necessárias outras intervenções na bacia, além da somatória de processos físicos e químicos para se obter água para abastecimento público de qualidade.

O Quadro 30 agrega os valores dos sistemas estudados referentes à qualidade de seus mananciais. 


\begin{tabular}{|c|c|c|c|c|c|c|c|c|}
\hline 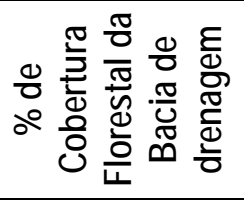 & 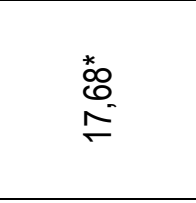 & 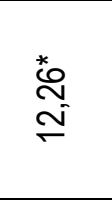 & 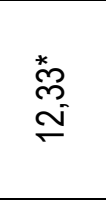 & 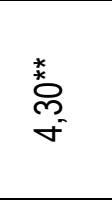 & $\begin{array}{l}\stackrel{*}{*} \\
\underset{\infty}{*} \\
\infty\end{array}$ & $\frac{0}{\tilde{N}}$ & శూ & \\
\hline 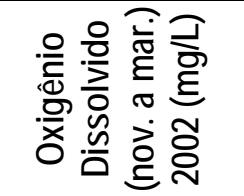 & $\begin{array}{l}\text { क् } \\
0\end{array}$ & $\bar{\sigma}$ & $\begin{array}{l}\infty \\
\infty^{\infty}\end{array}$ & $\stackrel{\infty}{m}$ & 으 & $\overline{6}$ & $\stackrel{\sim}{\infty}$ & \\
\hline 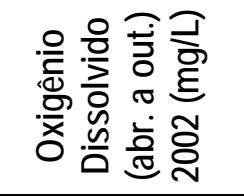 & 足 & $\stackrel{\leftrightarrow}{N}$ & $\begin{array}{l}\circ \\
0^{\circ}\end{array}$ & $\stackrel{\Omega}{=}$ & in & $\underset{\forall}{\sim}$ & $\bar{\infty}$ & \\
\hline 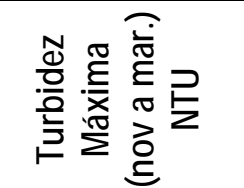 & $\stackrel{2}{\sim}$ & $\begin{array}{l}\infty \\
\infty \\
\infty\end{array}$ & $\stackrel{\infty}{\frac{\infty}{\gamma}}$ & 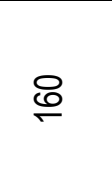 & 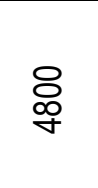 & ஜ్లి & 으 & \\
\hline 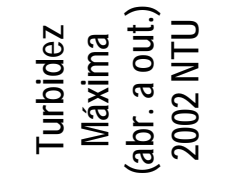 & $\mathscr{N}$ & 옹 & $\stackrel{\text { ஸొ }}{\text { }}$ & $\stackrel{8}{q}$ & ర్లి & శూ & $m$ & \\
\hline 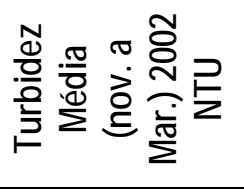 & $\widetilde{N}$ & $\stackrel{\mathscr{N}}{\sim}$ & 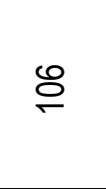 & ঠ & 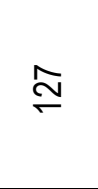 & $a$ & $\infty$ & 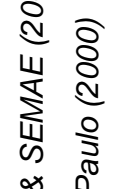 \\
\hline 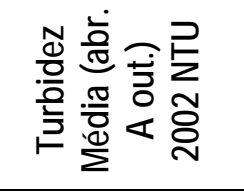 & $\stackrel{\infty}{\leftarrow}$ & $\hat{m}$ & 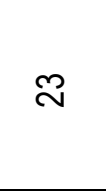 & $\stackrel{\bullet}{\circ}$ & ిల & $m$ & 10 & 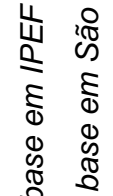 \\
\hline 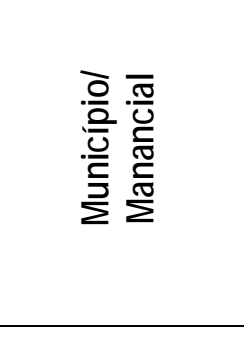 & 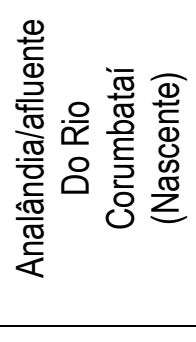 & 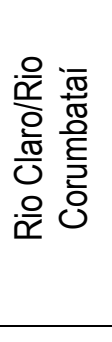 & 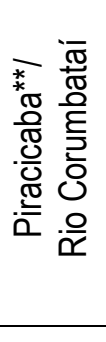 & 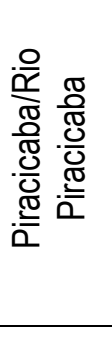 & 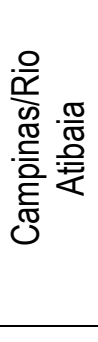 & 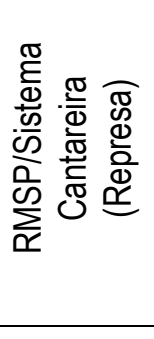 & 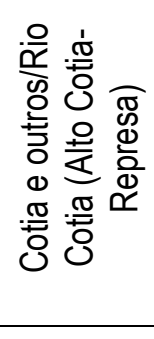 & 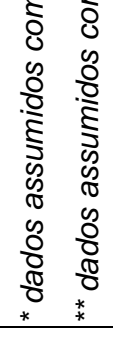 \\
\hline
\end{tabular}


Do Quadro 30, que resume a qualidade dos mananciais dos sistemas estudados, depreende-se que :

- Os mananciais que apresentam maior variação na turbidez média, entre a estação chuvosa e a estiagem, são aqueles que possuem índices de cobertura florestal inferiores a 15\%. A Figura 34 demonstra o comportamento dos mananciais estudados, mostrando maior estabilidade da qualidade das águas nas bacias com maior percentual de cobertura florestal. Ressalta-se que grandes variações na turbidez causam transtorno à operação da ETA e implicam no maior consumo de produtos químicos, aumentando o custo operacional e susceptibilidade do tratamento.

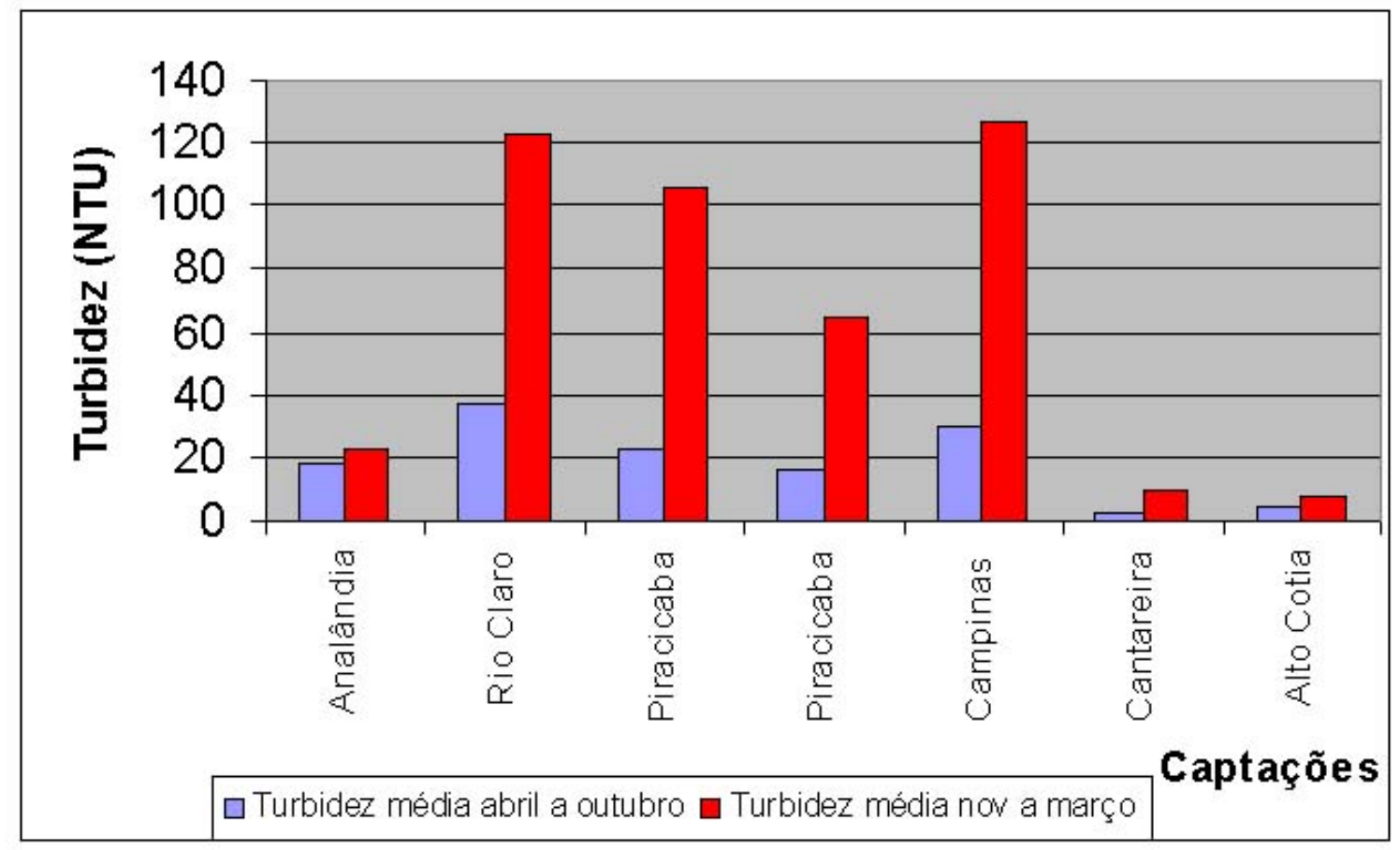

Figura 34 -Turbidez nos períodos de estiagem e chuvas nos 7 mananciais estudados para o ano 2002

- As calhas dos rios Corumbataí e Atibaia apresentam os mais altos valores médios de turbidez nos dois períodos, de seca e estiagem. O rio Atibaia tem registros elevadíssimos de turbidez máxima na estação seca e no período chuvoso, que ultrapassam a casa das 2.000 NTU, mostrando que há fortes interferências do meio refletindo-se na qualidade de suas águas. A elevação da 
turbidez representa movimentação de sólidos nas calhas do rios, provável deposição parcial destes sólidos e assoreamento gradual da calha.

- As calhas dos rios Piracicaba e Atibaia são mais susceptíveis a variações de OD, influenciadas também pela operação de vazões do Sistema Cantareira. O único manancial que apresentou variação significativa do Oxigênio Dissolvido nos dois períodos foi o rio Piracicaba, mostrando a ausência de qualidade do manancial devido a todas as contribuições que a bacia recebe a montante da captação de Piracicaba.

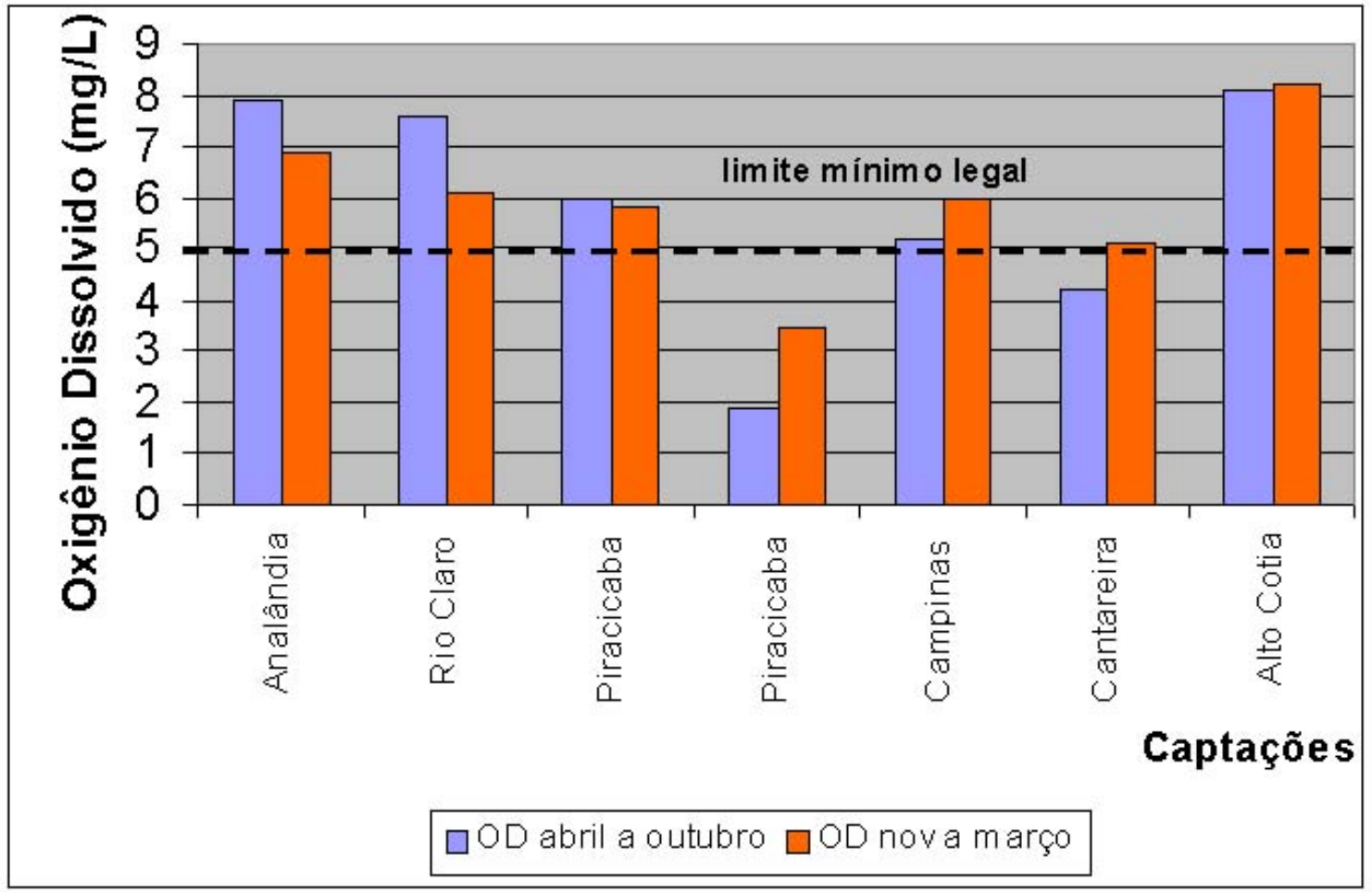

Figura 35- -Oxigênio Dissolvido nos períodos de estiagem e chuvas nos 7 mananciais estudados para o ano 2002 


\begin{tabular}{|c|c|c|c|c|c|c|c|c|}
\hline 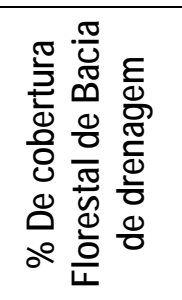 & $\begin{array}{l}\text { *o } \\
\stackrel{\infty}{0} \\
\stackrel{5}{=}\end{array}$ & $\begin{array}{l}\stackrel{*}{\sim} \\
\underset{\sim}{\sim}\end{array}$ & $\stackrel{\text { * }}{\stackrel{m}{\sim}}$ & \begin{tabular}{l} 
* \\
\multirow{2}{*}{} \\
$\stackrel{p}{+}$
\end{tabular} & $\begin{array}{l}\underset{*}{*} \\
\underset{\infty}{*}\end{array}$ & $\frac{\varrho}{\approx}$ & శั & \\
\hline 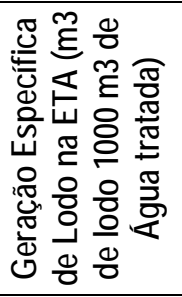 & 8 & $\stackrel{R}{=}$ & $\stackrel{8}{-}$ & ' & $\bar{\sigma}$ & O̊ & ऽ̊ & \\
\hline 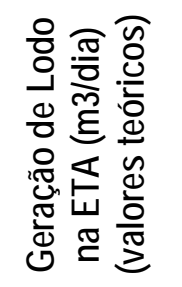 & 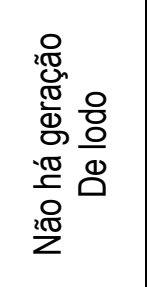 & $\begin{array}{l}m \\
\infty^{\circ}\end{array}$ & ๙ิ & ' & $\underset{\infty}{ \pm}$ & $\begin{array}{l}0^{0} \\
\infty \\
\infty\end{array}$ & $\stackrel{m}{\sim}$ & \\
\hline 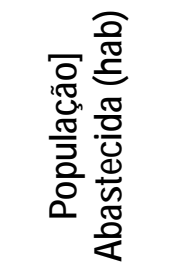 & $\begin{array}{l}\text { ০ } \\
\text { ডે }\end{array}$ & 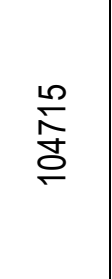 & ষ্ণি & ' & $\begin{array}{l}\frac{8}{\circ} \\
\frac{\infty}{\sigma}\end{array}$ & ஓి & $\begin{array}{l}8 \\
8 \\
8 \\
\qquad \\
\qquad\end{array}$ & 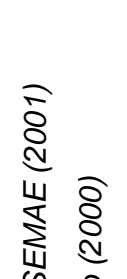 \\
\hline 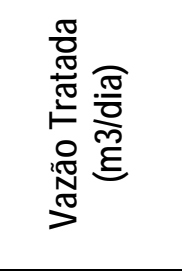 & 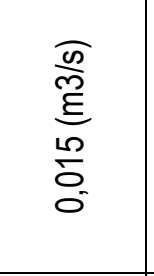 & 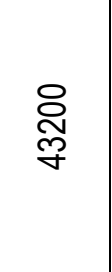 & 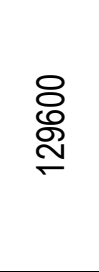 & ' & $\underset{\substack{\infty \\
\stackrel{\infty}{\sim}}}{\stackrel{\sim}{\sim}}$ & 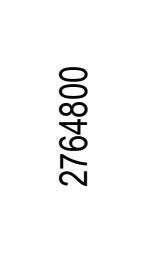 & $\begin{array}{l}\circ \\
\& 0 \\
\mathbb{0} \\
\text { ᄋ }\end{array}$ & 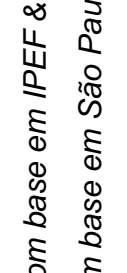 \\
\hline 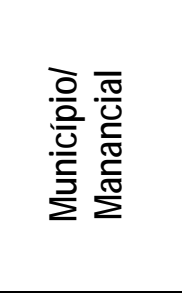 & 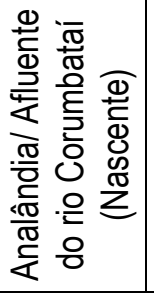 & 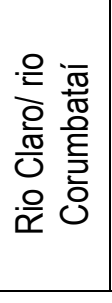 & 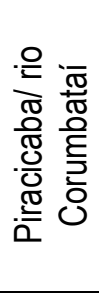 & 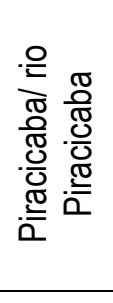 & 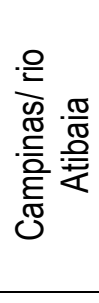 & 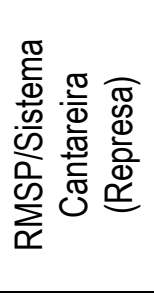 & 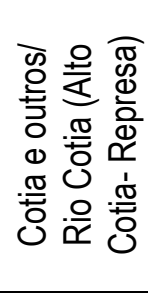 & 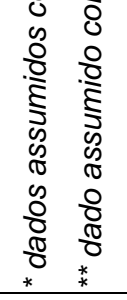 \\
\hline
\end{tabular}


Do Quadro 31, que lista a geração de lodo nas ETAs dos sistemas estudados, depreende-se que :

- As duas ETAs convencionais situadas no rio Corumbataí, a do município de Rio Claro, no Médio Corumbataí e a do município de Piracicaba, no Baixo Corumbataí, são as maiores geradoras de lodo dentre todas as estudadas, excetuando-se a de Analândia, que não utiliza sistema convencional de tratamento e não gera lodo. Se observada a turbidez média de novembro a março, época chuvosa, para o ano de 2002, com valores compilados no Quadro 30 , observa-se que os maiores valores de turbidez ocorrem no rio Atibaia, em Campinas, no rio Corumbataí, em Rio Claro e no rio Corumbataí em Piracicaba. Os demais sistemas estudados, com percentual de cobertura floresta superior a $15 \%$, apresentam volume específico de lodo gerado ente 0,00 e 0,03 $\mathrm{m}^{3}$ de lodo/1000 $\mathrm{m}^{3}$ de água tratada.

- A geração excessiva de lodo é extremamente desinteressante, já que quanto maior seu volume pelo menos três são os fatores incrementados: maior será a capacidade das instalações da estação de tratamento de lodo, mais energia e produtos químicos serão gastos para desidratá-lo e maior será o gasto com transporte e destinação do material sólido proveniente da estação de tratamento de lodo. Ressalta-se mais uma vez que não foi possível computar esta parcela de custo no cálculo do custo final do tratamento de água. Mas, certamente, diante dos resultados obtidos no Quadro 28 os sistemas de Rio Claro e Piracicaba (Capim Fino) no rio Corumbataí que apresentaram os custos mais altos de tratamento de água seriam incrementados pelos custos decorrentes do volume de lodo a ser desidratado, transportado e adequadamente disposto.

- O volume de lodo gerado nas ETAs pode servir ainda como indicador da perda de solo que a bacia vem sofrendo em função da ausência de planejamento e do uso do solo inapropriado.

- Conforme extensamente relatado no Capítulo Revisão de Literatura, o risco à saúde humana, agudo ou crônico, está associado à qualidade da fonte de água de abastecimento e à qualidade da água tratada. A maior taxa específica de geração de lodo demonstra que está havendo maior migração de sólidos para a ETA e um volume proporcional de produtos químicos deve ser utilizado, favorecendo à possibilidade de formação, por exemplo, de subprodutos da 
desinfecção (DBPs). No município de Piracicaba, quando suas águas para abastecimento público provinham principalmente do rio Piracicaba, eram freqüentes as queixas da população sobre a presença de gosto e odor na água tratada, considerados subprodutos da desinfecção (DBPs). Com a mudança do manancial principal para o rio Corumbataí, este problema foi bastante minimizado. A presença de atividades industriais, rurais e de centros urbanos expressivos nos mananciais aqui estudados dos rios Corumbataí, Atibaia e Piracicaba potencializa o problema relacionado também aos compostos organoclorados leves (clorofórmio, por exemplo) ou Trialometanos. O volume de lodo gerado em uma ETA está relacionado com a fragilidade do meio físico, mas também com a presença de atividades industriais, rurais e urbanas que potencializam os riscos à saúde associados a um determinado manancial de abastecimento.

As bacias com percentuais de cobertura florestal superiores a $15 \%$ apresentaram os menores índices de geração de lodo nas ETAs. Este fato mostra a importância da cobertura florestal em mananciais de abastecimento público, minimizando os riscos à saúde pública. O volume específico de lodo gerado em uma ETA pode servir-se ao papel de um dos indicadores das condições de manejo da bacia hidrográfica.

\subsection{Bacia do rio Piracicaba $\times$ Bacia do rio Corumbataí}

\subsubsection{Meio Físico, Uso e Ocupação do Solo e Disponibilidade Hídrica}

No que se refere ao meio físico, a bacia hidrográfica do rio Piracicaba tem praticamente todo seu alto curso no âmbito do Planalto Atlântico, com os trechos de médio e baixo cursos desenvolvendo-se na Depressão Periférica. De imediato têm-se, respectivamente, relevos de morros e serras com fortes declividades e solos rasos, contrapostos a relevos de colinas e morrotes com declividades mais suaves e solos mais espessos. Rompe esse padrão, porém apenas localmente, os divisores ocidentais da bacia do rio Corumbataí, que são definidos pelos relevos escarpados das Cuestas Basálticas. Essa compartimentação do relevo obedece a distribuição das rochas. No alto curso, domínio do Planalto Atlântico, ocorrem as rochas resistentes do 
embasamento cristalino, enquanto que em todo o trecho de jusante, domínio da Depressão Periférica, os depósitos de sedimentos variados que constituem o empilhamento de camadas da Bacia Sedimentar do Paraná (IPT, 1981a).

Em termos de erosão, tais contextos exprimem suscetibilidades naturais muito distintas. No Planalto Atlântico, os solos são predominantemente rasos e de maior erodibilidade e estão ligados a encostas de maior declive, do que resultam terrenos de potencialidades erosivas sempre altas a muito altas (IPT, 1981b).

No âmbito da Depressão Periférica, os relevos mais suaves de colinas e morrotes têm suscetibilidades erosivas que se diferenciam em função da constituição do substrato. De modo geral as suscetibilidades desse domínio são menos intensas que nos terrenos de morrarias e serranias do Planalto Atlântico. Na maior parte da Depressão Periférica predomina sedimentos argiloso-siltosos, que associados aos declives mais suaves de colinas e morrotes originam potencialidades erosivas naturais médias a baixas, com índices mais altos associados a variações do relevo ou então a presença de substrato arenítico. Em termos de expressão contínua em área, as maiores potencialidades erosivas cabem aos terrenos onde a presença de formações areníticas é mais notável, caso do domínio do baixo curso, principalmente da bacia do rio Corumbataí. Nessa região, circunvizinhos ocorrem os relevos de morros e escarpas ligados às Cuestas Basálticas, que em conjunto com os terrenos areníticos constituem a área de maior suscetibilidade erosiva no âmbito do médio e baixo cursos da bacia do rio Piracicaba (IPT, 1981b).

Em síntese, a tendência natural de produção de sedimentos nas encostas é muito maior nos terrenos cristalinos do Planalto Atlântico e areníticos da Depressão Periférica, em relação aos domínios de sedimentos finos do restante desta unidade geomorfológica. A modificação do escoamento pluvial, imposta por ocupação e uso das terras, incrementa tais potenciais naturais, pois de um escoamento em lençol e com alta tendência de infiltração em terrenos originalmente cobertos por vegetações nativas, passa a ser um escoamento concentrado com alta capacidade de desbaste e transporte dos solos, agora em terrenos destituídos da cobertura vegetal protetora. Genericamente pode-se estimar taxas de assoreamento dos cursos d'água muito mais elevadas nos domínios discriminados como de potenciais erosivos mais elevados.

O percentual de uso e ocupação do solo nas duas bacias é da mesma ordem de grandeza para os seguintes segmentos analisados (Quadro 32): culturas 
temporárias (cana-de-açúcar), pastagens e campos. São estes dois segmentos que interferem significativamente na qualidade das águas se mal manejados, e, salvo exceções, é o que ocorre em muitas das propriedades nas duas bacias. Esta semelhança espelha uma realidade de difíceis perspectivas para a bacia do rio Corumbataí, agravadas pela maior susceptibilidade à erosão dos solos desta bacia.

O percentual de ocupação pelas áreas urbanas está próximo da metade na bacia do rio Corumbataí frente à bacia do rio Piracicaba. A expansão urbana é um dos usos mais preocupantes em termos de conservação de recursos hídricos.

O percentual de cobertura florestal na bacia do rio Piracicaba é cerca de $1 / 3$ do que possui a bacia do rio Corumbataí. Sabe-se que a importância da cobertura florestal está associada a sua localização geográfica na bacia. O índice de 7,98 \% da cobertura florestal nativa está localizado nas APPs da bacia do rio Corumbataí. A totalidade das APPs da bacia do rio Corumbataí por outro lado está ocupada por diversos usos, dentre os quais 56,49 \% destina-se à pastagem e apenas 25,84 \% refere-se à floresta nativa. Ou seja, a bacia está com sua capacidade de filtração das águas de drenagem bastante prejudicada.

A regulamentação da APA Corumbataí - Botucatu - Tejupá , cujos limites estão demarcados na Figura 36, pode ser um dos instrumentos importantes para favorecer a reversão do quadro de degradação em evolução na bacia do rio Corumbataí. Dos 6 municípios pertencentes à UGRHI 05 da bacia do rio Corumbataí, apenas os municípios de Piracicaba e de Santa Gertrudes não possuem área incluída na APA. No entanto, o processo de regulamentação está parado na Assembléia Legislativa do Estado de São Paulo e desconhece-se que seja este um projeto prioritário para essa casa ou para o Estado. Sabe-se que os municípios que possuem a totalidade de suas áreas ou parte delas dentro da APA possuem restrições ao projeto, por entenderem que a vigência da APA pode vir a bloquear seu desenvolvimento econômico. De fato, entende-se que o Estado não dispõe de projetos conjugados que possam minimizar os possíveis efeitos do estabelecimento de restrições quanto à ocupação dessas áreas nos municípios afetados. 


\begin{tabular}{|c|c|c|c|c|c|c|}
\hline Bacia & $\begin{array}{c}\text { Culturas } \\
\text { Temporárias } \\
(\%)\end{array}$ & $\begin{array}{c}\text { Culturas } \\
\text { Perenes } \\
(\%)\end{array}$ & $\begin{array}{l}\text { Cobertura } \\
\text { Florestal } \\
\text { Nativa } \\
(\%)\end{array}$ & $\begin{array}{c}\text { Reflorestamento } \\
\text { (\%) }\end{array}$ & $\begin{array}{c}\text { Pastagens } \\
\text { e campos } \\
(\%)\end{array}$ & $\begin{array}{c}\text { Áreas } \\
\text { urbanas e } \\
\text { industriais } \\
(\%)\end{array}$ \\
\hline $\begin{array}{c}\text { Corumbataí } \\
\text { (IPEF\&SEMAE, } \\
\text { 2001) } \\
\end{array}$ & 25,57 & 2,82 & 12,36 & 7,33 & 43,68 & 2,77 \\
\hline $\begin{array}{c}\text { Corumbataí } \\
\text { (CBH-PCJ, } \\
2000)\end{array}$ & 22,05 & 2,10 & 7,45 & 5,18 & 60,8 & 2,43 \\
\hline $\begin{array}{c}\text { Piracicaba } \\
\text { (CBH-PCJ, } \\
2000)\end{array}$ & 37,47 & 5,57 & 4,30 & 0,95 & 45,65 & 6,10 \\
\hline \multicolumn{7}{|c|}{ Obs: Os dados referem-se apenas à área da bacia situada no Estado de São Paulo. } \\
\hline \multicolumn{7}{|c|}{$\begin{array}{l}\text { Obs: A cana-de-açúcar está inserida em culturas temporárias, apesar de não relatado na fonte de } \\
\text { pesquisa. }\end{array}$} \\
\hline
\end{tabular}

Quadro 32 - Uso e Ocupação do solo nas bacias do rio Piracicaba e Corumbataí

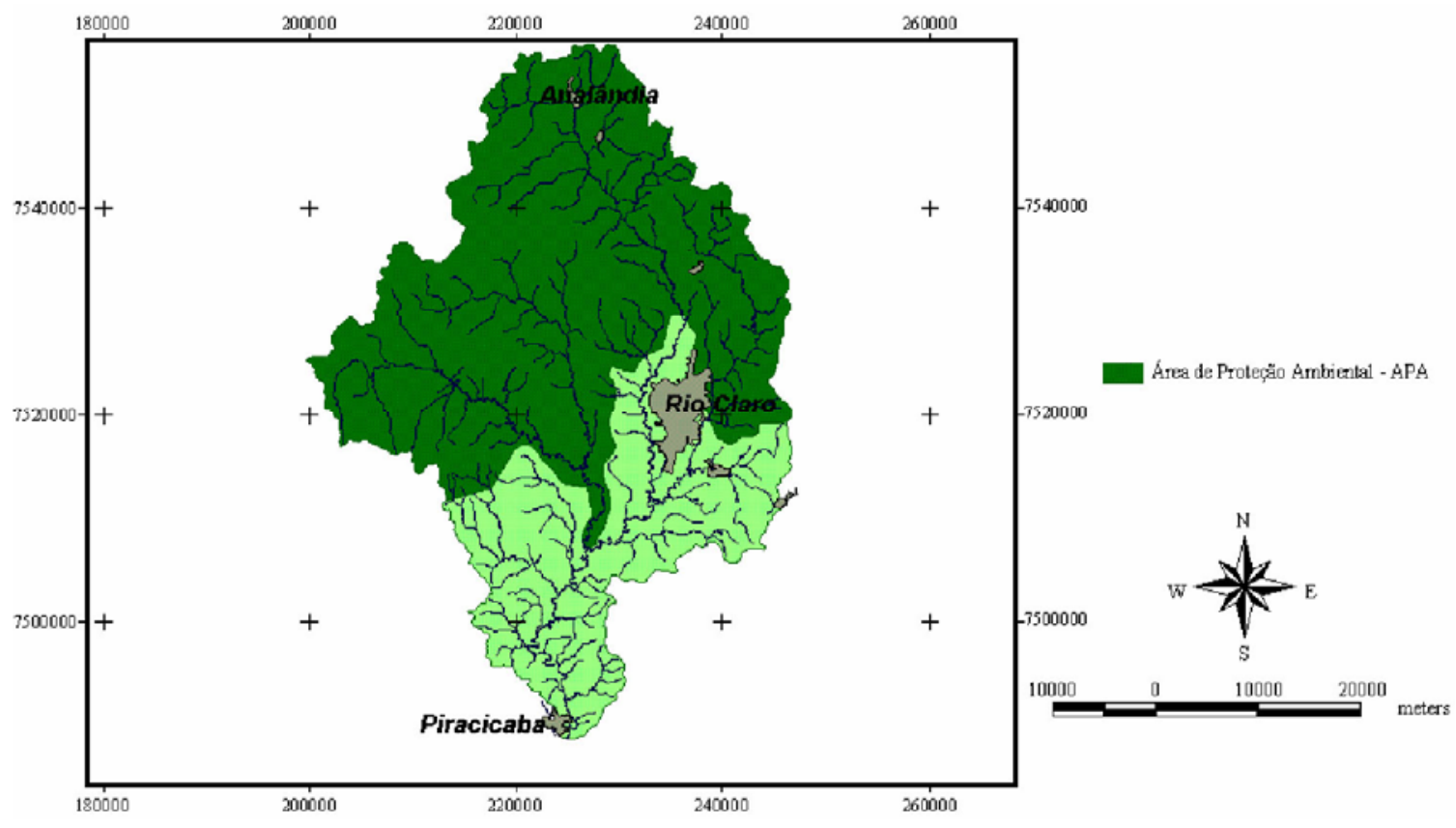

Figura 36 - Limites do perímetro da APA Corumbataí-Botucatu-Tejupá na Bacia do Rio Corumbataí. Fonte: IPEF\&SEMAE (2001).

A relação demanda/disponibilidade hídrica exposta no Quadro 33 para a bacia do rio Piracicaba, no ano 2000, para Q 7,10 era já de $112,5 \%$, ou seja, 
considerando-se a vazão mínima dos rios, a bacia do rio Piracicaba, com todos os seu afluentes e formadores, inclusive o rio Corumbataí , já está com demanda maior do que a disponibilidade. Para a vazão Q 95\%, em 2010, a projeção para a vazão que registrase em $95 \%$ do tempo atinge quase os $100 \%$, ou seja, toda a disponibilidade seria consumida pela demanda de água. Estes dados indicam altos índices de reuso e avançado estado de degradação dos recursos hídricos.

A relação demanda/disponibilidade hídrica exposta no Quadro 33 para a bacia do rio Corumbataí, no ano 2000, para Q 7,10 era de 76,7 \% e para Q 95\% era de 45,6 \%. A fonte IPEF\&SEMAE (2001) apresenta outro dado com relação à demanda/disponibilidade hídrica para Q7,10 de 88 \%. Seja qual for o dado mais próximo da realidade, a situação é preocupante e com ordem de grandeza próxima ao que ocorre na bacia do rio Piracicaba.

O maior uso de água na bacia do rio Corumbataí, 60,19 \%, refere-se ao abastecimento doméstico. As taxas geométricas anuais de crescimento da população total nos municípios da bacia do rio Corumbataí são superiores à média da mesma taxa para a Região Administrativa de Campinas. O rio Corumbataí abastece 7 municípios da bacia e alguns afluentes como o rio Passa Cinco são considerados mananciais estratégicos para os municípios de Piracicaba, Rio Claro e Santa Gertrudes. A partir desses fatos pode-se inferir que as perspectivas de uso do rio Corumbataí como manancial de qualidade não são otimistas. As projeções, conforme Quadro 33 mostram que no ano 2020, em 95 \% do tempo, 55\% da disponibilidade hídrica estará comprometida.

\begin{tabular}{|c|c|c|c|c|c|c|c|c|}
\hline & \multicolumn{6}{|c|}{ Demanda/Disponibilidade Hídrica (\%) } \\
\hline \multirow{2}{*}{ Bacia } & \multicolumn{2}{|c|}{$\mathbf{2 0 0 0}$} & \multicolumn{2}{c|}{$\mathbf{2 0 0 5}$} & \multicolumn{2}{c|}{$\mathbf{2 0 1 0}$} & \multicolumn{2}{c|}{$\mathbf{2 0 2 0}$} \\
\cline { 2 - 9 } & $\mathrm{Q} 7,10$ & $\mathrm{Q} 95 \%$ & $\mathrm{Q} 7,10$ & $\mathrm{Q} 95 \%$ & $\mathrm{Q} 7,10$ & $\mathrm{Q} 95 \%$ & $\mathrm{Q} 7,10$ & $\mathrm{Q} 95 \%$ \\
\hline Corumbataí & 76,7 & 45,6 & 82,0 & 48,8 & 87,2 & 51,9 & 92,7 & 55,2 \\
\hline $\begin{array}{c}\text { Piracicaba } \\
\text { (Incluindo todas } \\
\text { sub-bacias) }\end{array}$ & 112,5 & 75,2 & 120,2 & 80,3 & 128,2 & 85,7 & 142,0 & 94,9 \\
\hline
\end{tabular}

Quadro 33 - Relações entre Demanda e Disponibilidade dos recursos hídricos nas bacias dos rios Piracicaba e Corumbataí

Fonte: Adaptado de São Paulo (2000) 


\subsubsection{Demografia}

A análise da evolução do comportamento do crescimento da população total nas bacias hidrográficas dos rios Piracicaba e Corumbataí obedeceu à organização descrita no item

As Figuras 37 e 38 reúnem de forma gráfica as taxas geométricas médias de crescimento da população total para os três períodos estudados, de acordo com as faixas de divisão populacional estabelecidas no item 3 deste Capítulo 1, para as duas unidades de estudo.

Bacia do rio Piracicaba

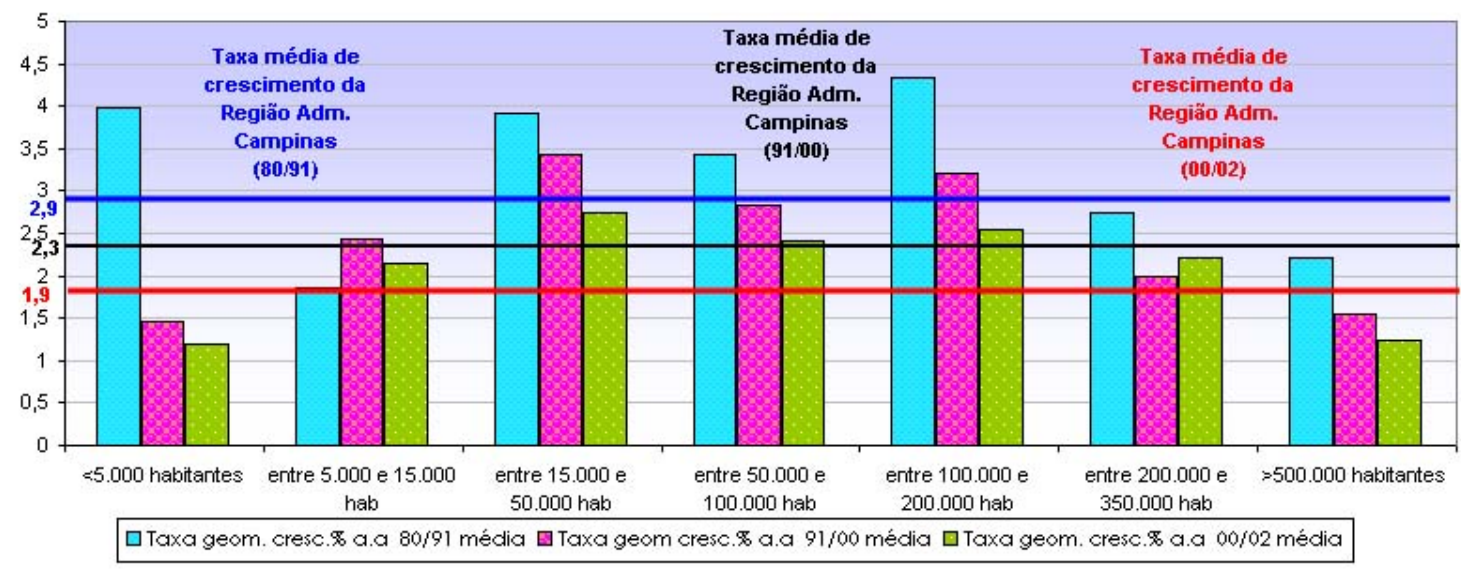

Figura 37 - Taxas geométricas médias de crescimento anual da população total para os três períodos estudados, por classes de municípios, para a bacia do rio Piracicaba.

Na bacia do rio Piracicaba, da Figura 37 observa-se que as taxas geométricas médias de crescimento anual da população para a maioria das classes de municípios, para o período mais recentemente medido de 2000 a 2002, são superiores à taxa média de crescimento da Região Administrativa de Campinas. As exceções neste caso referem-se às classes de municípios < 5.000 hab. e > 500.000 hab., esta que engloba apenas o município de Campinas. Este resultado demonstra a manutenção de crescimento demográfico médio dos municípios da bacia do rio Piracicaba acima de valores médios registrados para a região, ainda que inferiores às médias das taxas obtidas para a região entre 80/91 e 91/00. A redução da taxa média anual de crescimento da Região Administrativa de Campinas, que expressa uma queda na 
velocidade de crescimento da região, não torna a situação menos preocupante, uma vez que a capacidade do meio e particularmente dos recursos hídricos já se encontra bastante comprometida.

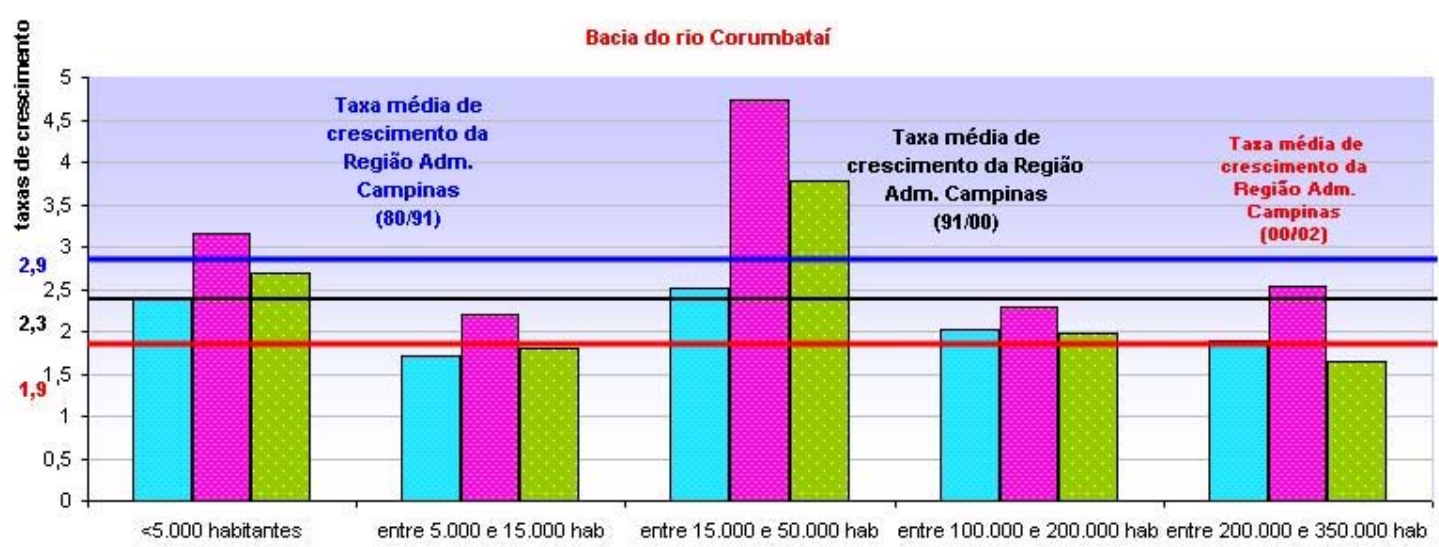

classes de municípios

口Taxa geom. cresc. \% a. a 80/91 média $\quad$ GTaxa geom cresc. $\%$ a. a $91 / 00$ média

口Taxa geom. cresc. \% a.a 00/02 média

Figura 38 - Taxas geométricas médias de crescimento anual da população total para os três períodos estudados, por classes de municípios, para a bacia do rio Corumbataí.

Da Figura 38 conclui-se que apenas o município de Piracicaba, representante da classe de municípios na bacia do rio Corumbataí entre 200.000 e 350.000 hab., possui taxa geométrica média de crescimento anual da população total inferior à taxa de mesma grandeza registrada para a Região Administrativa de Campinas. Este resultado demonstra a manutenção de crescimento demográfico médio dos municípios da bacia do rio Corumbataí acima de valores médios registrados para a região, ainda que inferiores às médias das taxas obtidas para a região entre 80/91 e 91/00.

A Figura 39 reúne de forma gráfica as taxas geométricas médias de crescimento da população total para os três períodos estudados, para as duas unidades de estudo, sem considerar divisão de municípios por faixa populacional. 


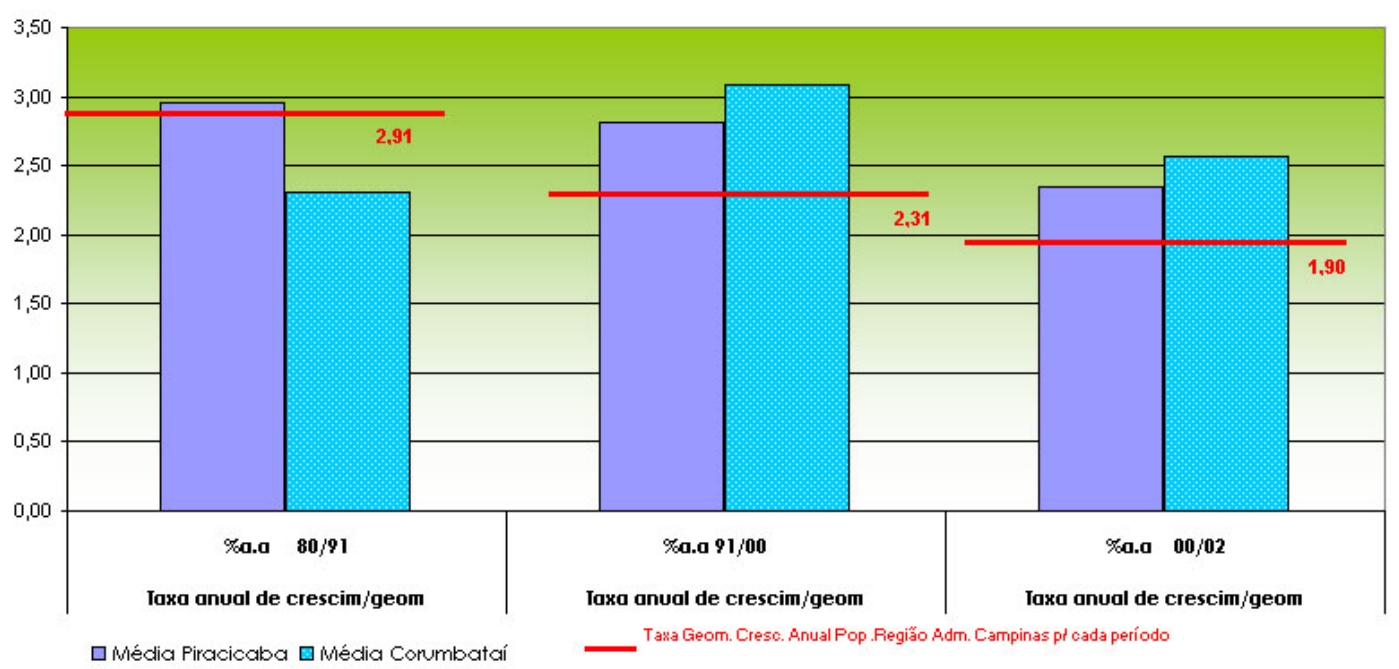

Figura 39 - Comparação das taxas geométricas médias de crescimento da população total (\% a.a) entre as duas unidades de estudo.

A partir da Figura 39, observa-se que a taxa geométrica de crescimento anual da população para a Região Administrativa de Campinas vem decrescendo desde a década de 80. Entretanto, as taxas médias de crescimento da população total para as bacias dos rios Piracicaba e Corumbataí são superiores à taxa da Região Administrativa de Campinas.

A taxa média de crescimento dos municípios da bacia do rio Piracicaba também demonstra o mesmo comportamento decrescente, desde a década de 80 . No entanto, a bacia do rio Corumbataí teve taxa média de crescimento da população total superior àquela resultante para a bacia do rio Piracicaba, entre 91/00 e 00/02.

Pode-se inferir nessa análise de comportamento médio dos municípios nas duas bacias, que as taxas geométricas de crescimento da população total são preocupantes para as duas bacias em estudo, pois a degradação dos recursos hídricos, reflexo da ocupação antrópica das bacias, não tem demonstrado tendência de queda, nos principais corpos d'água monitorados.

No que se refere especificamente às perspectivas de manutenção da qualidade das águas do rio Corumbataí diante da evolução do crescimento demográfico apontado para os municípios da bacia, pode-se inferir que não há perspectivas otimistas. Justifica-se a afirmativa por alguns dos seguintes motivos principais: histórico 
de crescimento populacional da bacia do rio Piracicaba e seus efeitos sobre seus principais cursos d'água, lentidão com que estão sendo implantadas estações de tratamento de esgoto pelos municípios da bacia, ausência de ferramentas dos órgãos licenciadores que permitam o conhecimento da capacidade suporte do meio e imponham restrições de licenciamento à instalação de empreendimentos e lentidão na implantação da Agência de Bacias dos rios Piracicaba/Capivari/Jundiaí.

Foram reunidas de forma gráfica nas Figuras 40, 41 e 42, para a bacia do rio Piracicaba e nas Figuras 43, 44 e 45, para a bacia do rio Corumbataí, as taxas geométricas de crescimento da população total, por município, para os três períodos estudados.

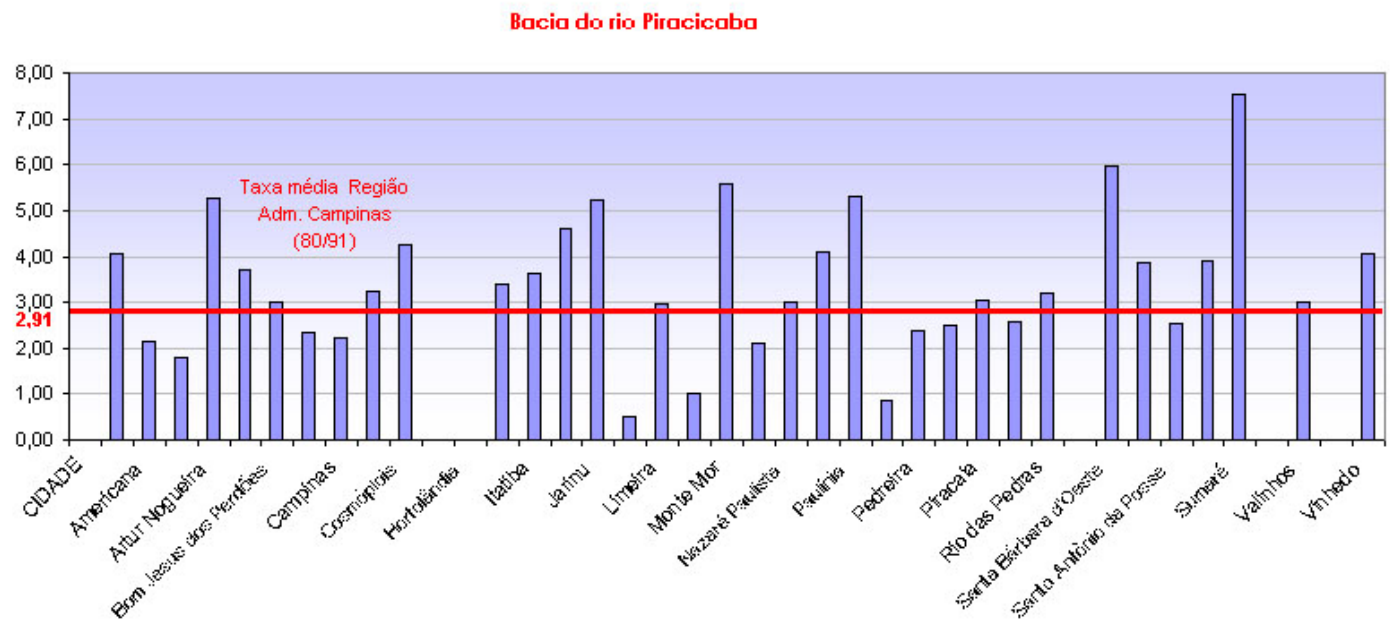

Figura 40 - Taxas geométricas de crescimento da população total por município (\% a.a) 1980-1991- bacia do rio Piracicaba. 


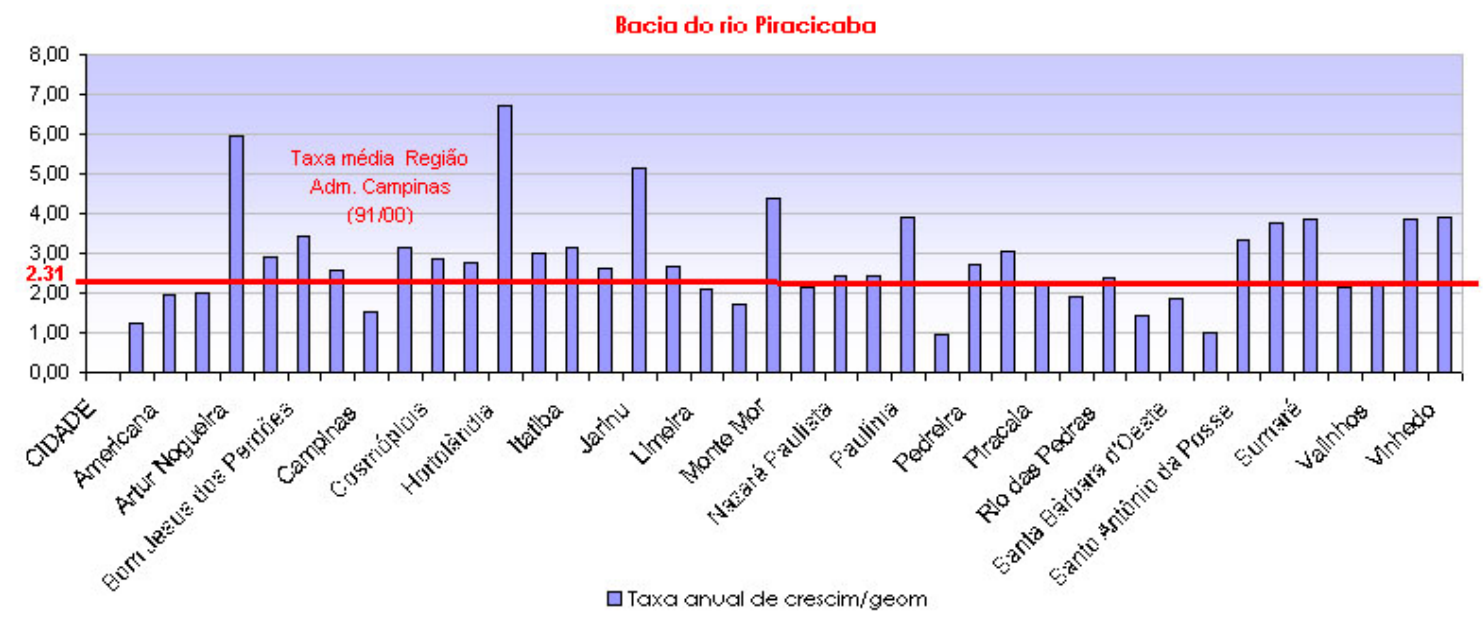

Figura 41 - Taxas geométricas de crescimento da população total por município (\% a.a) 1991-2000- bacia do rio Piracicaba.

Bacia do rio Piracicaba

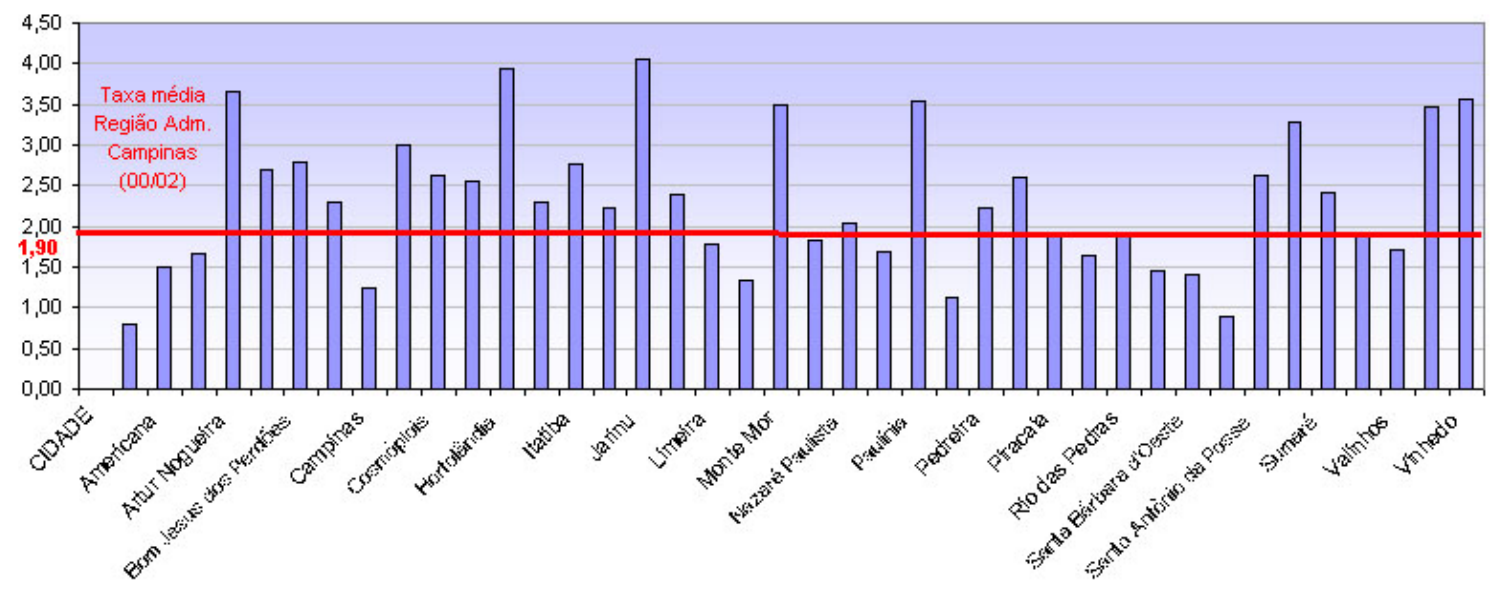

Figura 42 - Taxas geométricas de crescimento da população total por município (\% a.a) 2000-2002- bacia do rio Piracicaba. 
Bacia do rio Corumbataí

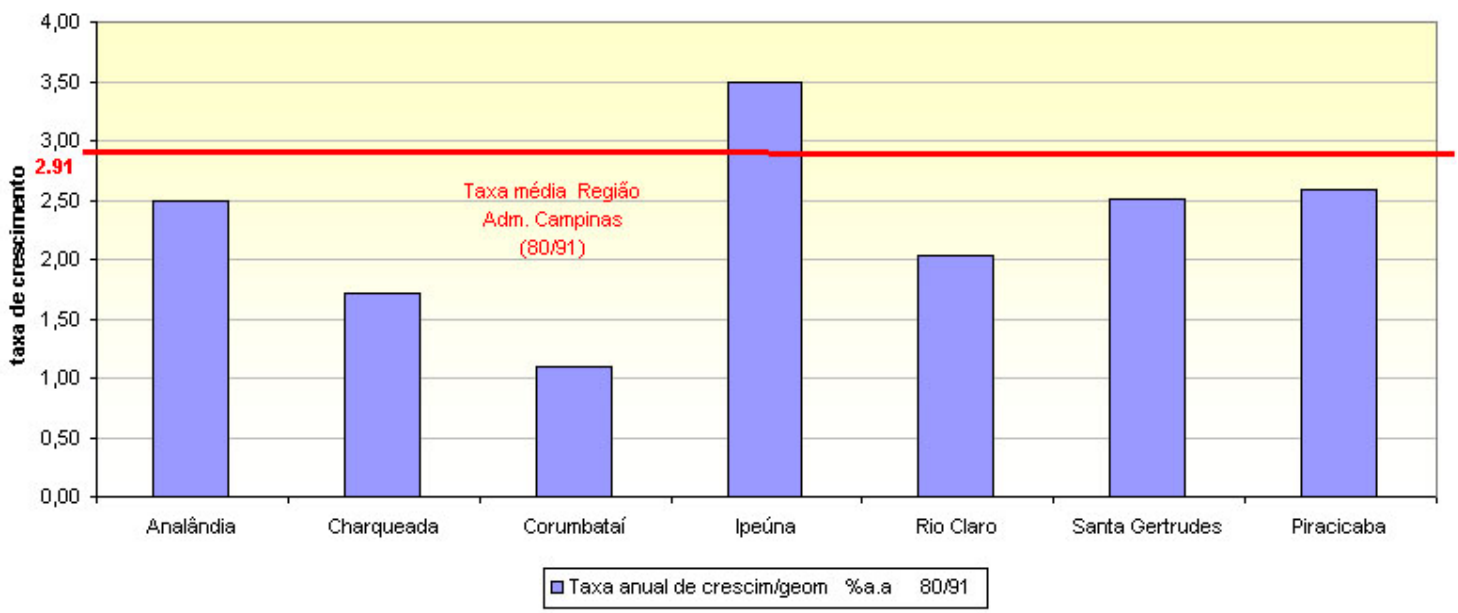

Figura 43- Taxas geométricas de crescimento da população total por município (\% a.a) 1980 -1991 - bacia do rio Corumbataí.

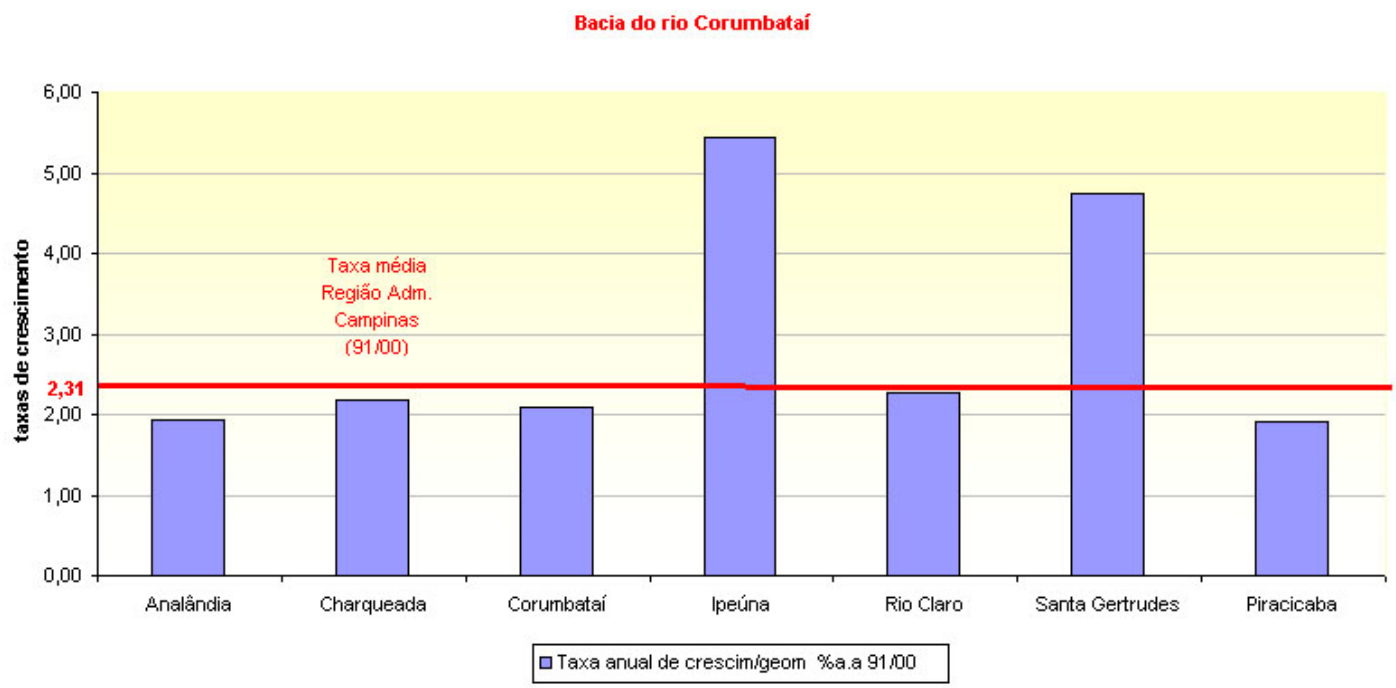

Figura 44- Taxas geométricas de crescimento da população total por município (\% a.a) 1991-2000- bacia do rio Corumbataí. 


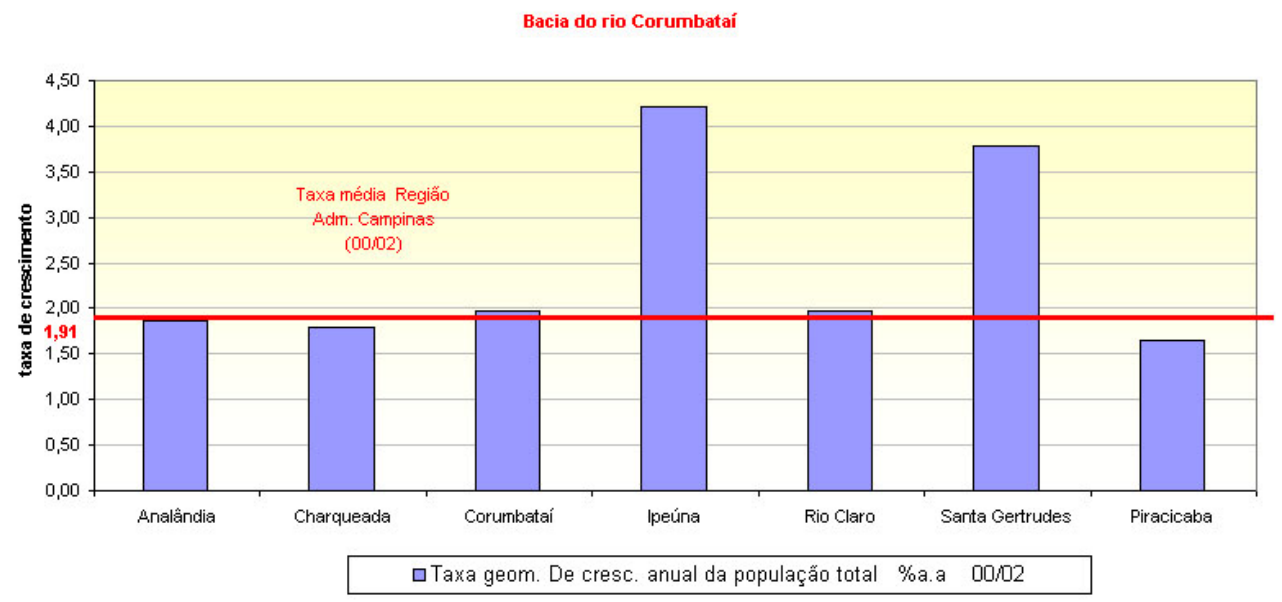

Figura 45 - Taxas geométricas de crescimento da população total por município (\% a.a) 2000-2002- bacia do rio Corumbataí O Quadro 34 mostra as taxas geométricas médias de crescimento da população total ao ano (\%a.a), para a Região Administrativa de Campinas, para o Estado de São Paulo, para as duas bacias hidrográficas em estudo e para outras regiões, já que elas são utilizadas, à título de comparação, na discussão do trabalho. O Quadro possui ainda a taxa de urbanização das regiões para o ano de 2000. 


\begin{tabular}{|c|c|c|c|c|}
\hline \multirow{2}{*}{ Região } & \multicolumn{3}{|c|}{ Taxa Geom. de cresc. da pop. Total ao ano (\% a.a.) } & $\begin{array}{c}\text { Taxa de } \\
\text { Urbanização \% }\end{array}$ \\
\cline { 2 - 5 } & $\mathbf{1 9 8 0}$ a 1991 & $\mathbf{1 9 9 1}$ a 2000 & $\mathbf{2 0 0 0}$ a 2002 & $\mathbf{2 0 0 0}$ \\
\hline Estado de São Paulo & 2,12 & 1,82 & 1,54 & 93,41 \\
\hline $\begin{array}{c}\text { Região Metropolitana } \\
\text { de São Paulo }\end{array}$ & - & 1,68 & 1,37 & 95,75 \\
\hline $\begin{array}{c}\text { Região Adm. de São } \\
\text { José dos Campos }\end{array}$ & - & 2,15 & 1,89 & 92,96 \\
\hline $\begin{array}{c}\text { Região Adm. de } \\
\text { Sorocaba }\end{array}$ & - & 2,31 & 2,04 & 83,54 \\
\hline $\begin{array}{c}\text { Região Adm. de } \\
\text { Campinas }\end{array}$ & 2,91 & 2,31 & 1,91 & 92,83 \\
\hline Bacia do rio Piracicaba & 3,40 & 2,84 & 2,31 & 93,33 \\
\hline $\begin{array}{c}\text { Bacia do rio } \\
\text { Corumbataí }\end{array}$ & 2,28 & 2,94 & 2,46 & 95,11 \\
\hline
\end{tabular}

Quadro 34.- Taxas geométricas de crescimento da população total ao ano para diferentes regiões Fonte: Adaptado de SEADE (2003)

A análise do Quadro 34 e das Figuras 37 a 45 revela que:

Para a bacia do rio Piracicaba: no período de $80 / 91,62,5 \%$ dos municípios possuíam taxas geométricas de crescimento da população total ao ano maiores do que a taxa da Região Administrativa de Campinas; no período de 91/00, esse percentual era de $62,5 \%$ e no período de 00/02, o percentual era de $61 \%$. Ou seja, aproximadamente $60 \%$ dos municípios, desde a década de 80 , crescem com taxas superiores àquela registrada para a Região Administrativa de Campinas.

Para a bacia do rio Corumbataí: no período de 80/91, 14,3 \% dos municípios possuíam taxas geométricas de crescimento da população total ao ano maiores do que a taxa da Região Administrativa de Campinas; no período de 91/00, esse percentual era de $28,6 \%$ e no período de 00/02, o percentual era de $57 \%$. Os municípios que registraram taxas mais elevadas para os períodos de 91/00 e 00/02 foram Ipeúna e Santa Gertrudes. Estes índices não indicam aumento proporcional de população, mas sim demonstram que, a cada período, um maior número de municípios vem crescendo de forma significativa na bacia. A manutenção do rio Corumbataí como principal manancial de abastecimento público de Piracicaba depende de políticas que garantam sustentabilidade aos recursos hídricos, já que inclusive ele está situado próximo de sua foz com o rio Piracicaba e o desenvolvimento acelerado dos municípios da bacia é indesejável. 
Para as bacias dos rios Corumbataí e Piracicaba: As taxas geométricas médias de crescimento da população total ao ano para o conjunto dos municípios das duas bacias, nos períodos mais recentes de 91/00 e 00/02, são superiores às obtidas para todas as regiões listadas no Quadro 34. As taxas de urbanização são superiores àquelas observadas para as Regiões Administrativas de Campinas e São José dos Campos. Depreende-se que os municípios estão concentrando sua população nas zonas urbanas e que a fixação da população rural no campo precisa de incentivos de alguma natureza. A fixação da população rural é importante para o desenvolvimento de ações de recuperação e conservação do solo e da cobertura florestal.

\subsubsection{Caracterização Econômica}

Os dados obtidos para o Valor Adicionado Fiscal Total para cada município; foram agrupados em valores médios, para as classes de municípios por população estabelecidas no estudo e confrontados em gráficos. A Figura 46 exprime estes resultados. 
MUNICíPIOS $<5000$ hab

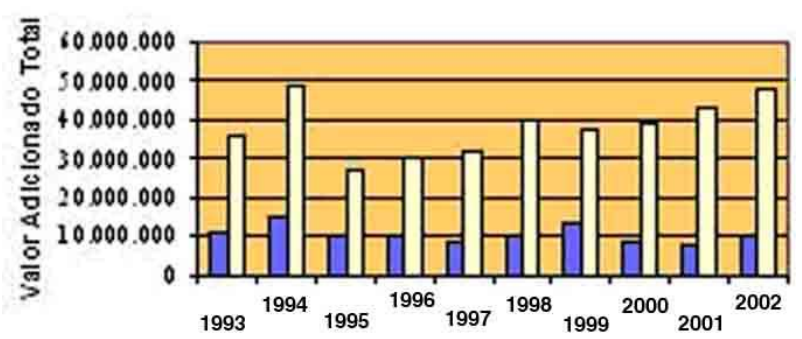

MUNICíPIOS entre 15 mil e 50 mil hab

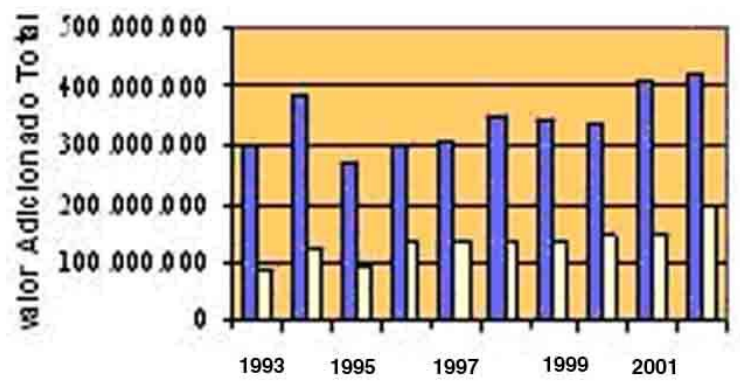

MUNICIP IOS entre 200 mil e 350 mil hab

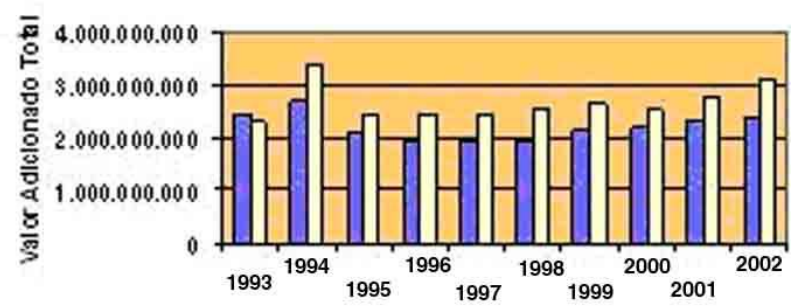

MUNICÍPIOS entre 5000 e 15000 hab

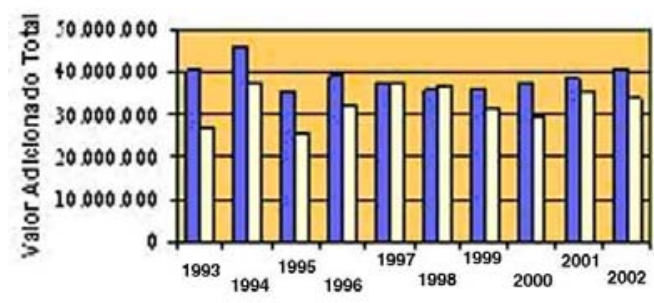

MUNIC ífIOS entre 100 mil e 200 mil hab

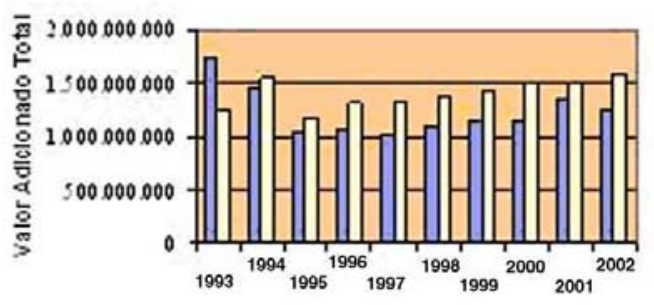

Bacia do rio Piracicaba

Bacia do rio Corumbataí

Figura 46 - Valor Adicionado Fiscal Total para as bacias dos rios Piracicaba e Corumbataí Fonte: SEADE (2003)

Os valores coletados são índices oficiais e portanto sujeitos à sonegação; no entanto são uma referência para retratar a economia nos municípios estudados. Dentro desta perspectiva, observa-se dos gráficos montados para as diversas classes populacionais dos municípios, que não se observa movimentação de queda do valor econômico agregado para os municípios das duas bacias hidrográficas, do rio Piracicaba e do rio Corumbataí. É preocupante a situação registrada para a bacia do rio Corumbataí, que para as três classes de municípios < 5000 hab, entre 100 e 200 mil 
hab. e entre 200 e 350mil hab., desde 1994 apresentam maior riqueza econômica gerada do que os municípios das mesmas classes da bacia do rio Piracicaba. Este registro é no mínimo preocupante e mostra uma realidade desenvolvimentista para a bacia do rio Corumbataí, nos diversos segmentos agrupados no Valor Adicionado Total, podendo-se destacar os valores industrial e agropecuário. Ambos estes valores são gerados a partir de atividades econômicas de grande impacto sobre as águas, considerando-se o uso e a qualidade. $O$ incremento da atividade econômica traz empregos e atrai a migração populacional.

\subsubsection{Instrumentos de Planejamento Municipal}

Os dados obtidos para municípios das duas bacias hidrográficas em estudo, para o ano de 1997 foram: 1) incentivos para a implantação de empreendimentos através da isenção de taxas; 2) incentivos para a implantação de empreendimentos através da doação de terrenos, 3) existência de Lei de Plano Diretor Municipal. Os resultados estão expressos nas Figuras 47 e 48. 


\begin{tabular}{|c|c|c|c|}
\hline \multicolumn{2}{|c|}{ BACIA DO RIO PIRA CICABA } & \multicolumn{2}{|c|}{ BACIA DO RIO CORUMBATAI } \\
\hline SM N/D & $\begin{array}{l}\square \mathrm{STM} \\
\square \mathrm{HAnO} 0 \\
\square \mathrm{FH} \\
\square \mathrm{H} / \mathrm{D} \\
\end{array}$ & $\begin{array}{l}\text { NÃ } \\
57 \%\end{array}$ & \begin{tabular}{|l|} 
SM \\
$\square$ NÃo \\
\end{tabular} \\
\hline
\end{tabular}

Figura 47 - Incentivos à implantação de empreendimentos através da isenção de taxas

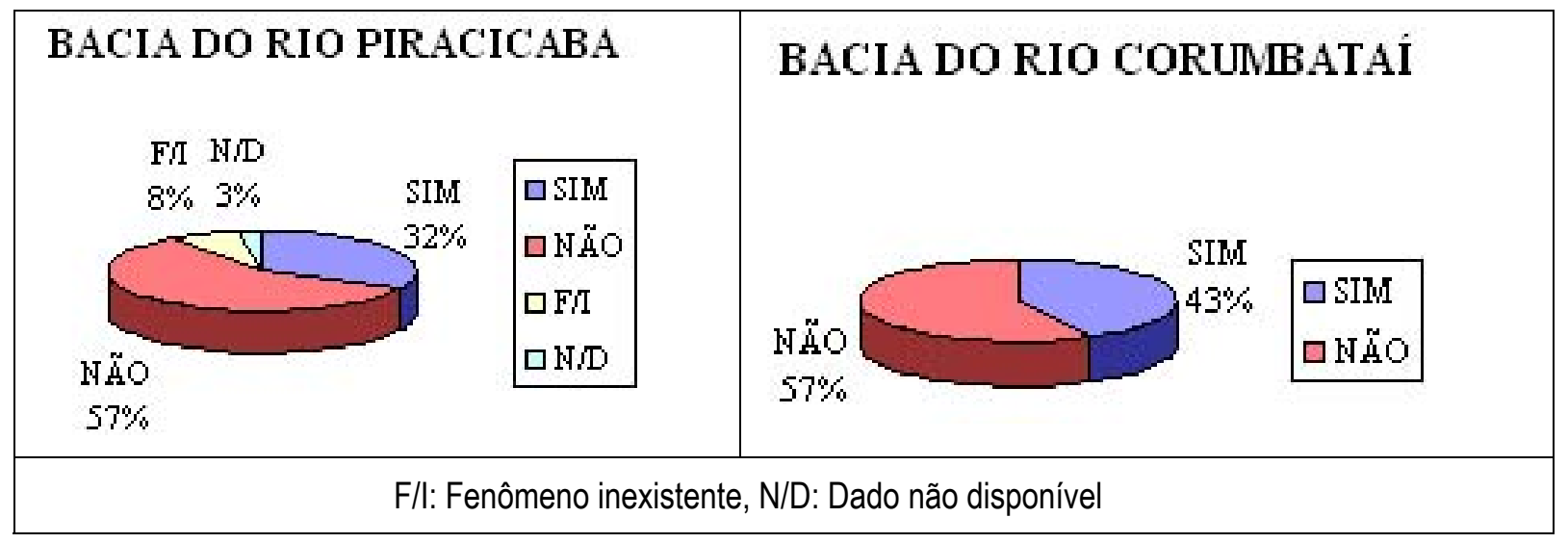

Figura 48 -- Incentivos à implantação de empreendimentos através da doação de terrenos

Como se observa na Figura 48, cerca de $35 \%$ dos municípios da bacia do rio Piracicaba oferecem incentivos de taxas para a instalação de empreendimentos e $32 \%$ oferecem esses incentivos através da doação de terrenos; para a bacia do rio Corumbataí, esse número cresce para $43 \%$, para as duas situações. Pode-se dizer que o comportamento médio dos municípios das duas bacias hidrográficas, para a instalação de empreendimentos, através de isenção de taxas e doação de terrenos, é semelhante, tomando-se como base as informações do ano de 1997. Os dados referentes ao município de Piracicaba estão computados para as duas bacias.

A existência ou não de Lei municipal de Plano Diretor para os municípios das bacias hidrográficas dos rios Piracicaba e Corumbataí estão expressos na Figura 
49.

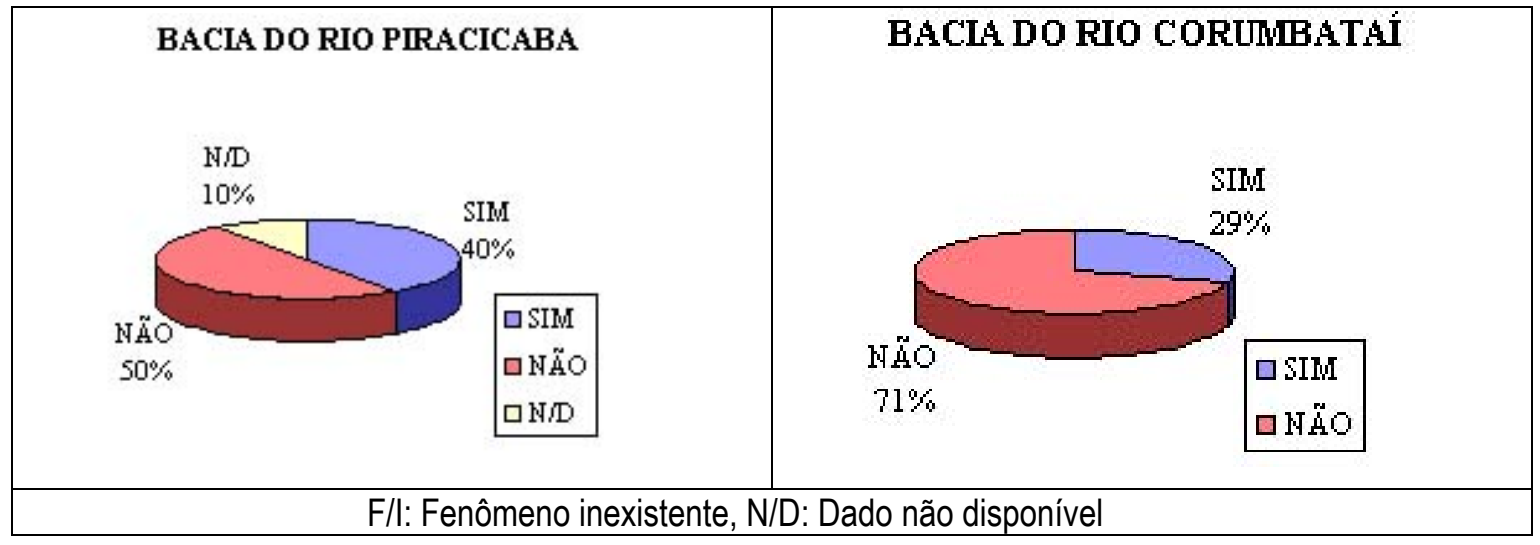

Figura 49 - Existência de Lei municipal instituindo o Plano Diretor

A análise dos dados referentes à Figura 49 mostra que em 1997, 71 \% dos municípios da bacia do rio Corumbataí não possuíam Plano Diretor. Na mesma data, 50 \% dos municípios da bacia do rio Piracicaba não possuíam Plano Diretor. A situação do planejamento do uso do solo não é confortável para nenhuma das bacias. Se por um lado, a bacia do rio Piracicaba possui um número muito maior de municípios e população também muito superior ao conjunto dos municípios da bacia do rio Corumbataí, por outro lado, o percentual dos municípios contemplados com a existência do Plano Diretor Municipal, na bacia do rio Corumbataí, é menor do que o que ocorre na bacia do rio Piracicaba.

A inexistência de Plano Diretor Municipal expressa a ausência de planejamento do município quanto ao uso de suas áreas. Isto reflete o provável desconhecimento das fragilidades e potencialidades de suas áreas, no que se refere à ocupação e conservação.

De acordo com Braga (1995), a atual obrigatoriedade da elaboração de planos diretores municipais, imposta pela Constituição Federal de 1988 (artigo 182), não foi novidade para os municípios paulistas. Já em 1967, a então Lei Orgânica dos Municípios (Lei 9482/67, posteriormente alterada pelo Decreto Lei Complementar 09 de 31/12/1969) determinava a obrigatoriedade da elaboração do plano diretor (então denominado Plano Diretor de Desenvolvimento Integrado, o chamado PDDI) a todos os municípios paulistas e, mais ainda, estabelecendo como punição aos municípios 
faltosos a proibição de auxílio financeiro pelo Estado.

Segundo Braga (1995), o plano diretor é um instrumento político e que deve ter por objetivo dar transparência e democratizar a política urbana. O autor critica o caráter eminentemente técnico dado à grande maioria dos planos diretores elaborados, os quais não incorporam a figura do político durante sua concepção. Disto decorre em muitos casos o surgimento de planos tecnicamente corretos, mas inviáveis politicamente

A bacia do rio Corumbataí guarda a responsabilidade de abastecer parcial ou totalmente todos os municípios nela inseridos. Assim, a ocupação inadequada dos contribuintes do rio Corumbataí e da área de drenagem de sua calha principal é indesejável.

A análise dos dados para a bacia do rio Corumbataí, para o ano de 1997, demonstrou então que o planejamento municipal do uso do solo não é uma ferramenta legal consolidada nos municípios da bacia. Isso já está trazendo efeitos sobre os corpos d'água contribuintes diretos ou indiretos do rio Corumbataí.

Pode-se mencionar aqui o grave problema de abastecimento público enfrentado atualmente pelo município de Santa Gertrudes. O município possui como manancial de abastecimento público o córrego Santa Gertrudes, afluente do ribeirão Claro, que por sua vez é afluente do rio Corumbataí. Nas cabeceiras do córrego Santa Gertrudes existem diversas áreas de lavra de argila, com autorização fornecida em primeira instância pelo poder municipal. Cerca de dois anos após o início das atividades de lavra de mais de 80 \% dessas empresas, o município teve sua captação paralisada por pelo menos duas vezes, pelo excesso de turbidez e sólidos nas águas do córrego Santa Gertrudes. O município atentou-se para o risco e buscou sustentação jurídica a fim de estabelecer restrições, para a ampliação de tais empreendimentos minerários. Conforme informação do município, a ausência de um Plano Diretor inviabilizou a negativa do pedido de ampliação dos empreendimentos. O setor cerâmico é responsável por boa parte da geração de renda do município, o que favorece a ocorrência de pressões indevidas sobre o poder público local. Neste caso, a pressão do poder econômico sobre a gestão municipal ganha mais força, quando não existe legislação que disciplina o uso e ocupação da terra.

Em julho de 2001 foi promulgada a Lei federal $n^{\circ}$ 10.257, que regulamenta os artigos 182 e 183 da Constituição Federal, que estabelece diretrizes 
gerais da política urbana e dá outras providências Ela foi denominada Estatuto da Cidade. Esta lei, no Capítulo de Diretrizes Gerais, dentre outras diretrizes, estabelece que: o planejamento do desenvolvimento das cidades, da distribuição espacial da população e das atividades econômicas do Município e do território sob sua área de influência, deve ser feito de modo a evitar e corrigir as distorções do crescimento urbano e seus efeitos negativos sobre o meio ambiente". O Estatuto da Cidade prevê o planejamento de uso e ocupação do solo de todo o território municipal, não somente da zona urbanizada, o que é muito importante para impor maior domínio do município sobre seu território, entretanto, sua obrigatoriedade recai apenas sobre municípios com mais de 20.000 habitantes. A Lei oferece outros recursos de disciplinamento do planejamento municipal, para os municípios em geral, tais como: disciplina do parcelamento, do uso e da ocupação do solo, zoneamento ambiental.

O uso do Estatuto da Cidade como mecanismo disciplinador do crescimento urbano e da ocupação do território municipal, com a participação dos segmentos da sociedade envolvidos, é uma das legislações que deve contribuir, a médio prazo, com o estabelecimento de políticas urbanas que favoreçam à conservação de mananciais de abastecimento público e garantam a perpetuação do rio Corumbataí como manancial de abastecimento público.

\subsubsection{Qualidade de vida}

O cálculo dos valores médios dos índices IDH-M e IPRS para cada bacia inclui o município de Piracicaba nas duas unidades de estudo.

A Figura 50 demonstra a evolução dos IDH-M médios, por bacia, para as classes de municípios eleitas neste trabalho, para dar caráter menos genérico às conclusões. 


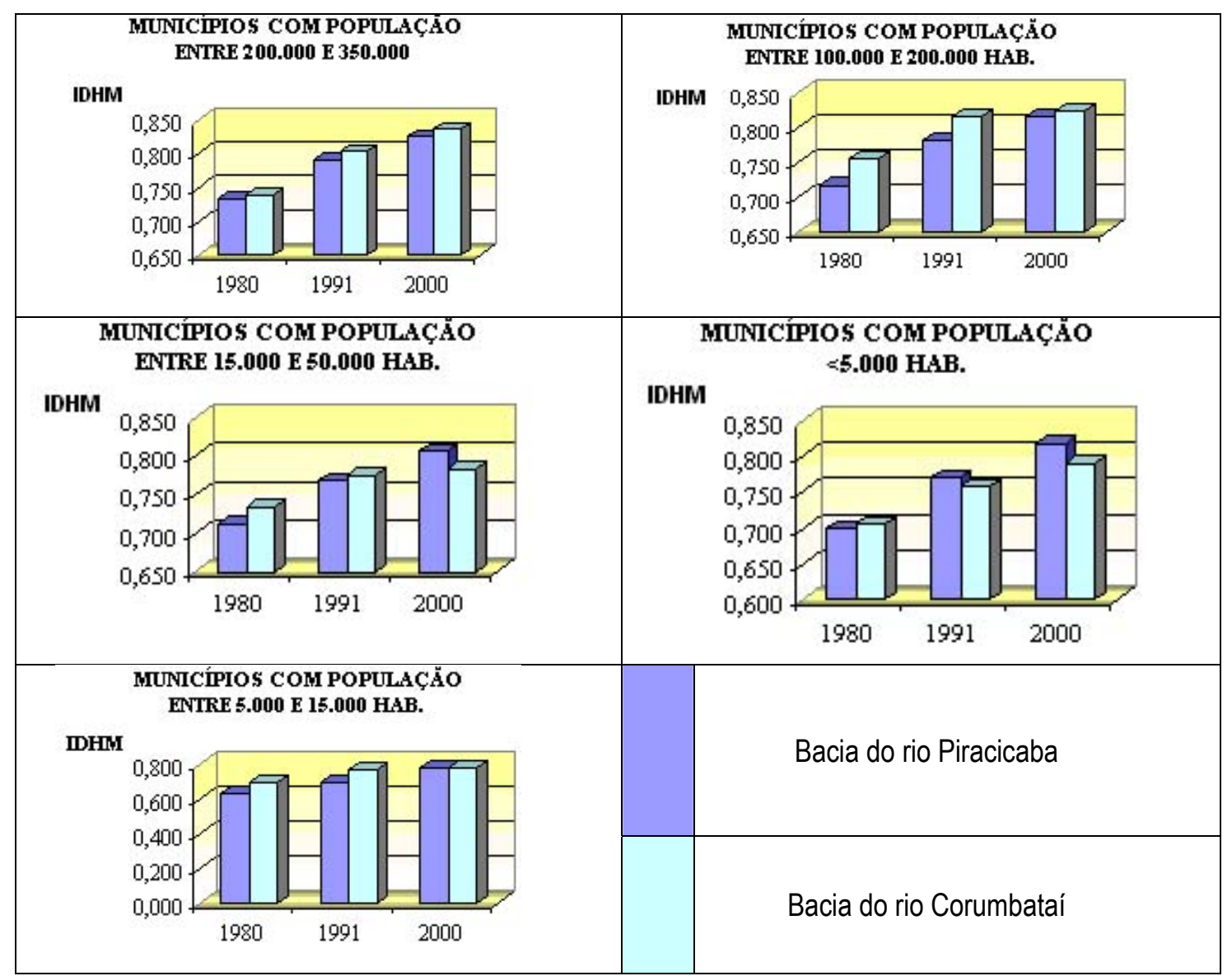

Figura 50 - IDH-M médio dos municípios de cada bacia hidrográfica para os anos de 1980/1991/2000 Fonte: SEADE (2003)

O comportamento médio do IDH-M para o conjunto dos municípios das duas bacias hidrográficas demonstra crescimento do índice ao longo dos anos, independentemente da classe que define o número de habitantes. Este resultado expressa a inadequação do índice para se inferir a partir da qualidade de vida, a qualidade do meio. Sabe-se que a composição do índice envolve educação, renda e longevidade. Este é um índice reconhecido pelas autoridades e pela população como parâmetro cujo progresso no ranking de classificação é sempre desejado pelos municípios e perseguido pela população que almeja melhores condições de vida. Entretanto, este índice não tem qualquer vínculo com a qualidade do meio e no entanto cresceu significativamente na maior parte dos municípios das bacias dos rios Piracicaba e Corumbataí, enquanto, sabe-se, a qualidade das águas dos corpos d'água principais 
para abastecimento público vêm decrescendo no mesmo período de tempo, quando não permeando dentro de faixa de qualidade regular. Em 2000, o município de Águas de São Pedro foi classificado na segunda posição do ranking dos municípios paulistas, entretanto não trata 1 litro de seu esgoto urbano. Recentemente foram aprovados loteamentos que lançarão esgoto tratado a montante do seu principal manancial de captação, sem que isso fosse considerado um fato relevante para a companhia de águas responsável pelo gerenciamento municipal.

A qualidade das águas para abastecimento público está intimamente ligada aos riscos envolvidos na saúde da população. Em 2000, o IDH-M médio para a bacia do rio Piracicaba foi de $\mathbf{0 , 8 1 9}$ e para a bacia do rio Corumbataí $\mathbf{0 , 8 0 3}$. Sabe-se que países com IDH maior que 0,800 têm desenvolvimento humano considerado alto. Se o IDH-M vem sendo utilizado como ferramenta de planejamento para estabelecimento de políticas públicas, e o viés ambiental está sendo desconsiderado, isto pode eventualmente implicar em erros de avaliação regional, se considerada a capacidade suporte do meio. 
A Figura 51 exibe a evolução do agrupamento de municípios em torno das classes G1, G2, G3, G4 e G5, conforme definição do IPRS paulista.

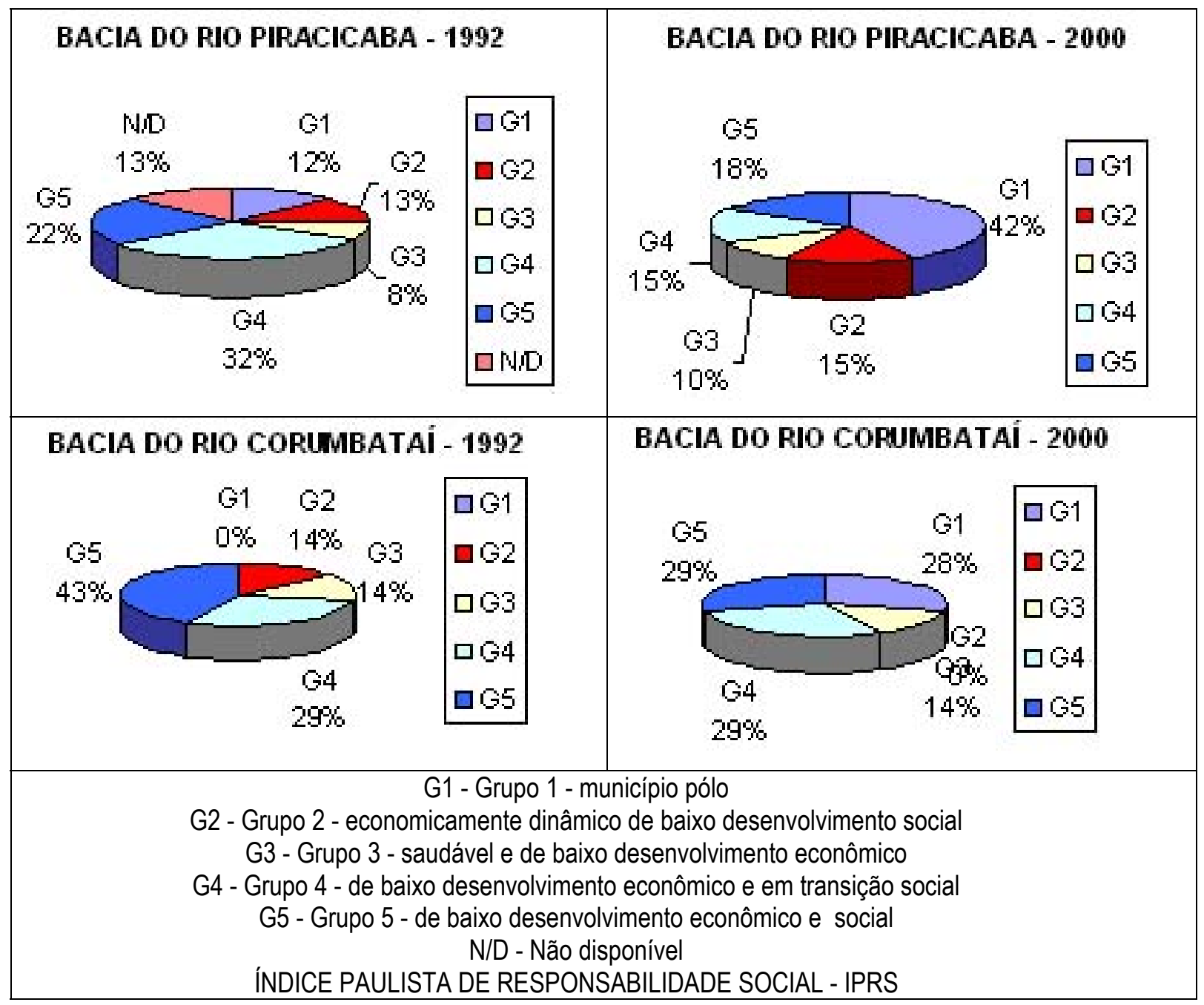

Figura 51 - IPRS para cada bacia hidrográfica para os anos de 1992 e 2000

O ÍNDICE PAULISTA DE RESPONSABILIDADE SOCIAL - IPRS apresenta, da mesma forma que o IDH-M, resultado que reflete o crescimento dos níveis de riqueza, escolaridade e longevidade dos municípios paulistas estudados em 1992 e 2000. Este índice, conforme seu histórico é fruto de discussões do Fórum São Paulo Século XXI e foi instituído por lei no Estado de São Paulo, com a finalidade de ser utilizado para o planejamento de políticas públicas dos municípios e para dar visibilidade da gestão pública à sociedade civil. Assim como nas décadas de 70 e 80 a 
industrialização do interior paulista foi incentivada pelo Estado, o incentivo ao desenvolvimento de municípios com base apenas neste tipo de índice pode ser desastroso. A elevação do número de municípios que integram o Grupo G1 em 2000 nas duas bacias hidrográficas retrata uma realidade que teve um custo ambiental não bem dimensionado e sequer estimado, mas que a transferência da captação do município de Piracicaba, do rio Piracicaba para o rio Corumbataí é um símbolo deste custo incorporado pela sociedade.

Faz-se necessária neste tipo de índice, a inclusão de uma variável ambiental que reflita minimamente a capacidade suporte do meio para se contrapor ao desenvolvimento inquestionável de algumas regiões do Estado de São Paulo. A recente pressão das esferas governamentais pela instalação de uma usina termelétrica na bacia do rio Piracicaba mostrou falta de conhecimento das limitações da disponibilidade hídrica do rio Piracicaba e da saturação da qualidade do ar na região.

A saturação da qualidade de um rio, bem como da sua disponibilidade hídrica, pode comprometer toda uma política desenvolvimentista dirigida pelo Estado a uma determinada região. A capacidade de migração de fontes de abastecimento público e privado é cada vez mais limitada e os custos de transposição de bacias altíssimos. Por outro lado a sociedade cada vez mais se mobiliza pela manutenção dos seus recursos hídricos diante da vivência de experiências desinteressantes, como é o caso da transposição de 31 m³/s do Sistema Cantareira para abastecer a Grande São Paulo.

\subsubsection{Qualidade das águas}

A análise da evolução da qualidade das águas dos rios Piracicaba e Corumbataí foi realizada através da observação do comportamento dos parâmetros de qualidade descritos no Capítulo Materiais , no universo de 1978 a 2003, nos períodos de estiagem e chuvas, nos seguintes pontos de monitoramento:

- Rio Piracicaba: PCAB02192 - Ponte na estrada Piracicaba/ Limeira, próximo à Usina Monte Alegre

- Rio Piracicaba: PCAB02220 - Captação do município de Piracicaba

- Rio Corumbataí: CRUM02500 - Captação do município de Piracicaba

No ponto PCAB02192, o rio Piracicaba já recebeu as contribuições de todos os municípios situados a montante do município de Piracicaba, incluindo-se aí a carga poluidora de toda a Região Metropolitana de Campinas. Este ponto de 
monitoramento está situado a montante dos maiores lançamentos de esgotos do município de Piracicaba e a montante da sua captação para abastecimento público, no rio Piracicaba.

O ponto PCAB02220 situa-se um pouco abaixo do PCAB02192 e está na captação do município de Piracicaba. O ponto possui monitoramento de THMs, algas e protozoários como Giardia e Cryptosporidium e universo de tempo monitoramento de 1989 a 2003. Alguns parâmetros passaram a ser monitorados apenas a partir do final da década de 90 .

O ponto CRUM02500 situa-se no Baixo Corumbataí, a montante de uma grande Usina de açúcar e álcool da região e a montante das contribuições do município de Piracicaba. Neste ponto, o rio já recebeu grande parte das contribuições urbanas, industriais e difusas e normalmente já apresenta recuperação de sua qualidade, particularmente após o impacto do lançamento de esgotos urbanos e industriais dos municípios de Rio Claro e Santa Gertrudes.

\section{IAP e IQA}

A Figura 52 indica os pontos de monitoramento estudados e outros da rede de monitoramento da CETESB para o ano de 2003. As cores dos rios indicam a qualidade do IAP para cada trecho.

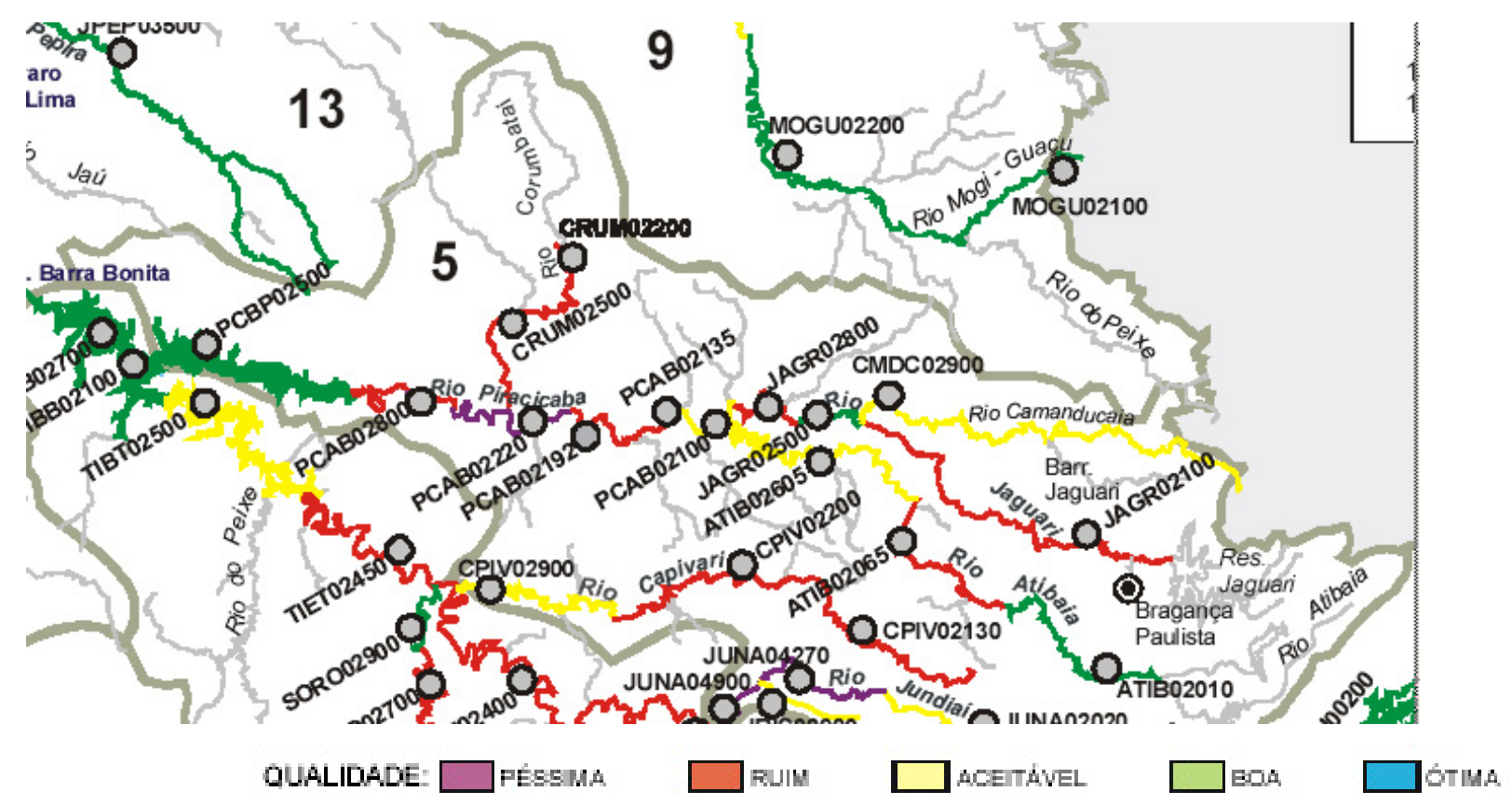

Figura 52- IAP 2003 para as águas da UGRHI 05 nos pontos de monitoramento da rede de monitoramento da CETESB Fonte: CETESB (2004) 
Como se pode apreender da Figura 52, o IAP médio para o ponto de captação do município de Piracicaba (PCAB02220), no rio Piracicaba, em 2003 foi considerado péssimo e o IAP médio para o ponto de captação do município de Piracicaba (CRUM02500), o rio Corumbataí em sua captação foi novamente considerado ruim. O IAP 2003 para estes dois pontos repetiu os valores registrados para o ano de 2002, quando o índice foi oficialmente implantado pela CETESB.

A qualidade das águas do rio Piracicaba é considerada péssima para o abastecimento público, quadro que reflete a condição de ocupação da bacia, o baixo índice de tratamento de esgotos urbanos, a ausência de procedimentos que visem minimizar a entrada de carga difusa de poluição advindas das áreas rural e urbana e, diante do alto comprometimento da qualidade das águas da bacia, a impossibilidade de aprimoramento das exigências para a minimização de lançamento de cargas industriais. Desde Dezembro de 2002, o Estado de São Paulo conta com importante ferramenta de controle sobre os empreendimentos licenciáveis dentro do sistema ambiental, trata-se do licenciamento renovável. Este instrumento permitirá à CETESB estabelecer metas ambientais a serem cumpridas pelos empreendimentos. Diante do quadro atual de comprometimento da qualidade dos rios da bacia do rio Piracicaba, poucos avanços conseguem ser ambientalmente medidos mediante o pré-estabelecimento de variáveis ambientais. A elevação do índice de tratamento de esgotos urbanos e a brevidade com que estas obras devem ser realizadas são fatores fundamentais para que se vislumbre a possibilidade de recuperação dos principais rios da bacia do Piracicaba.

O rio Corumbataí possui IAP ruim e o retrato que envolve a situação da qualidade das águas é muito semelhante ao relatado para a bacia do rio Piracicaba. O rio Corumbataí não possui áreas urbanizadas tão extensas, mas possui 43,68 \% de áreas cobertas por pastagens e 25,57 \% de áreas cobertas por cana-de-açúcar, mostrando a importância do meio rural sobre a qualidade das águas da bacia. As análises sobre o crescimento populacional e sobre o Valor Adicionado Total da bacia do rio Corumbataí indicam que não há indicação de queda para estes índices. A persistirem as situações relatadas, não há perspectiva para a melhora do IAP a curto prazo.

A adoção do IAP pela CETESB como índice de referência para abastecimento público, o que antes era atribuído ao IQA, foi um avanço ambiental e 
adequou a qualificação da medição à realidade da qualidade das águas. O IQA mascara a real condição da qualidade das águas para abastecimento público, sendo útil como um índice mais genérico.

As Figuras 53 e 54 mostram o comportamento do IQA para os pontos de monitoramento nos rios Piracicaba e Corumbataí entre 1984 e 2000. Ressalta-se que a classificação para o IQA remete-se às qualidades Ótima, Boa, Regular, Ruim e Péssima para o abastecimento público.

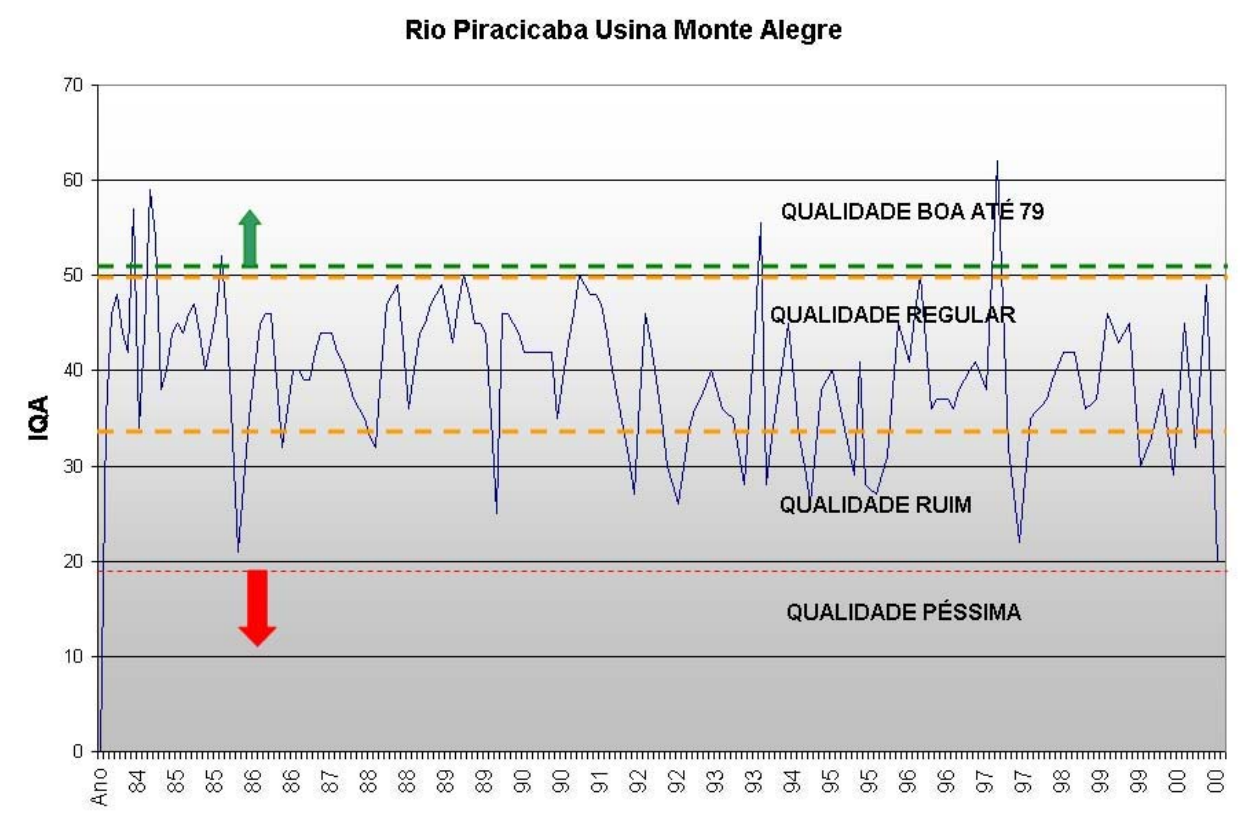

Figura 53- IQA no rio Piracicaba de 1984 a 2000 no PCAB02192

Fonte: CETESB (2003) 


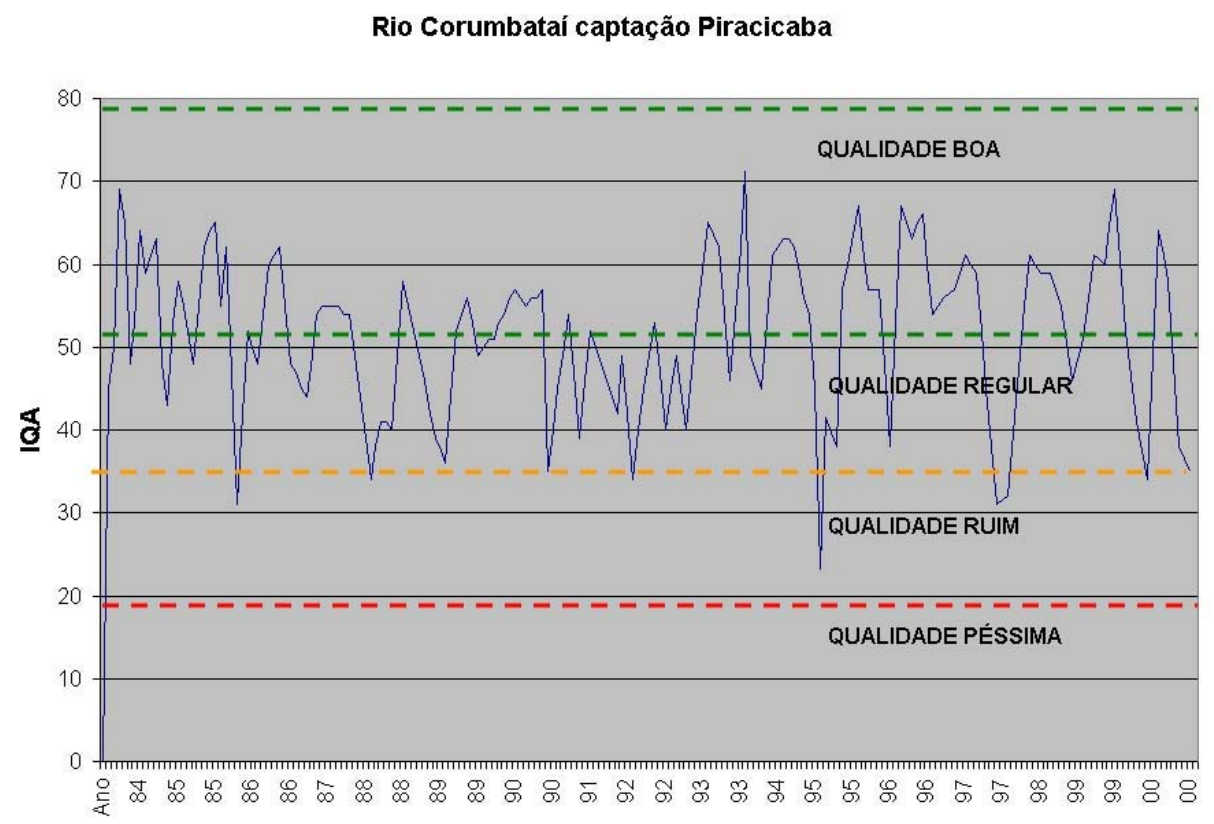

Figura 54 - IQA no rio Corumbataí de 1984 a 2000 no CRUM02500 Fonte: CETESB (2003)

Não se observa diferença expressiva na análise dos dois gráficos do IQA para os rios Piracicaba e Corumbataí. Ambos possuem boa parte de sua história situada na faixa regular. O rio Corumbataí, de 1992 a 2000 apresenta uma melhora na qualidade de seu IQA, talvez pela implantação de tratamento parcial dos esgotos urbanos, mas cujo percentual não se pode considerar expressivo.

As Figuras 55 e 56 expõem a evolução do comportamento do Oxigênio dissolvido nas águas dos rios Piracicaba e Corumbataí respectivamente, ao longo dos anos de 1978 a 2003, nos pontos de monitoramento descritos. 


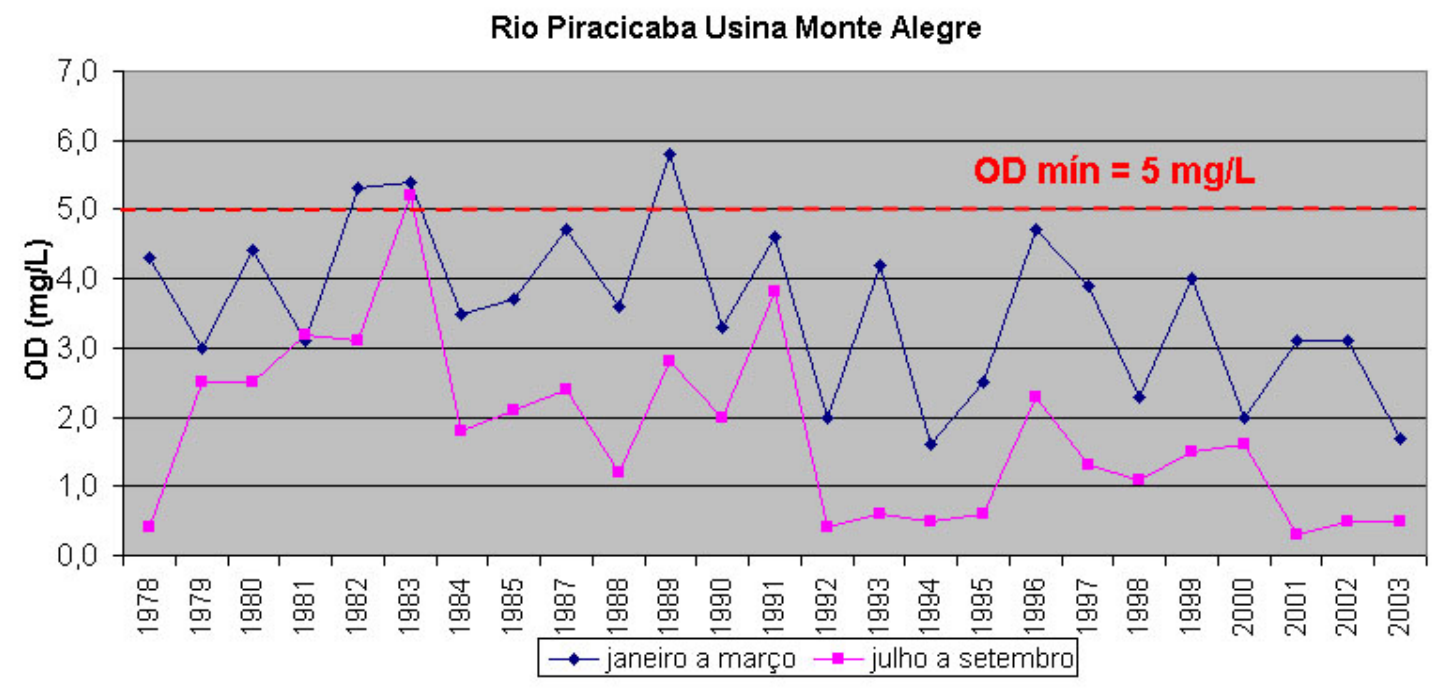

Figura 55- Oxigênio Dissolvido no rio Piracicaba de 1978 a 2003 no PCAB02192

Fonte: CETESB (2003)

\section{Rio Corumbataí captação Piracicaba}

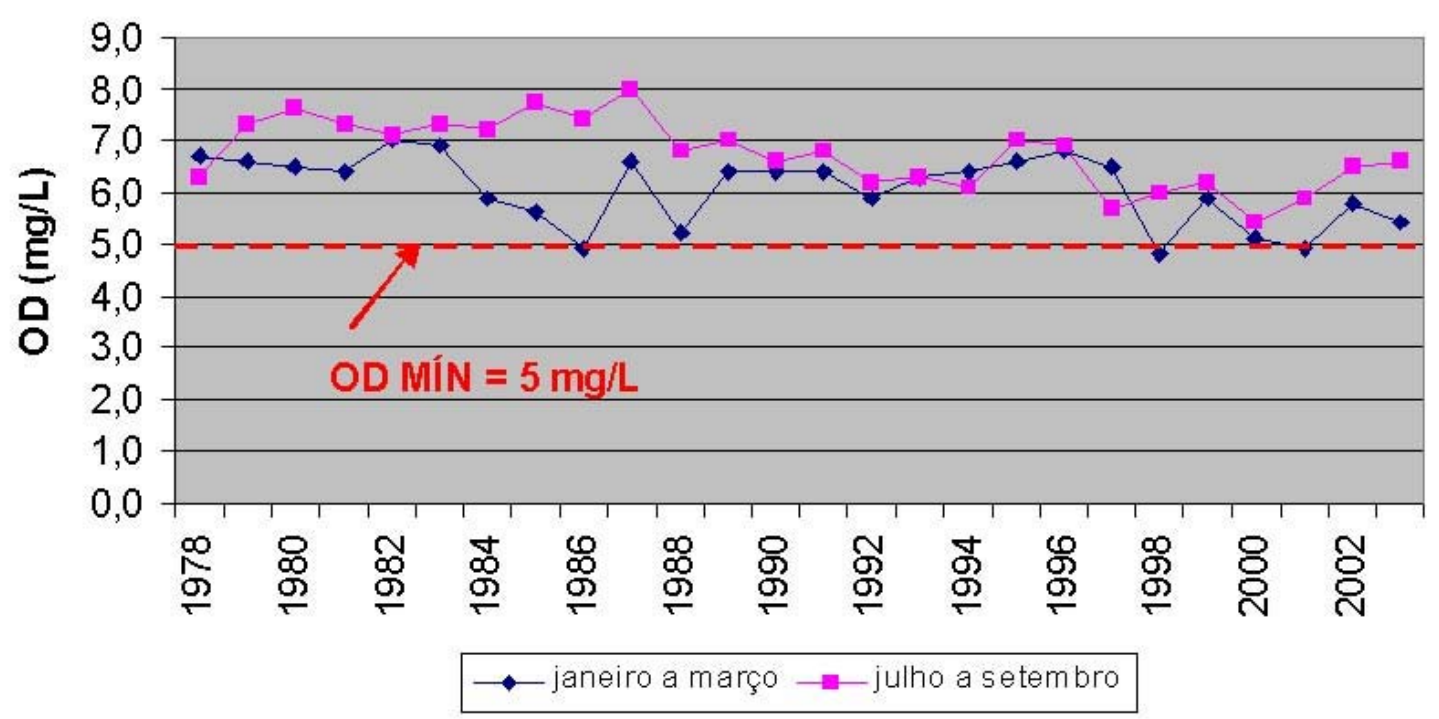

Figura 56 - Oxigênio Dissolvido no rio Corumbataí de 1978 a 2003 no CRUM2500

Fonte: CETESB (2003)

O comportamento histórico do parâmetro Oxigênio Dissolvido no rio 
Piracicaba, desde 1978 mostra tendência aparente de queda, principalmente na estiagem e entre os intervalos de 1992 a 1995 e 2001 a 2003. Na estiagem, as vazões advindas do Sistema Cantareira para a bacia do rio Piracicaba, particularmente nos últimos 4 anos têm sido muito baixas, refletindo na qualidade das águas dos rios. Sabese que os períodos de estiagem têm sido severos, entretanto o fato é que a população que se abastece das águas dos rios da bacia do rio Piracicaba tem sido prejudicada.

No início do monitoramento da CETESB, em 1978, a realidade da qualidade das águas do rio Piracicaba já era insatisfatória e algumas melhoras podem ter sido registradas, fruto da ausência de controle do Estado, também sobre os efluentes industriais que existiam àquela época e muitos eram lançados aos corpos d'água sem prévio tratamento. Desde 1989 não há registro de OD dentro da legislação neste ponto de monitoramento do rio Piracicaba. Este ponto recebe toda a contribuição da bacia do rio Piracicaba, com o atenuante considerado da redução de parte da carga orgânica, pela existência da represa de Salto Grande no município de Americana, que termina por funcionar como uma grande lagoa de estabilização.

O rio Corumbataí por sua vez mostra-se menos comprometido no parâmetro OD, com praticamente nenhum registro inferior ao valor legal de 5,0 mg/L durante todo o período de registros de monitoramento. A condição do rio nas duas estações de estiagem e cheia também anão apresentam quadro com diferenças expressivas, mostrando maior estabilidade do rio. O rio Corumbataí está sujeito a uma carga muito menor de contribuição orgânica do que o rio Piracicaba e este ponto de monitoramento reflete a condição do rio em um ponto onde ele já se recuperou da maior carga lançada pelo município de Rio Claro.

As Figuras 57 e 58 exibem a evolução do comportamento da $\mathrm{DBO}_{5,20}$ nas águas do rio Piracicaba e do rio Corumbataí respectivamente, ao longo dos anos de 1978 a 2003, nos pontos de monitoramento descritos. 


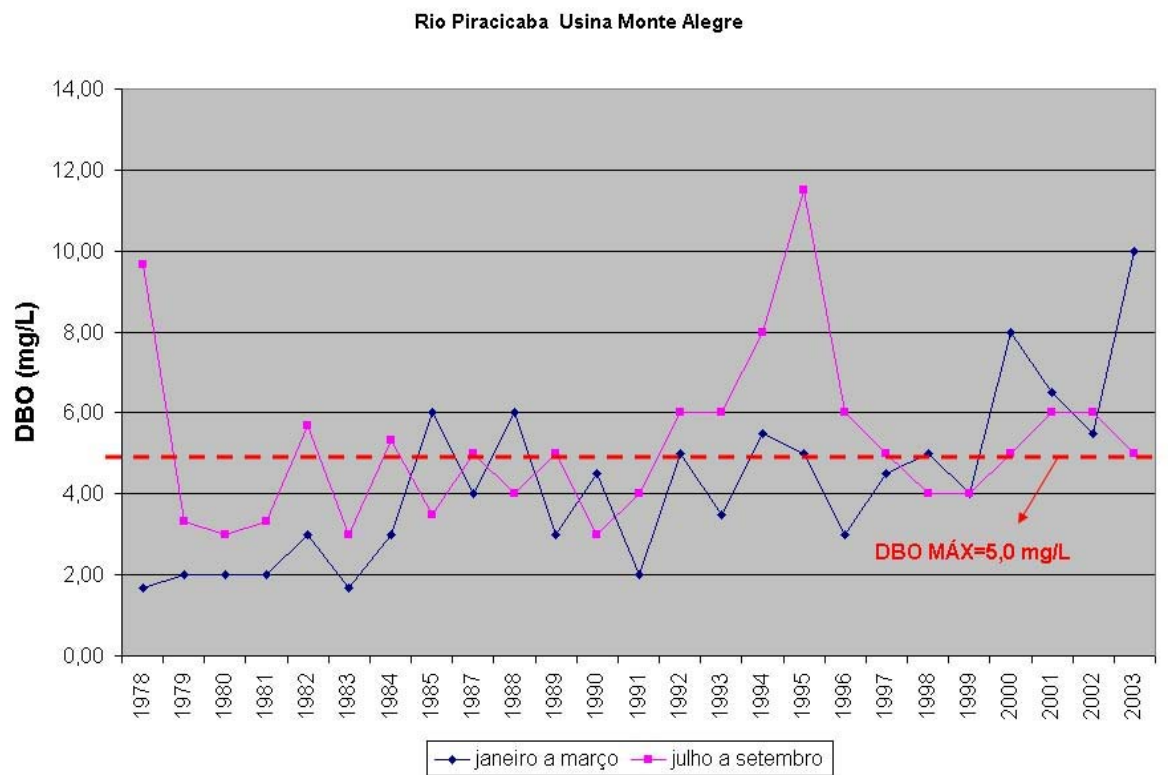

Figura 57- Demanda Bioquímica de Oxigênio no rio Piracicaba de 1978 a 2003 no PCAB02192 Fonte: CETESB (2003)

Rio Corumbataí captação de Piracicaba

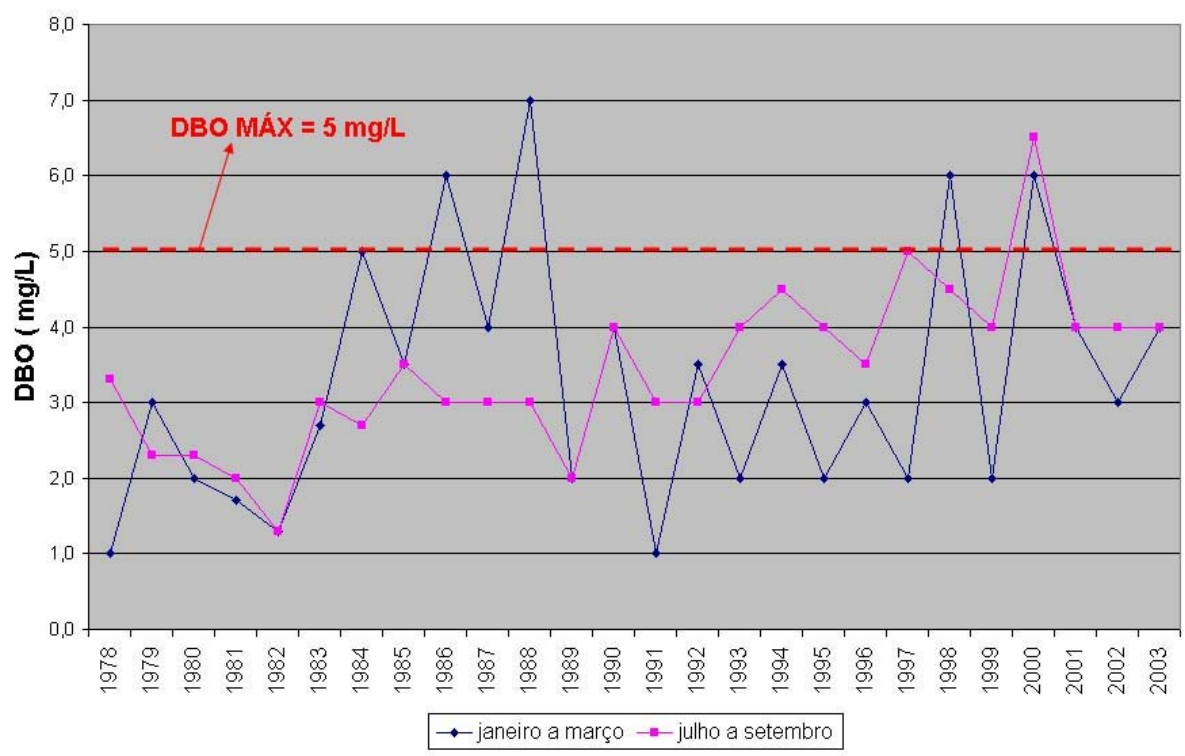

Figura 58- Demanda Bioquímica de Oxigênio no rio Corumbataí de 1978 a 2003 no CRUM2500 Fonte: CETESB (2003)

$\mathrm{Na}$ análise dos gráficos que expressam o comportamento da DBO 5,20 observa-se sua elevação nos últimos cinco anos, para os períodos de estiagem e 
chuvoso no rio Piracicaba.

No rio Corumbataí, observa-se comportamento preocupante desse parâmetro, constatando-se que desde 1992 registra-se aparente tendência de crescimento, particularmente na estiagem. A expectativa pelo aumento do percentual de tratamento de esgotos na bacia do rio Corumbataí pode reverter esta tendência de elevação da DBO no rio.

A concentração de carga orgânica e consequentemente de nutrientes como o fósforo, a boa insolação e baixas vazões do período de estiagem, já levaram o SEMAE a paralisar sua captação, no ano de 2001, em decorrência de episódio de crescimento de algas. Não voltaram a ocorrer episódios nos anos seguintes, mas tratase de um forte indicativo de que a capacidade suporte do rio está ficando comprometida pela entrada de alta carga de nutrientes, lançados por esgotos urbanos, industriais e pelo desenvolvimento da atividade agrícola, principalmente pelo cultivo da cana-deaçúcar, que representa cerca de $26 \%$ do uso do solo na bacia. Lembra-se que durante o período da estiagem ocorre a safra da cana na região e todos os cortes, a colheita e a aplicação de vinhaça e outros nutrientes no solo. Em decorrência dos episódios de eutrofização que ocorreram no rio Corumbataí, o SEMAE viu-se obrigado a criar estrutura para monitorar regularmente a diversidade das algas na altura da captação para abastecimento público, preocupado com a proliferação de algas tóxicas que possam vir a comprometer a qualidade das águas servidas à população. Os episódios de proliferação de algas não são incomuns na bacia do rio Piracicaba. Na UGRHI 05, nos anos de 2001 e 2002 foram registradas 15 ocorrências de proliferação de cianobactérias em captações de abastecimento público, com 4 episódios apenas no rio Atibaia. e 7 no rio Piracicaba entre as captações de Piracicaba e Americana. As cianobactériasa ou algas azuis podem liberar metabólitos secundários tóxicos conhecidos como cianotoxinas para o meio, cujo efeito sobre a saúde humana pode ser neurotóxico ou hepatóxico. As ETAS convencionais em geral não estão preparadas para eliminar esta toxicidade da água, podendo colocar a saúde da população em risco (Agujaro \& Isaac, 2003).

As estações de tratamento de esgoto que vem sendo projetadas e implantadas nas bacias dos rios Piracicaba e Corumbataí não possuem tecnologia para remoção de nutrientes, o que também em geral não ocorre nas ETEs industriais. Assim, as perspectivas não são otimistas para o rio Corumbataí, que neste estudo é destacado, 
diante do que vem ocorrendo no rio Piracicaba em termos de floração de cianobactérias e da ausência de preocupação dos gestores com relação à entrada de nutrientes em mananciais de abastecimento público.

As Figuras 59 e 60 retratam a evolução do comportamento do potencial da formação de trialometanos nas águas dos rios Piracicaba e Corumbataí, ao longo dos anos de 1999 a 2003, nos pontos de monitoramento descritos. 


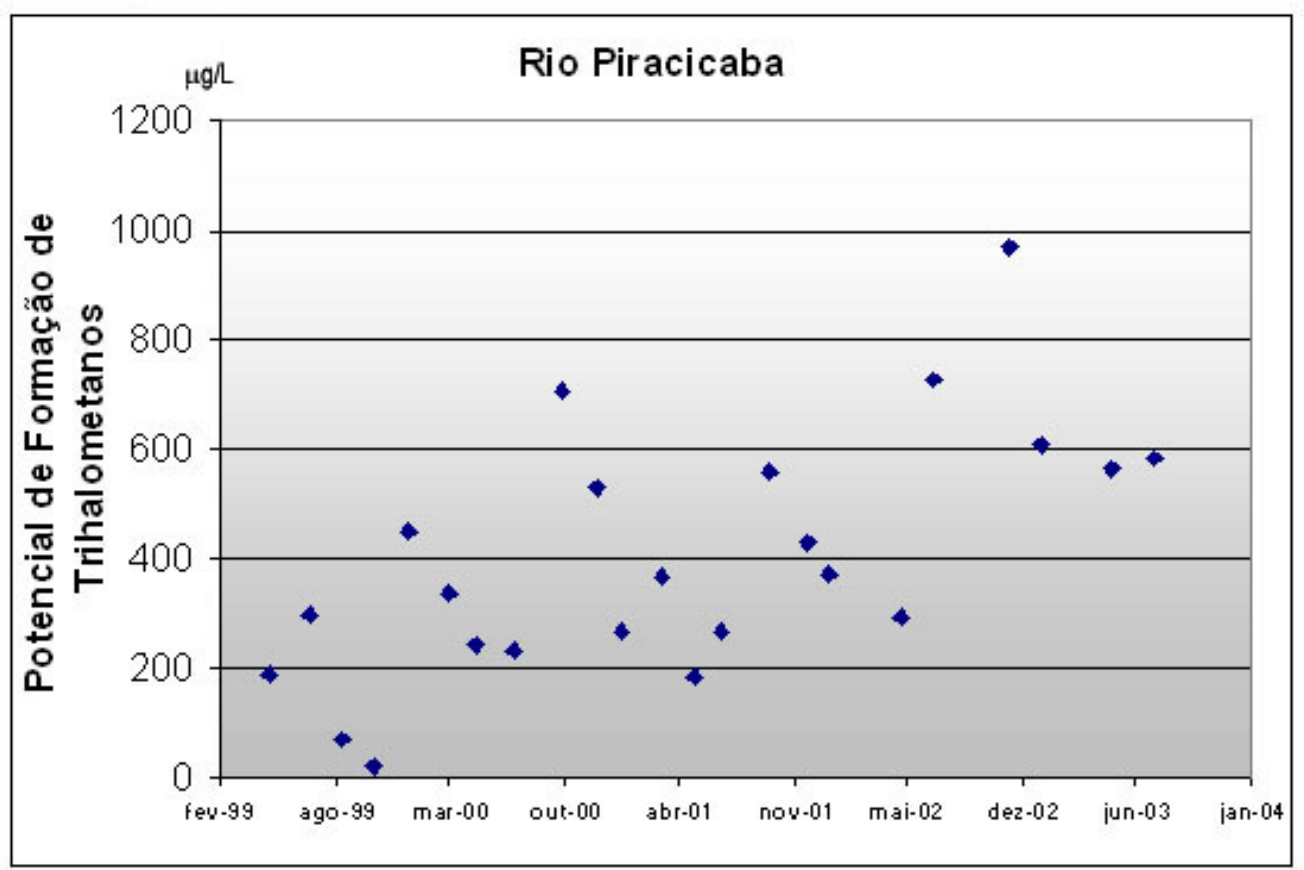

Figura 59- Potencial de formação de THM no rio Piracicaba de 1999 a 2003 no PCAB2220 (captação Fonte: CETESB (2003)

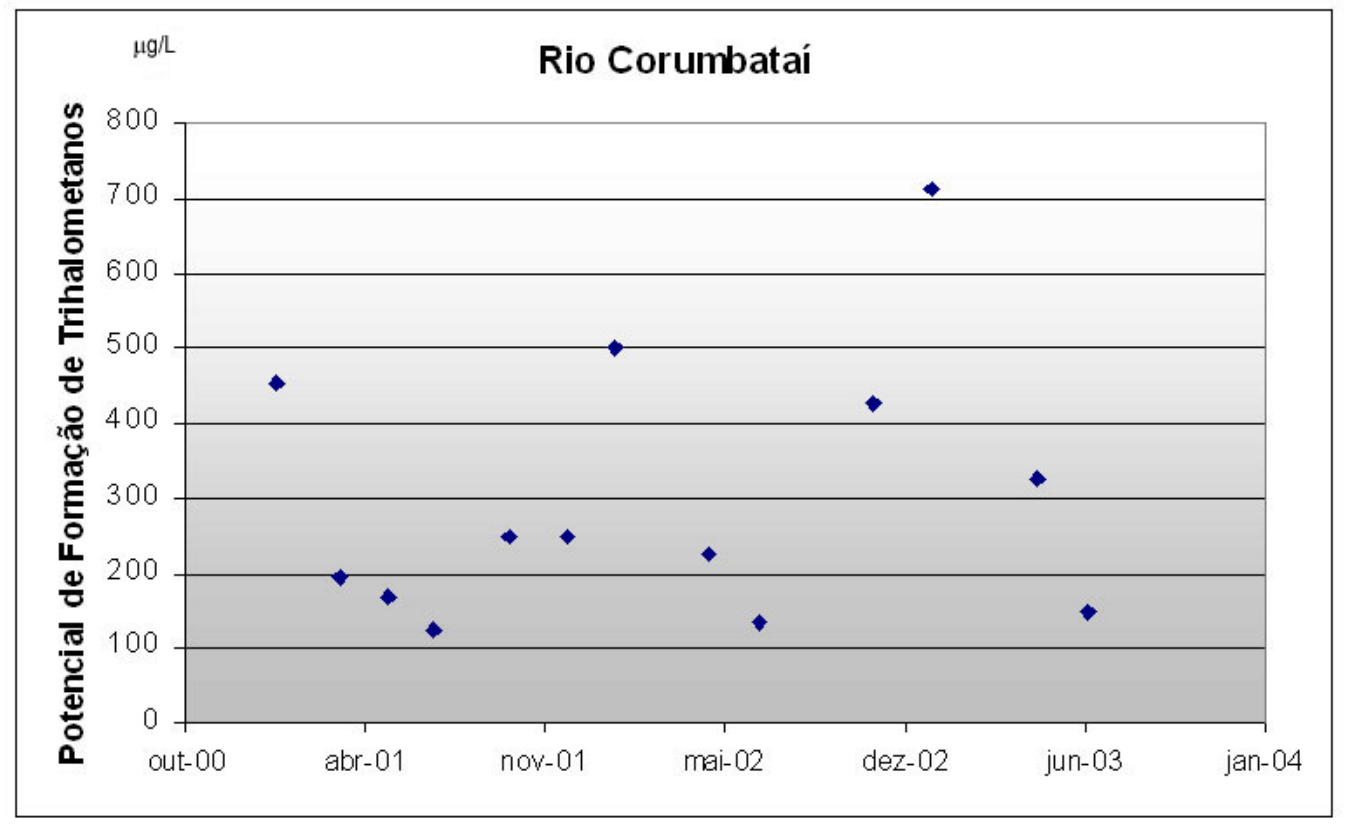

Figura 60- Potencial de formação de THM no rio Corumbataí de 2001 a 2003 no CRUM02500 (captação) Fonte: CETESB (2003) 
O Potencial de formação de THM nos rios Piracicaba e Corumbataí apresentam valores crescentes. No rio Piracicaba a maior parte dos resultados está entre 200 e $800 \mu \mathrm{g} / \mathrm{L}$ e no rio Corumbataí entre 100 e $500 \mu \mathrm{g} / \mathrm{L}$. Conforme já descrito, mananciais de abastecimento com menor concentração de carbono orgânico são considerados de melhor qualidade, pois terão menor demanda de cloro e quantidade menor de produtos decorrentes da desinfecção serão formados na água tratada. O carbono orgânico nos dois corpos d'água provavelmente advém de contribuições antrópicas e crescentes. Entretanto, mananciais com alto percentual de cobertura florestal podem possuir altas contribuições de carbono orgânico advindas do próprio meio. No caso do rio Corumbataí, a observação da contribuição crescente deste parâmetro e a diversidade e complexidade de substâncias introduzidas pelas fontes urbanas, industriais e agrícolas são registros suficientes para alertar aos gestores da água.

A concentração de Giárdia e Cryptosporidium nos dois pontos de monitoramento nas bacias dos rios Piracicaba e Corumbataí estudados estão expressas nas Figuras 61 e 62. 


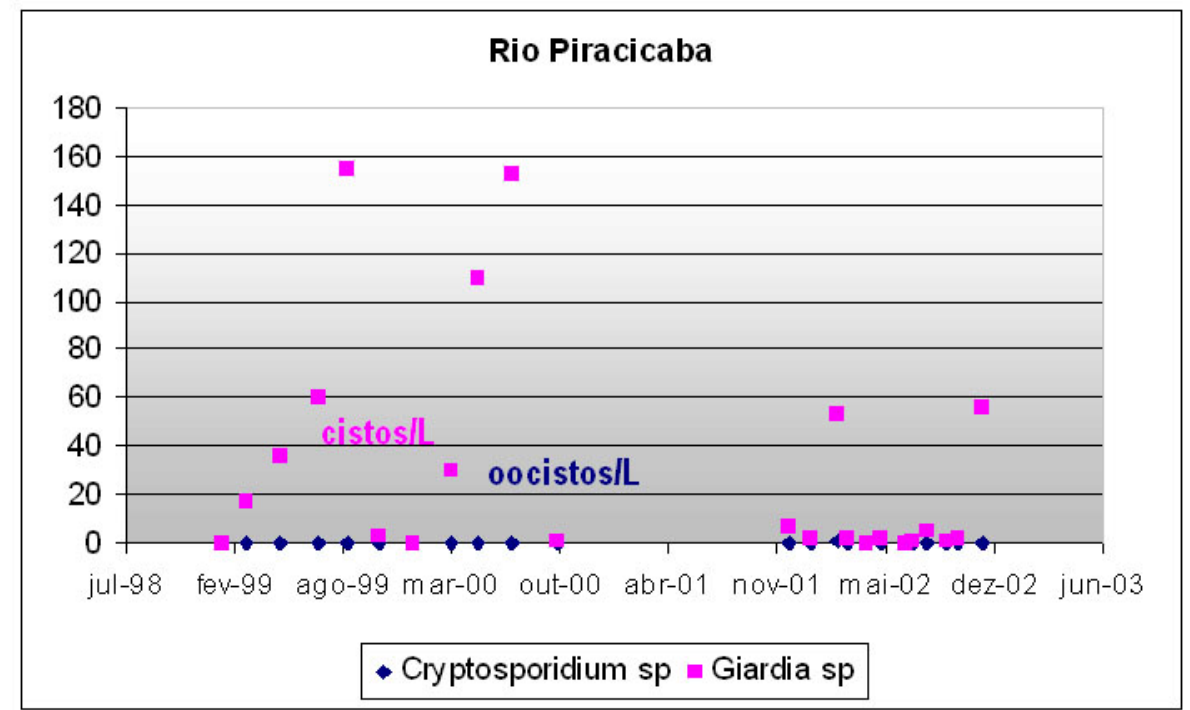

Figura 61- Giardia e Cryptosporidium no rio Piracicaba de 2001 a 2003 no PCAB02220(Captação) Fonte: CETESB (2003)

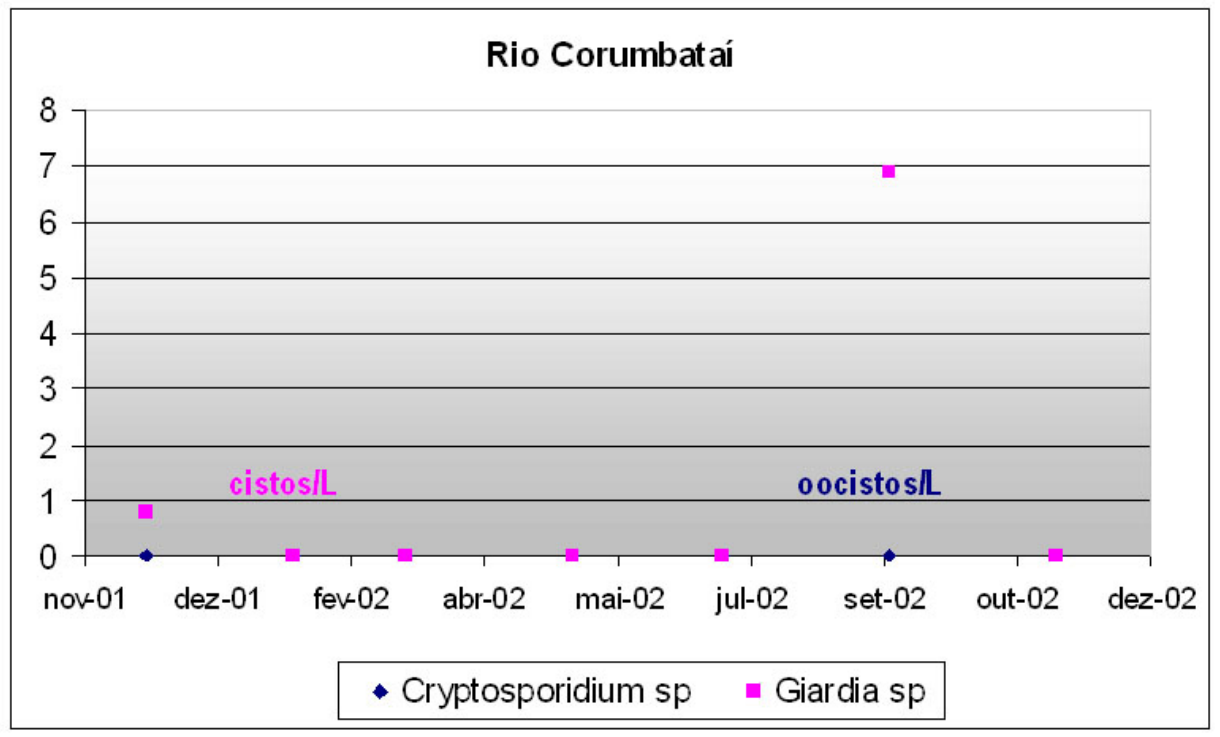

Figura 62- Giardia e Cryptosporidium no rio Corumbataí de 2001 a 2002 no CRUM02500 Fonte: CETESB (2003) 
A concentração de Giardia no rio Piracicaba apresenta valores bem superiores do que aqueles detectados no rio Corumbataí. Considerando que esta categoria de organismos pode não ser removida em estações de tratamento de água para abastecimento público convencionais, a situação merece atenção. O rio Corumbataí possui concentrações de cistos de Giardia menos elevados, entretanto as perspectivas de desenvolvimento dos municípios da bacia podem alterar este quadro.

A concentração de Cryptosporidium nas duas bacias atinge valores entre 0 e 1 oocistos/L. Nos Estados Unidos, em 1996, a EPA estabeleceu o limite de 10 oocistos/L para águas superficiais captadas para o abastecimento público.

O protozoário parasita Cryptosporidium emergiu como um dos mais importantes contaminantes da água responsável por vários surtos de criptosporidiose, afetando mais de 427.000 indivíduos em todo o mundo. Até hoje, pelo menos oito espécies do gênero Cryptosporidium foram descritas, mas somente o C. parvum têm sido associado às doenças gastroentestinais em humanos. A criptosporidiose pode ser fatal para imunocomprometidos e pode debilitar severamente indivíduos imunocompetentes. Os oocistos de Cryptosporidium são resistentes às pressões ambientais, podendo sobreviver por vários meses no ambiente aquático e são também resistentes à desinfecção por cloro utilizada no tratamento convencional de água. $O$ estudo de Muller (2000) teve como objetivos determinar a ocorrência e densidade de Cryptosporidium em amostras de água superficiais e tratadas (após floculação, coagulação, sedimentação, filtração e desinfecção) coletadas em duas Estações de Tratamento de Água da cidade de São Paulo. De um total de 24 amostras analisadas, de cada tipo de água (sendo 12 de cada Estação de Tratamento de Água), os oocistos foram detectados em 75\% das amostras de água bruta e em 12,5\% das amostras de água tratada, quando estas foram concentradas por precipitação química e em 73,91\% das amostras de água bruta e 33,33\% das amostras da água tratada, quando as mesmas foram concentradas pela técnica da membrana filtrante. A densidade de oocistos de Cryptosporidium não apresentou correlação significativa com indicadores microbiológicos e os parâmetros físico-químicos de qualidade da água. Os resultados obtidos sugeriram que o tratamento de água convencional é ineficaz para a remoção de oocistos, ressaltando a necessidade de estabelecer programas de gerenciamento em bacias hidrográficas (mananciais) que efetivamente garantam a baixa densidade de oocistos de Cryptosporidium em águas de mananciais de abastecimento público. 
A implantação de rede de monitoramento biológico na bacia do rio Corumbataí poderia ser uma ferramenta importante para dar indicativos mais fiéis e holísticos da evolução da qualidade das águas. Os parâmetros físico-químicos clássicos de expressão da qualidade das águas têm refletido uma certa "acomodação" do corpo d'água ao longo do tempo, não se observando mudanças drásticas e conclusivas. Por todas as vantagens clássicas da utilização do biomonitoramento, destacando-se a exposição prolongada da biota aos poluentes e a perenidade do registro dos efeitos destes poluentes, há que se vislumbrar o início da utilização deste recurso pelo menos em afluentes mais preservados e importantes da bacia do rio Corumbataí, como o rio Cabeça e o rio Passa Cinco. Estes são afluentes de boa qualidade, entretanto não há monitoramento de suas águas, como também não há perspectiva a curto prazo de planejamento dessas bacias. São mananciais sobre os quais municípios demonstram interesse e enxergam como uma outra alternativa para abastecimento público, que é o caso de Piracicaba na eventualidade de o rio Corumbataí apresentar comprometimento que justifique lançar mão de tal alternativa.

\subsubsection{Reflexão sobre arranjo das instituições e legislação vigentes na bacia do rio Corumbataí e do rio Piracicaba}

As instituições responsáveis pela gestão das águas das bacias dos rios Piracicaba e Corumbataí instalaram-se na região em meados da década de 80. Desde então, pode-se constatar que o desenvolvimento econômico dos municípios e o crescimento demográfico registrados para as duas bacias e medidos através das variáveis relatadas neste estudo não deixou mais de apresentar índices crescentes. A velocidade da ocupação da bacia nos seus mais diversos segmentos econômicos vêm se mostrando mais eficiente do que a estrutura montada pelo poder público para administrá-la. Paralelamente a isto, a sociedade civil organizada atualmente está mais capacitada para exigir do poder público medidas que venham reduzir o impacto sobre os recursos naturais das bacias, particularmente a água. No entanto, este segmento enfrenta ainda inúmeros problemas relacionados à sua manutenção, capacidade de organização, informação sobre a real situação do meio e possibilidade de participação mais perene nos fóruns oficiais de discussão.

As bacias dos rios Piracicaba e Corumbataí são institucionalmente 
bastante organizadas, com comitê de bacias instalado e operante, com representação de regionais da CETESB, DEPRN, DAEE, Polícia Ambiental, Promotoria Pública, Casa da Agricultura, Vigilância Sanitária, dentre outros órgãos que contribuem com a gestão da água. Todavia com a qualidade de parte significativa de seus corpos d'água comprometida, particularmente para o abastecimento público, o mais nobre uso atribuído a um rio. Sobre a estrutura estabelecida para estas instituições pesa-se a crítica da desarticulação e segmentação das ações, como por exemplo a responsabilidade sobre a fiscalização da qualidade das águas, que pertence à CETESB e sobre a quantidade, que é delegada ao DAEE. De fato, esta desarticulação provoca prejuízos cujas soluções algumas vezes são perseguidas no comitê de bacias $\mathrm{CBH} / \mathrm{PCJ}$. É o caso da criação da Câmara Técnica de Outorgas e Licenças (CTOL), que discute o licenciamento integrado na bacia, ou da Câmara Técnica de Monitoramento Hidrológico, que regularmente reúne-se para gerenciar a operação de vazões do Sistema Cantareira e outros problemas relacionados ao tema. Ocorre que o comitê de bacias não possui ainda uma agência de bacias, que permitirá dar caráter executivo às suas deliberações e, portanto, o encaminhamento de suas decisões é sempre bastante lento e não acompanha a velocidade de degradação da bacia. Ainda assim, a estrutura do comitê de bacias e todas as suas instâncias são parte da esperança de avanço sobre o planejamento do desenvolvimento da bacia e a reversão de quadros ambientais indesejáveis.

A legislação que sustenta toda essa estrutura de instituições é forte e bastante completa, mas talvez as ferramentas técnicas e/ou tecnológicas que as permitam atuar de forma mais eficaz estejam necessitando de reforços, bem como o volume do corpo técnico destas instituições. Nessas bacias, exatamente porque a velocidade do desenvolvimento não foi compatível com a capacidade do Estado e de outras instâncias de se anteciparem a ele, é que o meio se ressentiu e no caso do objeto deste estudo, os rios perderam qualidade e até capacidade de provisão. Uma das dificuldades em termos de controle corretivo/preventivo da Agência Ambiental do Estado de São Paulo é que comumente é impossível exigir da empresa o atendimento a padrões de qualidade do corpo receptor, conforme a classe do rio prevista na legislação vigente, visto que este ao passar pela empresa já tem os valores de seu padrão de qualidade ultrapassado. Diante da dificuldade de cobrar do empreendimento o atendimento ao padrão de qualidade do corpo receptor, resta à Agência Ambiental do 
Estado de São Paulo exigir o atendimento aos padrões de emissão. O que passa a ocorrer então é uma constante violação da capacidade de autodepuração do corpo receptor, em decorrência do lançamento de cargas poluidoras.

A sociedade civil possui cada vez mais acesso às estruturas estabelecidas em diversas esferas de decisão e aos dados produzidos nos órgãos do Estado, que gera boa parte das informações relacionadas à questão ambiental e no caso deste estudo, informações relacionadas à qualidade dos mananciais. Todavia, os dados não necessariamente traduzem-se em informações para a sociedade leiga, porém organizada. Este é um fator que contribui com a centralização da informação dentro do meio técnico, que salvo exceções, está concentrada nas instituições do próprio Estado, gerador dos dados. A representação da sociedade civil no Comitê de Bacias é bastante heterogênea em termos de interesses, o que dificulta ainda mais o jogo de forças dentro dos fóruns de debate e decisão. Observando sobre esta ótica vêse a importância do Estado neste processo no que diz respeito à difusão de informações e à formação de cidadãos com consciência ambiental.

A UGRHI 05 do Estado de São Paulo possui dois Comitês, o Estadual, que atua desde 1993 e o federal, que atua desde 2003. Na prática, desde 2003, reúnese o Comitê Federal e suas composições de membros foram adaptadas ao que prevê a legislação federal. A divisão de representantes nos Comitês Federais é definida da seguinte forma: membros da União, dos municípios situados no todo ou em parte de sua área de atuação, dos usuários das águas, das entidades civis de recursos hídricos com atuação comprovada na bacia e o número de representantes dos poderes executivos(União, Estado, Distrito federal e Municípios) restringe-se à metade do total de membros. Nos Comitês Federais paulistas, a divisão de membros era estabelecida com 1/3 para os municípios, 1/3 para o Estado e 1/3 para a sociedade civil, segmento que abriga interesses diversos. Seja qual for a composição do Comitê de Bacias, persiste o problema sobre a criação e a divulgação da informação.

Os interesses econômicos freqüentemente divergem dos interesses ambientais e neste caso a consciência e participação da sociedade civil pode definir posicionamentos menos comprometidos dos Comitês de bacias. Seria importante que o Estado fizesse campanhas mais diretas quanto à criticidade dos mananciais de abastecimento público, o que estimularia a organização da população.

Paralelamente a esta preocupação, é importante destacar a evolução da 
legislação sobre o controle das águas de abastecimento público expressa na Portaria Federal do Ministério da Saúde 518/2004, que fez alterações pequenas sobre a Portaria 1469 de 2001. A Portaria 518/2004 estabelece pela primeira vez a responsabilidade das companhias de água sobre a escolha e/ou a qualidade de seus mananciais, observando-se a ocupação da bacia e a associação entre agravos à saúde e situações de vulnerabilidade do sistema. Dentre outras providências ela aumenta a quantidade de parâmetros a serem monitorados nas águas de abastecimento e prevê a obrigatoriedade de prestação de informações regulares aos consumidores sobre os seguintes aspectos: a) descrição dos mananciais com informações sobre disponibilidade hídrica e qualidade das águas; b) estatística descritiva dos valores de parâmetros de qualidade detectados na água, seu significado, origem e efeitos sobre a saúde; c) ocorrência de não conformidades com o padrão de potabilidade e as medidas corretivas providenciadas; d) manter registros atualizados sobre as características da água distribuída e disponibiliza-los à consulta pública.

Sabe-se que há diversos problemas sobre a aplicabilidade desta Portaria, dentre os quais a incapacidade de muitos municípios de sustentarem uma estrutura capaz de fornecer todas essas informações. Esta dificuldade pode tornar a Portaria ineficaz e o avanço que ela vislumbra pode não se concretizar.

Atualmente os municípios enfrentam restrições econômicas, em parte pelo aumento da responsabilidade sobre diversos setores que tradicionalmente foram atribuição do Estado. Por outro lado muitos municípios não priorizaram historicamente o tratamento de esgotos e tampouco se sentem responsabilizados pela manutenção da qualidade das águas de seu manancial de abastecimento público. Usualmente esta responsabilidade é atribuída à CETESB, que por sua vez é incapaz de atender a esta demanda, pois ela depende, e muito, de planejamentos integrados, sobre os quais a participação do poder municipal é fundamental.

A ausência de verbas dos municípios para assuntos relativos ao meio ambiente é na atualidade timidamente suprida em parte pelo Fundo Estadual de Recursos Hídricos (FEHIDRO). Os comitês de bacias recebem pequeno montante de verbas que são repassadas a diferentes projetos eleitos, através de critérios de priorização de cada comitê, dentre os quais se inclui o tratamento de esgotos urbanos. A implementação da cobrança pelo uso da água associada à criação da Agência de Bacias deve implicar na entrada mais significativa de recursos e na perspectiva de 
atuação mais efetiva da estrutura do Comitê de Bacias.

A Agência Nacional de Águas (ANA), órgão federal recentemente criado e que de certa forma centralizou a discussão e a prática sobre a gestão e a cobrança do uso da água, também possui programa de destinação de verbas aos municípios, destacando-se aquele que paga pelo esgoto tratado. Neste caso, a companhia de águas necessita ter verba para tratar os esgotos, o que para a maior parte dos municípios inviabiliza o acesso a essa fonte de recursos.

A atual estrutura das instituições e respectivas atribuições muitas vezes não permitem que diferentes órgãos sejam administrativamente capazes de frear processos de desenvolvimento que sejam impactantes ao meio, particularmente aos mananciais de abastecimento público.

Na bacia do rio Piracicaba, recentemente, o município de São Pedro aprovara um loteamento residencial de grande extensão exatamente a montante da captação principal do município vizinho de Águas de São Pedro, cujo serviço de águas e esgoto é administrado pela SABESP. No processo administrativo transitado dentro do Grupo de Análise de Projetos Habitacionais (GRAPROHAB), a CETESB apontou o problema e tentou conduzi-lo de forma a que as partes interessadas buscassem solução que retirasse o lançamento de esgotos tratados do manancial. Vale ressaltar que uma das condições para aprovação de loteamentos residenciais é a condição de tratamento dos esgotos a serem gerados, que pode ser considerada aceitável desde que o loteador implante tratamento de esgotos próprio, ou desde que o município possua tratamento ou Termo de Ajustamento de Conduta (TAC) com a CETESB ou com a Promotoria Pública para tratamento dos esgotos urbanos. Neste caso, o loteamento propôs uma sofisticação do sistema de tratamento, que incluía a cloração dos esgotos tratados, procedimento desinteressante, porém aceito pela CETESB, considerando-se a presença de captação de águas para abastecimento público a jusante do lançamento de esgotos tratados. A SABESP por outro lado alegou não possuir investimentos para transportar o esgoto tratado para outro corpo receptor. Assim, o loteamento foi aprovado e as instituições demonstraram pouca sensibilidade na ação de privilegiar processos preventivos de conservação de mananciais e associar este tipo de evento aos riscos oferecidos à saúde da população que será abastecida por este manancial.

Na bacia do rio Corumbataí, o município de Santa Gertrudes está com sua captação de águas para abastecimento público ameaçada por um adensamento de 
extrações de argila que tem por objetivo abastecer parte das indústrias do maior pólo cerâmico do Brasil, que produz grande metragem de pisos e revestimentos cerâmicos. O município de Santa Gertrudes não se opôs ou impôs qualquer restrição à atividade extrativa e de secagem de argila nas cabeceiras do córrego Santa Gertrudes que abastece quase a totalidade do município. As características geológicas da região não favorecem a utilização de águas subterrâneas para o abastecimento público. Estudos preliminares demonstraram que a vazão de captação do município já é superior à vazão mínima Q 7,10 do córrego Santa Gertrudes. O aprofundamento das cavas extrativas abaixo das cotas das APP e de projeto originalmente aprovado pelo Sistema Ambiental do Estado, a elevada turbidez e a alta concentração de sólidos nas águas do córrego Santa Gertrudes, a jusante do adensamento, motivaram a paralisação das atividades. O Sistema Ambiental sofreu diversas pressões inclusive do município para o retorno do funcionamento das áreas extrativas. Esta situação mostra o distanciamento do município da sua responsabilidade sobre a conservação do seu manancial de abastecimento público.

O Ministério Público é outro ator institucional que tem papel fundamental nas ações ambientais e que está mais distante das pressões diretas comumente sofridas pelo Município e até por órgãos administrativos. A Lei de Crimes Ambientais veio fortalecer o peso das ações administrativas e trata-se de importante ferramenta no processo de desenvolvimento das ações ambientais.

Desde dezembro de 2002, o Sistema Ambiental conta com importante instrumento de controle sobre as fontes pontuais de poluição que se refere ao licenciamento renovável. Até esta data as licenças de operação eram perenes. A renovação possibilita ao Sistema Ambiental o estabelecimento de condicionantes impostas às fontes de poluição pontuais, o que pode efetivamente favorecer a conservação de mananciais.

As fontes difusas de poluição estão em parte relacionadas com atividades agrícolas. As bacias dos rios Piracicaba e Corumbataí possuem grande parte de suas terras ocupadas pelo cultivo de cana-de-açúcar e pastagens. As ações de controle estão fundamentalmente concentradas sobre a Secretaria da Agricultura e seus órgãos, mas não se observa comprometimento de programas com a prevenção a fontes de poluição desta natureza. É um grande desafio colocado para as instituições que buscam a conservação dos recursos hídricos nestas bacias. 
O Comitê de Bacias CBH-PCJ recentemente, em 01.07.2004, a pedido do SEMAE/Piracicaba, em iniciativa inédita, criou o Grupo de Trabalho da bacia do rio Corumbataí (GT-Corumbataí), no âmbito da Câmara Técnica do Plano de Bacias (CTPB). O GT-Corumbataí terá a atribuição de propor as ações e os investimentos necessários para a recuperação e conservação dos recursos hídricos da bacia hidrográfica do rio Corumbataí, para que constem do Plano das Bacias Hidrográficas dos rios Piracicaba, Capivari e Jundiaí - período de 2004 a 2007.

A criação deste Grupo é um registro importante na busca da sustentabilidade da bacia. O envolvimento do município de Piracicaba, grande interessado na manutenção da boa qualidade do rio, é fundamental para provocar as instituições a atentarem para a gravidade da situação de degradação dos recursos hídricos da bacia. O município tem seu papel a cumprir na conservação dos recursos hídricos e que é importantíssimo, mas ele também deve exercer o importante papel de provocador das instâncias estaduais e federais.

O estabelecimento de políticas públicas que ofereçam aos municípios menos industrializados possibilidades de crescimento econômico através do desenvolvimento de outras atividades que gerem riqueza, inclusive voltadas à conservação dos recursos hídricos, mostra-se como saída importante para proteger a bacia do rio Corumbataí do desenvolvimento desenfreado e que não respeita a capacidade suporte do meio. 


\section{CONCLUSÕES}

A importância do percentual de cobertura florestal em um manancial de abastecimento público, associado aos fatores custo do tratamento e risco à saúde, preenchem uma importante lacuna nas discussões sobre gestão de recursos hídricos. A qualidade das águas é perseguida pelos serviços de água sem que, no entanto, haja o entendimento da grandeza do que isso representa. Poucos trabalhos nacionais abordam questões associadas ao risco à saúde decorrente da utilização de mananciais de qualidade comprometida. A escassez de água nas regiões mais adensadas resulta no aproveitamento de mananciais com baixo índice de qualidade, perpetuando a tradição incorporada em nossas instituições e sociedade de que o tratamento convencional das águas é capaz de torná-la potável. As soluções de engenharia civil não são isoladamente as únicas intervenções importantes em uma bacia de abastecimento público. Elas devem estar associadas a inúmeras outras medidas de manejo, dentre as quais merece destaque a elevação do percentual de cobertura florestal da bacia.

A rejeição do rio Piracicaba como principal manancial de abastecimento público de Piracicaba demonstrou que a utilização de obras de engenharia civil como recurso único para obter água potável não é uma verdade absoluta. O SEMAE, que sofreu todas as conseqüências de operar o tratamento abastecido por um manancial comprometido, mostrou ser uma companhia com visão técnica, contratando um estudo junto ao IPEF para dar diretrizes para a recuperação florestal da bacia do rio Corumbataí.

O valor que a cobertura florestal impõe ao manancial de abastecimento público, que embute aspectos de risco à saúde e custos de tratamento da água, deve ser gradativamente reconhecido pelas autoridades e pela sociedade civil. A primeira maneira de reconhecer seu valor é refletir sobre 
ela. Assim, a utilização do percentual de cobertura florestal de uma bacia de abastecimento público como primeiro indicativo da qualidade das águas dessa bacia e de seus reflexos sobre os custos do tratamento de suas águas foi considerada pertinente.

Os custos específicos operacionais das ETAs referentes ao uso da energia elétrica, de produtos químicos e o volume de lodo gerado em uma ETA, associados a dados médios de qualidade dos mananciais de captação, podem se prestar ao papel de indicadores iniciais da condição de ocupação e de manejo da bacia de drenagem do manancial em estudo.

Observa-se que não foi realizado estudo de vulnerabilidade de solos de cada bacia estudada, nem tampouco houve distinção entre os sistemas de represa ou rios. Considera-se que, independentemente da fragilidade do solo, ou das características do leito de drenagem, o manancial de abastecimento público é uso nobre da água e sua preservação deve ser perseguida, verificando-se as peculiaridades de cada sistema.

A relação do custo específico de produtos químicos na ETA com o percentual de cobertura florestal da bacia de abastecimento foi a relação mais regular obtida dentre os segmentos de custos específicos analisados. Para seis dos sete sistemas e ETAs estudadas, o custo específico com produtos químicos na ETA elevase com a redução do percentual de cobertura florestal da bacia de abastecimento. Dentre os sistemas e ETAs estudadas, o rio Piracicaba, cuja bacia possui o menor percentual de cobertura florestal, tem o maior custo de uso específico de produtos químicos.

Essa informação pode contribuir no atual conflito pelo uso da água existente na bacia do rio Piracicaba, onde o Sistema Cantareira que reverte as águas da bacia do rio Piracicaba retém as águas de melhor qualidade, de menor risco à saúde e de tratamento mais barato, enquanto que as águas do rio Piracicaba, que sofrem também com a afluência de baixas vazões do Sistema Cantareira, têm problemas de qualidade para serem tratadas, maior risco à saúde e alto custo de tratamento.

O custo específico de tratamento (custo $/ 1000 \mathrm{~m}^{3}$ água com produtos químicos e energia elétrica da ETA) das águas do rio Piracicaba é 12,7 vezes superior 
ao custo específico correspondente das águas do Sistema Cantareira. Destacando-se o aspecto da cobertura florestal como um primeiro indicativo de saúde da bacia, sobre o qual se buscou associação neste estudo, destaca-se que a bacia do Sistema Cantareira possui $27,16 \%$ de sua área com cobertura florestal e a bacia do rio Piracicaba possui apenas 4,30 \%. Estes dados podem servir como um elemento importante na discussão da cobrança pelo uso da água e na parcela de responsabilidade que cabe a cada parte envolvida.

A associação da qualidade das águas ao risco de ocorrência de danos à saúde humana vem sendo seriamente discutida e a prevenção e o monitoramento são duas ações fundamentais para a redução desse risco. A conservação de mananciais de abastecimento público através do aumento da cobertura florestal, principalmente contemplando os rios de menor ordem, define uma ação preventiva fundamental para a redução de riscos à saúde. O monitoramento dos rios deve estar associado à possibilidades de ações, ou estará apenas registrando dados, não transformados em informação que possam trazer benefícios ao meio.

O advento da Portaria Federal do Ministério da Saúde 518 de 2004, que substituiu a Portaria 1469 de 2001, contribuiu muito com a busca pelo aprimoramento dos sistemas de abastecimento de água; no entanto, são inúmeros os obstáculos a serem superados diante da precariedade das estruturas de muitos serviços municipais de água.

No que se refere aos custos de tratamento de água e à qualidade dos mananciais, sabe-se da importância da localização geográfica da cobertura florestal em cada bacia, assim como das interferências da ocupação do solo, tipo do solo, geomorfologia e geologia predominantes, mas o estudo não possuía esta proposta e sugere-se que esta possa ser uma nova investigação a ser feita em algumas das unidades estudadas.

As perspectivas sobre a bacia do rio Corumbataí são de ocupação indiscriminada e acelerada, mesmo considerando-se os mecanismos institucionais e legais existentes. A média das taxas geométricas de crescimento anual da população total dos municípios para as bacias dos rios Piracicaba e Corumbataí, nos períodos de 91/00 e 00/02, são maiores do que a taxa média obtida para a Região Administrativa de Campinas. A mesma taxa para os dois períodos é maior para a bacia do rio Corumbataí, do que para a bacia do rio Piracicaba, indicando, no mínimo, uma 
ocupação similar para as duas bacias. No que se refere à existência de Plano Diretor para uso e ocupação do solo, em 1997, 71 \% dos municípios da bacia do rio Corumbataí não possuíam este instrumento.

Se consideradas as semelhanças dos índices sócio-econômicos e do meio físico, entre as bacias do rio Piracicaba e do rio Corumbataí, a expectativa sobre a qualidade das águas do rio Corumbataí a médio e longo prazo é de queda para alguns parâmetros importantes. O IAP já é considerado ruim e reflete a posição oficial do órgão de controle da qualidade das águas do Estado de São Paulo. Em contrapartida, as iniciativas do Estado para colaborar com os municípios na reversão deste quadro resumem-se às intervenções localizadas dos órgãos de controle estaduais e do Comitê de Bacias CBH-PCJ, que possui ação muito limitada, ainda ligada de forma preponderante ao diagnóstico e planejamento de ações.

Não se pode isentar os municípios da imensa responsabilidade sobre a gestão de seu território e sobre a priorização de seus recursos, já que grande parte deles destina pouca verba ao tratamento dos esgotos urbanos. Os municípios estão em geral bastante despreparados para assumirem responsabilidades sobre o planejamento de seu crescimento e para administrarem suas próprias demandas ambientais. Há poucos recursos, poucos técnicos qualificados e despreparo da estrutura para conduzir questões básicas como tratamento de esgotos e disposição adequada de resíduos sólidos urbanos.

As instituições responsáveis por políticas de comando e controle não estão satisfatoriamente articuladas com a missão do Comitê de bacias $\mathrm{CBH} / \mathrm{PCJ}$, bastante preocupadas ainda com sua própria missão. Estas instituições muito pouco conseguem interferir no meio, pois, dentre outras razões, não dispõem de instrumentos legais para fazê-lo.

Os municípios da bacia do rio Corumbataí não apresentaram, ao longo do estudo, características, que na média diferenciassem a evolução do seu comportamento ao longo dos anos, daquele observado para os municípios da bacia do rio Piracicaba. Esta constatação era previsível e serve de alerta às autoridades quanto às conseqüências ambientais esperadas para a bacia. Em escala de tempo inferior a 40 anos, o rio Piracicaba foi abandonado como principal manancial de abastecimento público do município de Piracicaba, tratando-se de situação de difícil reversão.

Considerando-se a importância histórica do rio Piracicaba e o fato de ser 
ele um símbolo para a região, as instituições deveriam considerar a reversão do seu atual quadro de poluição como uma prioridade a ser perseguida.

\subsection{Recomendações}

Considerando-se a importância da conservação de mananciais de abastecimento público, recomenda-se:

- O estabelecimento de Áreas de Proteção e Recuperação dos Mananciais (APRMs) pelo $\mathrm{CBH}-\mathrm{PCJ}$, a fim de dar o primeiro passo para a proteção planejada da bacias de abastecimento público, como a bacia do rio Corumbataí, e definir regras para as diferentes possibilidades de ocupação.

- O incremento de recursos financeiros voltados à gestão de recursos hídricos, aumento da velocidade do cumprimento dos Termos de Ajustamento de Conduta celebrados por municípios com a CETESB e o Ministério Público para o tratamento de $100 \%$ dos esgotos urbanos, a cobrança da sociedade civil e o fortalecimento dos órgãos ambientais responsáveis pelo controle sobre os recursos hídricos.

- Que o Plano Diretor de Conservação de Recursos Hídricos elaborado pelo IPEF \& SEMAE (2001) para a bacia do rio Corumbataí ganhe visibilidade, seja aprimorado e implantado, com a cooperação da Federação, do Estado e de todos os municípios envolvidos na bacia.

- A busca de instrumentos e verbas que possam favorecer a aptidão rural e turística de alguns municípios da bacia do rio Corumbataí, como a regulamentação da Lei que define a Área de Proteção Ambiental (APA) Corumbataí.

- A garantia da articulação entre políticas setoriais e a participação de agentes locais, que vêem na legislação um impeditivo para o desenvolvimento da região, nos processos de decisão sobre os usos das áreas e dos mecanismos de conservação.

- O estabelecimento de índices municipais utilizados para o estabelecimento de políticas públicas estaduais que reflitam também a capacidade suporte dos 
recursos hídricos associados aos municípios.

- A compensação financeira de proprietários rurais que definam áreas de conservação, cooperando com planos de conservação florestal estabelecidos para a bacia hidrográfica.

- A divulgação de informações sobre a qualidade dos recursos hídricos e das reuniões periódicas do Comitê de Bacias e suas Câmaras em meios de comunicação populares.

- A fiscalização e cooperação das instituições para o cumprimento da Portaria Federal do Ministério da Saúde 518/2004.

- Licenciamento diferenciado para empreendimentos que pretendam se instalar em bacias de abastecimento público. 


\section{REFERÊNCIAS BIBLIOGRÁFICAS}

ABUD-ZEID, M. A. Water and sustainable development: the vision for the world water, life and the environmental. Water Policy, n.1., p.9-19, 1998.

AGUJARO, L.F.; ISAAC, R. L. Ocorrência de cianobactérias potencialmente tóxicas nas bacias dos rios Piracicaba, Capivari e Jundiaí - Estado de São Paulo - Brasil e avaliação dos corpos d'água em relação à eutrofização. In: CONGRESSO INTERAMERICANO DE INGENERIA SANITÁRIA Y AMBIENTAL, 28., Cancun, 2002. Anais. Cancun, 2002. p. 1-8.

ALLAN, J. D.; JOHNSON, L.B. Catchment-scale analysis of aquatic ecosystems, Freshwatwer Biology, n.37, p.107-111, 1997.

ALLAN, J.D.; ERIKSON, D.L.; FAY, J. The Influence of catchment land use on stream integrity across multiple spatial scales. Freshwater Biology,. n.37, p.149-161, 1997.

BATALHA, B.H. Ameaça microscópica na água potável. Revista Ciência Hoje, v. 25, n. 145, p.28-35, 1998.

BETING, J. Mais rico e mais justo.

http://www2.uol.com.br/aprendiz/n_colunas/j_betting/id220301.htm / (24 fev. 2004).

BRAGA, B.; PORTO, M.; TUCCI,C.E.M. Monitoramento de quantidade e Qualidade das Águas. In: REBOUÇAS, A.C.; BRAGA, B.; TUNDISI, J.G. (Org.). Águas doces no Brasil capital ecológico, uso e conservação. São Paulo: Instituto de Estudos Avançados da USP, 1999, p.249-304. 
BRAGA, R. Plano Diretor Municipal: três questões para discussão. Caderno do Departamento de Planejamento, Faculdade de Ciências e Tecnologia, v.1, n.1, p.15-20, 1995.

BRANCO, S.M.. Água, Meio Ambiente e Saúde. Águas Doces no Brasil Capital Ecológico, Uso e Conservação. In: REBOUÇAS, A.C.; BRAGA, B.; TUNDISI, J.G. (Org.). Águas doces no Brasil capital ecológico, uso e conservação. São Paulo: Instituto de Estudos Avançados da USP, 1999, p.227-247.

BRASIL - Ministério do Planejamento e Orçamento/ SEPURB - Secretaria de Política Urbana/ Governo do Estado de São Paulo/ SHRSO - Secretaria de Recursos Hídricos, Saneamento e Obras/ CBH-PCJ - Comitê das bacias hidrográficas dos rios Piracicaba, Capivari e Jundiaí. Programa de Investimentos para Proteção e Aproveitamento dos Recursos Hídricos das Bacias dos rios Piracicaba, Capivari e Jundiaí. São Paulo: DAEE, 1999. 76p.

CHANSHENG, H.; MALCOLM, S.B.; DAHLBERG, K.A.; FU, B. A conceptual framework for integrating hydrological and biological indicators into watershed management. Landscape Ecology and Urban Planning, v.49, p.25-34, 2000.

COMITÊ DAS BACIAS HIDROGRÁFICAS DOS RIOS PIRACICABA, CAPIVARI E JUNDIAÍ. Publicação do Comitê das Bacias Hidrográficas dos Rios Piracicaba, Capivari e Jundiaí: implantação, resultados e perspectivas. São Paulo, 1996. 75p.

COMITÊ DAS BACIAS HIDROGRÁFICAS DOS RIOS PIRACICABA, CAPIVARI E JUNDIAÍ. Plano de bacia hidrográfica 2000-2003: Síntese do relatório final. Piracicaba-SP: DAEE, 2000. 61p.

COMITÊ DAS BACIAS HIDROGRÁFICAS DOS RIOS PIRACICABA, CAPIVARI E JUNDIAÍ. Relatório de situação dos recursos hídricos das bacias hidrográficas dos rios Piracicaba, Capivari e Jundiaí: Relatório Zero. Piracicaba-SP: DAEE, 2000. 490p.

COMPANHIA ESTADUAL DE TECNOLOGIA DE SANEAMENTO AMBIENTAL. Relatório de qualidade das águas interiores do Estado de São Paulo 1999. São Paulo: CETESB, 2000. 391p.

COMPANHIA ESTADUAL DE TECNOLOGIA DE SANEAMENTO AMBIENTAL. Relatório de qualidade das águas interiores do Estado de São Paulo 2002. São Paulo: CETESB, 2003. 402p. 
COMPANHIA ESTADUAL DE TECNOLOGIA DE SANEAMENTO AMBIENTAL. Relatório de qualidade das águas interiores do Estado de São Paulo 2003. São Paulo: CETESB, 2004. 273p.

COMPANHIA ESTADUAL DE TECNOLOGIA DE SANEAMENTO AMBIENTAL E DEPTO. DE ECOLOGIA GERAL, INSTITUTO DE BIOCIÊNICAS, USP. Uso de Índices Biológicos no Biomonitoramento de ambientes aquáticos continentais - riachos e corredeiras na bacia hidrográfica do rio Atibaia. Projeto de Pesquisa FAPESP. Relatório Final. Programa Pesquisa em Políticas Públicas. São Paulo: CETESB, 2000. $112 \mathrm{p}$.

CROUCH, E. A. C.; WILSON, R.; ZEISE, L. The Risks of Drinking Water. Water Resources Research, v.19, n.6, p.1359-1375, 1983.

DAVIES, J. ; MAZUMDER, A. Health and environmental policy issues in Canadá: the role of watershed management in sustaining clean drinking water quality at surface sources. Journal of Environmental Management, n.68, p.273-286, 2003.

DEMOGRAPHIC BULLETIN. Latin America: projection of urban-rural population. Santiago, n.63, jan. 1999. 32 p.

FERRAZ, F.F.B. Dinâmica dos sedimentos em suspensão na bacia do rio Piracicaba. Piracicaba, 2002. 108p. Tese (Doutorado) - Centro de Energia Nuclear na Agricultura, Universidade de São Paulo.

FERRAZ, F.F.B.; CARON, D. Urbanização e expansão agrícola. In: FERRAZ, E. S. B.; MARTINELLI, L. A.; VICTÓRIA, R.L. Coletânea do Notícias Piracena: a bacia do rio Piracicaba. Piracicaba: C.N.Editoria, 2001. p. 63-66.

FISCHER, E.G. Proposição e aplicação de metodologia de gerenciamento integrado dos rios Corumbataí e Passa Cinco da bacia do Piracicaba por meio de banco de dados georeferenciados e modelagem matemática. Piracicaba, 2003. 110p. Tese (Doutorado) - Centro de Energia Nuclear na Agricultura, Universidade de São Paulo.

FORD, T.E.; MAC KENZIE, W.R. How safe is our drinking water? Postgraduate Medicine Journal, n.108, 2000. http://www.postgradmed.com/issues/2000/09_00/ (20 out. 2003). 
FUNDAÇÃO PREFEITO FARIA LIMA -Centro de estudos e Pesquisas da Administração Municipal . http://www.cepam.sp.gov.br/v10/boletim/ (24 fev. 2004).

FUNDAÇÃO SISTEMA ESTADUAL DE ANÁLISE DE DADOS. Informações dos municípios paulistas. http://www.seade.sp.gov.br/ (15 jul. 2003).

GARCIA, L.B.R. Ocupação e Desenvolvimento Econômico da Bacia do Corumbataí Séculos XVIII a XX. http://www.unesp.rc.br/igce/ceapla/atlas/ (15 jun. 2004).

GUO, Z.; XIAO, X.; GAN, Y.; ZHENG, Y. Ecosystem functions, services and their values a case study in Xingshan County of China. Ecological Economics, v.38, p.141-154, jan. 2001.

HAMILTON, L. ; CASSELLS, D. Hydrology overview. In: WORLD BANK ; WWF ALLIANCE FOR FOREST CONSERVATION AND SUSTAINABLE USE. Running pure the importance of forest protected areas to drinking water. Research report. UK, 2003. p.58- 63.

HESPANHOL, I. Água e saneamento básico - Uma visão realista. In: REBOUÇAS, A.C.; BRAGA, B.; TUNDISI, J.G. (Org.). Águas doces no Brasil capital ecológico, uso e conservação. São Paulo: Instituto de Estudos Avançados da USP, 1999, p.249-303.

HOLMES, T. P. The off-spite impact of soil erosion on the water treatment industry. Land Economics, v. 64, n. 4, p. 356-66, Nov. 1988.

INSTITUTO DE PESQUISAS E ESTUDOS FLORESTAIS; SERVIÇO MUNICIPAL DE ÁGUAS E ESGOTO DE PIRACICABA. A conservação dos recursos hídricos por meio da recuperação e da conservação da cobertura florestal na bacia do rio Corumbataí. Plano Diretor. Piracicaba: IPEF;ESALQ;SEMAE, 2001. 301 p.

INSTITUTO DE PESQUISAS TECNOLÓGICAS DO ESTADO DE SÃO PAULO. Mapa Geomorfológico do Estado de São Paulo. São Paulo: IPT, 1981. 2v.

INSTITUTO DE PESQUISAS TECNOLÓGICAS DO ESTADO DE SÃO PAULO. Mapa Geológico do Estado de São Paulo. São Paulo: IPT, 1981. 2v.

KARR, J. R. E DUDLEY, D.R. Ecological perspectives on water quality goals. Environmental Management, v.5, p. 55-68, 1981. 
KITTREDGE, J. Forests Influences. Chicago: McGraw-Hill, 1973. 394 p.

LANNA, A.E.L. Gerenciamento de bacia hidrográfica: aspectos conceituais e metodológicos. Brasíllia: IBAMA, 1995. 171 p.

LEE, T.R. Urban water management for better urban life in Latin America. Urban Water, v.2, n.1, p.71-78, 2000.

LIMA, W.P. A microbacia e o desenvolvimento sustentável. Ação Ambiental, v.1, n.3, p.20-22, 1999.

LIMA, W.P. Importância das florestas para produção de água. In: SIMPÓSIO SOBRE RECUPERAÇÃO DA COBERTURA FLORESTAL DA BACIA DO RIO CORUMBATAÍ, Piracicaba. Anais. Piracicaba: IPEF, 2000. p. 10-18.

LIMA, W. P. Hidrologia florestal aplicada ao manejo de bacias hidrográficas (Apostila). Piracicaba: ESALQ, 1996. 318 p.

LIMA, W.P.; ZAKIA, M. J. B. Hidrologia de matas ciliares, In: RODRIGUES, Jr.; LEITÃO FILHO, H.F. Matas ciliares: conservação e recuperação. São Paulo: EDUSP, 2000. p. 33-44.

LÓPEZ, A. A. O. Análise dos Custos Privados e Sociais da erosão do solo - o caso da bacia do rio Corumbataí, 1997. 118p. Tese (Doutorado) - Escola Superior de Agricultura "Luiz de Queiroz" - ESALQ, Universidade de São Paulo.

MCKANNA, G. World water cost survey. Arizona water resource. http://www.ag.arizona.edu/AZWATER / (18 jul. 2003).

MULLER, A.P.B. Detecção de oocistos de Cryptosporidium, spp, em águas de abastecimento superficiais e tratadas da Região Metropolitana de São Paulo, 2000. 135p. Dissertação (M.S.) - Instituto de Ciências Biomédicas, Universidade de São Paulo. 
NATIONAL RESEARCH COUNCIL; COMMITTEE TO REVIEW THE NEW YORK CITY WATERSHED MANAGEMENT STRATEGY; WATER SCIENCE AND TECHNOLOGY BOARD; COMISSION ON GEOSCIENCES, ENVIRONMENT AND RESOURCES. Watershed management for potable water supply. Assessing the New York city strategy. http:// books.nap.edu/catalog/9677.html / (24 ago. 2003).

NAVAS-PEREIRA, D. Indicadores Biológicos em ecossistemas aquáticos (Apostila). São Paulo: Faculdade de Saúde Pública da USP, 2001. 22 p.

NELSON, E.J.; BOOTH, D.B. Sediment sources in an urbanizing, mixed land-use watershed. Journal of Hydrology, v.264, n.1-4, p. 51-68, jul. 2002.

NOVOTNY, V.; OLEM, H.. Water quality: prevention, identification, and management of diffuse pollution, New York: Van Nostrand Reinhold, 1994. p. 1054.

PAGIOLA, S.; BISHOP, J.; LANDELL-MILLS, N. Selling environmental services. Earthscan, 2002. http://Inweb18.worldbank.org/ESSD/envext.nsf/80ByDocName/WBWWFForestAlliance/ (25 fev. 2004).

PROGRAMA DAS NAÇÕES UNIDAS PARA O DESENVOLVIMENTO NO BRASIL. http://www.undp.org.br/ (25 fev. 2004).

PROJETO PIRACENA. Banco de dados - geoprocessamento. Piracicaba: CENA/USP. http://www.cena.usp.br/piracena/ (20 fev. 2004).

RANDHIR, T. O.; CONNOR, R.O.; PENNER, P.R.; GOODWIN, D.W. A watershed-based land prioritization model for water suplly protection. Forest ecology and management, v.143, p.47-56, 2001.

SALATI, E.; LEMOS, H.M.. Água e o Desenvolvimento Sustentável. In: REBOUÇAS, A.C.; BRAGA, B.; TUNDISI, J.G. (Org.). Águas doces no Brasil capital ecológico, uso e conservação. São Paulo: Instituto de Estudos Avançados da USP, 1999, p.39-59.

SÃO PAULO (Estado). CONSELHO ESTADUAL DE RECURSOS HÍDRICOS. Plano estadual de recursos hídricos: primeiro plano do Estado de São Paulo. São Paulo: DAEE, 1990. 113p. 
SÃO PAULO (Estado). SECRETARIA DO MEIO AMBIENTE. Estabelecimento de metas ambientais e reenquadramento dos corpos d'água: Bacia do rio Piracicaba. São Paulo. 1994. 92p.(Relatório Técnico).

SÃO PAULO (ESTADO). SECRETARIA DO MEIO AMBIENTE. Recursos hídricos: histórico, gestão e planejamento. São Paulo. 1995. 90p.

SÃO PAULO (Estado). SECRETARIA DE RECURSOS HÍDRICOS, SANEAMENTO E OBRAS. Levantamento e sistematização de dados sobre áreas de risco, áreas degradadas, áreas sujeitas à erosão e informações específicas sobre resíduos sólidos domésticos e sobre atividades agrícolas desenvolvidas nas bacias dos rios Piracicaba, Capivari e Jundiaí. São Paulo. 1996. t.II. (Relatório Técnico).

SERVIÇO MUNICIPAL DE ÁGUAS E ESGOTO DO MUNICÍPIO DE PIRACICABA. http://www.semaepiracicaba.org.br / (28 dez. 2003).

STEIN, D.P. Diagnóstico de erosão. In: SIMPÓSIO NACIONAL DE CONTROLE DE EROSÃO, 5., Bauru, 1995. Anais. São Paulo: ABGE, 1995. p.55-57.

SWANSON, RH, RH SWANSON ; ASSOIATES, CANADA. Forest hydrology issues for the $21^{\text {st }}$ century: A consultant's viewpoint. Journal of the American water resources association, v.34, n. 4, p. $755-763,1998$.

TUNDISI, J.G.; TUNDISI, T.M.; ROCHA,O. Limnologia de águas interiores. Impactos, conservação e recuperação de ecossistemas aquáticos. In: REBOUÇAS, A.C.; BRAGA, B.; TUNDISI, J.G. (Org.). Águas doces no Brasil capital ecológico, uso e conservação. São Paulo: Instituto de Estudos Avançados da USP, 1999, p.195-225.

UNESP/IGCE/CEAPLA. Atlas ambiental da bacia do rio Corumbataí. http://www.unesp.rc.br/igce/ceapla/atlas/ (15 jun. 2004).

VIVEIROS, M. Economia desde 2001 teria evitado crise. Folha de São Paulo, São Paulo, 17 fev. 2004. p. C4.

WALTON, W.C. The world of water. New York: Taplinger Publishing, 1970. 318 p.

WANG, $X$. Integrating water-quality management and land-use planning in a watershed context. Journal of Environmental Management, v.61, p.25-36, 2001. 
WWF/THE WORLD BANK - ALLIANCE FOR FOREST CONSERVATION AND SUSTAINABLE USE.; IUCN. The importance of forest protected areas to drinking water. (Reseach report). http://worldwildlife.org/news/displayPR.cfm?prID=59/ (25 fev. 2004).

WORLD METEOROLOGY ORGANIZATION . Weather Climate Water in the information age, n. 970, p.22. 2004.

ZAVATINI, J.A.; CANO, H. Variações do ritmo pluvial na bacia do rio Corumbataí - SP. Boletim de Geografia Teorética, n.23, p.215-240. 1993. 
A P ÊN DICES 


\section{Legislação Federal relacionada ao gerenciamento de bacias Hidrográficas de abastecimento público}

No Brasil, o exercício do gerenciamento de bacias hidrográficas deve observar legislações nos diversos segmentos técnicos de atuação (controle de poluição, uso e ocupação do solo, setor florestal, vigilância sanitária, etc.).

A preservação de mananciais de abastecimento público é um desafio a ser encarado pela atual geração, que assiste à degradação acelerada de mananciais consagrados de abastecimento, devido aos efeitos ambientais indesejáveis decorrentes do desenvolvimento econômico sem critérios e do uso e ocupação do solo inadequados. Por se tratar de tema tão complexo, a discussão da preservação de mananciais de abastecimento público necessariamente permeia diversas esferas políticas, administrativas e sociais, bem como legislação pertinente a vários segmentos. Serão assim apenas relacionadas com breves comentários leis, decretos, resoluções e marcos importantes, associados com a gestão de recursos hídricos e seu viés relacionado à preservação de mananciais para o abastecimento público.

\section{Código Florestal - 1965}

A Lei № 4.771, de 15 de Setembro de 1965 - (D.O.U. DE 16/09/65) instituiu o Novo Código Florestal.

O Código Florestal é legislação de extrema importância, principalmente no que se refere à proteção (áreas de preservação permanente) das áreas florestais, que se encontram em algumas regiões da paisagem como, por exemplo, ao redor das nascentes $(50 \mathrm{~m})$ e ao longo dos cursos d'água (faixas de preservação variam de acordo com a largura do corpo d'água), conforme seu 
Artigo 20. Algumas dessas áreas florestais que devem ser protegidas (ex: nascentes) têm importância fundamental na

produção de água em qualidade e quantidade. Contudo, essas áreas, que são consideradas extremamente sensíveis numa microbacia, não estavam protegidas quando não se encontravam cobertas por vegetação

\section{Política Nacional do Meio Ambiente, com a criação do Conselho Nacional do Meio Ambiente (CONAMA )de 1981}

Em 1981 é sancionada a Lei Nacional do Meio Ambiente, Lei Federal n. ${ }^{\circ}$ 6938/81, definindo pela primeira vez uma base legal específica para o meio ambiente e também prevendo a formação de um sistema de proteção ambiental e do Conselho Nacional do Meio Ambiente ( CONAMA ), incluindo a participação da sociedade civil. Esta Lei é considerada avançada para o seu tempo, trazendo o conceito de meio ambiente como fundamental ao planejamento de uma ação integrada entre os diversos órgãos governamentais, segundo uma Política Nacional de Meio Ambiente.

Como instrumento de política de meio ambiente foram propostos o estabelecimento de padrões de qualidade ambiental, o zoneamento ambiental, a avaliação de impactos ambientais, o licenciamento e a revisão de atividade efetiva ou potencialmente poluidora, os incentivos à produção e instalação de equipamentos e a criação ou absorção de tecnologias voltadas para a melhoria da qualidade ambiental, a criação de estados ecológicos e áreas de proteção ambiental, sistema nacional de informações sobre o ambiente, cadastro técnico federal das atividades e instrumentos de defesa ambiental e penalidades disciplinares ou compensatórias ao não cumprimento das medidas necessárias à preservação ou correção da degradação ambiental, AQUINO(1998).

\section{Resolução CONAMA n. ${ }^{\circ}$ 01, de 1986}

Esta resolução dispõe sobre as diretrizes gerais para uso e implementação da Avaliação de Impacto Ambiental. A resolução considera impacto 
ambiental como qualquer alteração das propriedades físicas, químicas e biológicas do meio ambiente, causado por qualquer forma de matéria ou energia resultante das atividades humanas que direta ou indiretamente afetem: a saúde, a segurança e o bem estar da população; as atividades sociais e econômicas; a biota; as condições estéticas e sanitárias do meio ambiente e a qualidade dos recursos ambientais.

A resolução estabelece a necessidade de elaboração de Estudo de Impacto Ambiental e respectivo relatório de Impacto Ambiental e necessidade de sua submissão à aprovação do órgão estadual ambiental competente.

Esta resolução garante a submissão da aprovação dos empreendimentos à consulta à sociedade civil, em audiência pública.

A importância desta resolução à preservação do meio ambiente é inquestionável. Entretanto, a interferência política nas decisões estaduais referentes ao licenciamento de empreendimentos pode ser encontrada com frequência.

\section{Resolução CONAMA n. ${ }^{\circ}$ 20, de 1986}

Com relação aos recursos hídricos o CONAMA através da Resolução n. ${ }^{\circ}$ 20, de 18/06/86, classificou as águas de todo o território nacional, com enfoque sobre a qualidade, visando o planejamento de seu uso, cabendo aos Estados realizarem seus enquadramentos. O Estado de São Paulo associou suas classes estabelecidas pelo Decreto 8468/76 às estabelecidas na Resolução CONAMA n. ${ }^{\circ} 20$, observando os principais usos. Em 1986 surgiu a primeira proposta de um Sistema Nacional de Gerenciamento de Recursos Hídricos, vindo a ser aprovada somente em 1997, com a Lei Federal 9433 que instituiu a Política Nacional de Recursos Hídricos e criou o Sistema mencionado.

\section{Constituição Federal de 1988}

Quando se analisa o histórico das Constituições Federais observa-se o registro do processo gradativo de centralização das competências jurídicas relativas à água ao nível da União. A Constituição de 1946 regulamentava a utilização de recursos naturais visando a sua exploração econômica. No entanto, permitia aos Estados 
legislar sobre o tema supletiva e complementarmente à União. Na Constituição de 1967 foi reforçado o aspecto da exploração econômica e estabelecidas regras genéricas sobre o uso da água.

Na Constituição Federal de 1988 foi previsto um Sistema Nacional de Recursos Hídricos, porém, diferindo da previsão, a Constituição não evoluiu nesta área. A legislação regulamentadora desse sistema só foi aprovada em 1997.

\section{Ministério do Meio Ambiente, criado em 1992}

Em 1992 é criado o Ministério do Meio Ambiente, que em 1995 foi intitulado Ministério do Meio Ambiente, dos Recursos Hídricos e da Amazônia Legal. Sua competência recai sobre o exercício de ações de planejamento e controle do meio ambiente e recursos hídricos, a formulação da Política Nacional de Meio Ambiente, a preservação e conservação dos recursos naturais e a implementação de acordos na área ambiental.

\section{Política Nacional de Recursos Hídricos, criando o Sistema Nacional de Gerenciamento dos Recursos Hídricos, 1997}

Em 1997 foi sancionada a Lei Federal n. 9433 que institui a Política Nacional de Recursos Hídricos, criando o Sistema Nacional de Gerenciamento dos Recursos Hídricos. Esta lei tem estrutura muito parecida com a Lei Paulista Estadual 7663/91, garantindo também a participação tripartite, Estado, Municípios e Usuários. Em junho de 1998 o Decreto Federal 2612 regulamenta o Conselho Nacional de Recursos Hídricos, criado pela Lei Federal 9433/97. Esta legislação institui a criação de Comitês de bacias federais, para gerenciamento das bacias hidrográficas federais e possui os seguintes princípios básicos: a) da bacia hidrográfica como unidade de planejamento; b) dos usos múltiplos da água; c) do reconhecimento da água como um bem finito e vulnerável; d) do reconhecimento do valor econômico da água, que serve de base para a instituição da cobrança pelo uso da água; e) da gestão descentralizada e participativa(envolvimento dos usuários no processo de tomada de decisão). 


\section{Lei de Crimes Ambientais - Lei Federal nº 9.605 - 1998}

Esta Lei federal que dispõe sobre as sanções penais e administrativas derivadas de condutas e atividades lesivas ao meio ambiente, e dá outras providências.

A Lei de Crimes Ambientais fortaleceu a atuação de órgãos de fiscalização dos recursos naturais, estaduais e federais. A possibilidade de indiciar um indivíduo ou empresa por crime ambiental, com a possibilidade de aplicação de penas severas, deu credibilidade ao agente fiscalizador e gravidade às intervenções nocivas ao meio ambiente.

\section{Agência Nacional das Águas - ANA, Lei Federal n 9.984, 2000}

A Lei estabelece a criação da Agência Nacional das Águas, entidade federal que será responsável pela implementação da Política Nacional de Recursos Hídricos e pela coordenação do Sistema nacional de gerenciamento de Recursos Hídricos.

Objetivamente, a Agência possibilita a cobrança pelo uso da água e o repasse de parte do recurso para as bacias hidrográficas de origem.

A Agência, apesar de ter sido implementada de forma centralizadora, foi efetivada e deverá gerar recursos para a recuperação de bacias hidrográficas, visando a melhoria da qualidade de seus corpos de água.

\section{Revisão do Código Florestal - Resolução CONAMA n 302 - 2002}

Dispõe sobre parâmetros, definições e limites de Áreas de Preservação Permanente. Essa resolução foi criada, considerando-se a necessidade de regulamentar o art. $2^{\circ}$ da Lei $n^{\circ} 4.771$, de 15 de setembro de 1965, no que concerne às Áreas de Preservação Permanente. Ela considerou as responsabilidades assumidas pelo Brasil por força da Convenção da Biodiversidade, de 1992, da Convenção Ramsar, de 1971 e da Convenção de Washington, de 1940, bem como os compromissos derivados da Declaração do Rio de Janeiro, de 1992 e que as Áreas de Preservação Permanente e outros espaços territoriais especialmente protegidos, são 
instrumentos de relevante interesse ambiental, integram o desenvolvimento sustentável e são objetivo das presentes e futuras gerações.

Com a resolução CONAMA N ${ }^{0} 302$ passam a ser protegidas (áreas de preservação permanente) algumas áreas da paisagem como, por exemplo, o entorno das nascentes $(50 \mathrm{~m})$ e ao longo dos cursos d'água (faixas de preservação variam de acordo com a largura do corpo d'água), mesmo que essas não estejam cobertas por florestas. 